\title{
TECHNICAL REPORT E-73-1
}

\section{PROJECT TRINIDAD}

EXPLOSIVE EXCAVATION TESTS IN SANDSTONE AND SHALE

U.S. Army Engineer Waterways Experiment Station

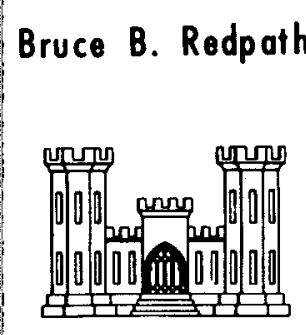

July 1972

Explosive Excavation Research Laboratory

THIS DOCUMENT CONFIRMED/AS DIVISION OF CLASSIFICATION

BY I.L.Cuc chionafwer DATEB/2L/173

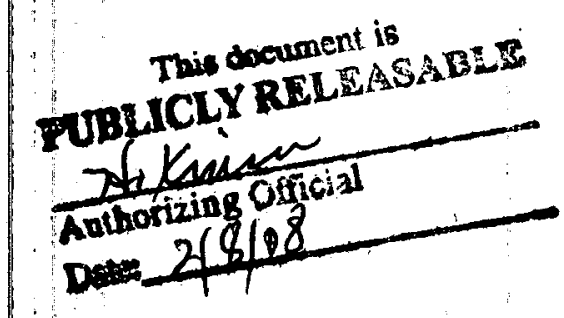

93228

Approved for public release; distribution unlimited 



\section{TECHNICAL REPORT E-73-1 \\ PROJECT TRINIDAD \\ EXPLOSIVE EXCAVATION TESTS IN \\ SANDSTONE AND SHALE}

BRUCE B. REDPATH

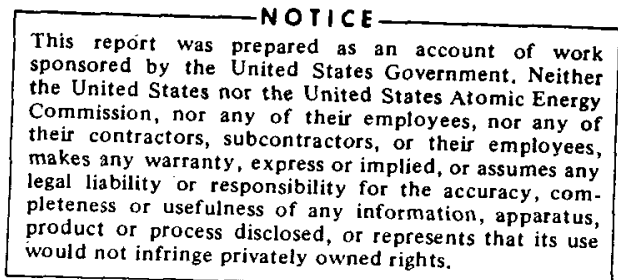

This report was prepared as an account of work

sponsored by the United States Government. Neither

the United States nor the United States Atomic Energy

Commission, nor any of their employees, nor any of

would not infringe privately owned rights.

Conducted by

U.S. ARMY ENGINEER WATERWAYS EXPERIMENT STATION

EXPLOSIVE EXCAVATION RESEARCH LABORATORY

LIVERMORE, CALIFORNIA

MS. date: July 1972 


\section{Foreword}

The Explosive Excavation Research Laboratory (EERL) ${ }^{*}$ is embarked on a program of research in topical areas critical to the overall technology that is referred to as "explosive excavation." This is the report of a complete program of explosive excavation experiments, and includes summaries of the related technical programs such as seismic effects, airblast generation, and engineering properties of a large crater excavated for a railway cut. The report is primarily oriented towards the cratering aspects of the program, for indeed, the acquisition of the cratering characteristics of a weak rock and the verification of row-charge design rules were the principal goals in conducting the experiments. The excavation of a railway cut at the conclusion of the project was a successful demonstration of the economic benefits of explosive excavation. Two additional railway cuts later excavated in the same area represented immediate and beneficial applications of the knowledge acquired during the project, and this same knowledge will continue to contribute to the mission of EERL.

\footnotetext{
"The U.S. Army Engineer Waterways Experiment Station (USAEWES) Explosive Excavation Research Laboratory (EERL) was the USAEWES Explosive Excavation Research Office (EERO) from 1 August 1971 to 21 April 1972. Prior to that time, it was known as the USAE Nuclear Cratering Group (NCG).
} 


\begin{abstract}
A series of single-, row-, and multiple-charge cratering detonations, with individual charge weights of 1 to 2 tons, were carried out in weak, interbedded sandstones and shales near Trinidad, Colorado, in 1970 and 1971 . The principal objectives of these excavation experiments were to obtain single-charge cratering curves, to verify row-charge designs for achieving a specified excavation, to determine the effects of millisecond delays in row-charge cratering, to experiment with cratering in varying terrain, and to compare the cratering effectiveness of several explosives. Three varieties of aluminized ammonium-nitrate blasting agents and ANFO were used. Airblast and seismic effects of each detonation were monitored. The series culminated with the excavation of a railway cut $400 \mathrm{ft}$ long with 44 tons of explosives distributed among
\end{abstract} 32 charges. 


\section{Acknowledgments}

This report is the outcome of the efforts of many people involved in Project Trinidad. LT Terry Shackleford wrote Chapter 2 and, together with MAJ Charles Gardner, also wrote Chapter 6; LT Dale McWilliams contributed significantly to Chapter 4; and Charles Snell prepared Chapter 5. MAJ Richard Gillespie was Test Director. All of the people above were responsible for the successful conduct of their respective technical programs in the field, and to them is due the credit for the overall success of the project. COL William E. Vandenberg, LTC Robert L. LaFrenz, and LTC Robert R. Mills, Jr. were Directors of EERL during the course of the field work and the preparation of this report. 


\section{Contents}

FOREWORD

ABSTRACT

ACKNOW LEDGMENTS

CONVERSION FACTORS

CHAPTER 1. INTRODUCTION

General

Background and Objectives

Scope of Program

Project Organization

CHAPTER 2. SITE DESCRIPTION

Location and Topography

Geology

Preshot Engineering Properties of Site Medium $\quad$. . . . . . . . . . $\quad$. 6

CHAPTER 3. CRATER MEASUREMENTS

B-Series

C-Series

Simultaneous Rows (C1, C2, C3)

Delayed Row-Charges (C4, C5)

Double Row-Charge Detonation (C6)

D-Series

Single Row-Charge through Varying Terrain (D1)

Single Row-Charge along a Sidehill (D2)

Double Row-Charge along a Sidehill (D3)

Delayed Double Row-Charge (Railway Cut, D4)

CHAPTER 4. SEISMIC MEASUREMENTS

Scope

Results

CHAPTER 5. AIRBLAST MEASUREMENTS

Scope

Results

CHAPTER 6. ENGINEERING STUDIES OF D4 CRATER

Introduction

On-Site Investigative Programs

Mass Density and Bulking Facto

Field Determination of Particle Gradation

Drilling, Coring, and Borehole Photography

Shaping of Railroad Cut

Fallback Compaction and Field Settlement Study

ii

iii

iv

$\mathrm{x}$

1

1

1

2

4

4

4

5

7

8

- 12

- 13

17

17

- 18

- 18

- 23

- 25

- 27

32

32

35

- 36

36

- 37

- 39

- 39

- 39

39

39

40

41

42 
CHAPTER 7. CONCLUSIONS

APPENDIX A DRILL HOLE LOCATIONS, STRATIGRAPHY

AND LITHOLOGY, AND MATERIAL PROPERTIES DATA

APPENDIX B CRATER PROFILES AND CROSS SECTIONS

47

APPENDIX C

SEISMIC DATA

APPENDIX D

AIRBLAST DATA

APPENDIX E

LABORATORY TESTING OF FALLBACK MATERIAL

REFERENCES

FIGURES

1. Organization of Project Trinidad

2. Project Trinidad site location

3. Generalized stratigraphic section of Trinidad,

Vermejo, and Raton formations

4. Engineering classification for intact rock

5. Aerial view of principal experimental area showing $B$ series, C series, and D4 crater

6. Bucket auger used to emplace charges

7. Typical 1-ton single-charge crater

8. Apparent crater radii and depths for $B$ series

9. Volumes of B series apparent craters

10. C3 row crater

11. Row crater enhancement vs charge spacing

12. Single-charge cratering curves with row crater dimensions superimposed

13. Longitudinal profiles, charge layout, and cross sections of C6 crater

14. D1 preshot terrain, charge layout, cross sections, and crater profile

15. D1 crater

16. Longitudinal profiles and cross sections of D2 crater

17. D2 crater

18. Longitudinal profiles and cross sections of D3 crater

19. D3 crater

20. Anticipated cross section and plan view of D4 experiment

21. Chart of charge spacing vs depth of cut for 1 - and 2-ton charges of TD-2 slurry in sandstone and shale

22. D4 detonation

23. D4 crater viewed from west to east along center

line of railroad

24. Cross sections of D4 railway cut showing comparison between crater and cut excavated by conventional methods . . . 31

25. Locations of seismic monitoring stations during Project Trinidad

26. Peak ground motion amplitudes vs distance

27. Peak airblast overpressures for selected

Project Trinidad detonations

$$
-v i-
$$


28. Map of D4 crater showing location of postshot

engineering investigations

29. Location of core holes in D4 crater and extent of blast-induced fracturing (cross section through Station 93+00) . . 41

30. Dozer daylighting end of cut and bringing cut to grade $\ldots$. . . . . 41

31. Dozer scales crater slopes; front loader removes material from crater

32. Finished cut

33. Settlement markers

34. Layout of settlement markers for vibratory compaction tests . . . 43

35. Bros smooth-roller vibratory compactor . . . . . . . . . . 43

36. Surface settlement produced by vibratory compaction tests . . . . 44

A1. Map showing location of core holes for B and C

series and D4 railroad cut . . . . . . . . . . . . . . 47

A2. Map showing location of emplacement and core holes for Experiment D1, D2, and D3 . . . . . . . . . . 48

A3. Stratigraphy and lithology of B series . . . . . . . . . 49

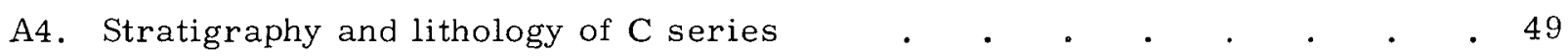

A5. Stratigraphy and lithology of Experiments D1, D2, and D3 . . . . 50

A6. Stratigraphy and lithology of D4 railroad cut . . . . . . . . 50

B1. Crater nomenclature . . . . . . . . . . . . . . . 54

B2. Cross sections of craters B1 and B2 . . . . . . . . . . . . . . 55

B3. Cross sections of Craters B3 and B4 . . . . . . . . . . . . 56

B4. Cross sections of Craters B5 and B6 . . . . . . . . . . . . . . $\quad . \quad 57$

B5. Cross sections of Craters B7 and B8 . . . . . . . . . . . . 58

\begin{tabular}{l} 
B6. Longitudinal profiles and representative cross sections \\
for Rows $\mathrm{C} 1$ and $\mathrm{C} 2$. \\
\hline
\end{tabular}

\begin{tabular}{c} 
B7. Longitudinal profiles and representative cross sections \\
for Row $\mathrm{C} 3$. \\
\hline
\end{tabular}

\begin{tabular}{c} 
B8. Longitudinal profiles and representative cross sections \\
for Rows $\mathrm{C} 4$ and $\mathrm{C} 5$. \\
\hline
\end{tabular}

D1. Observed single-charge transmission factors as a function of scaled depth of burst for aluminized ammonium nitrate slurry detonations, Project Trinidad . . . . . . . . 72

E1. Comparison of grain-size distribution curves determined by point count technique and by sieving . . . . . . . $\quad . \quad 79$

E2. Grain-size distribution curves for material as received and for test specimens . . . . . . . . . . . . 80

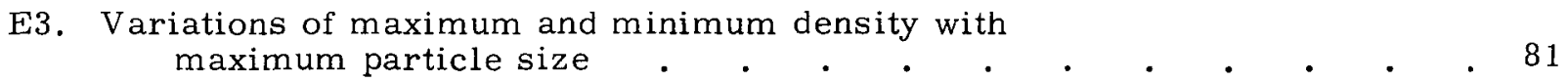

E4. Wet specimen (36-in. diameter) after testing . . . . . . . . 82

E5. Stress-strain and volume change curves for specimens compacted to $71 \%$ relative density (confining pressure, $15 \mathrm{psi}$ )

E6. Stress-strain and volume change curves for specimens compacted to $71 \%$ relative density (confining pressure, $30 \mathrm{psi}$ ) 
E7. Stress-strain and volume change curves for specimens compacted to $77 \%$ relative density (confining pressure, $15 \mathrm{psi}$ )

E8. Stress-strain and volume change curves for specimens compacted to $77 \%$ relative density (confining pressure, $30 \mathrm{psi}$ )

E9. Stress-strain and volume change curves for specimens compacted to $73 \%$ relative density (confining pressure, 15, psi)

E10. Stress-strain and volume change curves for specimens compacted to $73 \%$ relative density (confining pressure, $30, \mathrm{psi}$ )

E11. Stress-strain and volume change curves for specimens compacted to three relative densities (confining pressure, $15 \mathrm{psi}$ )

E12. Stress-strain and volume change curves for specimens compacted to three relative densities (confining pressure, $30 \mathrm{psi}$ )

E13. Compression time curves for specimens compacted to $80 \%$ relative density

E14. One-dimensional compression curves for specimens compacted to $80 \%$ relative density

E15. One-dimensional compression curves for specimens compacted to $50 \%$ relative density

E16. Variations of angle of internal friction with relative density

E17. Variation of volumetric strain due to wetting with maximum particle size

E18. Variation of compression due to wetting with ariation of compression due to wetting with
overburden pressure for at-rest pressure conditions

\section{TABLES}

1. Summary of Project Trinidad cratering experiments

2. B-series cratering charges

3. Characteristics of Project Trinidad explosives

4. B-series crater dimensions

5. C-series charge emplacement

6. Summary of row crater dimensions

7. Unit volumes for $\mathrm{C}$-series row craters

8. Summary of D-series experiments

9. D1, D2, D3 charge emplacement

10. D4 charge emplacement summary

11. Locations of seismic recorders, Project Trinidad . • • . • . 33

12. Airblast damage criteria

A1. Results of tests of B-series rock cores

A2. Results of tests of $\mathrm{C}$-series rock cores

A3. Results of tests of D-series rock cores 
C1. Maximum recorded particle velocities for B-series

C2. Maximum recorded particle velocities for $\mathrm{C} 1, \mathrm{C} 2, \mathrm{C} 33 \ldots$

C3. Maximum recorded particle velocities for $\mathrm{C} 4, \mathrm{C} 5, \mathrm{C} 6$. . . . . . 63

C4. Maximum recorded particle velocities for D-series . . . . . . . 64

D1. Close-in airblast observations for Detonations B1 through B8 (single-charges). Altitude $\simeq 6200 \mathrm{ft}$ AMSL; ambient pressure $\simeq 810 \mathrm{mbar}$

$\mathrm{D} 2 \mathrm{a}$. Close-in airblast observations for Detonations $\mathrm{C} 1$ and $\mathrm{C} 2$ (row-charges). Altitude $=6200 \mathrm{ft}$ AMSL; ambient pressure $\approx 810 \mathrm{mbar}$

$\mathrm{D} 2 \mathrm{~b}$. Close-in airblast observations for Detonations $\mathrm{C} 3$ and $\mathrm{C} 4$ (row-charges). Altitude $\simeq 6200 \mathrm{ft}$ AMSL; ambient pressure $\simeq 810 \mathrm{mbar}$

D2c. Close-in airblast observations for Detonations C5 and C6 (row-charges). Altitude $\simeq 6200 \mathrm{ft}$ AMSL; ambient pressure $\simeq 810 \mathrm{mbar}$

D3. Close-in airblast observations for Detonations D1 through D3 (row-charges). Altitude $\simeq 6200 \mathrm{ft}$ AMSL; ambient pressure $\simeq 810 \mathrm{mbar}$

D4. Close-in airblast observations for Detonation D4 (row-charges). Altitude $\simeq 6200 \mathrm{ft}$ AMSL; ambient pressure $\simeq 810 \mathrm{mbar}$

D5a. Ground-shock-induced overpressure reinforcement correction factors for Trinidad row-charge detonations $. \quad \cdot \quad \cdot \quad . \quad$. $\quad 73$

D5b. Gas-vent-induced overpressure reinforcement correction factors for Trinidad row-charge detonations . .

D6. Airblast amplitudes for row-charges expressed in terms of single-charge airblast amplitudes

E1. Composition and specific gravities of various sized fractions of Trinidad fallback

E2. Values of particle breakage factor B determined by resieving triaxial specimens after testing

E3. Summary of triaxial test results

E4. Surface settlements due to groundwater rise within $5 \mathrm{ft}$ of ground surface for various fallback layer thicknesses 


\section{Conversion Factors}

British units of measurement used in this report can be converted to metric units as follows:

\begin{tabular}{lll}
\hline \multicolumn{1}{c}{ Multiply } & \multicolumn{1}{c}{ By } & \multicolumn{1}{c}{ To Obtain } \\
\hline inches & 2.54 & centimeters \\
feet & 0.3048 & meters \\
cubic feet & 0.02832 & cubic meters \\
cubic yards & 0.764555 & cubic meters \\
pounds & 0.4535924 & kilograms \\
pounds per square inch & 0.00689476 & meganewtons per square meter \\
pounds per cubic foot & 16.02 & kilograms per cubic meter \\
Fahrenheit degrees & $5 / 9$ & Celsius or Kelvin degrees \\
foot-pounds & 0.138255 & meter-kilograms \\
\hline
\end{tabular}

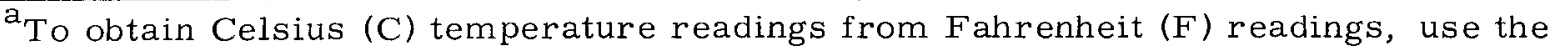
following formula: $\mathrm{C}=(5 / 9)(\mathrm{F}-32)$. To obtain Kelvin $(\mathrm{K})$ readings, use: $\mathrm{K}=(5 / 9)$ $(\mathrm{F}-32)+273.15$.
} 


\section{TECHNICAL REPORT E-73-1 \\ PROJECT TRINIDAD \\ EXPLOSIVE EXCAVATION TESTS \\ IN SANDSTONE AND SHALE}

\section{Chapter 1. Introduction}

GENERAL

This report is a technical summary of the results of an extensive series of excavation experiments conducted in interbedded sandstones and shales near Trinidad, Colorado. The experimental program progressed from single-charge craters through row-charge craters to multiple row-charge detonations. The individual charge weights were of the order of 1 ton, and a variety of explosives were used. Project Trinidad was conducted by the U.S. Army Corps of Engineers Waterways Experiment Station Explosive Excavation Research Laboratory (EERL). At the time of the experiments, in the summer and fall of 1970, the organization was known as The Nuclear Cratering Group (NCG). The Nuclear Cratering Group was organized in 1962 to engage in a joint venture with the $A E C$ to investigate peaceful excavation applications of nuclear explosives.

\section{BACKGROUND AND OBJECTIVES}

All of the early cratering experiments performed by EERL were designed as chemical-explosive "models" of nuclear experiments. As research under the joint Atomic Energy Commission-Corps of Engineers program progressed, exca- vation with large chemical-explosive charges appeared to have several potential merits in itself, and the emphasis in the experimental program gradually shifted to investigating the use of more economical explosives and methods of emplacement.

Project Trinidad was a relatively complete program of experimental tests, the objectives of which were to investigate both the fundamentals of cratering and the economic aspects of explosive excavation. The series culminated in the successful completion of an actual railroad cut for the relocation of the Colorado and Wyoming Railroad.

The site was selected because of two factors. The cratering characteristics of the interbedded sandstones and shales were unknown and would represent a valuable contribution to cratering technology. Also, it is the policy of EERL to carry out its research activities at the locations of approved Corps of Engineers Civil Works projects whenever possible. A rockfill dam on the Purgatoire River is scheduled for construction near the town of Trinidad, and it was believed that some of the information acquired in the cratering experiments might find application to associated projects. This was indeed the case; two additional railway cuts were excavated during the preparation of this report. 
This report covers only the initial experimental work performed at Trinidad, including the first railway cut. A considerable amount of additional cratering experimentation was performed during late 1970 and through 1971. Included in these later experiments were Project Middle Course I, ${ }^{1}$ Project Minimound, ${ }^{2}$ and Project Middle Course II. ${ }^{3}$ The last two railway cuts, designated RR2 and RR3, are also the topic of a separate report. ${ }^{4}$

\section{SCOPE OF PROGRAM}

It will be helpful to the reader to briefly outline the scope of the cratering experiments and associated technical programs covered by this report.

Table 1 shows a summary and sequence of the cratering detonations of this project. The A-series consisted of attempts to create emplacement cavities for explosives by means of hole springing. The initial results did not warrant employment of this technique for any of the cratering shots, and the results of this series have been documented in a separate report. 5

The B-series consisted of eight single 1-ton cratering blasts, three using ANFO (ammonium nitrate and fuel oil) and five using an aluminized slurry blasting agent.

Table 1. Summary of Project Trinidad cratering experiments.

\begin{tabular}{|c|c|c|c|}
\hline Series & Number & Craters, charges, and explosive & Date \\
\hline$A^{a}$ & - & - & - \\
\hline \multirow[t]{2}{*}{$\mathrm{B}$} & $\mathrm{B} 1-\mathrm{B} 3$ & Three 1 -ton single-charge craters using ANFO & \multirow{2}{*}{$\begin{array}{l}\text { July and August } \\
1970\end{array}$} \\
\hline & $\mathrm{B} 4-\mathrm{B} 8$ & $\begin{array}{l}\text { Five } 1 \text {-ton single-charge craters using aluminized } \\
\text { slurry. }\end{array}$ & \\
\hline \multirow[t]{3}{*}{$\mathrm{C}$} & $\mathrm{C} 1-\mathrm{C} 3$ & $\begin{array}{l}\text { Three row-charge craters using five to seven } \\
1 \text {-ton charges of aluminized slurry; simultaneous } \\
\text { detonation. }\end{array}$ & \multirow{3}{*}{$\begin{array}{l}\text { September } \\
\text { and } \\
\text { October } \\
1970\end{array}$} \\
\hline & $\mathrm{C} 4-\mathrm{C} 5$ & $\begin{array}{l}\text { Two row-charge craters using five } 1 \text {-ton charges } \\
\text { of aluminized slurry; delayed detonation. }\end{array}$ & \\
\hline & C6 & $\begin{array}{l}\text { Two parallel row-charges of five } 1 \text {-ton charges } \\
\text { of aluminized slurry each; both detonated } \\
\text { simultaneously. }\end{array}$ & \\
\hline \multirow[t]{4}{*}{$\mathrm{D}$} & $\mathrm{D} 1$ & $\begin{array}{l}\text { Row-charge crater through a ridge; nine charges } \\
\text { of } 200 \text { to } 2000 \mathrm{lb} \text { ANFO. }\end{array}$ & \multirow{3}{*}{$\begin{array}{l}\text { November } \\
1970\end{array}$} \\
\hline & $\mathrm{D} 2$ & $\begin{array}{l}\text { Row-charge crater along sidehill; five } 1 \text {-ton } \\
\text { charges of slurry. }\end{array}$ & \\
\hline & D3 & $\begin{array}{l}\text { Double row-charge crater along sidehill; six } \\
1 \text {-ton and six } 2 \text {-ton charges of aluminized } \\
\text { slurry. }\end{array}$ & \\
\hline & D4 & $\begin{array}{l}\text { Double row-charge railway cut; twenty } 1 \text {-ton } \\
\text { and twelve } 2 \text {-ton charges of aluminized slurry, } \\
\text { time delay between rows. }\end{array}$ & $\begin{array}{c}\text { December } \\
1970\end{array}$ \\
\hline
\end{tabular}

\footnotetext{
${ }^{a}$ Hole springing experiments performed intermittently throughout project; topic of separate report. 5
} 
These single-charge cratering tests were intended to determine optimum burial depths; i.e., to "calibrate" the rock with regard to its cratering characteristics, so that subsequent row-charge detonations could be designed. Further, the B-series was to provide a comparison of the cratering effectiveness of the ANFO with the slurry, and to provide single-charge airblast and seismic data with which the corresponding effects of row-charges could be compared.

The six detonations in the $\mathrm{C}$-series consisted of a variety of row-charges. Three rows were a test of row-charge design procedures, two rows tested the consequences of introducing millisecond delays between charges in a row, and the last was the simultaneous detonation of two parallel row-charges. Much of the cratering information gathered during these tests was of value in designing the next series of experiments.

There were four detonations in the final phase of the program-the D-series. These experiments had a more practical aspect to them than the preceding tests. The D-series investigated the feasibility of explosively excavating cuts through varying terrain and long side-slopes. The final experiment, D4, was the excavation of a railroad cut $400 \mathrm{ft}$ in length with a delayed, double row of charges.

Seismic measurements (ground motion), airblast observations, and technical photography were an integral part of the

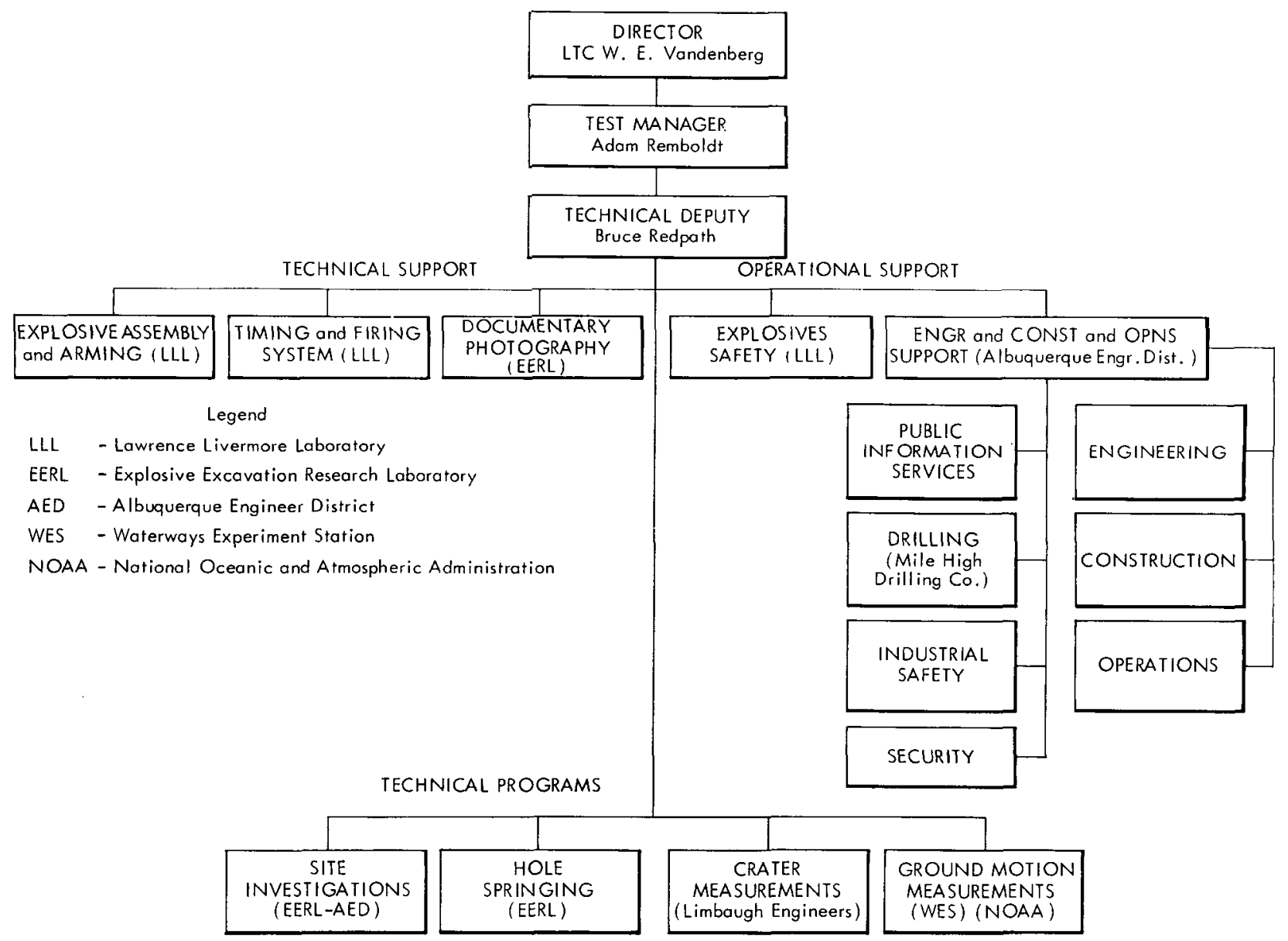

Fig. 1. Organization of Project Trinidad. 
program. The results of the major technical programs are discussed in separate chapters.

The seismic and airblast studies were oriented primarily towards comparisons of effects from the large variety of detonations, rather than towards site calibration and legal documentation, although this facet of the program was also important. Because the Government had acquired virtually all of the surrounding structures and because they were unoccupied, it was actually hoped that some damage would be caused, and therefore several of the close-in structures were monitored for potential damage resulting from the larger detonations.

\section{PROJECT ORGANIZATION}

The participating agencies and their functional relationship to the project are shown in Fig. 1. In EERL experiments, operational support is provided by the Army Engineer District having jurisdiction in the geographical area in which experiments are conducted. Drilling and explosives services are acquired by competitive bid.

\section{Chapter 2. Site Description}

\section{LOCATION AND TOPOGRAPHY}

Project Trinidad was located on the highly dissected uplands of the western Great Plains, about $6 \mathrm{mi}$ west of Trinidad, Colorado (Fig. 2). The region is flanked on the west by the majestic Sangre de Cristo Mountains, on the north by the twin spires of the Spanish Peaks, and on the east by the Great Plains. The Purgatoire River and its tributaries have broken the area into a series of flattopped mesas bounded by steep-walled, narrow valleys. The test areas were located on the flat benches and gentle sidehills that border the Purgatoire River.

The entire Trinidad site area was located within the boundary of the Trinidad Lake Project, a Corps of Engineers Civil Works program under the Albuquerque District of the Corps of Engineers. The proposed dam will help to develop the Trinidad area as a recreational and agricultural center for southern Colorado.

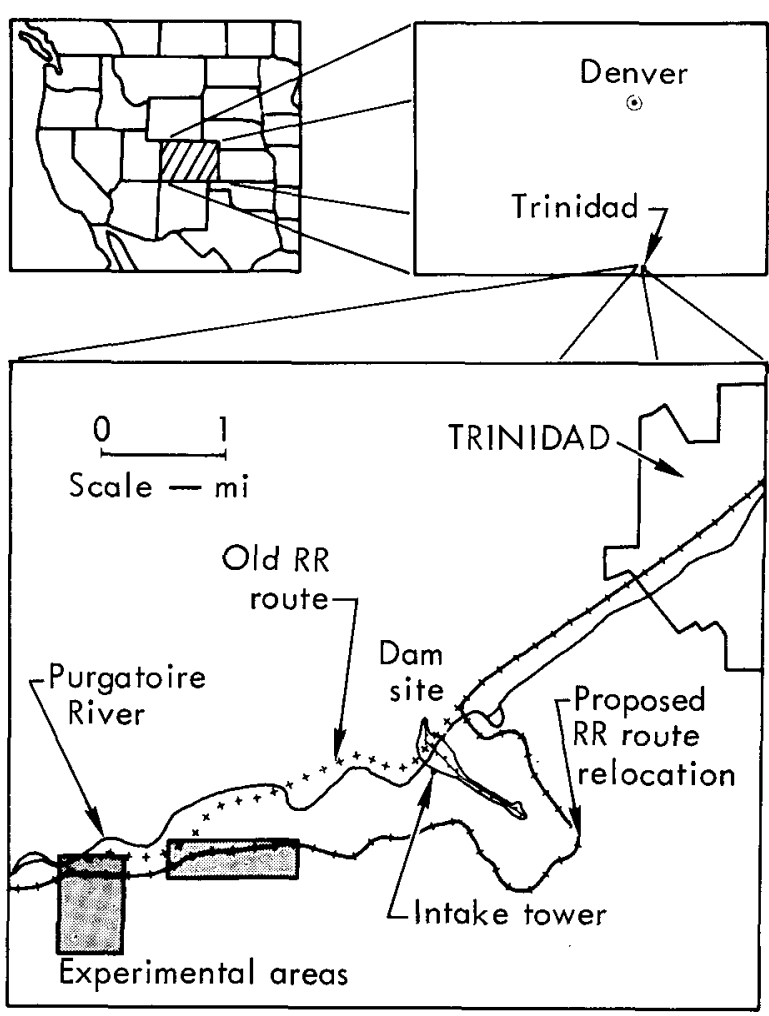

Fig. 2. Project Trinidad site location. 
The regional climate is semiarid, with most of the precipitation occurring in the summer as thundershowers. Winters are relatively mild with intermittent heavy snowfalls. Average precipitation is $14 \mathrm{in}$. while the average temperature is about $51^{\circ} \mathrm{F}$. The semiarid climate has given rise to a distinctive flora. The dominant trees are juniper, piñon, and scrub oak. Grasses are abundant throughout the area, and several species of cactus thrive.

The test area lies at the center of the once-bustling Trinidad coal field. Coal mining was the life-blood of the area until disastrous strikes and fires gradually closed down the mines. A significant decrease in population has accompanied the decline in coal production. Ruins of once-prosperous mining towns attest to this decline, and the raising of livestock has replaced coal mining as the most important industry in the area. Only the Allen mine, located in the upper valley of the Purgatoire $30 \mathrm{mi}$ west of Trinidad, is still active. Trinidad, with about 9,000 inhabitants, is the major population center of the region.

\section{GEOLOGY}

The uplands of the Trinidad area consist of sedimentary rocks of Late Cretaceous to Early Tertiary age. The surface rocks are relatively undeformed and dip gently westward forming the Raton basin. The exposed rocks consist of about $5,000 \mathrm{ft}$ of sediments, three units of which are relevant to the project: the Trinidad sandstone, the Vermejo formation, and the Raton formation. These rocks form the predominant outcrops in the test area. Figure 3 is a generalized

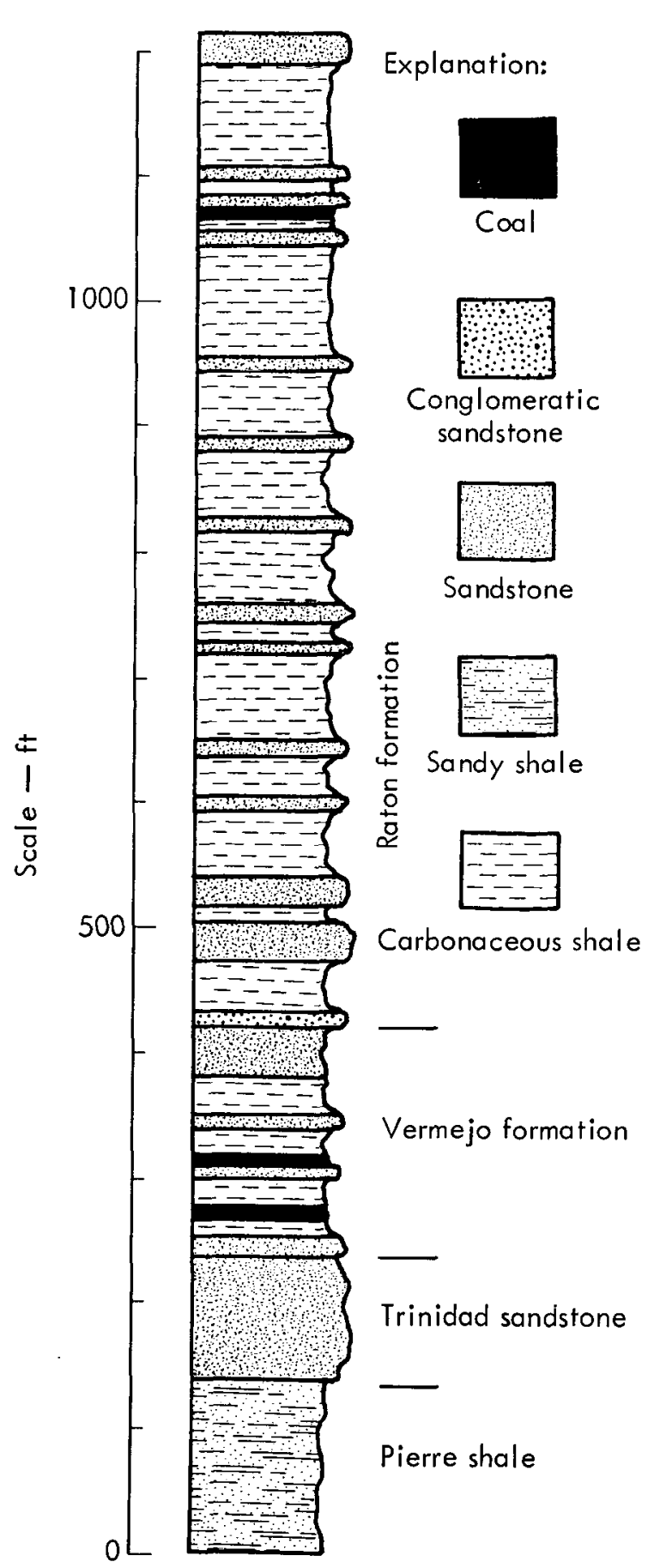

Fig. 3. Generalized stratigraphic section of the Trinidad, Vermejo, and Raton formations.

stratigraphic column of the rocks exposed in the Trinidad area.

The principal structural feature of the Trinidad area is the Raton basin, which is a broad, asymmetrical trough trending 
northward. Isolated normal faults are scattered throughout the area. In the test area the beds dip 5 to $8 \mathrm{deg}$ to the northwest.

The cratering experiments of Project Trinidad were carried out in the Vermejo formation of Late Cretaceous age. The Vermejo formation consists of complexly interbedded grey to black, carbonaceous, coaly, and silty shale; buff, grey, and grey-green arkosic sandstone; grey and dark-grey siltstone; and coal. The bedding is thin-to-massive. The thinner beds are parallel stratified and parallel laminated, but the thicker beds are lenticular and irregular. The sandstone is composed of very-fine-to-medium-sized grains of quartz, feldspar, mica, and ferromagnesian minerals cemented by clay and calcium carbonate. The sandstone is highly friable and contains carbonized plant remains. The shale is mostly nonfissile and has a wide range of sand and carbonaceous content. The coal beds, which are interbedded with the shale and siltstone, are of bituminous grade and have been extensively mined. Stratigraphic columns taken from the core holes in the test area are shown in Appendix A.

Overburden in the test area consists of very clayey soil. Platy fragments of sandstone and rounded river-run cobbles are common in the soil. Overburden thicknesses vary from 0 to $15 \mathrm{ft}$ in the test area.

PRESHOT ENGINEERING PROPERTIES OF SITE MEDIUM

This section presents a summary of the engineering properties of the rock at

\footnotetext{
Figures A3 through A6.
}

the Project Trinidad site. The results of the laboratory physical tests are presented in Appendix A.

The unconfined compressive strength of the intact rock ranges from about $450 \mathrm{psi}$ for shale and coal to $8,000 \mathrm{psi}$ for sandstone. The wide range in compres sive strengths reflects the different rock types and the presence of fractures in some of the samples.

Water content of the rocks at Trinidad ranges from 1.2 to $9.2 \%$. The degree of saturation ranges from 58.2 to 89.6 , with an average of about $78 \%$. Porosity values range from 5.3 to $17.0 \%$, and averages about $10 \%$.

The material at the Trinidad test site has an average in situ density of $156 \mathrm{lb} /$ $\mathrm{ft}^{3}\left(2.5 \mathrm{~g} / \mathrm{cm}^{3}\right)$.

Seismic velocities at the Trinidad site varied greatly. Overburden and weathered rock velocities ranged from 1,000 to 2,500 feet per second (fps), a representative velocity for overburden and weathered rock was 1,250 fps. Interbedded sandstone and shale and thinly bedded sandstone had velocities ranging from 2,500 to $6,000 \mathrm{fps}$ (a representative velocity is $5,000 \mathrm{fps})$. The massive, unweathered sandstone had a velocity that ranged from 7,000 to $8,500 \mathrm{fps}$ (a representative velocity is $7,500 \mathrm{fps}$ ).

The rock quality designation, RQD, ${ }^{6}$ was used to determine a qualitative index of the in situ rock mass. The quality of the rock as determined by this method was fair-to-poor (RQD's ranged from 39 to $56 \%$ ). The RQD was developed by Deere and is used as a measure of the in situ quality of the rock. Specifically, 
the RQD is the percentage of core recovery computed by considering only pieces of core longer than $4 \mathrm{in}$. as recovered. Smaller pieces are considered to be due to close shearing, jointing, faulting, or weathering in the rock mass and are not counted. Core loss, weathered and soft zones, are accounted for in the determination. RQD values ranging from 0 to $50 \%$ are indicative of a poor quality rock mass having a small fraction of the strength and stiffness measured for an intact specimen.

The laboratory tests provided another classification based on unconfined compressive strength and modulus of elasticity. ${ }^{7}$ The test results are plotted in Fig. 4 and indicate the rock to be of weakto-intermediate strength.

Fig. 4. Engineering classification for intact rock (after Deere and Miller ${ }^{7}$ ).

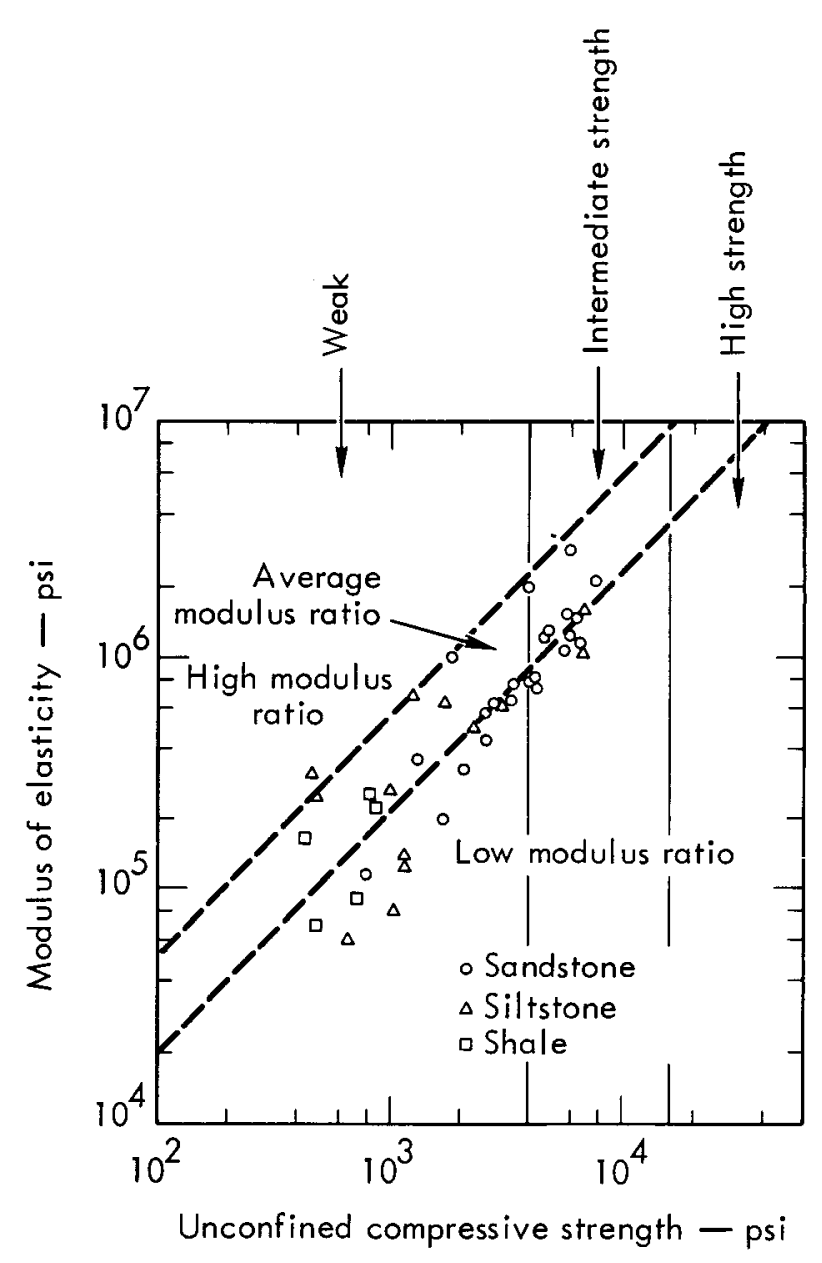

\section{Chapter 3. Crater Measurements}

This chapter presents the cratering information acquired during the $\mathrm{B}, \mathrm{C}$ and $\mathrm{D}$ series of detonations, each series being described in sequence. Some comparative information on explosives, based on the crater measurements, is also included in the discussion. All crater measurements were obtained from plots of conventional survey data, and the volumes of single craters are based on their cross sections and the CRATER DATA computer code. $^{8}$ Volumes of row craters are based on cross sectional areas measured with a planimeter and the application of Simpson's rule.
Preshot and postshot ground surveys were made along two orthongonal lines for the single craters, and at selected locations along the alinements of the row craters.

A postshot aerial view of the primary test area, showing most of the craters in Project Trinidad, is shown in Fig. 5. Experiments D1, D2, and D3 were located in another area about a mile away. The craters in the blocked-off areas in Fig. 5 were part of separate studies $^{1,5}$ and are not discussed in this report. A preshot topographic map of the same area is shown in Appendix $A$. 


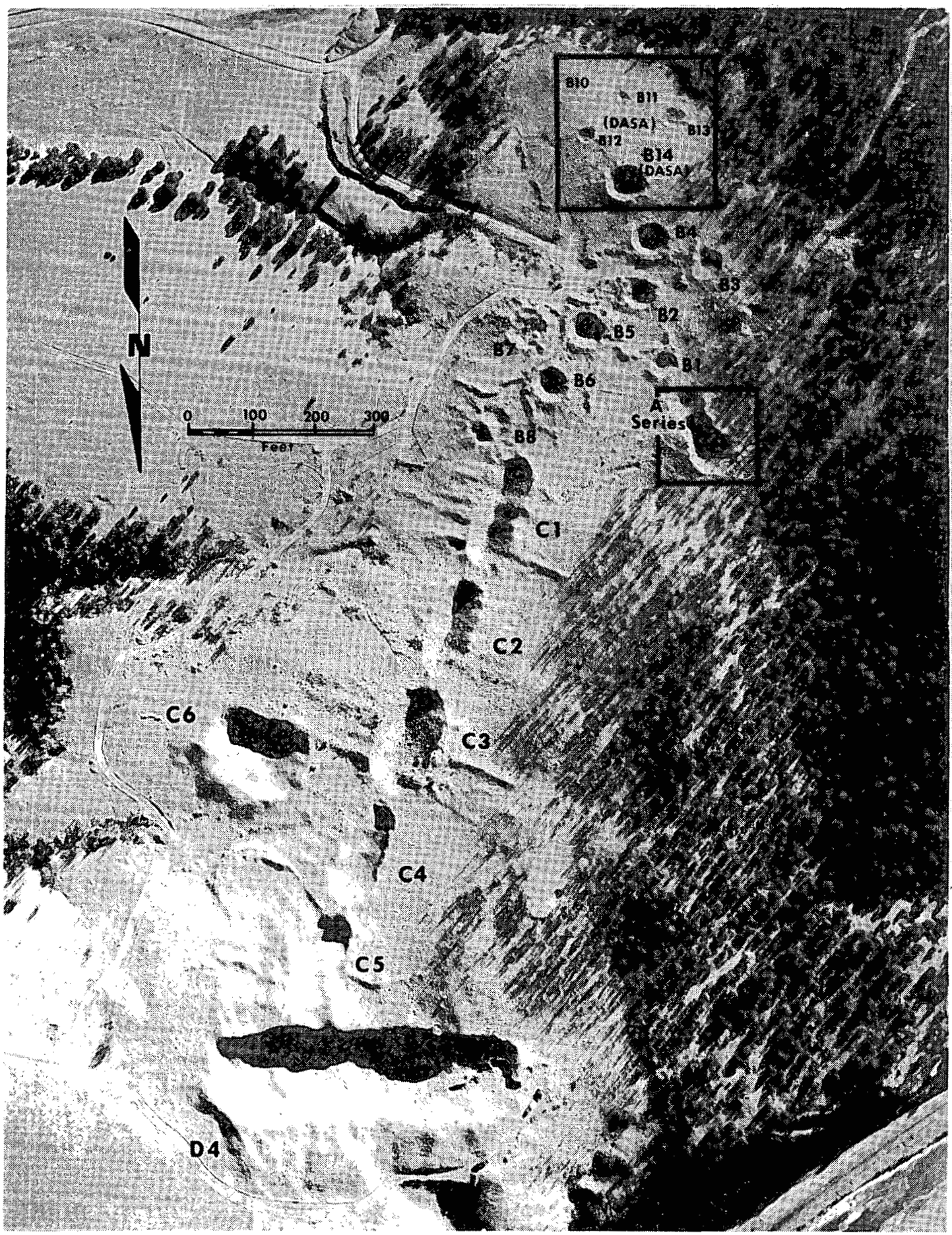

Fig. 5. Aerial view of principal experimental area showing B series, C series, and the D4 crater.

\section{B-SERIES}

The B-series consisted of eight 1-ton charges detonated at various depths of burst. The principal objectives of this series were to obtain optimum crater dimensions and depths of burst to be used as a design base for the follow-on rowcharge experiments, and to compare the cratering effectiveness of ANFO and a 
metallized slurry. The design approach was to assume that the optimum depth of burial would be near $1.9 \mathrm{ft} / \mathrm{E}^{1 / 3}$ (where $\mathrm{E}$ is the total energy of the explosive in Mcal), and then to bracket this depth. The value of $1.9 \mathrm{ft} / \mathrm{Mcal}^{1 / 3}$ was based on previous cratering experience. In this manner cratering curves could be developed to determine the optimum depth of burial. ANFO was used as the explosive in Detonations B1 through B3, and an aluminized ammonium-nitrate slurry was used in Detonations B4 through B8. Table 2 summarizes the charge emplacement conditions.

The explosives were emplaced in $3-\mathrm{ft}$ diameter holes drilled with the bucket auger shown in Fig. 6. A considerable amount of auxiliary drilling and blasting was required to break the rock in most of the emplacement holes so that it could be removed with the bucket auger. An air- operated, track-mounted drill was used for this supplementary drilling.

After the explosives were emplaced, the holes were stemmed with a mixture of drill cuttings, 3/4-in. aggregate, and water. Except for the two delayed rowcharges, primacord initiated by an electric cap at the surface was used to detonate the charges. A column of boosters extending the full height of the cratering charge was used in all cases. The characteristics of the explosives used in the various phases of the project are shown in Table 3.

The results of the crater measurements program for the 1 -ton $B$-series are given in Table 4. One of the B-series craters is shown in Fig. 7. The apparent radii and the depths of the craters are plotted against depth of burial in Fig. 8, and the apparent crater volumes are plotted against depth of burial in Fig. 9.

Table 2. B-series cratering charges.

\begin{tabular}{|c|c|c|c|c|c|c|c|c|}
\hline \multirow[b]{2}{*}{ Detonation } & \multirow[b]{2}{*}{ Explosive } & \multirow{2}{*}{$\begin{array}{l}\text { Hole } \\
\text { Depth } \\
\text { (ft) }\end{array}$} & \multirow{2}{*}{$\begin{array}{l}\text { Depth to } \\
\text { top of charge } \\
\text { (ft) }\end{array}$} & \multirow{2}{*}{$\begin{array}{l}\text { Charge } \\
\text { height } \\
\text { (ft) }\end{array}$} & \multicolumn{2}{|c|}{ Depth of burst } & \multicolumn{2}{|c|}{ Detonation } \\
\hline & & & & & & $(\mathrm{ft})$ & Date & Time \\
\hline B1 & $\mathrm{ANFO}^{\mathrm{a}}$ & 18.1 & 12.4 & 5.7 & 15.2 & 16.0 & 13 Aug 71 & 0900 \\
\hline $\mathrm{B} 2$ & ANFO & 20.7 & 15.4 & 5.3 & 18.0 & 18.0 & 14 Aug 71 & 1100 \\
\hline B3 & $\mathrm{ANFO}$ & 22.3 & 17.1 & 5.2 & 19.7 & 20.0 & 12 Aug 71 & 0810 \\
\hline B4 & $\begin{array}{l}\mathrm{AANS}^{\mathrm{b}} \\
(\mathrm{TD}-2)\end{array}$ & 17.9 & 13.9 & 4.0 & 15.9 & 16 & 13 Aug 71 & 1400 \\
\hline B5 & $\begin{array}{l}\text { AANS } \\
(T D-2)\end{array}$ & 20.4 & 16.8 & 3.6 & 18.6 & 19 & 11 Aug 71 & 1400 \\
\hline B6 & $\begin{array}{l}\text { AANS } \\
\text { (TD-2) }\end{array}$ & 22.8 & 19.0 & 3.8 & 20.9 & 21.5 & 10 Aug 71 & 1115 \\
\hline B7 & $\begin{array}{l}\text { AANS } \\
(T D-2)\end{array}$ & 24.3 & 20.9 & 3.4 & 22.6 & 24.0 & 12 Aug 71 & 1440 \\
\hline B8 & $\begin{array}{l}\text { AANS } \\
\text { (TD-2) }\end{array}$ & 30.0 & 26.3 & 3.7 & 28.1 & 28.0 & 11 Aug 71 & 0835 \\
\hline
\end{tabular}

a"ANFO" is the commonly used abbreviation for the explosive consisting of ammonium nitrate $(94.5 \%)$ and fuel oil $(5.5 \%)$.

${ }^{b}$ AANS designates an aluminized ammonium nitrate slurry. This slurry explosive consists primarily of ammonium-nitrate and contains powdered aluminum for greater energy; the explosive was designated TD-2 by the manufacturer, IRECO Chemicals. 


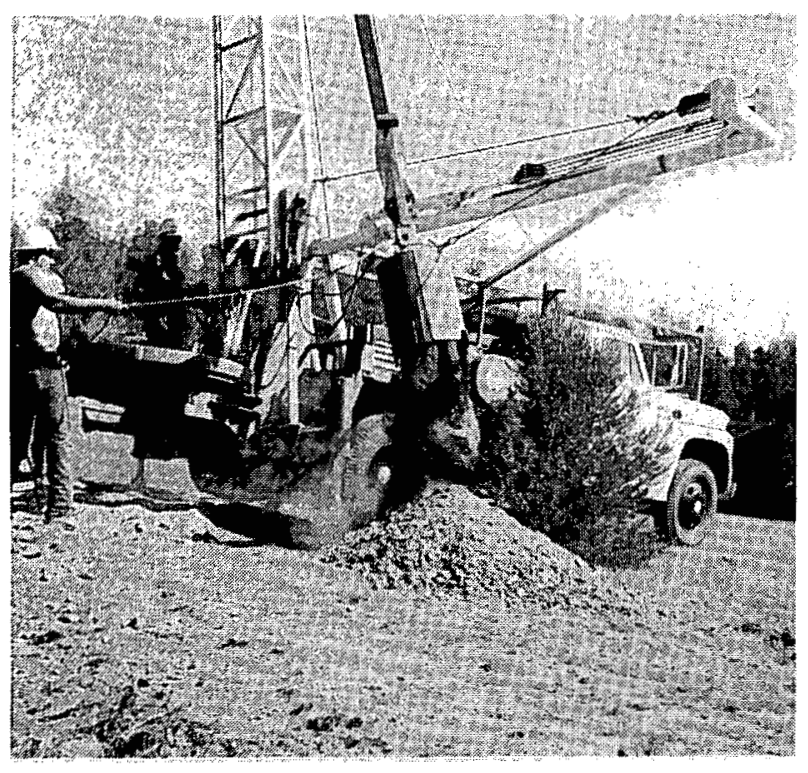

Fig. 6. Bucket auger used to emplace charges.

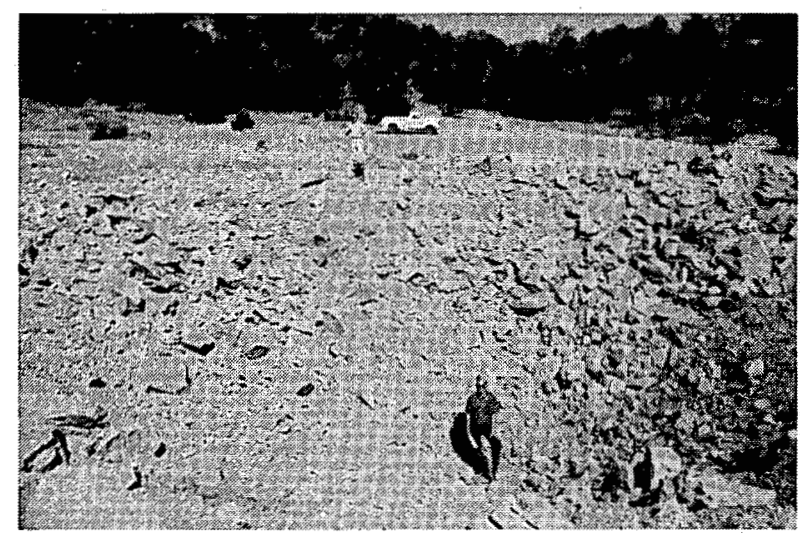

Fig. 7. Typical 1-ton single-charge crater.

Cross sections of the apparent craters are contained in Appendix B.

Considering the wide lateral variations in near surface geology that exist at the test area, the data points in Figs. 8 and 9 show remarkably little scatter about the (visual) best-fit curves drawn through the points. The anamalous appearing crossover of the crater radius curves for slurry and ANFO can probably be attributed to almost $10 \mathrm{ft}$ of overburden present

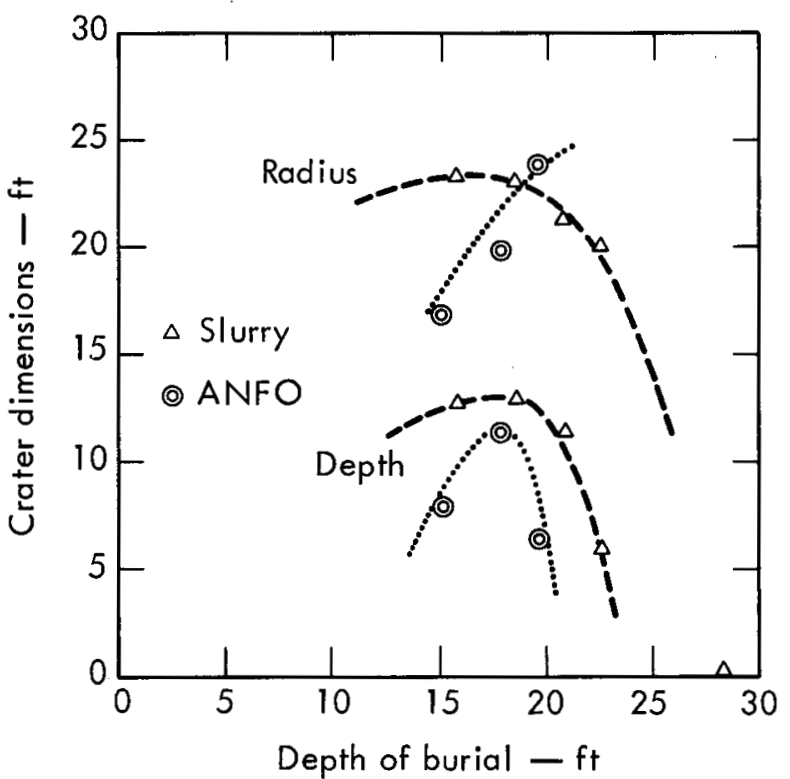

Fig. 8. Apparent crater radii and depths for $B$ series.

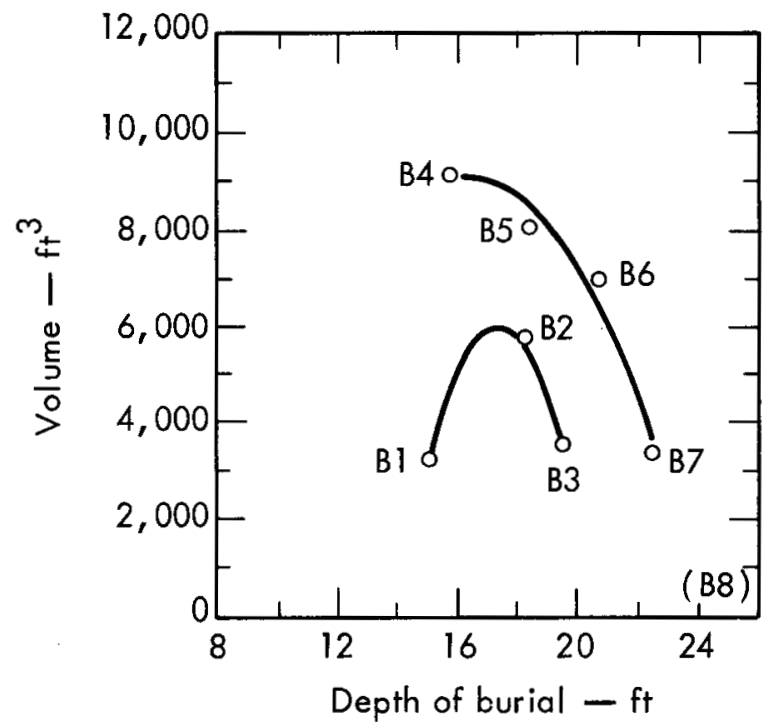

Fig. 9. Volumes of B series apparent craters.

at the location of Detonation B3. Overburden depths at the other ground zeros did not exceed $4 \mathrm{ft}$, except for B4 which has $9 \mathrm{ft}$.

On the basis of Figs. 8 and 9, the following optimum crater dimensions for 
Table 3. Characteristics of Project Trinidad explosives.

\begin{tabular}{cccccc}
\hline Detonation & Explosive & $\begin{array}{c}\text { Density } \\
\left(\mathrm{g} / \mathrm{cm}^{3}\right)\end{array}$ & $\begin{array}{c}\text { Detonation } \\
\text { velocity } \\
(\mathrm{m} / \mathrm{sec})\end{array}$ & $\begin{array}{c}\text { Bubble } \\
\text { energy } \\
(\mathrm{cal} / \mathrm{g})\end{array}$ & $\begin{array}{c}\text { Aluminum } \\
\text { content } \\
(\%)\end{array}$ \\
\hline $\begin{array}{c}\text { B1-B3 } \\
\text { D1 }\end{array}$ & ANFO $^{\mathrm{c}}$ & 0.9 & 4000 & 450 & - \\
$\begin{array}{c}\text { B4-B8 } \\
\text { C1-C6 } \\
\text { D4 }\end{array}$ & AANS $^{\mathrm{d}}(\mathrm{TD}-2)^{\mathrm{e}}$ & 1.35 & 4450 & 860 & 18 \\
$\begin{array}{c}\text { D2 } \\
\text { D3 }\end{array}$ & AANS (TD-1) & 1.25 & 4500 & 540 & 5 \\
\hline
\end{tabular}

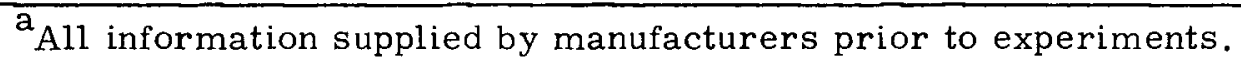

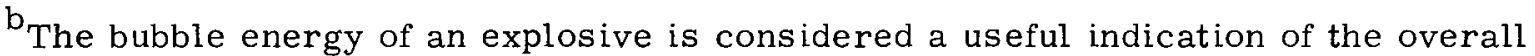
explosive energy; it is more readily measured than shock energy.

${ }^{c}$ Ammonium nitrate and fuel oil.

d Aluminized ammonium nitrate slurry.

e Manufacturer's designation; formulated for Project Trinidad by IRECO Chemicals (slurry).

f Manufacturer's designation; manufactured by Gulf Chemicals (slurry).

$\mathrm{g}_{\text {After }}$ the completion of the experiments, the bubble energy of IR-10 was reported by the manufacturer to be approximately $400 \mathrm{cal} / \mathrm{g}$, and the detonation velocity $4040 \mathrm{~m} / \mathrm{sec}$.

1 -ton charges were selected for use in future designs:

Radius (ft)

Depth (ft)

Depth of burial (ft)

Volume $\left(\mathrm{ft}^{3}\right)$

A comparison of the relative cratering efficiencies of the two explosives, ANFO and the TD-2 slurry, can be made on the basis of the optimum crater dimensions and volumes. Let us assume that 1 ton of the TD-2 explosive is a more effective cratering explosive than an equal weight of ANFO by a factor " $k$ "; i.e., 1 ton of TD-2 will produce the same crater as $\mathrm{k}$ tons of ANFO. We also assume that dimensions scale as the charge weight to the 0.3 power. The actual dimensions of the largest B-series crater formed by 1 ton of each explosive are:

Radius (ft) $\frac{\text { TD-2 }}{23.3} \quad \frac{\text { ANFO }}{20.0}$

Depth (ft)

13.0

11.5

So that comparing radii:

$$
\frac{\text { radius } \mathrm{TD}-2}{\text { radius } \mathrm{ANFO}}=\mathrm{k}^{0.3}=\frac{23.2}{20.0}=1.16 \text {; }
$$

therefore,

$$
\mathrm{k}=1.64 \text {. }
$$

And comparing crater depths:

$$
\frac{\text { depth TD-2 }}{\text { depth ANFO }}=\mathrm{k}^{0.3}=\frac{13.0}{11.5}=1.13 \text {; }
$$

therefore,

$$
\mathrm{k}=1.5 \text {. }
$$


Table 4. B-series crater dimensions. ${ }^{a}$

\begin{tabular}{|c|c|c|c|c|c|c|}
\hline Detonation & $\begin{array}{c}\text { Depth } \\
\text { of burst, } \\
\text { DOB } \\
\text { (ft) }\end{array}$ & $\begin{array}{c}\text { Apparent } \\
\text { crater } \\
\text { radius, } \\
\mathrm{R}_{\mathrm{a}} \\
(\mathrm{ft})\end{array}$ & $\begin{array}{c}\text { Apparent } \\
\text { crater } \\
\text { depth, } \\
\mathrm{D}_{\mathrm{a}} \\
(\mathrm{ft})\end{array}$ & $\begin{array}{c}\text { Lip crest } \\
\text { radius, } \\
\mathrm{R}_{\mathrm{al}} \\
(\mathrm{ft})\end{array}$ & $\begin{array}{c}\text { Lip } \\
\text { height, } \\
\mathrm{H}_{\mathrm{al}} \\
\text { (ft) }\end{array}$ & $\begin{array}{c}\text { Lip } \\
\text { radius, } \\
\mathrm{R}_{\mathrm{eb}} \\
(\mathrm{ft})\end{array}$ \\
\hline B1 & 15.2 & 17 & 8.0 & 22 & 2.5 & 60 \\
\hline $\mathrm{B} 2$ & 18.0 & 20 & 11.5 & 25 & 3.8 & 60 \\
\hline B3 & 19.7 & 24 & 6.5 & 27 & 1 & 35 \\
\hline B4 & 15.9 & 23.5 & 12.8 & 28 & 3.1 & 60 \\
\hline B5 & 18.6 & 23.2 & 13.0 & 30 & 3.4 & 70 \\
\hline B6 & 20.9 & 21.5 & 11.5 & 29 & 3.7 & 70 \\
\hline B7 & 22.6 & 20.2 & 6.0 & 32 & 2.6 & 60 \\
\hline B8 & 28.1 & $-{ }^{b}$ & $\ldots$ & - b & $-b$ & - b \\
\hline
\end{tabular}

${ }^{a}$ Cross-sections of the apparent craters are presented in Appendix B; a diagram showing standard crater nomenclature appears as Fig. B1.

${ }^{b}$ Mound; charge buried too deep to crater.

And comparing crater volumes:

$$
\frac{\text { volume } T D-2}{\text { volume ANFO }}=k=\frac{9000}{6000}=1.5 \text {. }
$$

The values of $\mathrm{k}$ resulting from the comparisons above indicate that the aluminized TD-2 slurry is about $50 \%$ more effective as a cratering explosive than ANFO. The TD-2 explosive was used for the entire $\mathrm{C}$-series (which immediately followed the single-charge experiments described above) and for the $\mathrm{D} 4$ railway cut. ANFO was used, however, in the next two railway cuts, $R R-2$ and $R R-3 .^{4}$

\section{C-SERIES}

There were six row-charge detonations in this series: three rows in which the charges were detonated simultaneously, two in which millisecond delays were introduced between charges, and one simultaneously detonated double row.

The three simultaneously detonated rows were designed to test a hypothesis of row crater "enhancement." The term enhancement designates the increase in width and depth of a row crater that occurs when the spacing between charges in a row is progressively reduced. The degree of enhancement is simply the ratio of the depth or width of a row crater to the depth or diameter of the single crater that would be created by one of the charges in the row buried at optimum depth. Previous cratering experiments ${ }^{9}$ in a very weak clay-shale resulted in an empirical formulation of a relationship between enhancement and charge spacing. ${ }^{10}$ The first three rows, $\mathrm{C} 1$ through C3, were to determine whether the same relationship was also valid for relatively stronger rock such as sandstone.

The purpose of the two row-charges with the delays between charges, Experiments $\mathrm{C} 4$ and $\mathrm{C} 5$, was to observe the reduction of airblast, ground shock, and crater size that would result from the delays. It was believed that the lessening 
of crater dimensions might be more than offset by a favorable reduction of the potentially damaging effects of blast and shock, consequently widening the potential for the application of explosive excavation.

In the course of conducting the $\mathrm{C}$ series, the decision was made to excavate explosively a railway cut for the relocation of the Colorado and Wyoming Railroad. The selected excavation was sufficiently wide that a double row of charges would be required. The last experiment in the $\mathrm{C}$-series, $\mathrm{C} 6$, was an attempt to acquire design information about double row-charges.

The explosives were emplaced in the same manner as in the B-series; i.e., in 3 -ft diameter holes drilled with a bucket auger. Each charge was nominally 1-ton of the IRECO TD-2 ammonium-nitrate slurry. Holes were stemmed with pitrun gravel, a small amount of drill cuttings, and water. The simultaneous rows were detonated with primacord, and the two delayed rows used a specially fabricated delay-cap assembly, which was embedded in sand a foot or two above the charges. Charge emplacement data are summarized in Table 5.

Simultaneous Rows (C1, C2, C3)

Rows $\mathrm{C} 1, \mathrm{C} 2$, and $\mathrm{C} 3$ were designed according to the following relationship between enhancement and charge spacing:

$$
\mathrm{e}^{2}=\frac{1.4}{\mathrm{~S} / \mathrm{R}_{\mathrm{a}}}
$$

where

$$
\begin{aligned}
e= & \text { enhancement of row crater } \\
& \text { dimensions relative to dimen- } \\
& \text { sions of optimum single crater }
\end{aligned}
$$

$$
\begin{aligned}
S & =\text { charge spacing } \\
R_{a} & =\text { optimum single crater radius }
\end{aligned}
$$

Row-charges at a given spacing should be buried more deeply than the optimum single-charge depth of burial by the amount of enhancement. The above relationship implies that there will be no enhancement at a charge spacing of $1.4 \mathrm{R} a$.

As previously mentioned, this formula was developed and tested in a series of row cratering experiments ${ }^{9}$ in clay shale. Implicit in the derivation of this relationship is the assumption that a charge in a row is about $30 \%$ more efficient in cratering than is a single charge; i.e., one charge in a row of charges will eject $30 \%$ more rock than it would if detonated by itself. The concept of row crater enhancement means that the size of the crater can be varied by adjusting the spacing and depth of the charges. For example, a row-charge to excavate a channel with a varying depth of cut can be designed by varying the spacing between charges of equal size as the depth of the cut varies.

The design philosophy for the first three rows (C1, C2, C3) was to emplace each row at a constant but different charge spacing, and then to compare the ratio of observed row crater dimensions to those of a single crater. If the results were in accord with the enhancement equation above, then the principles of row-charge design would be firmly established.

The charge spacings selected for the three rows were $1.4 \mathrm{R}_{\mathrm{a}}, 1.1 \mathrm{R}_{\mathrm{a}}$, and $0.8 \mathrm{R}_{a}$, where $R_{a}$ is the radius of the optimum single crater. These spacings were arbitrarily selected to provide a 
Table 5. C-series charge emplacement.

\begin{tabular}{|c|c|c|c|c|c|c|c|c|}
\hline \multirow{2}{*}{$\begin{array}{l}\text { Charge } \\
\text { number }\end{array}$} & \multirow{2}{*}{$\begin{array}{l}\text { Charge } \\
\text { spacing } \\
\text { (ft) }\end{array}$} & \multirow{2}{*}{$\begin{array}{l}\text { Hole } \\
\text { depth } \\
\text { (ft) }\end{array}$} & \multirow{2}{*}{$\begin{array}{c}\text { Depth to } \\
\text { top of charge } \\
\text { (ft) }\end{array}$} & \multirow{2}{*}{$\begin{array}{l}\text { Charge } \\
\text { height } \\
\text { (ft) }\end{array}$} & \multicolumn{2}{|c|}{ Depth of burst } & \multicolumn{2}{|c|}{ Detonation } \\
\hline & & & & & & & Date & Time \\
\hline $\mathrm{C} 1 \mathrm{~A}$ & & 19.9 & 16.5 & 3.4 & 18.2 & C & & \\
\hline C1B & $1.4 \mathrm{R}$ & 20.1 & 16.2 & 3.9 & 18.2 & & & \\
\hline $\mathrm{C} 1 \mathrm{C}$ & & 20.2 & 16.2 & 4.0 & 18.2 & $\{18.0\}$ & $\{28$ Sep 71 & $1000\}$ \\
\hline $\mathrm{C} 1 \mathrm{D}$ & 32.0 & 20.0 & 16.3 & 3.7 & 18.2 & & & \\
\hline $\mathrm{C} 1 \mathrm{E}$ & & 19.2 & 15.4 & 3.8 & 17.3 & C & $\zeta$ & \\
\hline $\mathrm{C} 2 \mathrm{~A}$ & & 22.1 & 18.1 & 4.0 & 20.1 & & & \\
\hline $\mathrm{C} 2 \mathrm{~B}$ & $1.1 \mathrm{R}_{\mathrm{a}}$ & 22.0 & 18.3 & 3.7 & 20.2 & & & \\
\hline $\mathrm{C} 2 \mathrm{C}$ & & 22.2 & 18.6 & 3.6 & 20.4 & $\{20.4\}$ & $\{29$ Sep 71 & $1000\}$ \\
\hline $\mathrm{C} 2 \mathrm{D}$ & 25.0 & 21.9 & 18.4 & 3.5 & 20.2 & & & \\
\hline $\mathrm{C} 2 \mathrm{E}$ & & 20.7 & 17.2 & 3.5 & 19.0 & C & 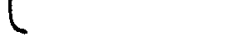 & \\
\hline C3A & & 24.7 & 21.6 & 3.1 & 23.2 & & & \\
\hline $\mathrm{C} 3 \mathrm{~B}$ & & 24.8 & 20.9 & 3.9 & 22.9 & & & \\
\hline $\mathrm{C} 3 \mathrm{C}$ & $0.8 \mathrm{R}_{\mathrm{g}}$ & 25.7 & 21.3 & 4.4 & 23.5 & & & \\
\hline C3D & & 25.0 & 20.6 & 4.4 & 22.8 & $\{23.5\}$ & $\{1$ Oct 71 & $0910\}$ \\
\hline C3E & 18.0 & 24.9 & 20.5 & 4.4 & 22.7 & & & \\
\hline C3F & & 24.7 & 20.7 & 4.0 & 22.7 & & & \\
\hline C3G & ( & 25.4 & 21.7 & 3.7 & 23.6 & ( & ( & \\
\hline $\mathrm{C} 4 \mathrm{~A}$ & & 22.4 & 19.4 & 3.0 & 20.9 & 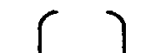 & & \\
\hline C4B & $1.1 \mathrm{R}_{\mathrm{g}}$ & 22.4 & 18.8 & 3.6 & 20.6 & & & \\
\hline C $4 \mathrm{C}$ & & 22.3 & 19.2 & 3.1 & 20.8 & $\{20.4\}$ & 1 Oct 71 & $1500\}$ \\
\hline C4D & 25.0 & 21.9 & 18.8 & 3.1 & 20.4 & & $50-\mathrm{msec}$ de- & \\
\hline $\mathrm{C} 4 \mathrm{E}$ & & 22.3 & 18.9 & 3.4 & 20.6 & L & lay between & \\
\hline C5A & & 21.7 & 18.1 & 3.6 & 19.9 & r & & \\
\hline $\mathrm{C} 5 \mathrm{~B}$ & $1.1 \mathrm{R}$ & 22.0 & 18.8 & 3.2 & 20.4 & & & \\
\hline $\mathrm{C} 5 \mathrm{C}$ & & 21.6 & 18.4 & 3.2 & 20.0 & $\{20.4\}$ & 2 Oct 71 & 1000 \\
\hline C5D & 25.0 & 21.9 & 18.4 & 3.5 & 20.2 & & $25-\mathrm{msec}$ de- & \\
\hline $\mathrm{C} 5 \mathrm{E}$ & & 22.5 & 18.5 & 4.0 & 20.5 & & $\begin{array}{l}\text { lay between } \\
\text { charges }\end{array}$ & \\
\hline C6A & & 22.5 & 17.8 & 4.7 & 20.2 & C & & \\
\hline $\mathrm{C} 6 \mathrm{~B}$ & $1.1 \mathrm{R}$ & 21.7 & 18.1 & 3.6 & 19.9 & & & \\
\hline $\mathrm{C} 6 \mathrm{C}$ & & 21.7 & 17.7 & 4.0 & 19.7 & 20.4 & & \\
\hline C6D & 25.0 & 22.0 & 17.9 & 4.1 & 20.0 & & & \\
\hline $\mathrm{C} 6 \mathrm{E}$ & & 22.6 & 17.6 & 5.0 & 20.1 & & & 1000 \\
\hline C6A' & & 22.4 & 17.8 & 4.6 & 20.1 & & & \\
\hline $\mathrm{C}^{\prime} \mathrm{B}^{\prime}$ & $1.1 \mathrm{R}$ & 22.5 & 17.8 & 4.7 & 20.2 & & & \\
\hline $\mathrm{C} 6 \mathrm{C}^{\prime}$ & & 21.8 & 17.3 & 4.5 & 19.6 & 20.4 & & \\
\hline C6 $D^{\prime}$ & 25.0 & 21.7 & 17.3 & 4.4 & 19.5 & & & \\
\hline C6E' & & 22.6 & 18.2 & 4.4 & 20.4 & & 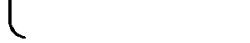 & \\
\hline
\end{tabular}

sufficiently wide range to produce significant changes in crater size.

The results of the C-series are contained in Table 6. Cross sections and profiles for all the $\mathrm{C}$-series craters appear in Appendix B. Figure 10 is a photograph of Crater $\mathrm{C} 3$ that illustrates the size of a typical row crater.
The results of the $\mathrm{C} 1, \mathrm{C} 2$, and $\mathrm{C} 3$ detonations are summarized in Fig. 11, which shows the crater dimensions, expressed in terms of single-crater dimensions, superimposed on the enhancement equation. The agreement between the results and the enhancement predicted by the equation is reasonable. Deviations from 
Table 6. Summary of row crater dimensions. ${ }^{a}$

\begin{tabular}{|c|c|c|c|c|c|c|c|c|c|c|c|c|c|c|c|}
\hline \multirow[b]{2}{*}{ Row } & \multirow{2}{*}{$\begin{array}{c}\text { Number } \\
\text { of } \\
\text { charges }\end{array}$} & \multicolumn{2}{|c|}{ Charge spacing } & \multirow{2}{*}{$\begin{array}{l}\text { Average } \\
\text { depth of } \\
\text { burst } \\
\text { (ft) }\end{array}$} & \multicolumn{3}{|c|}{ Half-width $\left(\mathrm{w}_{\mathrm{a}} / 2\right)$} & \multicolumn{3}{|c|}{ Depth $\left(\mathrm{D}_{\mathrm{ar}}\right)$} & \multicolumn{3}{|c|}{ Enhancement (avg) ${ }^{b}$} & \multirow{2}{*}{$\frac{\mathrm{w}_{\mathrm{al}}}{\mathrm{w}_{\mathrm{a}}}$} & \multirow{2}{*}{$\frac{\mathrm{H}_{\mathrm{al}}}{\mathrm{D} \text { ar }}$} \\
\hline & & $\begin{array}{l}\mathrm{s} / \mathrm{K} \\
(\mathrm{ft})\end{array}$ & $\underset{(f t)}{S}$ & & $\begin{array}{l}\mathrm{Min} \\
(\mathrm{ft})\end{array}$ & $\begin{array}{r}\mathrm{Avg} \\
(\mathrm{ft})\end{array}$ & $\underset{(\mathrm{ft})}{\operatorname{Max}}$ & $\begin{array}{l}\operatorname{Min} \\
(\mathrm{ft})\end{array}$ & $\begin{array}{c}A v g \\
(\mathrm{ft})\end{array}$ & $\begin{array}{c}\operatorname{Max} \\
(\mathrm{ft})\end{array}$ & Predicted & $w_{a} 72$ & $\frac{\mathrm{g}}{\mathrm{D}_{\mathrm{ar}}}$ & & \\
\hline $\mathrm{C} 1$ & 5 & 1.4 & 32 & 18.0 & 21.7 & 24.0 & 26.0 & 10.5 & 12.8 & 15.0 & 1.0 & 1.04 & 0.98 & 1.42 & 0.42 \\
\hline $\mathrm{C} 2$ & 5 & 1.1 & 25 & 20.0 & 22.5 & 25.5 & 28.5 & 13.0 & 14.1 & 14.8 & 1.13 & 1.11 & 1.08 & 1.43 & 0.39 \\
\hline $\mathrm{C} 3$ & 7 & 0.8 & 18 & 23.0 & 31.7 & 33.7 & 34.7 & 14.3 & 18.9 & 22.0 & 1.32 & 1.47 & 1.45 & 1.42 & 0.41 \\
\hline $\mathrm{C} 4$ & 5 & 1.1 & 25 & 20.6 & 24.0 & 25.4 & 26.2 & 8.5 & 10.8 & 12.1 & \multicolumn{3}{|c|}{ (50-msec delay) } & 1.35 & 0.39 \\
\hline $\mathrm{C} 5$ & 5 & 1.1 & 25 & 20.2 & 20.7 & 26.5 & 32.2 & 8.6 & 12.8 & 14.6 & \multicolumn{3}{|c|}{ (25-msec delay) } & 1.32 & 0.31 \\
\hline $\mathrm{C} 6$ & 10 & 1.1 & 25 & 20.0 & \multicolumn{6}{|c|}{ (See profiles and cross sections) } & \multicolumn{3}{|c|}{ (double row) } & - & - \\
\hline
\end{tabular}

${ }^{a}$ Crater dimensions apply to the linear section of the crater, as defined by the shaded area in $F$ ig. B1 of Appendix $B$.

${ }^{b}$ The dimensions of the optimum single crater, as derived from the B-series, are $R_{\mathrm{a}}=23 \mathrm{ft}, \mathrm{D}_{\mathrm{a}}=13 \mathrm{ft}$, and optimum $\mathrm{DOB}=18 \mathrm{ft}$. The median crater slope angle (measured at the preshot ground surface) is $34 \mathrm{deg}$.

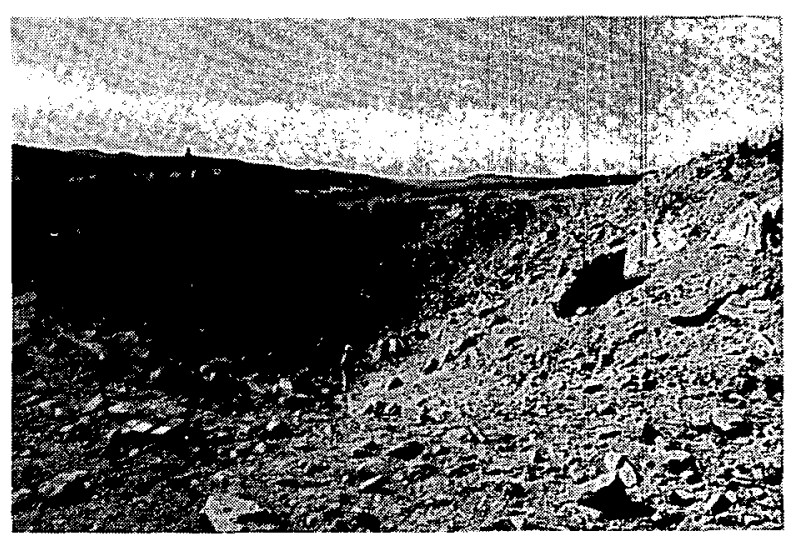

Fig. 10. C3 row crater.

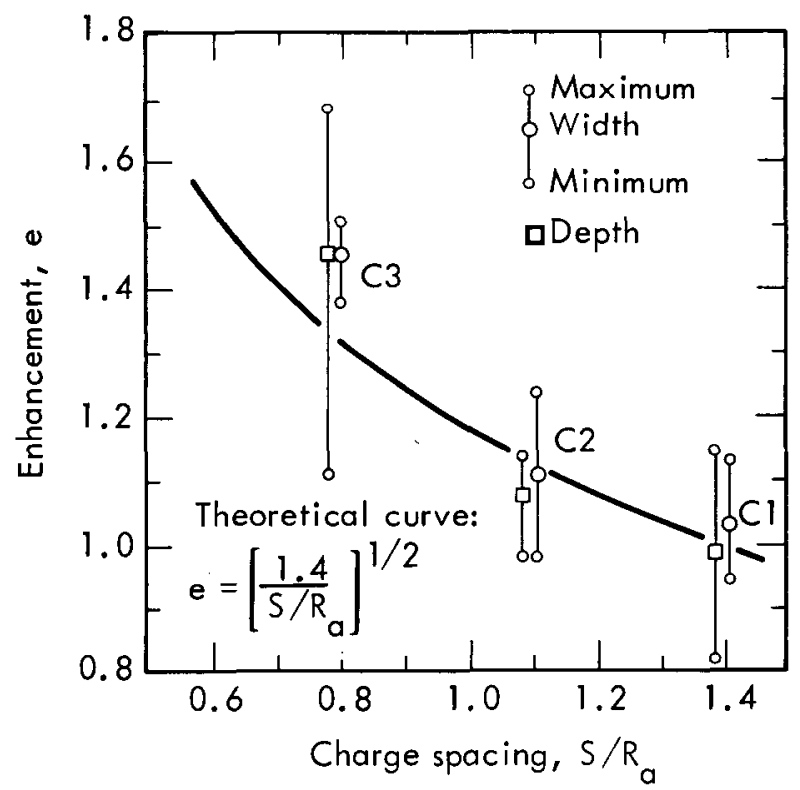

Fig. 11. Row crater enhancement vs charge spacing. the relationship are believed attributable to normal scatter. It appears that the enhancement concept is valid for all practical purposes, although further experiments may lead to modification or refinements.

The results of the three simultaneous rows are presented in a somewhat different format in Fig. 12, in which the row crater dimensions have been superimposed on the single-charge cratering curves for the same explosive. Ideally the row crater dimensions should plot along the lines passing through the origin and the peaks of the curves. Although the information is essentially the same as that shown in Fig. 11, Fig. 12 illustrates the reason that the depth of burst of the charges must be increased as the charge spacing is decreased and the crater becomes larger.

It is interesting to note that the C3 crater, produced by closely spaced 1 -ton charges, is equivalent to what would have been excavated by 3.5 -ton charges spaced at $1.4 \mathrm{R}_{\mathrm{a}}$. This is apparent when the yield increase required for a dimensional increase of 1.46 times is computed:

$$
\frac{\mathrm{W}}{\mathrm{eq}}^{0.3}=1.46
$$




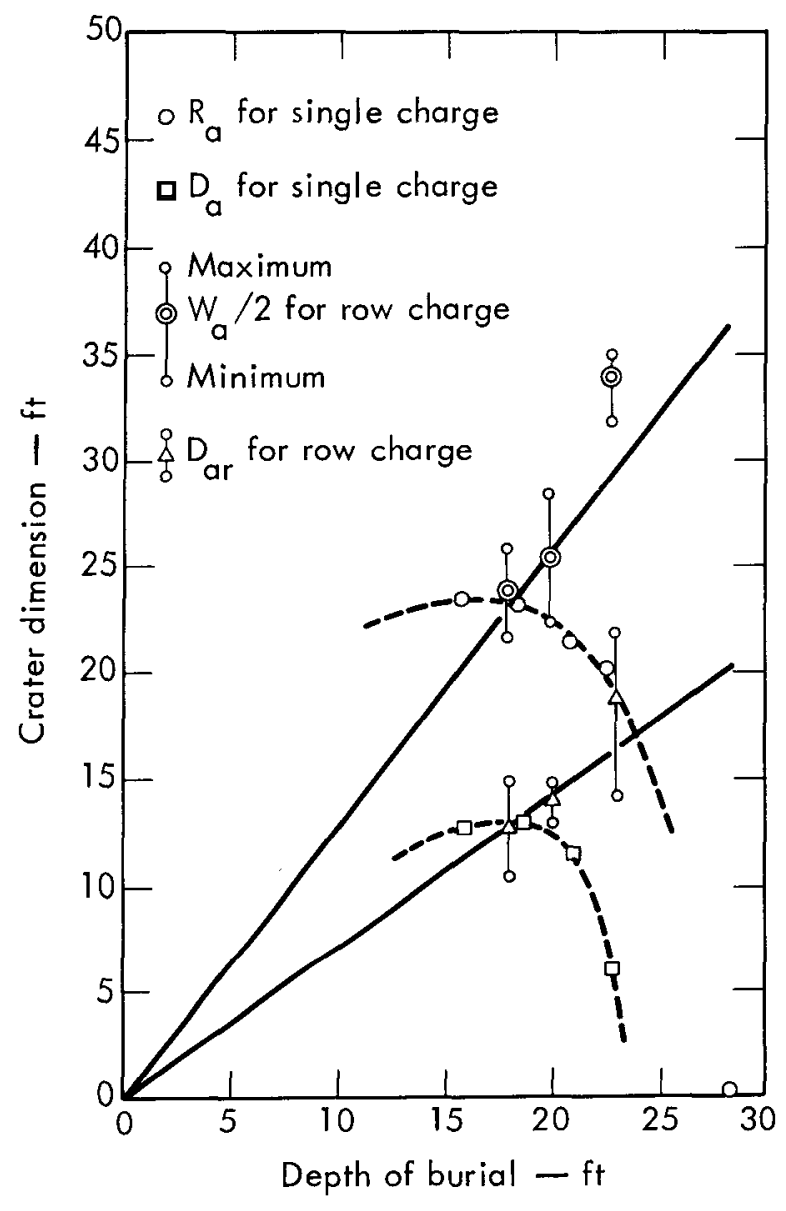

Fig. 12. Single-charge cratering curves with row-crater dimensions superimposed. where $\mathrm{W}_{\text {eq }}$ is the equivalent yield of the 1 -ton charges in the $\mathrm{C} 3$ row. It follows that:

$$
\mathrm{w}_{\text {eq }}=1.46^{3.33} \simeq 3.5 \text { tons. }
$$

It is implicit in the derivation of the enhancement formula that, for a given rock type, each charge in a row will always excavate the same volume of material regardless of the charge spacing. The unit volume, or cubic feet of apparent crater per ton of explosive, was determined for each row in the $\mathrm{C}$-series. This unit volume is also compared to the optimum single volume and is tabulated in Table 7. The data in Table 7 for rows $\mathrm{C} 1, \mathrm{C} 2$, and $\mathrm{C} 3$ show that row $\mathrm{C} 2$ deviated the most from the nominal figure of 1.3 for row-charge efficiency relative to that of a single charge. This, however, is not reflected in the crater dimensions, which agree well with the predicted enhancement.

The average volume of apparent crater for rows $\mathrm{C} 1, \mathrm{C} 2$, and $\mathrm{C} 3$ is $11,140 \mathrm{ft}^{3} /$ ton of explosive, and when this is compared

Table 7. Unit volumes for C-series row craters.

\begin{tabular}{ccc}
\hline Row (charge spacing) & $\begin{array}{c}\text { Volume/ton of explosive } \\
\left(\mathrm{ft}^{3}\right)\end{array}$ & $\begin{array}{c}\text { Volume per ton/ } \\
\text { single crater volume }\end{array}$ \\
\hline $\mathrm{C} 1\left(1.4 \mathrm{R}_{\mathrm{a}}\right)$ & 11,620 & 1.28 \\
$\mathrm{C} 2\left(1.1 \mathrm{R}_{\mathrm{a}}\right)$ & 9,425 & 1.04 \\
$\mathrm{C} 3\left(0.8 \mathrm{R}_{\mathrm{a}}\right)$ & 12,375 & 1.36 \\
$\mathrm{C} 4\left(1.1 \mathrm{R}_{\mathrm{a}}\right)^{\mathrm{b}}$ & 8,500 & 0.93 \\
$\mathrm{C} 5\left(1.1 \mathrm{R}_{\mathrm{a}}\right)^{\mathrm{c}}$ & 9,690 & 1.06 \\
C6 $(\text { double row })^{\mathrm{d}}$ & 8,920 & 0.98 \\
\hline
\end{tabular}

\footnotetext{
${ }^{\mathrm{a}}$ For linear portion of crater; all craters excavated with TD-2 explosive.

$\mathrm{b}_{50}$-msec delay between charges.

$c_{25-m s e c}$ delay between charges.

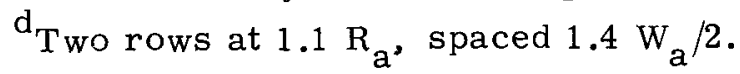


with the $9,100-\mathrm{ft}^{3}$ volume of the optimum single crater formed by $\mathrm{TD}-2$, the average row charge/single charge efficiency is 1.25. There is insufficient data to warrant changing the value of 1.3 , currently in use, to the lower value of 1.25. The average value of $11,140 \mathrm{ft}^{3} /$ ton for the simultaneous row-charges will be used as a reference in the discussion on the delayed rows that follows.

\section{Delayed Row-Charges (C4, C5)}

The evaluation of a particular explosive excavation project may indicate that ground shock or airblast constraints would render the project infeasible if all the charges in a row were detonated simultaneously. Two of the $\mathrm{C}$-series detonations, $\mathrm{C} 4$ and $\mathrm{C} 5$, were planned to determine whether the use of millisecond time delays between charges would reduce ground shock and airblast effects without significantly reducing the volume of material excavated. The charge spacing in these two rows was established at $1.1 \mathrm{R}_{\mathrm{a}}$ so that the results could be compared to row $\mathrm{C} 2$, the corresponding simultaneously detonated row. However, because $\mathrm{C} 2$ had what appears to be an anomalously low unit volume, the delayed rows will be compared with the average unit volume for all three simultaneously detonated rows.

It was necessary to decide before the row-charges were emplaced the time delays to be used. A-50 msec delay was selected for row $\mathrm{C} 4$, with the option of delaying the charges in row $\mathrm{C} 5$ by either 25 or $100 \mathrm{msec}$, the final decision to be based on the appearance of the $\mathrm{C} 4$ crater. The reduction of the ground shock generated by the $\mathrm{C} 4$ detonation was so signifi- cant that there was no reason to try a longer delay period in C5. Consequently, the 25-msec delay period was chosen for the $\mathrm{C} 5$ row.

The dimensions of Craters $\mathrm{C} 4$ and $\mathrm{C} 5$ are given in Table 5. When these dimensions are compared with the dimensions of row $\mathrm{C} 2$, it appears that a delay between charges has almost no effect on crater width and a significant effect on crater depth. With the depth of $\mathrm{C} 2$ as a reference, a 25-msec delay reduced the depth of $\mathrm{C} 5$ to $91 \%$, and the $50-\mathrm{msec}$ delay reduced the depth of $\mathrm{C} 4$ to $77 \%$ of the depth of C2. The craters are shallowest at the end at which the delay sequence started. A more meaningful analysis can be made by comparing the unit volumes of the delayed rows to the average unit volume of all three simultaneous rows. When the average unit volume of $11,140 \mathrm{ft}^{3} /$ ton for rows $\mathrm{C} 1, \mathrm{C} 2$, and $\mathrm{C} 3$ is taken, the 25-msec delay reduced the volume of apparent crater per ton of explosives to $87 \%$ of the average, and the $50-\mathrm{msec}$ delay to $75 \%$ of the average. The corresponding reductions of ground shock and airblast are discussed in later chapters.

Double Row-Charge Detonation (C6)

The $\mathrm{C} 6$ detonation was originally planned as a single, delayed row. When it became apparent that a double row of charges would be required to achieve the width of a planned railroad cut, a preliminary double-row experiment was believed necessary. One of the rows in the $\mathrm{C} 6$ detonation had already been drilled at a spacing of $1.1 \mathrm{R}_{\mathrm{a}}$ when the decision was made to convert it to a double row, and so the second row was drilled for the same charge spacing. 
The separation between the two rows was set at 1.5 times the half-width $\left(1.5 \mathrm{~W}_{\mathrm{a}} / 2\right)$ of a single row. The factor of 1.5 was based on observations made in smaller scale experiments, and was believed to be close to the maximum separation that could be used without creating a ridge along the crater bottom. The half-width of a row with a spacing of $1.1 \mathrm{R}_{\mathrm{a}}$ is predicted with the enhancement formula:

$$
\begin{aligned}
e^{2} & =\frac{1.4}{1.1}=1.27 \\
e & =1.13
\end{aligned}
$$

$$
\text { and } \begin{aligned}
\mathrm{W}_{\mathrm{a}} / 2 & =\mathrm{eR}_{\mathrm{a}} \\
& =1.13 \times 23 \\
& \simeq 25 \mathrm{ft} .
\end{aligned}
$$

Therefore, the rows were separated by

$$
1.5 \mathrm{w}_{\mathrm{a}} / 2 \simeq 39 \mathrm{ft} .
$$

A cross section near the middle of $\mathrm{C} 6$ is shown in Fig. 13, which shows the preshot terrain, the charge emplacement, and the actual crater outline. Additional sections are contained in Appendix B. Ideally, C6 would be expected to have an average depth of $\mathrm{eD}_{\mathrm{a}}(1.13 \times 13=14.7 \mathrm{ft})$ over the $39 \mathrm{ft}$ wide portion between the rows. From Fig. 13 it is evident that this depth was not achieved and that the crater was shallower. The shallowest portions of the crater are on the downslope side of the preshot terrain. The average depth of $\mathrm{C} 6$ for the area between the rows is $11.5 \mathrm{ft}$. The shallowest cross section has an average depth of $11.0 \mathrm{ft}$ and the deepest cross section an average depth of $14.7 \mathrm{ft}$. As shown in Table 6 the average amount of material excavated by each charge was $98 \%$ of the optimum single 1 -ton crater volume.

A subsequent review of available information on double row detonations indicated that the use of a short time delay between the detonation of the two rows would produce a larger crater. Several small scale experiments confirmed this, and a time delay was incorporated into later double row experiments at Trinidad.

D-SERIES

Tests of the D-series were intended to provide an opportunity to experiment with row-charges in nonlevel terrain. Almost all of the previous EERL experience with row charges had been with detonations in predominantly level and flat terrain.

There were several objectives for the D-series experiments. The first experiment, D1, was designed according to the concept of enhancement to cut a channel with a constant bottom elevation through a ridge-like topography. Two sidehill cuts were attempted, one with a single row of charges (D2) and one with a double row of charges (D3). The final D-series detonation was a delayed double row to excavate a railroad cut. The pertinent information is summarized in Table 8.

Single-Row Charge through Varying Terrain (D1)

This shot was a single row of ANFO charges designed to cut a channel with a constant bottom elevation through a ridge. For design purposes, the deepest portion of the cut was assumed to be $15 \mathrm{ft}$ and the 

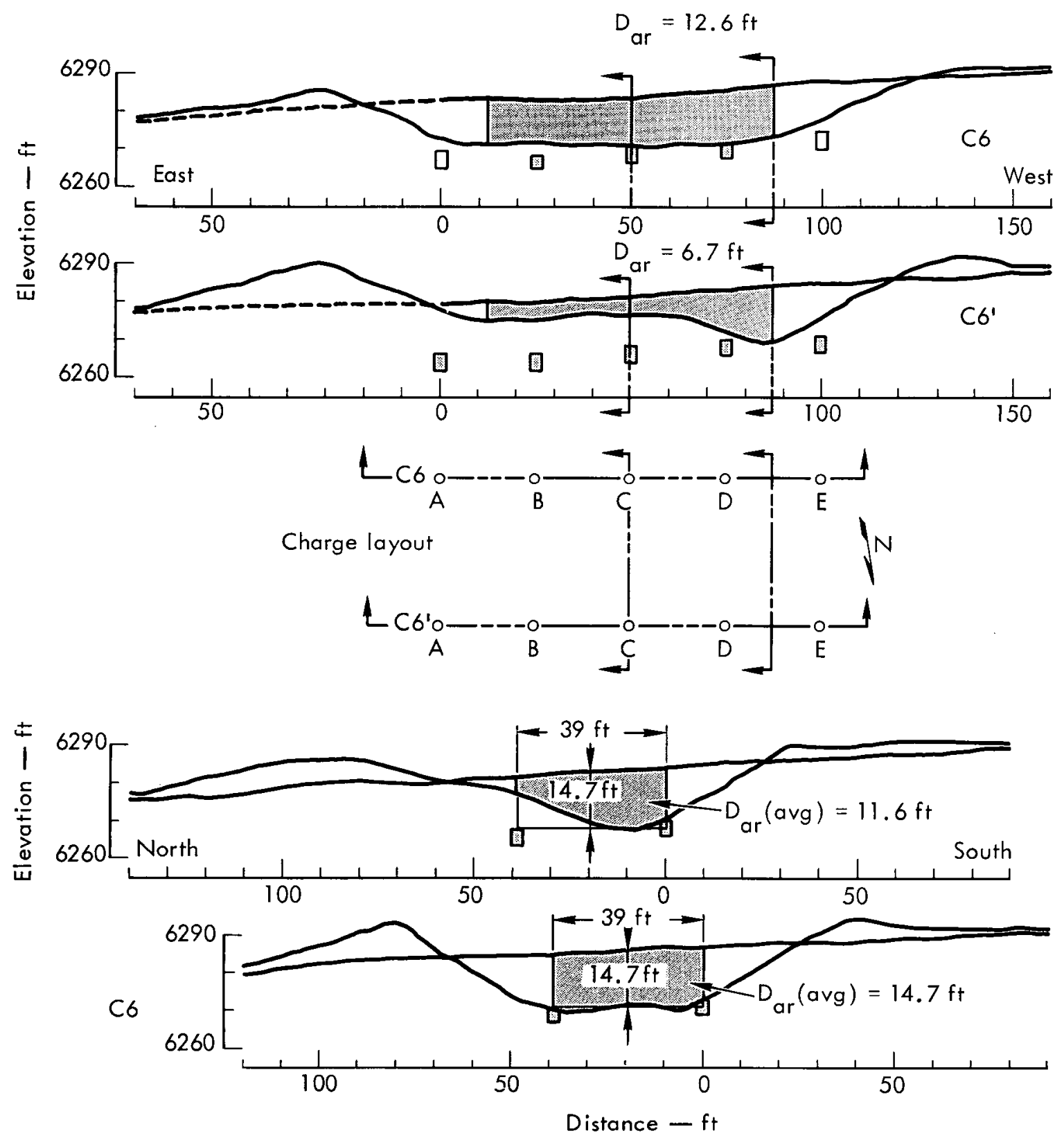

Fig. 13. Longitudinal profiles, charge layout, and cross sections of C6 crater.

length was $110 \mathrm{ft}$. The shot was designed using varying charge weights and constant enhancement; i.e., a constant charge spacing in terms of $S / R_{a}$.

Figure 14 is a profile view of the charge layout showing the design depth and the actual crater bottom along both the centerline and the deepest portion of the crater.
The single crater dimensions for ANFO were used to design this experiment. The optimum dimensions, observed in the B-series, were:

$$
\begin{aligned}
& \mathrm{R}_{\mathrm{a}}=20 \mathrm{ft} / \operatorname{ton}^{0.3} \\
& \mathrm{D}_{\mathrm{a}}=11 \mathrm{ft} / \operatorname{ton}^{0.3} \\
& \mathrm{DOB}=17 \mathrm{ft} / \mathrm{ton}^{0.3}
\end{aligned}
$$


Table 8. Summary of D-series experiments.

\begin{tabular}{ccccc}
\hline Row-charge & $\begin{array}{c}\text { Number of } \\
\text { charges } \\
(\mathrm{lb})\end{array}$ & Explosive & $\begin{array}{c}\text { Weight of } \\
\text { explosive } \\
(1 \mathrm{~b})\end{array}$ & \multicolumn{1}{c}{ Description } \\
\hline $\mathrm{D} 1$, & $\begin{array}{c}9(200 \\
\text { to } 2000)\end{array}$ & ANFO & 9,800 & $\begin{array}{l}\text { Single row to excavate cut } \\
\text { through ridge. }\end{array}$ \\
D2 & $\begin{array}{l}5,1-\text { ton } \\
\text { D3 }\end{array}$ & TD-1 & 10,000 & $\begin{array}{l}\text { Single row along side hill. } \\
\text { Double row of charges along } \\
\text { side hill. } \\
\text { Double row, delayed; rail- } \\
\text { way cut } 400 \text { ft long. }\end{array}$ \\
\hline
\end{tabular}

${ }^{a}$ Designations defined in Table 3 .

The design was started at the deepest point of the cut, arbitrarily selected to be $15 \mathrm{ft}$. It was also decided that charge weights would not exceed $2,000 \mathrm{lb}$. Because an unenhanced 1-ton ANFO charge will excavate a depth of $11 \mathrm{ft}$, the required amount of enhancement to cut $15 \mathrm{ft}$ with a 1 -ton charge is computed:

$$
\mathrm{e}=\frac{15}{11}=1.36 \text {; }
$$

so that the charge spacing to achieve this enhancement can be computed as:

$$
\mathrm{S} / \mathrm{R}_{\mathrm{a}}=\frac{1.4}{\mathrm{e}^{2}}=\frac{1.4}{1.85}=0.76
$$

This spacing was rounded to $\mathrm{S} / \mathrm{R}_{\mathrm{a}}=0.8$.

The method of computing the weights and spacings of the remaining charges in the row are documented in Ref. 11. As an example of this design procedure, refer to Fig. 14 and consider the charge immediately to the right of the 2,000-1b charge at $0+68$. The weight and position of this charge was determined by measuring the depth of cut a distance $0.8 \mathrm{R}_{\mathrm{a}}$ to the right of the first charge (i.e., 0.8 $\times \mathrm{R}_{\mathrm{a}}$ for a 2,000-1b ANFO charge $=0.8$ $\times 20=16 \mathrm{ft}$ ). This depth of cut is approx-

imately $12.5 \mathrm{ft}$. Because we are using enhancement of 1.36, this depth can be reduced by this factor in order to compute the charge weight required at this location. We therefore have an effective depth of cut of:

$$
\frac{12.5}{1.36}=9.2 \mathrm{ft}
$$

and the charge weight required, $W$, can then be found:

$$
\begin{aligned}
\frac{2000^{0.3}}{11} & =\frac{\mathrm{W}^{0.3}}{9.2} \\
\mathrm{w}^{0.3} & =2000^{0.3} \times \frac{9.2}{11} \\
\mathrm{~W} & =1120 \mathrm{lb} .
\end{aligned}
$$

This weight was rounded to $1,200 \mathrm{lb}$ to be slightly conservative. The charge is then placed at a distance from the 2,000-1b charge equal to the average of 0.8 times the crater radii of the two adjacent charges. The crater radius for a $1,200-1 b$ charge is:

$$
20\left(\frac{1200}{2000}\right)^{0.3} \simeq 17 \mathrm{ft} .
$$

The spacing is then $0.8\left(\frac{20+17}{2}\right) \simeq 15 \mathrm{ft}$. 


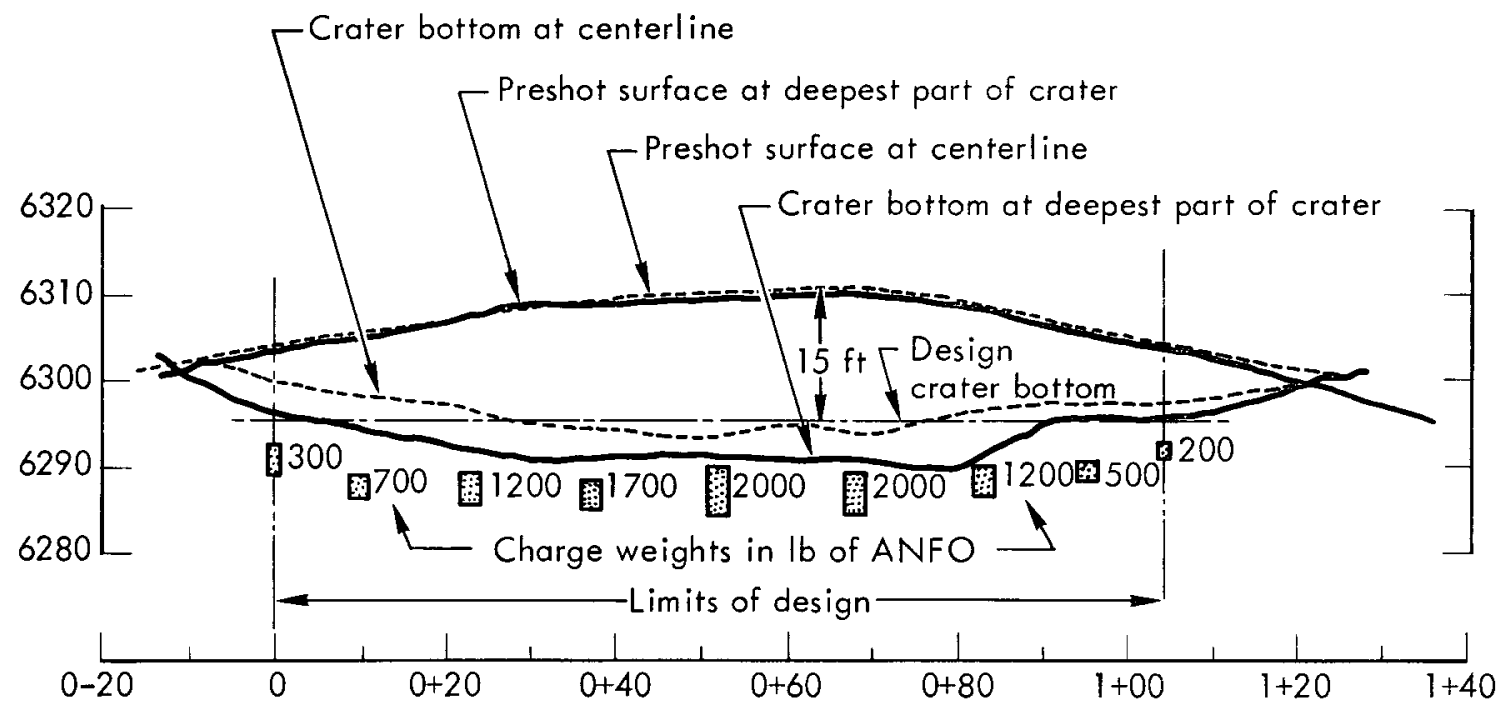

(a)
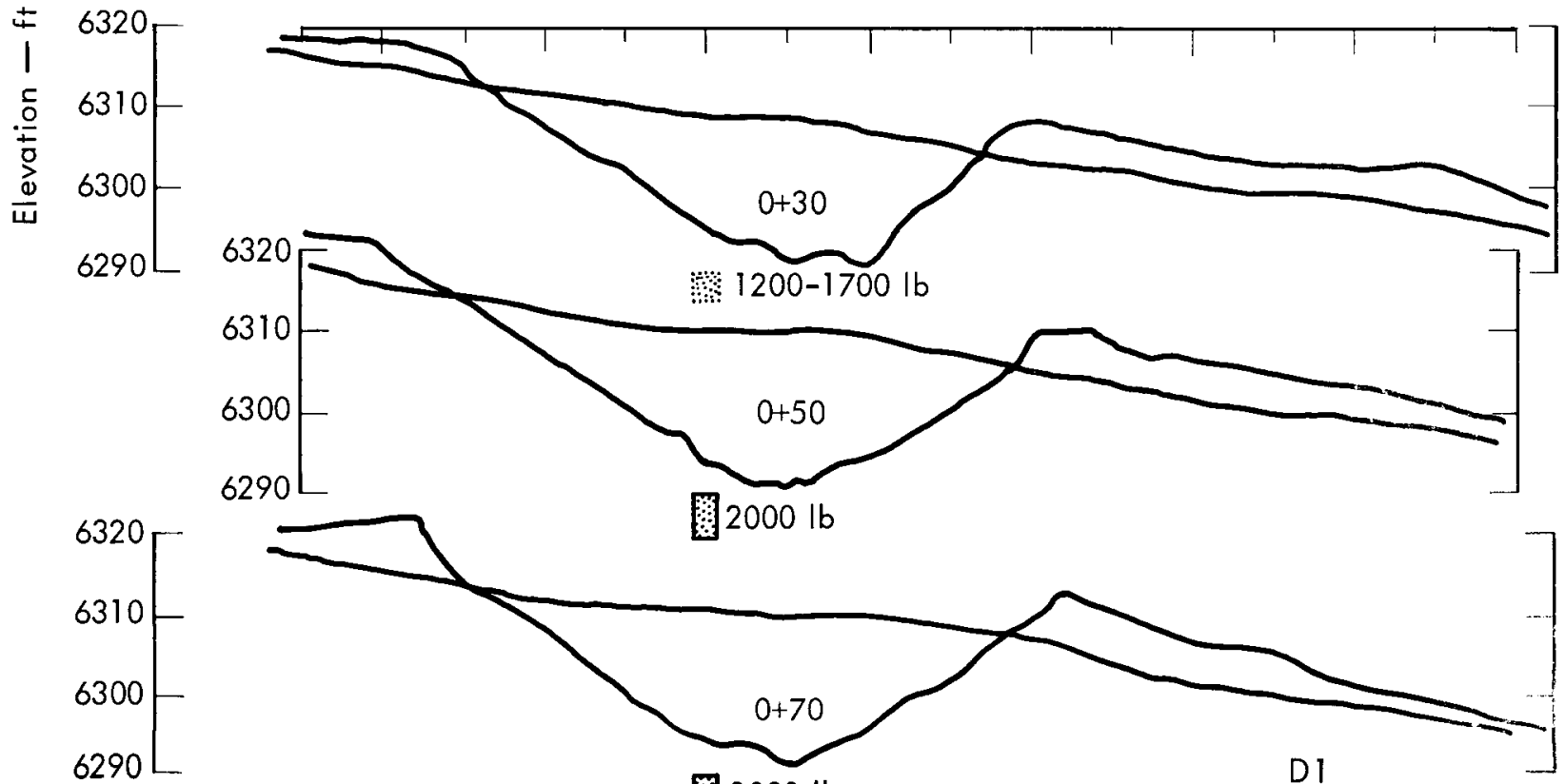

$2000 \mathrm{lb}$

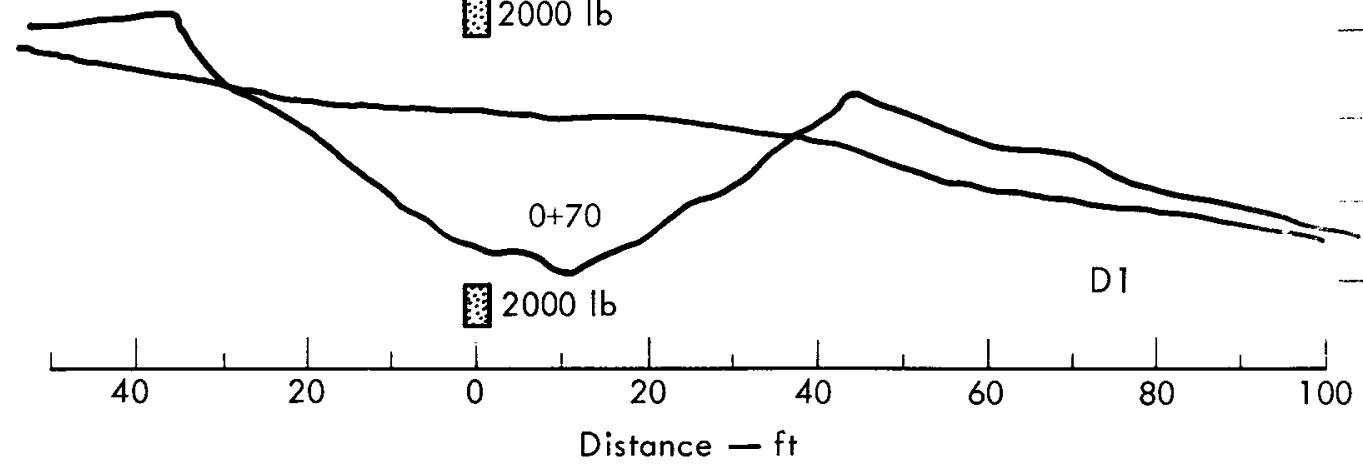

(b)

Fig. 14. D1 crater preshot terrain, charge layout, cross sections, and crater profile.

The same procedure is followed for the remaining charges. As indicated above, this procedure is more fully explained in Ref. 11. Table 9 contains the charge emplacement data for Experiment D1.
The D1 crater had a maximum depth of $19 \mathrm{ft}$, and the average depth along the deepest part of the crater was $15.2 \mathrm{ft}$. The cross sections in Fig. 14 show that the deepest part of the crater was offset about $10 \mathrm{ft}$ downhill from the centerline. 
Table 9. D1, D2, D3 charge emplacement.

\begin{tabular}{|c|c|c|c|c|c|c|c|c|c|c|c|}
\hline \multirow{3}{*}{$\begin{array}{l}\text { Charge } \\
\text { number }\end{array}$} & \multirow{3}{*}{$\begin{array}{l}\text { Hole } \\
\text { depth } \\
\text { (ft) }\end{array}$} & \multirow{3}{*}{$\begin{array}{l}\text { Depth to } \\
\text { top of } \\
\text { charge } \\
\text { (ft) }\end{array}$} & \multirow{3}{*}{$\begin{array}{c}\text { Charge } \\
\text { weight } \\
\text { (lb) }\end{array}$} & \multirow{3}{*}{$\begin{array}{l}\text { Charge } \\
\text { height } \\
\text { (ft) }\end{array}$} & \multicolumn{2}{|c|}{ Depth of burst } & \multirow{2}{*}{\multicolumn{2}{|c|}{ Detonation }} & \multirow{3}{*}{$\begin{array}{c}\text { Tempera- } \\
\text { ture } \\
\text { (deg) }\end{array}$} & \multirow{3}{*}{$\begin{array}{l}\text { Wind } \\
\text { (mph) }\end{array}$} & \multirow{3}{*}{ Weather } \\
\hline & & & & & Actual & Design & & & & & \\
\hline & & & & & & & Time $(\mathbb{N}$ & (ST) Date & & & \\
\hline D1 A & 15.2 & 11.6 & 300 & 3.6 & 13.4 & 13.0 & \multirow{9}{*}{1115} & \multirow{9}{*}{ Nov 70} & \multirow{9}{*}{51} & \multirow{9}{*}{$5 \mathrm{NE}$} & \multirow{9}{*}{ Clear } \\
\hline $\mathrm{D} 1 \mathrm{~B}$ & 18.4 & 15.9 & 700 & 2.5 & 17.1 & 17.5 & & & & & \\
\hline $\mathrm{D} 1 \mathrm{C}$ & 22.1 & 18.4 & 1200 & 3.7 & 20.2 & 20.5 & & & & & \\
\hline D1 D & 24.5 & 21.1 & 1700 & 3.4 & 22.8 & 23.0 & & & & & \\
\hline $\mathrm{D} 1 \mathrm{E}$ & 26.0 & 20.1 & 2000 & 5.9 & 23.0 & 23.5 & & & & & \\
\hline D1F & 26.2 & 21.2 & 2000 & 5.0 & 23.7 & 23.5 & & & & & \\
\hline $\mathrm{D} 1 \mathrm{G}$ & 22.0 & 18.5 & 1200 & 3.5 & 20.2 & 20.5 & & & & & \\
\hline $\mathrm{D} 1 \mathrm{H}$ & 16.5 & 14.9 & 500 & 1.6 & 15.7 & 16.0 & & & & & \\
\hline D1 I & 12.3 & 10.8 & 200 & 1.5 & 11.5 & 11.0 & & & & & \\
\hline $\mathrm{D} 2 \mathrm{~A}$ & 22.3 & 13.3 & 2000 & 9.0 & 17.8 & \multirow{5}{*}{18.0} & \multirow{5}{*}{1030} & \multirow{5}{*}{18 Nov 70} & \multirow{5}{*}{49} & \multirow{5}{*}{0} & \multirow{5}{*}{ Clear } \\
\hline $\mathrm{D} 2 \mathrm{~B}$ & 22.2 & 13.5 & 2000 & 8.7 & 17.8 & & & & & & \\
\hline $\mathrm{D} 2 \mathrm{C}$ & 22.3 & 13.0 & 2000 & 9.3 & 17.6 & & & & & & \\
\hline $\mathrm{D} 2 \mathrm{D}$ & 22.1 & 13.5 & 2000 & 8.6 & 17.8 & & & & & & \\
\hline $\mathrm{D} 2 \mathrm{E}$ & 22.0 & 13.1 & 2000 & 8.9 & $17.5)$ & & & & & & \\
\hline D3A & 22.1 & 15.8 & 2000 & 6.3 & 19.0 & \multirow{7}{*}{19.0} & \multirow{13}{*}{$1015^{a}$} & \multirow{13}{*}{19 Nov 70} & \multirow{13}{*}{45} & \multirow{13}{*}{$0-5 E$} & \multirow{13}{*}{ Clear } \\
\hline D3B & 22.2 & 16.3 & 2000 & 5.9 & 19.2 & & & & & & \\
\hline D3C & 21.5 & 16.2 & 2000 & 5.3 & 18.9 & & & & & & \\
\hline D3 D & 22.5 & 16.6 & 2000 & 5.9 & 19.5 & & & & & & \\
\hline D3 E & 22.2 & 16.9 & 2000 & 5.3 & 19.5 & & & & & & \\
\hline D3 F & 21.7 & 15.7 & 2000 & 6.0 & 18.7 & & & & & & \\
\hline & & & & & & & & & & & \\
\hline$D 3 A^{\prime}$ & 28.9 & 18.3 & 4000 & 10.6 & 23.6 & & & & & & \\
\hline $\mathrm{D}^{\prime} \mathrm{B}^{\prime}$ & 29.3 & 19.1 & 4000 & 10.2 & 24.2 & & & & & & \\
\hline $\mathrm{D} 3 \mathrm{C}^{\prime}$ & 29.5 & 20.5 & 4000 & 9.0 & 25.0 & & & & & & \\
\hline D3 $D^{\prime}$ & 29.7 & 20.3 & 4000 & 9.4 & 25.0 & 25.0 & & & & & \\
\hline D3E' & 29.5 & 18.6 & 4000 & 10.9 & 24.0 & & & & & & \\
\hline D3 $F^{\prime}$ & 30.2 & 18.6 & 4000 & 11.6 & 24.4 & & & & & & \\
\hline
\end{tabular}

${ }^{\mathrm{a}} \mathrm{D} 3$ ' delayed $250 \mathrm{msec}$ after $\mathrm{D} 3$.

The maximum depth beneath the centerline of the charges was about $16 \mathrm{ft}$, and the average half-width at the center of the cut was $34 \mathrm{ft}$. Figure 15 is a photograph of the D1 crater.

A rather surprising result of the D1 detonation is the volume of apparent crater that was excavated. The volume of the crater from $0+10$ to $0+90$ is $47,200 \mathrm{ft}^{3}$. The charge weight distributed over this portion of the crater was about $8,450 \mathrm{lb}$, so that the unit volume is $11,170 \mathrm{ft}^{3} /$ ton

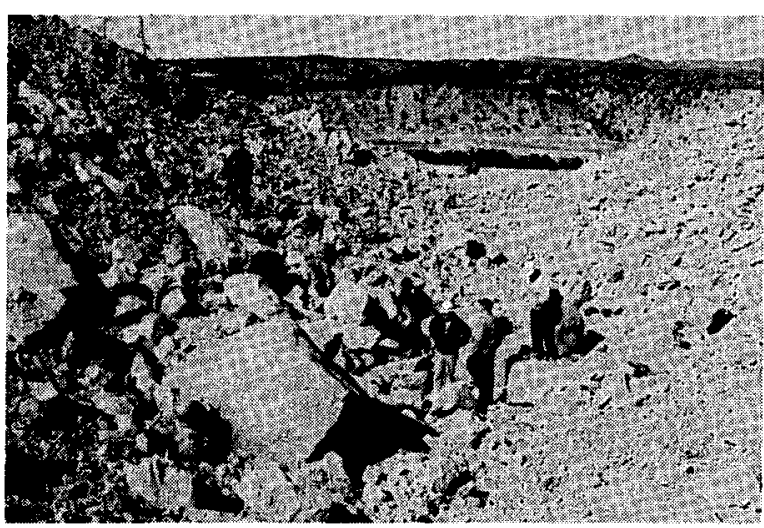

Fig. 15. D1 crater. 
of explosive. This unit volume is nearly a factor of two larger than the observed volume of the optimum single crater excavated by ANFO. The reason for this is not clear. The sidehill topography may have resulted in more material being ejected than would have occurred in level terrain, and the single ANFO crater used as a reference may not have been representative." It appears that despite its smaller total energy content compared to some of the metallized slurries, ANFO is nevertheless an excellent cratering explosive, especially when cost is considered.

Single Row-Charge along a Sidehill (D2)

The charges for the D2 experiment were emplaced in a row along a sidehill. The D2 experiment did not have a specific design objective. Rather, it was a case of emplacing the charges in a row along a sidehill to observe the influence of the slope on crater size and shape.

The experiment was originally designed with the assumption that the TD-2 explosive would be used. However, after the emplacement holes had been drilled at a spacing of $1.4 \mathrm{R}_{\mathrm{a}}$ for $\mathrm{TD}-2$, it was decided to use the less energetic explosive TD-1 because of a surplus. The bubble energy of TD- 1 is $540 \mathrm{cal} / \mathrm{g}$ compared to $860 \mathrm{cal} / \mathrm{g}$ for the TD-2. When it is assumed that crater dimensions vary as the 0.3 power of the bubble energy, ${ }^{\dagger} \mathrm{TD}-1$ should produce a smaller

\footnotetext{
A later experiment in the same area, Railroad Cut RR3 detonated in September 1971 had a unit volume nearly identical to D1. it was also on a sidehill-ridge topogr $:$ phy. 4

T.: : : ctal energies of the explosives whil be rery nearly proportional to their onblin srergies.
}

crater than one produced with TD-2, and it should be smaller by a factor of:

$$
\left(\frac{540}{860}\right)^{0.3}=0.87 \text {. }
$$

If this factor is valid, then the charge spacing for the TD-1 explosive in the D1 experiment was actually $1.4 / 0.87=1.6 \mathrm{R}$ a

Figure 16 shows the centerline profile and charge emplacement, the deepest profile of the crater, and selected cross sections.

The charges were buried at a nominal depth of $18 \mathrm{ft}$, which is a few feet deeper than optimum for this explosive. With the same factor 0.87 that was used to obtain a crater radius for $\mathrm{TD}-1$, the optimum depth of burial for 1-ton of TD-1 would be $18 \times 0.87$, or approximately $15.5 \mathrm{ft}$. Burial depths in this sloping terrain are referred to the nearest free surface rather than the vertical distance between charge and ground surface; in gently sloping terrain there is very little difference.

All charges were detonated simultaneously and the appearance of the crater is shown in Fig. 17. The profiles in Fig. 16 show some cusping between charges caused by the wide spacing. The cusps were about $2 \mathrm{ft}$ higher than the low points in the crater bottom. The average crater depth at its deepest was $7.3 \mathrm{ft}$ (vertical). The unit volume for the D2 crater was $8,000 \mathrm{ft}^{3} /$ ton. Although this figure appears to be low compared to the average value of $11,140 \mathrm{ft}^{3} /$ ton realized in rows $\mathrm{C} 1, \mathrm{C} 2$, and $\mathrm{C} 3$, it is in reasonable agreement with what would be expected on the basis of relative explosive energies. When it is assumed that crater volumes are roughly proportional to bubble energies, D2 could 
Centerline profiles

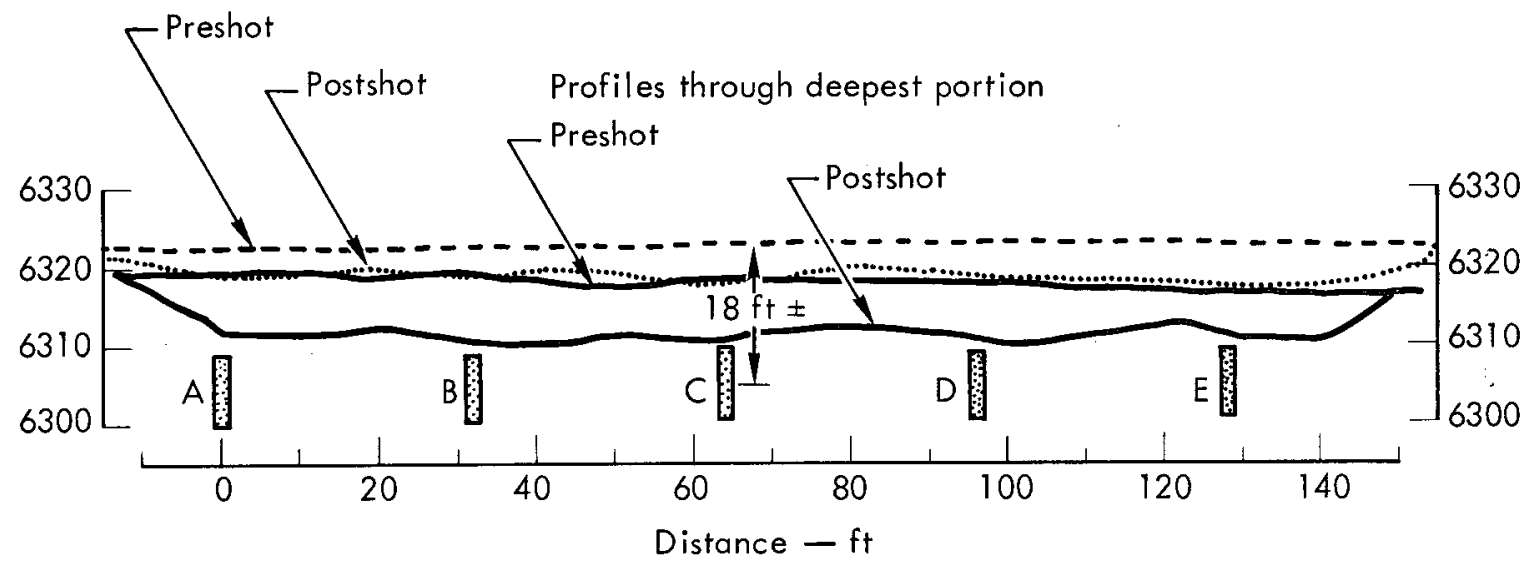

(a)

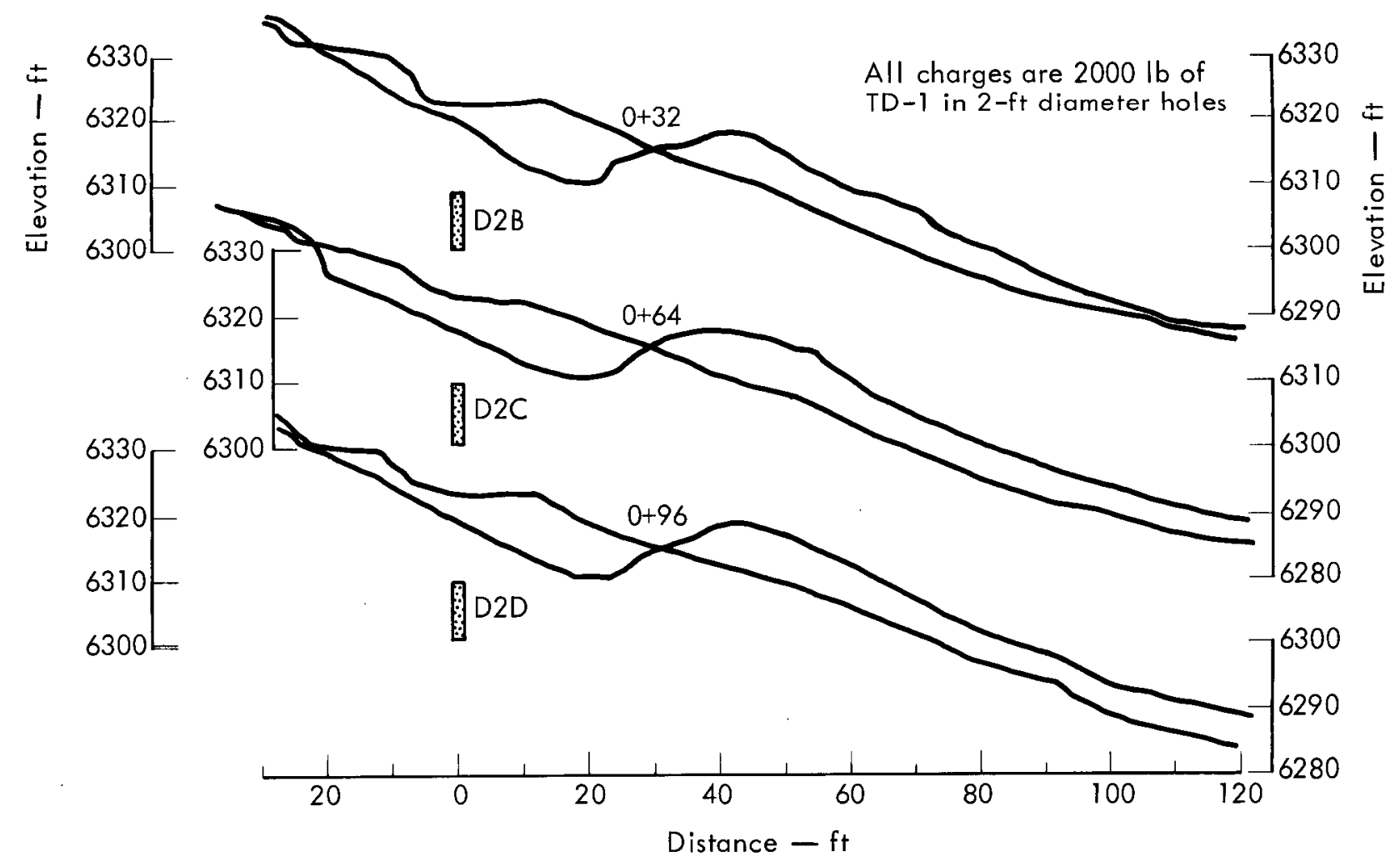

(b)

Fig. 16. Longitudinal profiles and cross section of $\mathrm{D} 2$ crater.

be expected to have a unit volume close to:

$$
\frac{540}{860} \times 11,140=7,000 \mathrm{ft}^{3} / \text { ton } .
$$

That this nominal unit volume was exceeded could be attributed to less fallback into the crater because of the sloping terrain. The deepest portion of the crater 


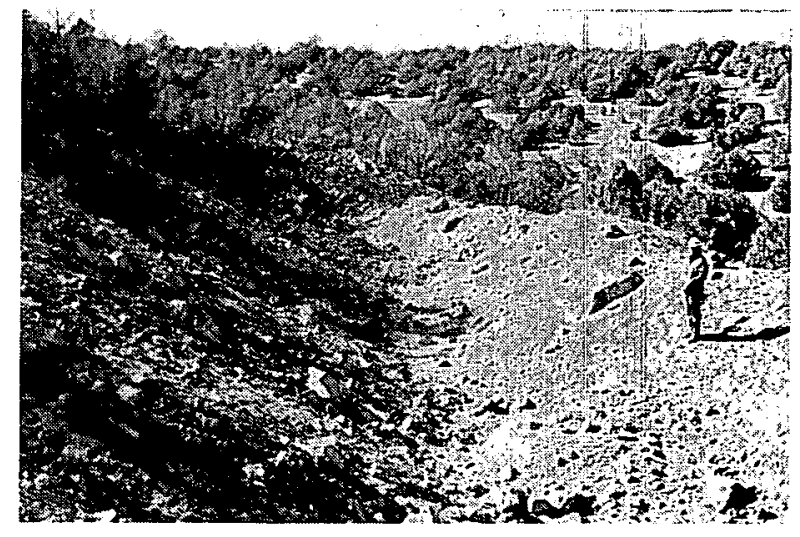

Fig. 17. D2 crater.

is offset about $20 \mathrm{ft}$ downslope from the centerline of the charges, and slumping of the upslope crater wall appears to have occurred.

Although the apparent crater would be only marginal as a potentially useful excavation, there is a large amount of broken rock in the form of fallback that could be excavated and shaped into a useful cut with conventional machinery. The total volume of broken rock probably exceeds the volume of the apparent crater, by at least a factor of three. In some applications of explosive excavation in which machinery woula be used to excàvate the rock, large charges would be buried deeper than cratering depths to break and "mound" the rock; i.e., no ejection from the crater would occur. This technique has been successfully applied in subsequent experiments. 2,12

\section{Double Row-Charge along} a Sidehill (D3)

The primary purpose of the D3 experiment was to test the feasibility of excavating a relatively wide cut along a sidehill by means of two parallel row charges.
Profiles and cross sections of the D3 crater, both preshot and postshot, are shown in Fig. 18. There were six charges in each row, the downslope row consisting of 1 -ton charges and the upslope row containing 2 -ton charges. The explosive, which was surplus from another project, was manufactured by Gulf Chemicals and was designated IR-10. It was an ammonium-nitrate base slurry with a reported aluminum content of approximately $25 \%$. The charges were emplaced in 3-ft diameter holes.

The IR-10 slurry was reported to have a bubble energy of $1,130 \mathrm{cal} / \mathrm{g}$. On the basis of this value of bubble energy relative to that for TD-2, the following optimum single-crater dimensions were estimated for designing D3:

\begin{tabular}{|c|c|c|c|}
\hline & $\mathrm{R}_{\mathrm{a}}(\mathrm{ft})$ & $\mathrm{D}_{\mathrm{a}}(\mathrm{ft})$ & $\mathrm{DOB}(\mathrm{ft})$ \\
\hline TD-2 (1 ton) & 23 & 13 & 18 \\
\hline IR -10 ( 1 ton $)$ & 25 & 14 & 19.5 \\
\hline IR -10 ( 2 tons $)$ & 31 & 16 & 24 \\
\hline
\end{tabular}

The 1-ton charges in the downslope row were spaced at $1.4 \mathrm{R}_{\mathrm{a}}$ apart, which is $35 \mathrm{ft}$. The 2-ton charges in the upslope row were also spaced $35 \mathrm{ft}$ apart, which is equivalent to $1.13 \mathrm{R}_{\mathrm{a}}$ (i.e., 35/31). A single row of charges at this spacing in level terrain should produce an enhancement of single crater dimensions of 1.12; consequently, the optimum depth of burst would be $27 \mathrm{ft}$ (i.e., $1.12 \times 24$ ). The 2 -ton charges were placed so that they were approximately $27 \mathrm{ft}$ from the assumed true crater boundary produced by the downslope row. The charges were buried so that they were also about $27 \mathrm{ft}$ deep. The detonation of the row of 2-ton 


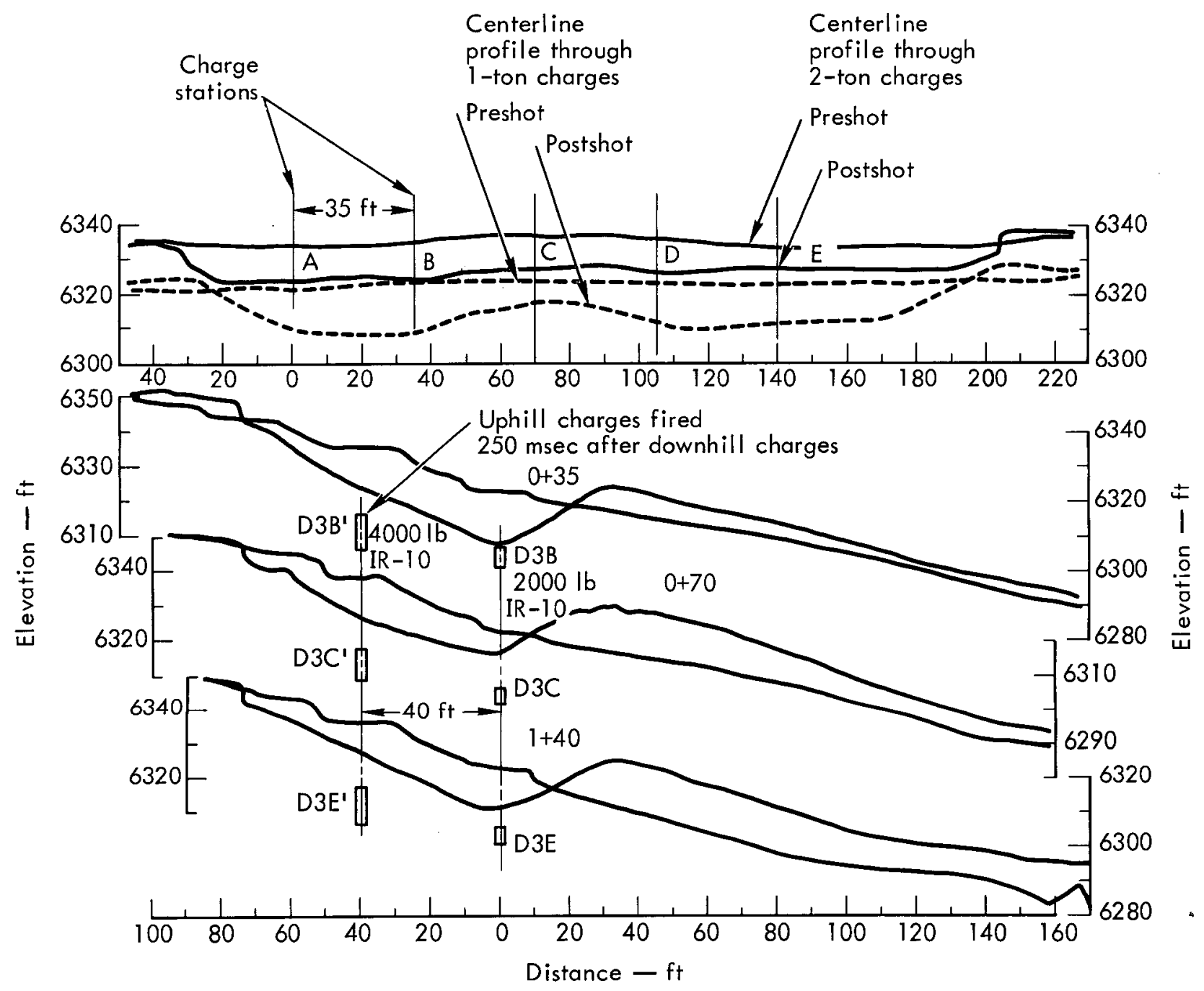

Fig. 18. Longitudinal profiles and cross sections of D3 crater.

charges was delayed $250 \mathrm{msec}$ after the detonation of the downslope row.

The D3 experiment also included an attempt to shape the uphill wall of the crater by means of a presplit plane. The $20-\mathrm{ft}$ deep presplit holes were 2.5 in. in diameter, spaced $2 \mathrm{ft}$ apart, and loaded with $0.25 \mathrm{lb}$ of dynamite per foot. The presplit holes were fired before the main charges and were located along the assumed true crater boundary.

Figure 19 is a photograph of the D3

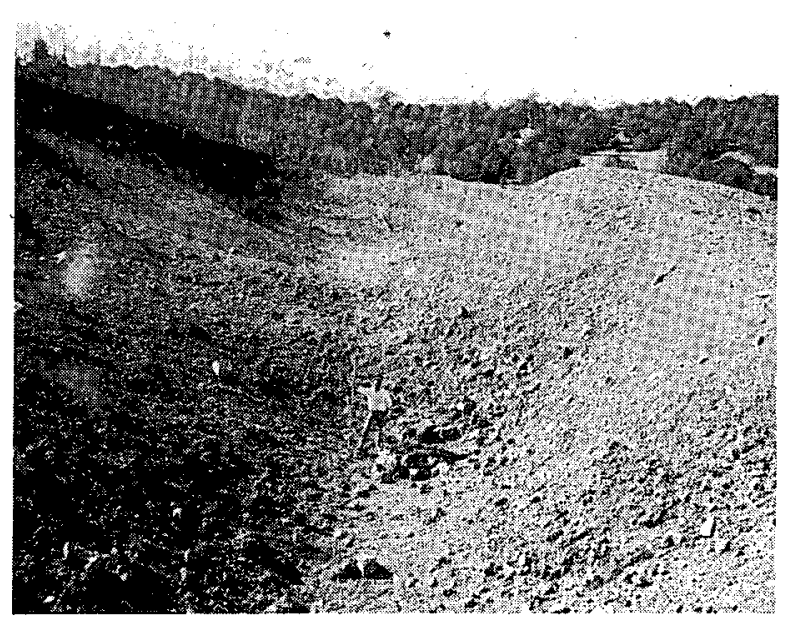
crater. The crater is broad and shallow, resembling the $\mathrm{D} 2$ crater in appearance. Fig. 19. D3 crater. 
The mound in the middle of the crater may have been the result of only partial detonation of a charge. That this occurred is simply a matter of speculation; however, the side-on high-speed film of the experiment did show a pronounced low point in the rising mound at this location.

The apparent crater volume per ton of explosive, averaged over the linear portion of the crater, is $9,040 \mathrm{ft}^{3} /$ ton. This unit volume was unexpectedly low in comparison to the average of $11,140 \mathrm{ft}^{3} /$ ton realized in the $\mathrm{C}$-series, especially in view of the reported high bubble energy of the explosive. As previously mentioned, the IR-10 explosive was surplus from another project, and it may have deteriorated during the 6 mo it was in storage although there is no test information to substantiate this hypothesis. Further, there is a major discrepancy in the values of bubble energy reported by the manufacturer. The original value of $1,130 \mathrm{cal} / \mathrm{g}$ is in Table 3 , and it is this value that was used in the design of $D 3$. After the experiment, a much lower value of bubble energy, approximately $400 \mathrm{cal} / \mathrm{g}$, was reported for this explosive. If the lower value is the correct one, then the charges were buried too deeply and spaced too far apart. It is interesting to note that, comparing the volume of the D3 crater to the average of $11,140 \mathrm{ft}^{3} /$ ton excavated by TD-2, the IR-10 would have a bubble energy of roughly $680 \mathrm{cal} / \mathrm{g}$.

It is possible that the delay time between the two rows was too long and that the interaction of ejecta from the two rows was detrimental to cratering efficiency. The high-speed film of the detonation, taken by a camera aimed along the alinement of the rows, suggested that the delay time probably was too long. The mound from the downhill row may have been too well developed at the time the second row of charges was detonated. The decision was made to use a shorter delay time between the rows of the followon D4 experiment.

The depth of the D3 crater, averaged over the entire linear portion of the crater, was $10.7 \mathrm{ft}$. The maximum depth was $15.5 \mathrm{ft}$ and the shallowest portion was $5.5 \mathrm{ft}$ deep. If the mound in the crater bottom is disregarded, then the average depth is about $12.5 \mathrm{ft}$.

The presplitting did not result in a smooth, planar face on the upslope wall of the crater, although portions of the presplit holes were visible near the surface. It is believed that the low strength of the rock and slumping prevented the formation of a clean wall. It appears that the presplit plane was located at the correct distance from the main charges because there was little or no disturbance of the ground surface beyond their location. It is possible that removal of the fallback would have revealed the existence of a presplit surface at depth, say $15 \mathrm{ft}$, but this was not done. There is still no reason to believe that presplitting cannot be used in conjunction with cratering detonations, but more experimentation is definitely needed.

Delayed Double Row-Charge (Railway Cut, D4)

The D4 experiment ${ }^{*}$ was designed to excavate a $400-\mathrm{ft}$ cut along the realinement of the Colorado and Wyoming

\footnotetext{
* Because of additional railway cuts excavated later, the D4 experiment is also referred to as RR1; i.e., the first railroad cut.
} 
Railroad. The terrain in the area of the cut was varying, with a portion of the cut along a gentle sidehill. Design depth of the cut ranged from 15 to $20 \mathrm{ft}$ and the required width at subgrade elevation was $46 \mathrm{ft}$. Conventional excavation of the cut would have required the removal of approximately $13,000 \mathrm{yd}^{3}$ of earth and rock. The location of the cut is shown in Fig. 5.

The explosive array consisted of two parallel rows of charges. The anticipated cross section and a plan view of the charge array are shown in Fig. 20. The

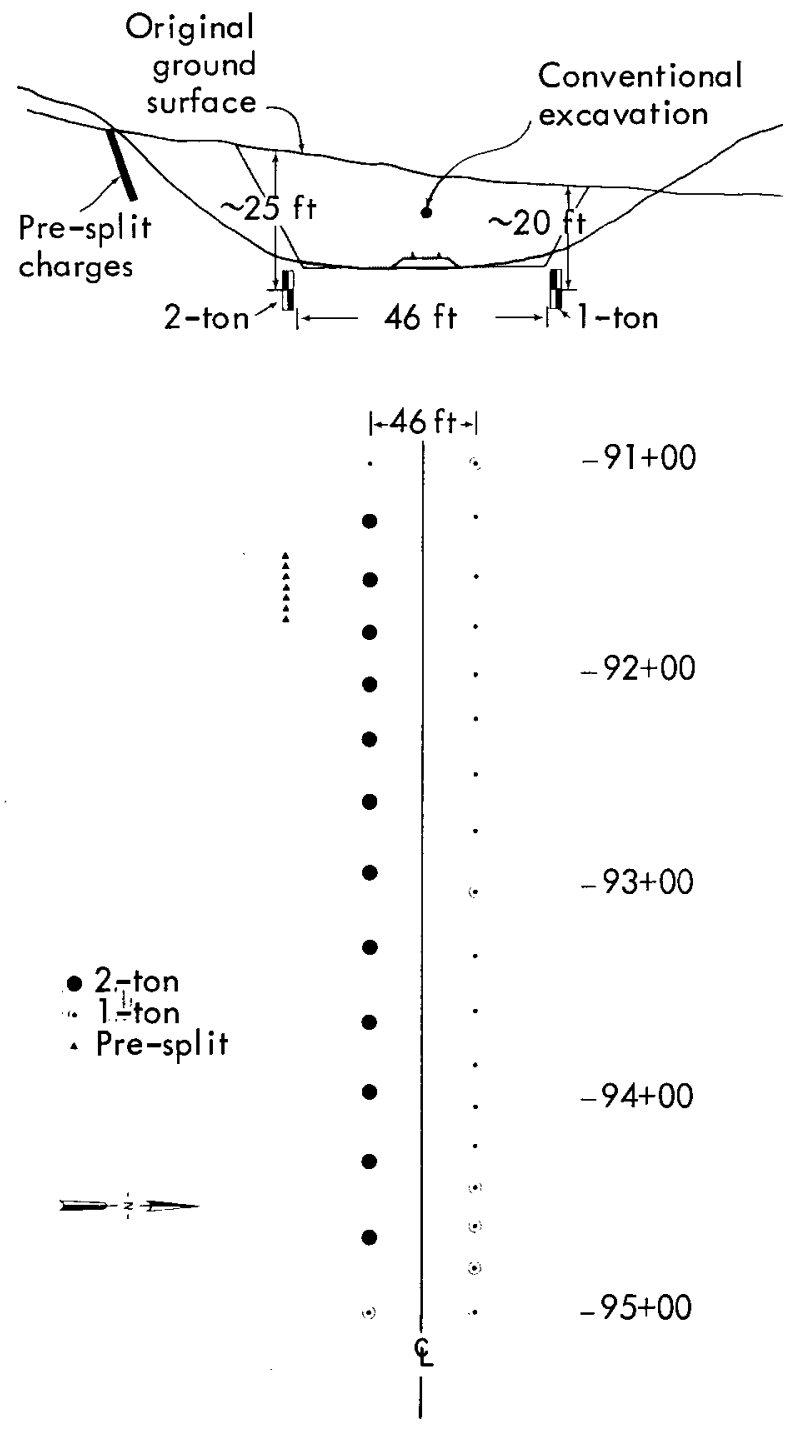

Fig. 20. Anticipated cross section and plan view of D4 experiment. north row consisted of eighteen 1 -ton charges and the south row consisted of twelve 2-ton and two 1-ton charges, a total of 32 separate charges and 44 tons of explosive. The rows were alined parallel to the railway centerline but were offset $23 \mathrm{ft}$ on both sides of the centerline. Each row was designed separately according to the terrain elevation along its alinement. A constant-yield (i. e., varying-enhancement) design was used for both rows.

In the varying enhancement design method, the spacing $\left(S / R_{a}\right)$ of the charges in a row is varied rather than their weight in order to accommodate varying depths of cut. The depth of cut is equated to the enhanced crater depth; i.e.:

depth of cut $=e D_{a}=\left(\frac{1.4}{S / R_{a}}\right)^{1 / 2} D_{a}$,

where $D_{a}$ is the depth of the single crater formed by the selected charge weight. A

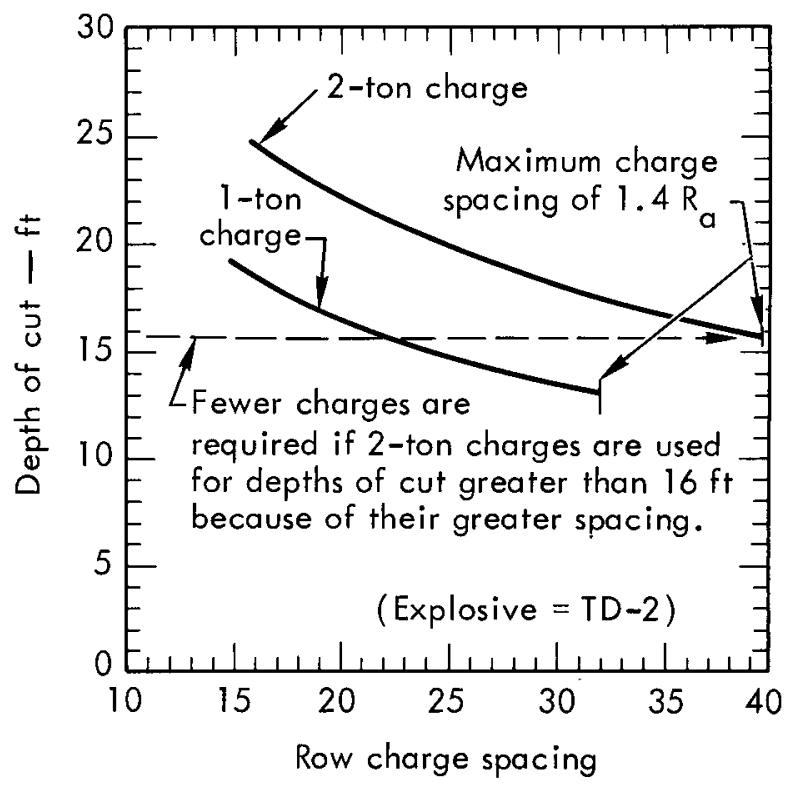

Fig. 21. Chart of charge spacing vs depth of cut for 1 - and 2-ton charges of TD-2 slurry in sandstone and shale. 
simple chart can be prepared showing the required charge spacing for a given charge weight and depth of cut. The chart used for designing the D4 cut is shown in Fig. 21. Two-ton charges were used wherever the depth of cut was greater than $16 \mathrm{ft}$ to minimize the number of drill holes required. As mentioned before in the discussion of the $\mathrm{C}$-series, the charges must be buried deeper as they are spaced closer together.

The separation between the rows was fixed at $46 \mathrm{ft}$ along the entire length of the cut. As a consequence of the fixed separation between rows, the row separation expressed in terms of the row-crater width varied with the depth of the cut. At the deepest portion of the cut the row separation was 1.45 times the average ${ }^{*}$ halfwidth of a single row crater [i.e., $1.45 \mathrm{~W}_{\mathrm{a}} / 2$ (average)], and at the shallowest portion the separation was $1.70 \mathrm{~W}_{\mathrm{a}} / 2$ (average). The charge spacing within each row varied from $0.90 \mathrm{R}_{\mathrm{a}}$ to $1.25 \mathrm{R}_{\mathrm{a}}$.

Table 10 contains a summary of the charge emplacement data for D4. Two methods were employed for drilling the emplacement holes for the explosive. The northern line of 1 -ton holes was drilled using an "underreamer." The procedure consisted of drilling an 18-in. pilot hole and expanding the bottom portion of the hole to 36 in. with expanding arms on the drill bit. The southern line of 2-ton holes was drilled to depth with a bucket auger at the full charge-cavity diameter of 30 in. The holes were loaded by pumping the slurry directly into the

"By "average" is meant the mean halfwidth of the row craters formed by the row of 1-ton charges and the row of 2-ton charges. emplacement hole from the mixing truck. A delay of approximately $150 \mathrm{msec}$ was introduced between the detonation of the two rows, with the northern (1-ton) row being fired first.

The development of the mound and ejecta is shown several seconds after detonation in Fig. 22, and Fig. 23 shows

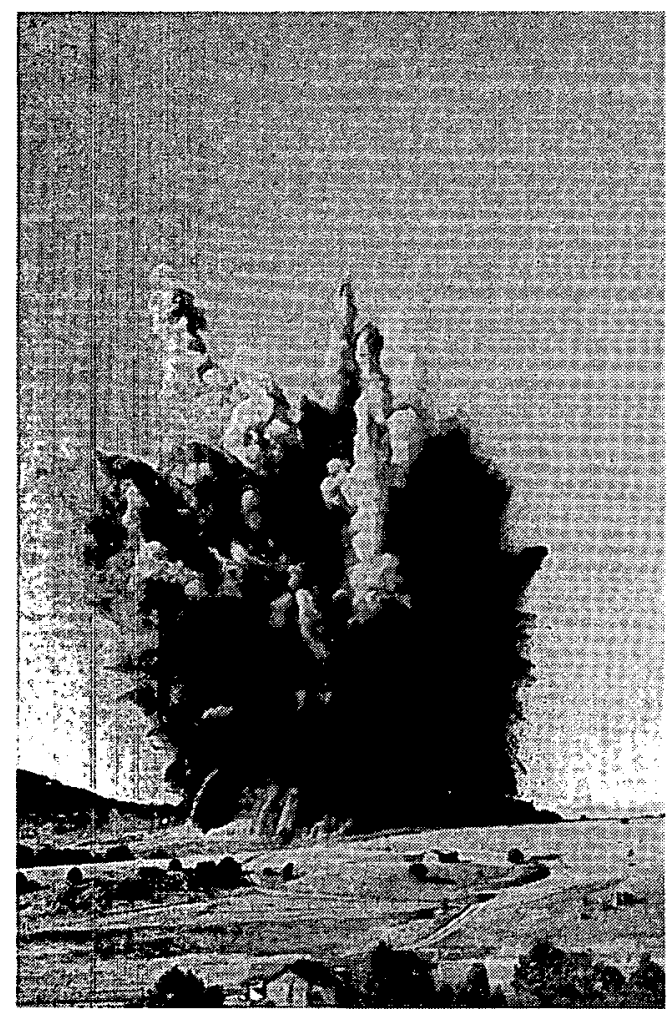

Fig. 22. D4 detonation.

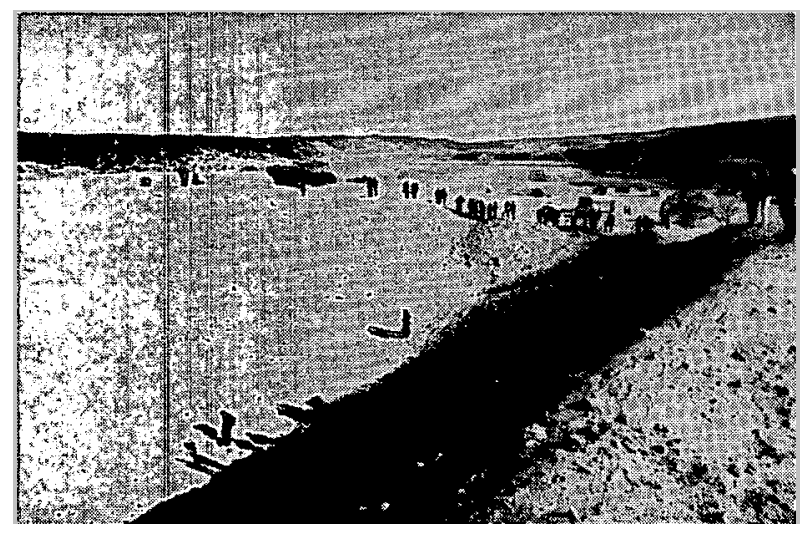

Fig. 23. D4 crater viewed from west to east along center line of railroad. 
Table 10. D4 charge emplacement summary.

\begin{tabular}{|c|c|c|c|c|c|c|}
\hline $\begin{array}{l}\text { Charge } \\
\text { number }\end{array}$ & Station & $\begin{array}{l}\text { Hole } \\
\text { depth } \\
\text { (ft) }\end{array}$ & $\begin{array}{l}\text { Depth to } \\
\text { top of } \\
\text { charge } \\
\text { (ft) }\end{array}$ & $\begin{array}{l}\text { Charge } \\
\text { weight } \\
\text { (tons) }\end{array}$ & $\begin{array}{c}\text { Charge } \\
\text { height } \\
\text { (ft) }\end{array}$ & $\begin{array}{c}\mathrm{DOB} \\
(\mathrm{ft})\end{array}$ \\
\hline \multicolumn{7}{|c|}{ A. South Line } \\
\hline D4 $A^{\prime}$ & $91+00$ & 21.3 & 18.0 & 1 & 3.3 & 19.7 \\
\hline D4 $B^{\prime}$ & $91+27$ & 26.2 & 19.8 & 2 & 6.4 & 22.0 \\
\hline $\mathrm{D} 4 \mathrm{C}^{\prime}$ & $91+55$ & 29.6 & 20.5 & 2 & 9.1 & 25.0 \\
\hline $\mathrm{D} 4 \mathrm{D}^{\prime}$ & $91+80$ & 30.3 & 20.2 & 2 & 10.1 & 25.2 \\
\hline $\mathrm{D} 4 \mathrm{E}^{\prime}$ & $92+05$ & 30.3 & 20.2 & 2 & 10.1 & 25.2 \\
\hline $\mathrm{D} 4 \mathrm{~F}^{\prime}$ & $92+31$ & 28.3 & 19.2 & 2 & 9.1 & 23.7 \\
\hline$D 4 G^{\prime}$ & $92+60$ & 27.2 & 18.3 & 2 & 8.9 & 22.8 \\
\hline $\mathrm{D} 4 \mathrm{H}^{\prime}$ & $92+93$ & 26.3 & 20.1 & 2 & 6.2 & 23.2 \\
\hline D4 $\mathrm{I}^{\prime}$ & $93+28$ & 26.4 & 17.4 & 2 & 9.0 & 21.9 \\
\hline D4 $J^{\prime}$ & $93+63$ & 25.9 & 14.5 & 2 & 11.1 & 20.0 \\
\hline $\mathrm{D}^{\prime} \mathrm{K}^{\prime}$ & $93+96$ & 27.2 & 16.7 & 2 & 10.5 & 21.9 \\
\hline D4L' & $94+29$ & 26.5 & 16.4 & 2 & 10.1 & 21.4 \\
\hline D4 M' & $94+65$ & 24.2 & 12.8 & 2 & 11.4 & 18.5 \\
\hline $\mathrm{D} 4 \mathrm{~N}^{\prime}$ & $95+00$ & 19.8 & 14.0 & 1 & 5.8 & 16.9 \\
\hline \multicolumn{7}{|c|}{ B. North Line } \\
\hline D4A & $91+00$ & 20.7 & 13.9 & 1 & 6.8 & 17.3 \\
\hline D4B & $91+26$ & 19.0 & 15.5 & 1 & 3.5 & 17.2 \\
\hline $\mathrm{D} 4 \mathrm{C}$ & $91+54$ & 22.2 & 18.6 & 1 & 3.6 & 20.4 \\
\hline $\mathrm{D} 4 \mathrm{D}$ & $91+78$ & 22.6 & 18.7 & 1 & 3.9 & 20.6 \\
\hline $\mathrm{D} 4 \mathrm{E}$ & $92+00$ & 23.1 & 18.3 & 1 & 4.8 & 20.7 \\
\hline $\mathrm{D} 4 \mathrm{~F}$ & $92+22$ & 23.4 & 17.4 & 1 & 6.0 & 20.4 \\
\hline $\mathrm{D} 4 \mathrm{G}$ & $92+47$ & 21.0 & 15.4 & 1 & 5.6 & 18.2 \\
\hline $\mathrm{D} 4 \mathrm{H}$ & $92+74$ & 20.3 & 15.5 & 1 & 4.8 & 17.9 \\
\hline D4I & $93+03$ & 20.6 & 15.9 & 1 & 4.7 & 18.2 \\
\hline D4 J & $93+32$ & 20.1 & 16.4 & 1 & 3.7 & 18.2 \\
\hline $\mathrm{D} 4 \mathrm{~K}$ & $93+59$ & 20.3 & 16.3 & 1 & 4.0 & 18.3 \\
\hline $\mathrm{D} 4 \mathrm{~L}$ & $93+83$ & 23.3 & 18.8 & 1 & 4.5 & 21.0 \\
\hline D4 M & $94+03$ & 24.2 & 20.6 & 1 & 3.6 & 22.4 \\
\hline $\mathrm{D} 4 \mathrm{~N}$ & $94+22$ & 23.3 & 21.0 & 1 & 2.3 & 22.1 \\
\hline $\mathrm{D} 4 \mathrm{O}$ & $93+41$ & 23.9 & 19.4 & 1 & 4.5 & 21.6 \\
\hline D4P & $94+60$ & 23.6 & 19.0 & 1 & 4.6 & 21.3 \\
\hline $\mathrm{D} 4 \mathrm{Q}$ & $94+79$ & 23.8 & 18.0 & 1 & 5.8 & 20.9 \\
\hline $\mathrm{D} 4 \mathrm{R}$ & $95+00$ & 22.9 & 18.0 & 1 & 4.9 & 20.4 \\
\hline
\end{tabular}




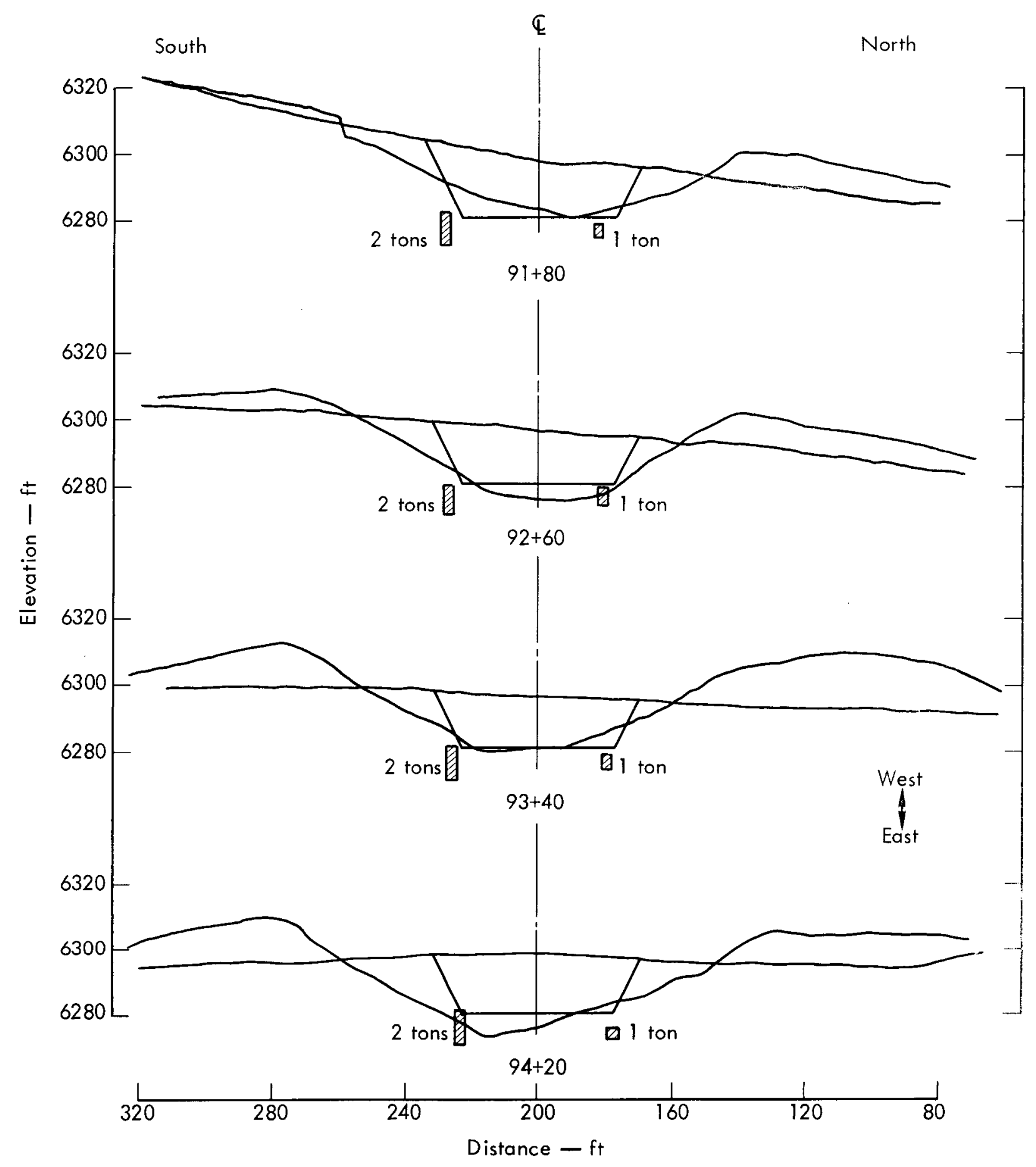

Fig. 24. Cross sections of D4 railway cut showing comparison between crater and cut excavated by conventional methods.

the resulting crater. Four cross sections through the crater are shown in Fig. 24.

A total volume of $18,000 \mathrm{yd}^{3}$ of material was ejected by the blast, which is equivalent to a unit volume of $11,000 \mathrm{ft}^{3} /$ ton of explosive. This value is nearly the same as the average for the three simultaneous $\mathrm{C}$-series row craters, and indicates that the delayed double row was 
very efficient, particularly when compared to the unit volume of only $8,900 \mathrm{ft}^{3} /$ ton excavated by the simultaneously detonated double row, $\mathrm{C} 6$.
Chapter 6 contains a description of the postshot work required to transform the D4 crater into a useful railway cut.

\section{Chapter 4. Seismic Measurements}

This chapter presents a summary of the seismic ground motion program. The objectives were to collect and to compare data on the seismic signals generated by the wide variety of cratering detonations in the project. Only a brief analysis of peak motions is presented in this chapter; Ref. 13 contains a more detailed treatment of the data.

\section{SCOPE}

The bulk of the information was recorded by personnel of the Soils Division of the USAE Waterways Experiment Station (WES). Conjunctive studies of the structural response of the intake tower and surveys of several close-in residential buildings were performed by the firm of

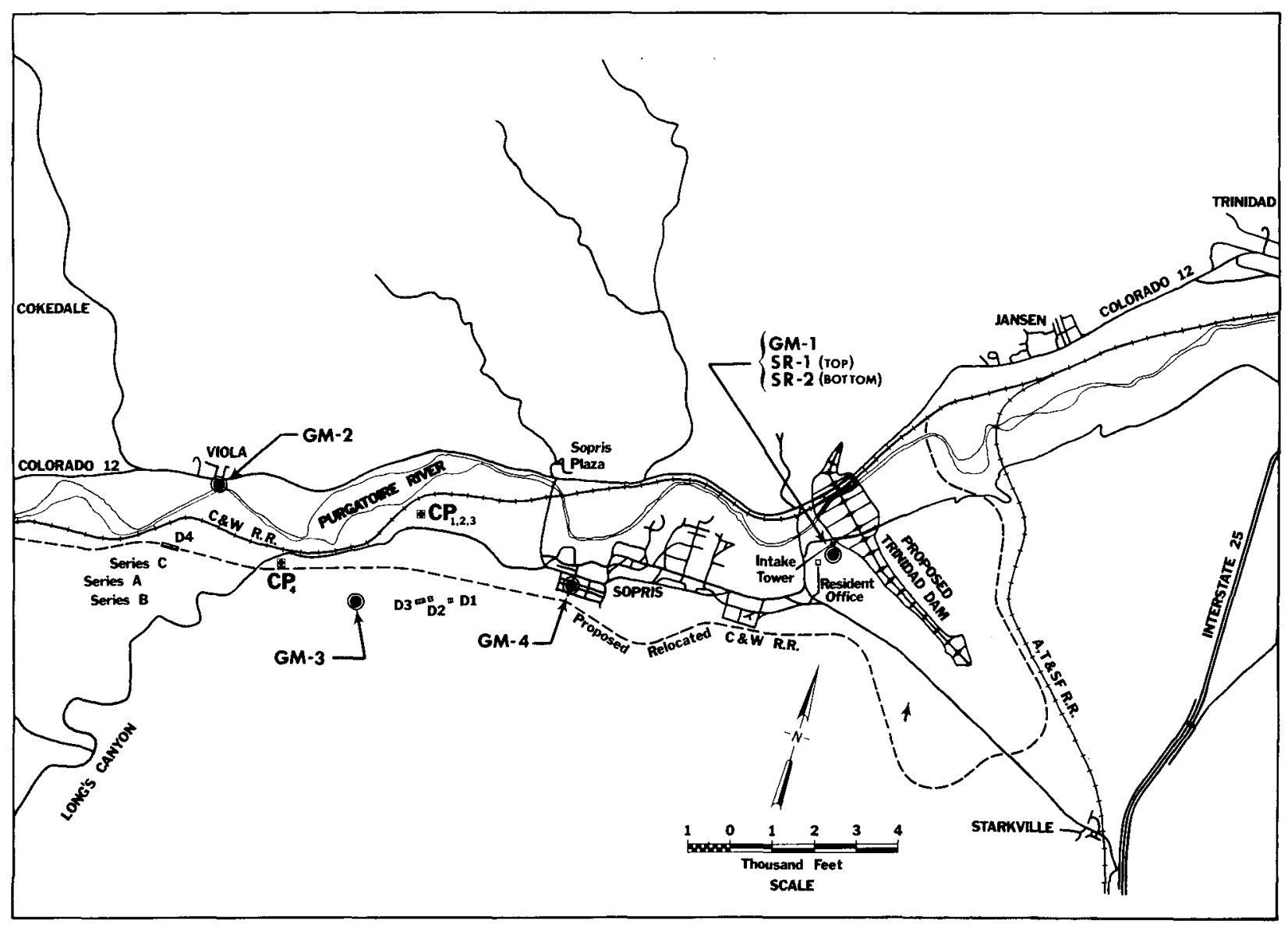

Fig. 25. Locations of seismic monitoring stations during Project Trinidad. 
John A. Blume and Associates of San Francisco. A supplemental program of monitoring building response was carried out by the Special Projects Party of the National Ocean Survey (Las Vegas) during the D1, D2, and D3 detonations. ${ }^{12}$ This work was performed at the request of the Nevada Operations Office of the AEC.

Initially, five WES recording stations were established, three for ground motion and two for the structural response of the intake tower. All detonations from B1 through $\mathrm{C} 6$ were monitored at these five locations. Only three stations were monitored by WES during the D-series, two of which were at the intake tower. All recording locations are shown in Fig. 25 and described in Table 11.

Several residential buildings in the town of Viola, approximately 2,500 ft from the main experimental area, were extensively surveyed for the development of new plaster cracks and the widening of existing cracks.

Each WES recording station consisted of three velocity transducers in a triaxial array with the horizontal components oriented radially and transversely with respect to the shot locations. The velocity transducers were moving-coil geophones

Table 11. Locations of seismic recorders, Project Trinidad.

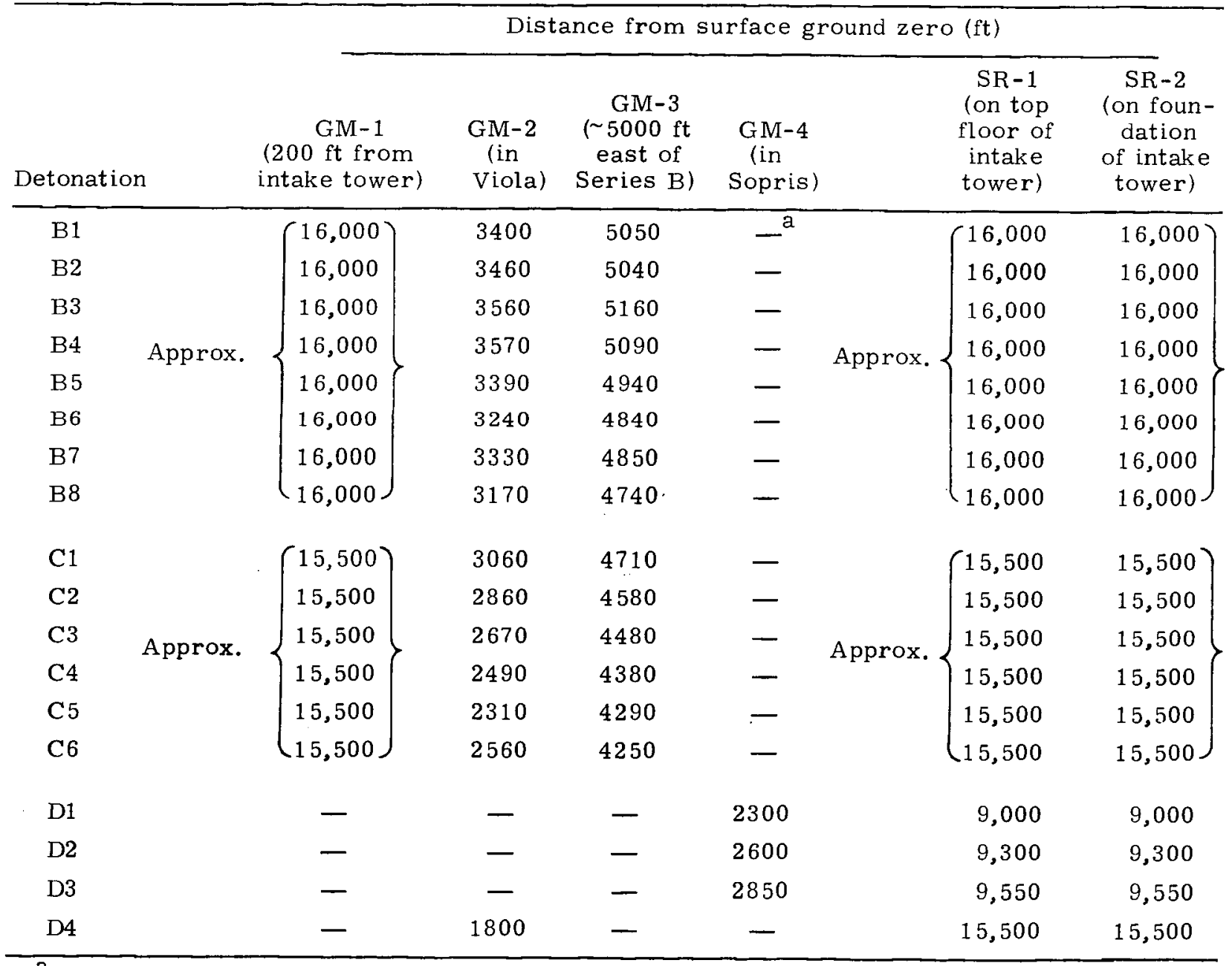

\footnotetext{
${ }^{a}$ Dashes denote that station was not recorded.
} 
having a natural frequency of $1 \mathrm{~Hz}$ and $70 \%$ critical damping. The geophones were embedded in modeling clay in order to attach them to the rock or structure at each location. The signals were recorded on direct-write oscillographs. A semipermanent installation was set up to record signals at and near the intake tower, and portable recorders were used at the other locations. Radio communication was maintained between each recorder and Project Control at detonation times. The NOAA instrumentation, which is described in Ref. 12

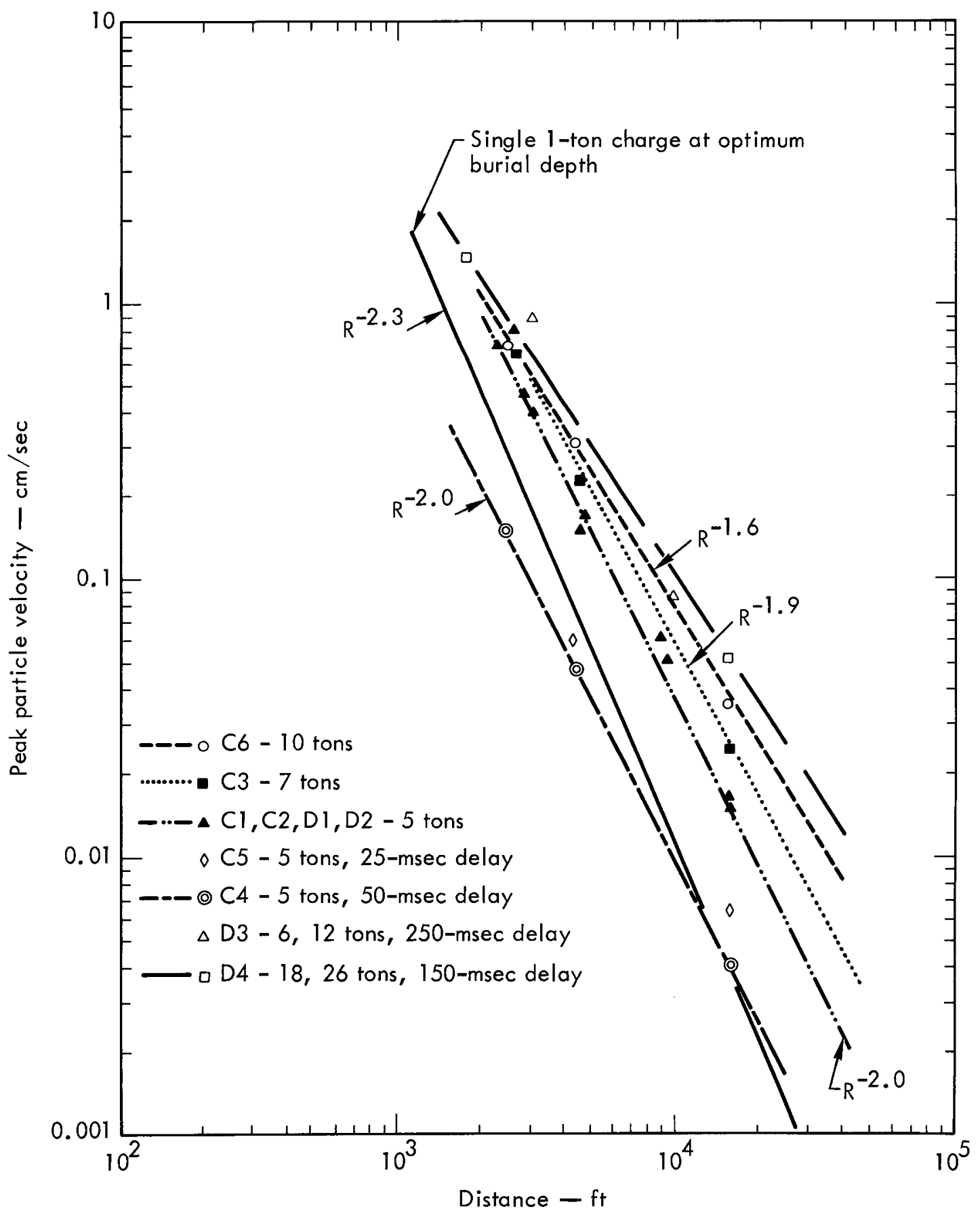

Fig. 26. Peak ground motion amplitudes vs distance. 
also consisted of velocity transducers arrayed triaxially.

\section{RESULTS}

The data collected during this program are tabulated in Appendix C. Motions have been expressed in terms of zero-topeak amplitudes, and an attempt has been made to report separately the amplitudes for compressional, shear, and surface waves for all events except the B series.

The peak amplitudes recorded at the ground motion stations are presented graphically as a function of distance in Fig. 26. The straight-line representation of the data on a $\log -\log$ plot is equivalent to an inverse power law relationship of the form:

$$
\mathrm{V}=\mathrm{KW}^{\mathrm{p}_{\mathrm{R}}}{ }^{-\mathbf{n}}
$$

where

$$
\begin{aligned}
\mathrm{V} & =\text { peak particle velocity } \\
\mathrm{K} & =\text { a constant } \\
\mathrm{W} & =\text { charge weight } \\
\mathrm{R} & =\text { distance from the detonation } \\
\mathrm{p} \text { and } \mathrm{n}= & \text { empirically determined } \\
& \text { exponents. }
\end{aligned}
$$

This is the most common form of equation for empirically describing the variables involved, but it is not a physical description of attenuation. 14

A number of significant results are apparent from an inspection of Fig. 26. It will be noted that the rate at which amplitudes attenuate with distance decreases as the total yield of the detonation increases. This is probably because of the relatively greater low frequency content of the siesmic signal with increasing source size; i.e., increasing charge weight, and the fact that attenuation is proportional to frequency.

The observation that the attenuation of peak amplitudes with distance depends upon total charge weight also means that the apparent weight-scaling of amplitudes will depend on the distance from the detonation. The weight scaling varied from about 0.45 at $2,500 \mathrm{ft}$ to about 0.95 at $15,000 \mathrm{ft}$. A statistical analysis of all the seismic information from Project Trinidad, including the data from the Middle Course II Series, is the subject of Ref. 13. In this report the peak amplitudes were successively adjusted for weight-scaling and depth of burial until all the data points had a least squares best fit to a straight line on $\log -\log$ paper. The final best-fit equation through all the data points, which was derived in Ref. 13, is:

$$
\begin{aligned}
V=6.74 \times 10^{5} \mathrm{~W}^{0.65} \mathrm{R}^{-1.95} \\
\times \exp [0.06(\mathrm{DOB}-20)]
\end{aligned}
$$

where

$$
\begin{aligned}
\mathrm{V}= & \text { peak particle-velocity, in } \\
& \mathrm{cm} / \mathrm{sec}, \\
\mathrm{W}= & \text { largest instantaneously deto- } \\
& \text { nated charge weight, in tons, } \\
\mathrm{R}= & \text { distance, in } \mathrm{ft}, \\
\text { DOB }= & \text { scaled depth of burst, in } \\
& \mathrm{ft} / \mathrm{ton}^{1 / 3}
\end{aligned}
$$

This equation can be used to predict peak amplitudes at the Trinidad site within a factor of two for charge weights from 1 to 100 tons, and for distances from 1 to $10 \mathrm{mi}$.

The peak particle velocities were lower than had been predicted before the beginning of the test program. The initial preshot predictions were based on previous experience with similar charge weights at other sites; however, the observed peak 
amplitudes were lower by a factor of approximately five. This is believed to be primarily due to the weak and stratified nature of the rock.

A significant result of the seismic program is the marked reduction of ground shock when delays are used between charges in a row. Although this effect was well known from the extensive use of delays in quarrying, it was not known whether the technique could be used for larger scale cratering detonations. Inspection of Fig. 26 will show that the delayed five-charge rows generated seismic amplitudes virtually identical to a single 1 -ton charge. This is approximately a three-fold reduction of the seismic signal generated by a simultaneously detonated row of five charges. The relatively longer delay time of $50 \mathrm{msec}$ appears to have been only slightly more effective in diminishing ground shock than the 25-msec delay; however, the shorter delay was definitely advantageous from the standpoint of cratering efficiency.

The results of monitoring close-in residential structures was disappointing in the sense that no damage was observed. The peak ground motion amplitude re- corded at a building was $1.5 \mathrm{~cm} / \mathrm{sec}$ in Viola, and careful scrutiny of plaster walls failed to disclose any new cracks or the widening of pre-existing ones.

The response of the intake tower was analyzed by John A. Blume and Associates to establish ground motion criteria that would avoid detectable damage to the structure. 15 The tower is a massive reinforced concrete structure about $180 \mathrm{ft}$ high. Its fundamental natural period of oscillation is about $0.6 \mathrm{sec}$. Because the response of the tower to ground motion depends on the frequency content of the ground motion, and because the spectrum of ground motion depends on both charge weight and distance, it is not possible to state a simple set of criteria. For a relatively large detonation, say 300 tons, a safe level of ground motion would be about $3.5 \mathrm{~cm} / \mathrm{sec}$; however, for smaller charges of the order of 5 tons, the safety criterion would be 20 to $30 \mathrm{~cm} / \mathrm{sec}$ of ground motion at the base of the tower. Peak motion recorded at the base of the tower was approximately $0.08 \mathrm{~cm} / \mathrm{sec}$, and the maximum motion recorded at the top of the tower was about $0.18 \mathrm{~cm} / \mathrm{sec}$.

\section{Chapter 5. Airblast Measurements}

\section{SCOPE}

The wide variety of cratering experiments in this project provided an excellent opportunity to acquire airblast information useful for extending the capability to predict airblast from explosive excavation projects in general. Another aspect of the airblast program was instrumentation of various areas as a legal safeguard. Airblast overpressures were measured at ranges of a few hundred feet to several miles from the detonations.

Buried detonations in unsaturated rock give rise to two distinct airblast pressure pulses. The initial or ground-shockinduced pulse is caused by the upward spall velocity of the ground surface above 
the explosion. This is followed by the gas-vent-induced pulse when the cavity gas vents to the surrounding atmosphere. The gas-vent pulse is relatively strong for shallow detonations, but is rapidly suppressed with increasing scaled depth of burial; it also lags further behind the ground-shock-induced pulse for deeper detonations. Ground shock airblast becomes dominant for deep explosions.

The amplitude of either airblast pulse is a function of range from the experiment location, type and weight of explosive, depth of burial, rock type, and the ambient atmospheric conditions. Past experience has shown that peak pressure at intermediate distances generally attenuates as $R^{-1.0}$ to $R^{-1.3}$, where $R$ is the dis tance. Further, it is possible to adjust for charge size and for differences in ambient air pressure by simple scaling laws. The remaining factors; i.e., depth of burial, medium, and explosive type, are the chief influences on airblast from single-charge explosions that can be examined experimentally. Previous experiments have investigated airblast from TNT and nuclear explosives in a variety of soil and rock media.

\section{RESULTS}

Because of the volume and complexity of the data collected, only a few selected results of the airblast program are presented in this chapter. A complete summary of the observed peak overpressure is tabulated in Appendix $D$, and an analysis of this information accompanies the data. Reference 16 is a thorough analysis of all the airblast data.
Some of the more relevant information is presented graphically in Fig. 27, in which observed peak overpressures for selected events have been plotted against distance. Figure 27 is intended to provide a comparison between peak overpressures from a variety of detonations. Airblast amplitudes from two 1-ton detonations, Detonation B6 near optimum depth of burial and a 1-ton surface burst, are plotted to provide a frame of reference for the row-charge data. The row-charge data are from a simultaneously detonated five-charge row (C1), from a delayed five-charge row (C5), and from the delayed double-row D4 detonation. Except for the surface burst, lines with a slope of $R^{-1.2}$ have been drawn through the data points. The overpressures plotted in Fig. 27 are those recorded perpendicular to the sides of the rows, these pressures always being higher than those recorded off the ends (axial direction) of the row charges. With the exception of the data for B6, the peak pressures plotted were generated by the gas vent.

To put the plotted airblast amplitudes into some perspective, Table 12 contains criteria for damage, a matter of direct interest for explosive excavation projects.

There are several significant aspects to the information in Fig. 27. The introduction of delays between the charges in a row substantially reduces the airblast generated, as is seen by comparing $\mathrm{C} 1$ to $\mathrm{C} 5$. The detonation of the array of 44 tons of explosive in D4 generated airblast pulses that were generally lower in amplitude than those generated by a 1 -ton surface burst. However, one of the recordings for D4 indicates an overpressure that approaches a 1-ton surface 


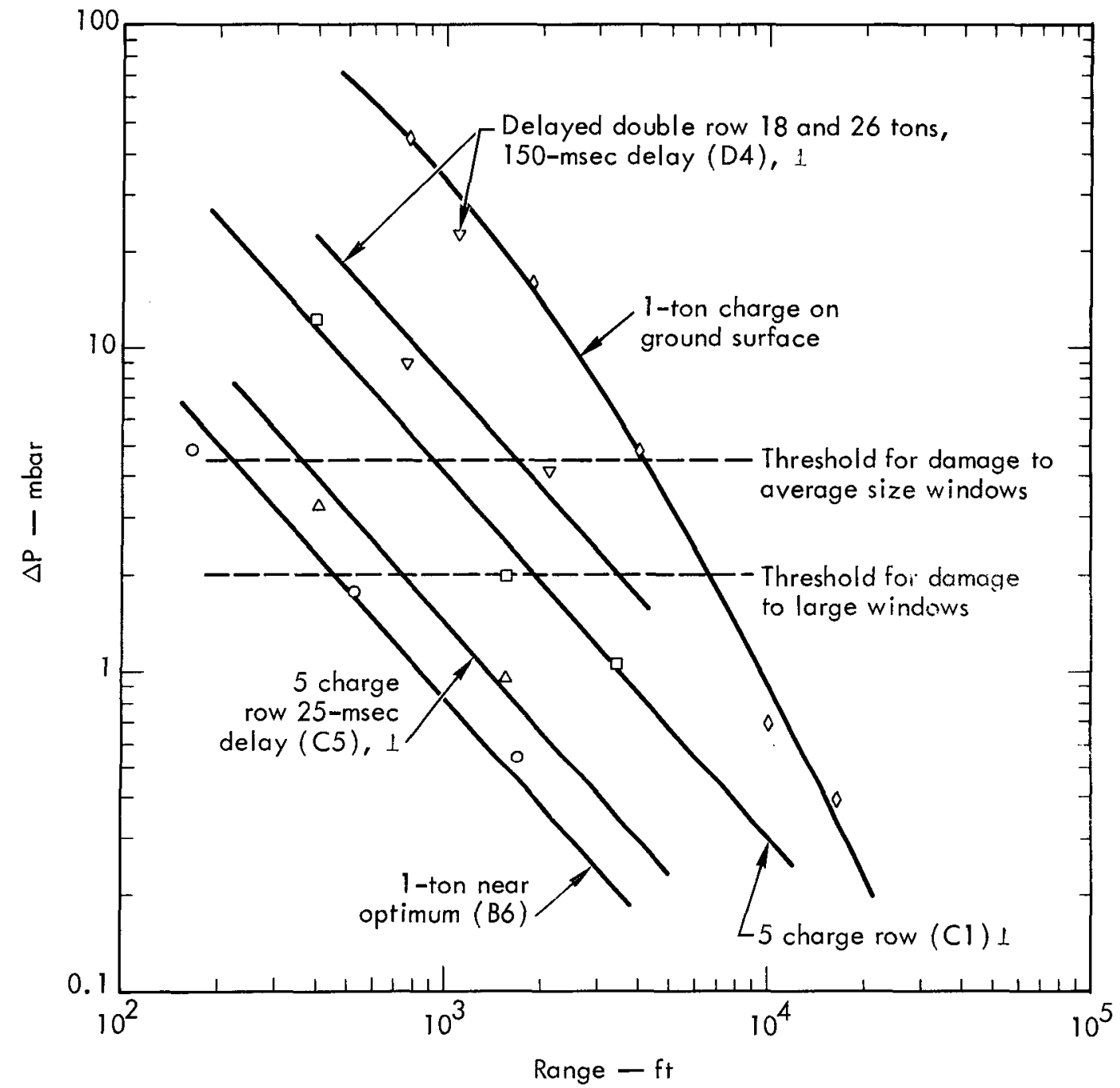

Fig. 27. Peak airblast overpressures for selected Project Trinidad detonations.

Table 12. Airblast damage criteria.

\begin{tabular}{cc}
$\begin{array}{c}\text { Overpressure, } \\
\text { (mbar) }\end{array}$ & Degree of damage \\
\hline 2 & $\begin{array}{c}\text { Possible window damage, particularly } \\
\text { to large store windows. } \\
\text { Some damage to large plate glass } \\
\text { windows can be expected. } \\
\text { Some damage to average size windows } \\
\text { can be expected. } \\
\text { Extensive damage to windows; probable } \\
\text { damage to average wooden doors. } \\
\text { Most small casement windows smashed. } \\
40\end{array} \quad$ Structural damage possible. \\
\hline
\end{tabular}

burst. This point is plotted in Fig. 27, and is attributed to reinforcement of the gas vent pulse from one of the two rows by the ground shock pulse from the other.
This is pointed out to illustrate the manner in which airblast pulses from arrays of charges can interact, and the fact that airblast is, in general, difficult to predict.

No window pane damage was reported for these detonations, although the nearest buildings were only 2,500 ft away. Figure 27 shows that the threshold for damage to small windows corresponds to a distance of approximately 1,000 ft from a fivecharge row such as $\mathrm{C} 1$. At this distance, there is probably a greater probability of damage from rock missiles than from airblast. 


\section{Chapter 6. Engineering Studies of D4 Crater}

\section{INTRODUCTION}

An intensive postshot investigation of the D4 crater (RR1) was conducted to determine the engineering properties of the fallback, and to determine the shaping required to bring the crater to design configuration. The investigations consisted of:

- Trenching and weighing a portion of the fallback to determine the mass density

- Applying the point-count technique ${ }^{17}$ to determine the particle gradation of the fallback

- Drilling, coring, and using the borehole camera to locate the limits of the fallback and rupture zones

- Shaping the crater by bringing the bottom to grade and dressing the slopes

- Compacting the fallback with a heavy, vibratory compactor to measure induced settlements

- Testing for the mechanical properties of the material at the University of California Richmond Laboratory. (This portion of the program, reported in Appendix E, consisted of an accurate determination of particle gradation, determining the strength and compressibility characteristics of the fallback, and ascertaining the validity of modeling a heterogeneous material of this type.)

\section{ON-SITE INVESTIGATIVE PROGRAMS}

Figure 28 shows the location of the field programs in and around the crater.
MASS DENSITY AND BULKING FACTOR

Immediately after the D4 detonation, a trench was excavated in the western portion of the crater to determine the mass density of undisturbed fallback. A relatively level area, judged to be representative of the entire crater, was selected for trenching. The front-loader used for trenching was guided with care to preclude unnecessary disturbance to the fallback. The material was removed, loaded on 5-ton dump trucks, and weighed. The volume of the material removed was determined by a detailed survey of the resulting trench.

The fallback removed from the trench weighed $372,350 \mathrm{lb}$, and the volume of the trench was $2894.4 \mathrm{ft}^{3}$, resulting in a mass density of $128.6 \mathrm{lb} / \mathrm{ft}^{3}$. The bulking factor ${ }^{*}$ of the fallback can be computed by comparing this density to that of the undisturbed rock. Laboratory tests of the country rock showed an average density of $156.3 \mathrm{lb} / \mathrm{ft}^{3}$, thus yielding a bulking factor of 1.22 , a value which is consistent with data from similar experiments. ${ }^{18}$

\section{FIELD DETERMINATION OF} PARTICLE GRADATION

Because of the large dimensions of the coarse particles of the rubble from a cratering explosions, the initial particle gradation was determined by a statistical

\footnotetext{
The bulking factor is the ratio between the in situ density of the country rock determined by coring and the mass density of the fallback. It is a valuable parameter in determining the postshot properties, balancing of cuts and fills, and estimating earth and rock moving production rates. 20,21
} 


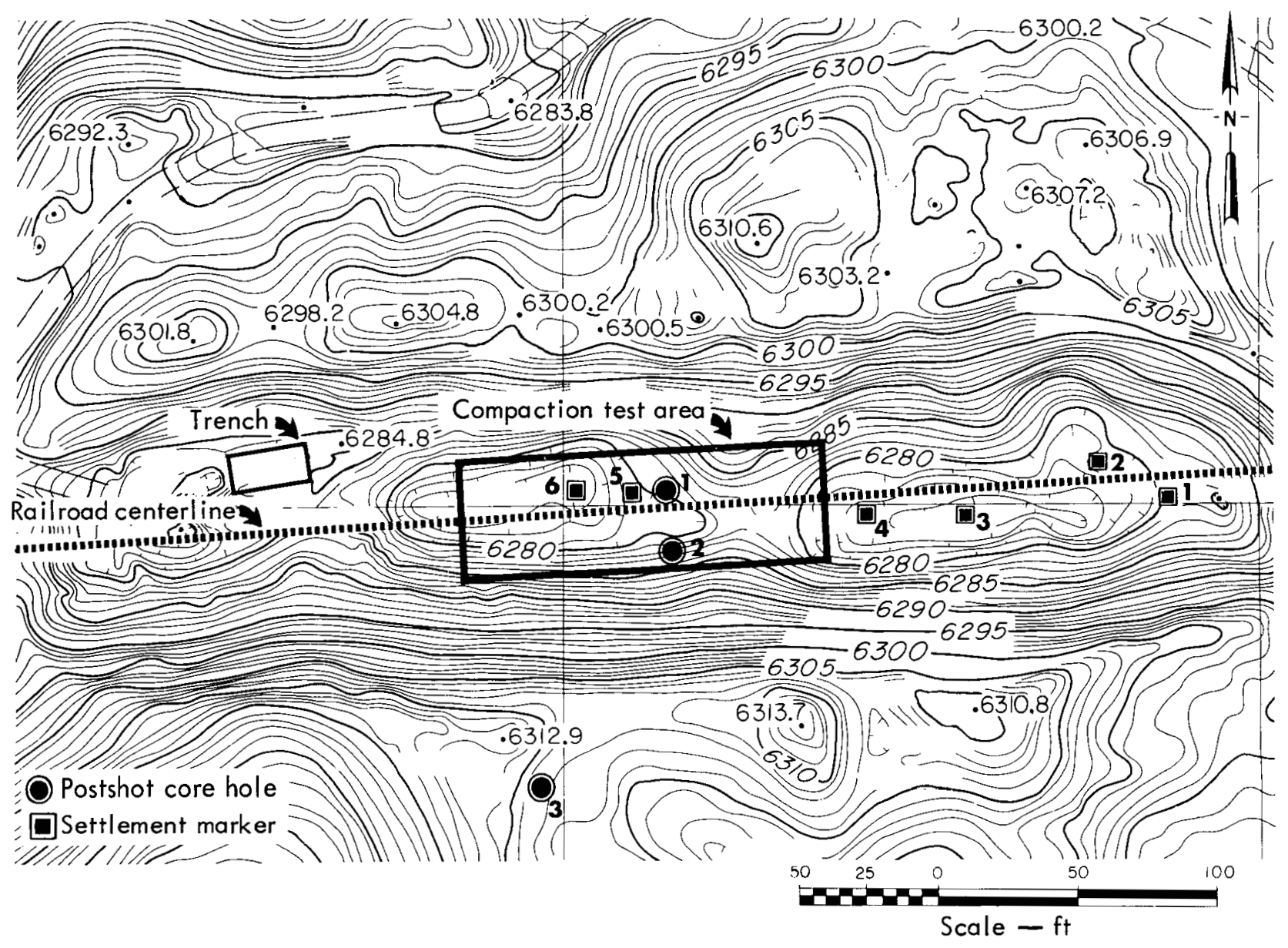

Fig. 28. Map of D4 crater showing location of postshot engineering investigations.

technique developed by Anderson, ${ }^{17}$ based on earlier work by Wolman. ${ }^{19}$ Because Anderson's technique was originally developed for nuclear detonations, which produce considerably large rock fragments, it was necessary to modify his technique. The dimensions of those particles which could be measured were obtained as specified by Anderson. In addition, representative samples of the fines were collected, air dried, and sieved in the normal fashion. The two methods can be then combined to produce a single curve; the lower limit of the point-count is faired into the upper limit of the sieving.

"Only those particles below a conveniently measurable size were counted during the sieving.
The gradation curves obtained at both ends of the railroad cut are shown in Appendix $\mathrm{E}^{*}$ where they are compared with carefully sieved samples obtained at the University of California. Results of the field technique are considered to be satisfactory and reasonable approximations of the actual grain-size distribution.

DRILLING, CORING, AND BOREHOLE PHOTOGRA PHY

Continuously cored holes were drilled to establish the limits of the fallback and rupture zones. Borehole photography was used to determine the extent of blastinduced fracturing.

Figure E1. 
Three NX core holes were drilled in the cratered area as shown in Figs. 28 and 29. Holes 1 and 2 were located at the bottom of the crater and hole 3 was located on the apparent crater lip, $100 \mathrm{ft}$ from the centerline. The holes were located approximately at mid-crater.

Analysis of the core indicated $7 \mathrm{ft}$ of fallback in Holes 1 and 2, a depth that contrasts with the $2 \mathrm{ft}$ of fallback observed in the west end where the trench was excavated. Further investigations indicated 1 to $2 \mathrm{ft}$ of fallback in the low area on the east end of the crater. This variation in the thickness of the fallback represents the presence of mounds in the bottom of the crater that appear to be randomly distributed.

The extent of blast-induced fracturing was determined from an examination of the core and from borehole photographs. The rock was highly fractured to depths of 16 to $18 \mathrm{ft}$ below the ground surface at Holes 1 and 2. No blast-induced fracturing could be observed at Hole 3 . Outlining the boundary of blast-induced fracturing shown in Fig. 30 was difficult because of the already fractured and weak nature of the country rock.

\section{SHA PING OF RAILROAD CUT}

Earthwork was required to shape the crater into its final design configuration; i.e., ready to accept subbase, ballast, and track. This work consisted of daylighting the ends of the crater, scaling the slopes, and leveling the bottom to subgrade elevation. A bulldozer with ripper accomplished most of the earthmoving.

Operations began with the daylighting of the east end of the crater. The loose

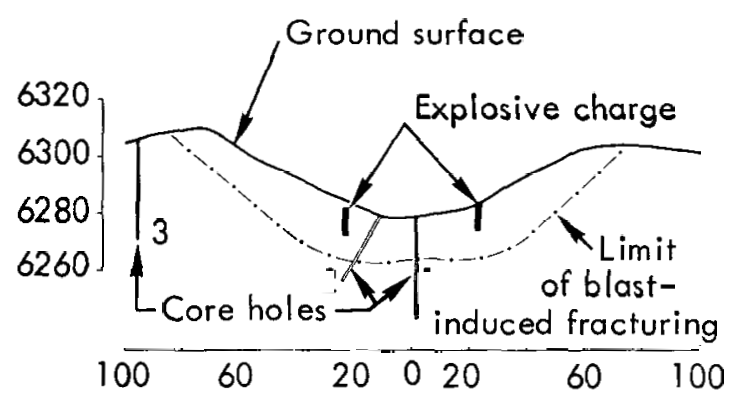

Fig. 29. Location of core holes in D4 crater and extent of blastinduced fracturing (cross section through Station $93+00$ ).

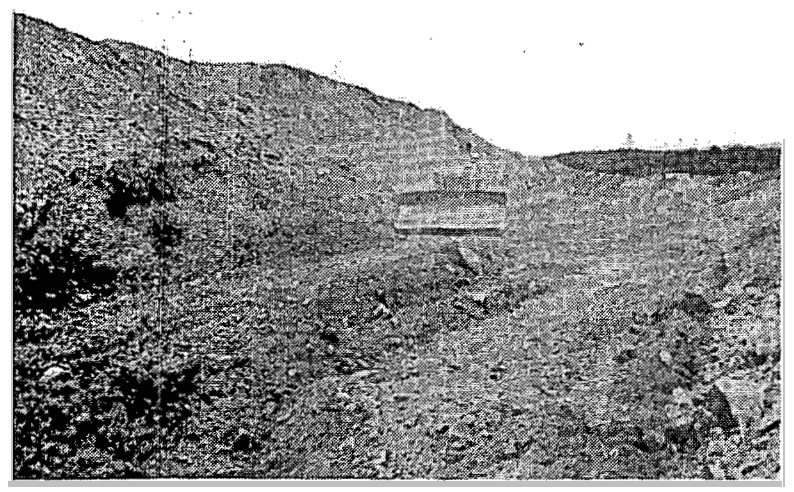

Fig. 30. Dozer daylighting end of cut and bringing cut to grade.

material was pushed into the crater and the operation progressed towards the west end of the crater, cutting and filling as required. A considerable mound of material was pushed out the west end of the crater. This operation is shown in Fig. 30. Some ripping was necessary in order to daylight the ends of the crater; daylighting of the ends was not included in the experiment design.

Three working days were required to daylight the ends and bring the bottom of the crater to rough subgrade. Two additional days were spent in scaling the slopes and final leveling of the bottom of the cut. A $5-\mathrm{yd}^{3}$ front-loader was brought in to 
assist the dozer in scaling the slopes because of the difficulty in negotiating the slopes with a blade full of material. The slopes were scaled by pushing the material into the crater and spoiling it with the front loader, as shown in Fig. 31.

The area in the vicinity of Station $91+60$ was somewhat troublesome because of the steepness of the crater slopes, large particle sizes, and the amount of rubble in the bottom of the crater. Several hundred cubic yards of material were removed from this area alone. Figure 32 shows the final cut configuration.

Total equipment time required was 45 dozer-hours and 16 front-loader hours. Equipment time could have been reduced substantially had the crater been daylighted by the explosion, in which case it is estimated that the cut could have been shaped in about 3 working days.

\section{FALLBACK COMPACTION AND FIELD SETTLEMENT STUDY}

Surveys were made to record any fallback settlement that might occur naturally, or might be induced by a heavy vibratory compactor. Six surface settlement

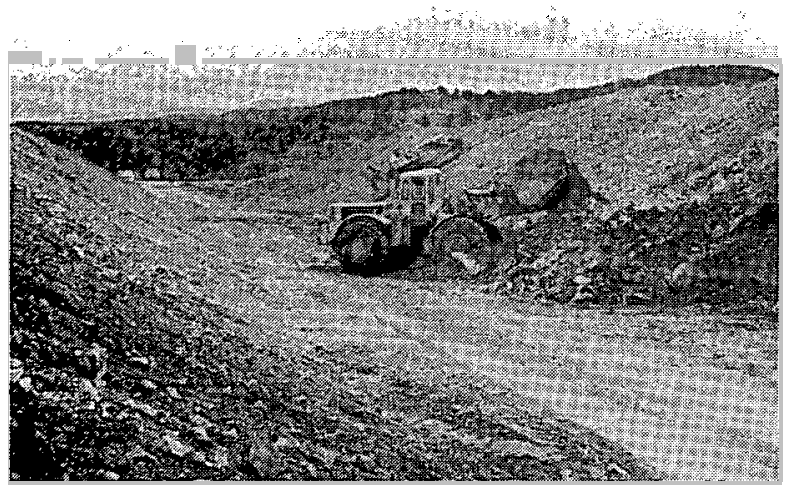

Fig. 31. Dozer scales crater slopes; front loader removes material from crater. markers, detailed in Fig. 33, were emplaced in the undisturbed fallback. The markers were emplaced on the natural mounds and valleys of the crater bottom in order to observe settlements of different thicknesses of fallback. The locations of the markers are shown in Fig. 34.

These markers were first surveyed on 18 December 1970, and surveyed again 4 mo later on 17 April 1971. During the

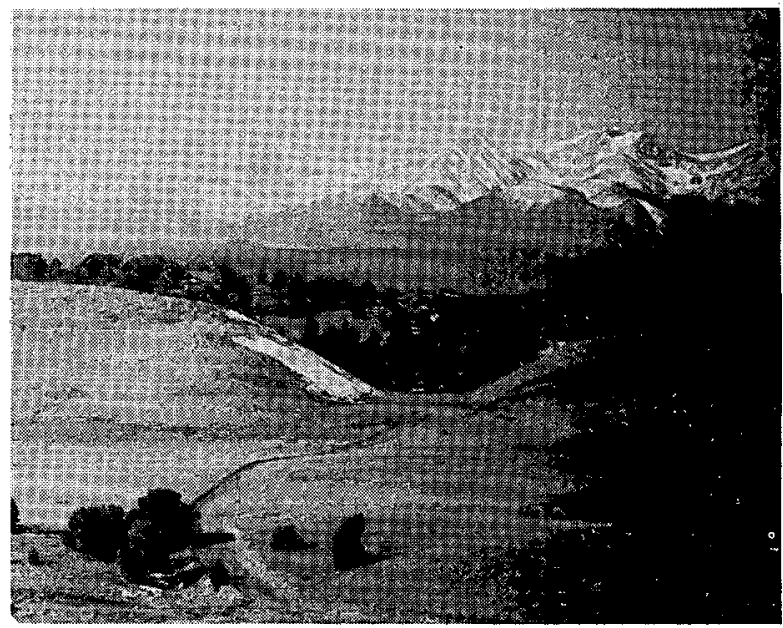

Fig. 32. Finished cut.

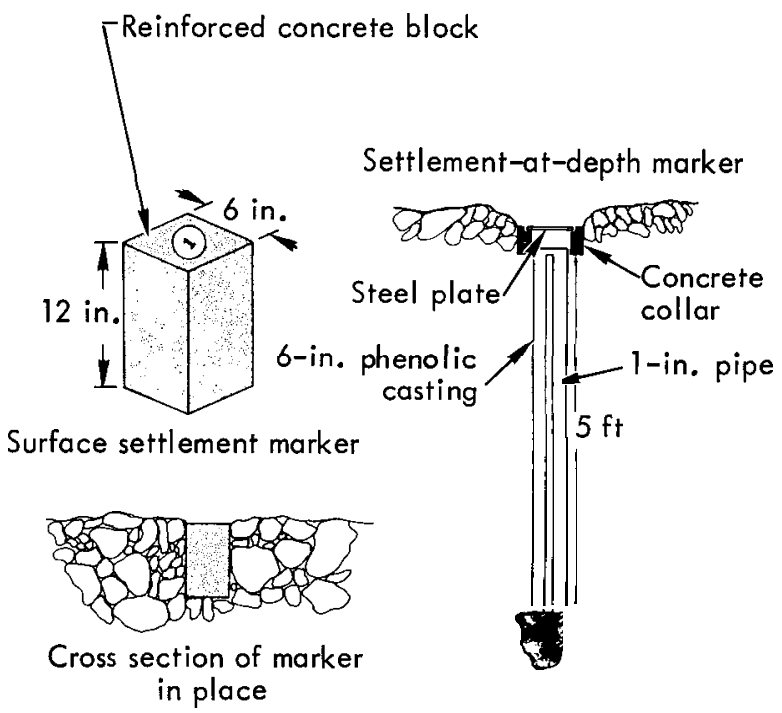

Fig. 33. Settlement markers. 


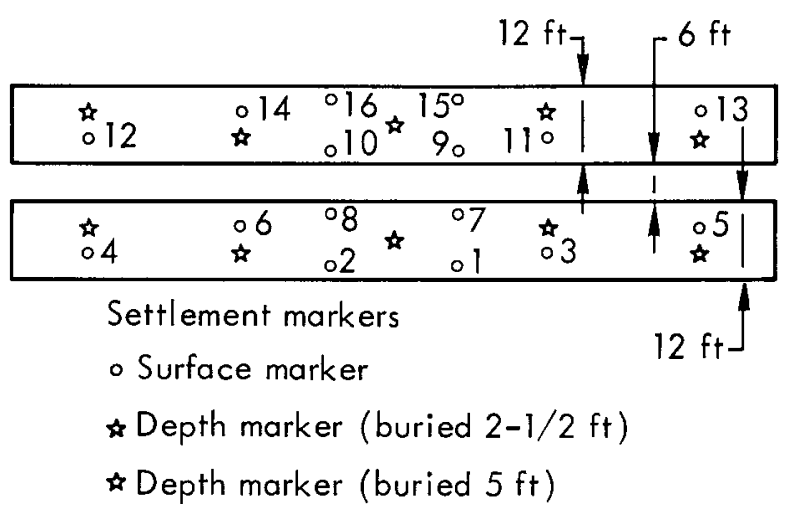

Fig. 34. Layout of settlement markers for vibratory compaction tests.

intervening 4 mo the material was subjected to 14 in. of precipitation; however, comparison of the levels showed negligible settlement during this period.

Vibratory compaction of the dressed cut started after two test panels had been laid out along the centerline, as shown in Fig. 34. Surface markers were placed in hand-excavated holes, and the displaced material was carefully replaced.

Settlement-at-depth markers were emplaced in 6 -in. diameter drilled holes lined with a plastic casing. A rock bit and air, rather than drilling mud or water, were used to drill these holes to minimize disturbance of the fallback. It was recognized that the vibrations from the drill bit would probably cause some unavoidable settlement in the surrounding medium. A 1 -in. diameter pipe was embedded in a small quantity of grout at the bottom of the holes, and a concrete collar and steel plate were then placed over the hole. Markers were placed at 2.5 and $5-\mathrm{ft}$ depths. The tops of all markers were surveyed both vertically and horizontally to $0.001 \mathrm{ft}$.

A smooth-roller vibratory compactor, illustrated in Fig. 35, made 40 passes

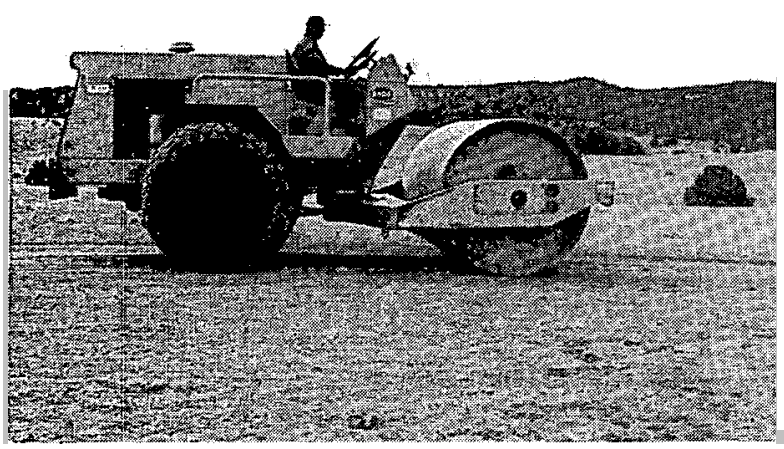

Fig. 35. Bros smooth-roller vibratory compactor.

over each test panel. Specifications for the BROS Model SPV-730 are as follows:

Total weight, lb 20,000

Dynamic force, $l b$ 30,000

Vibration frequency, vpm $1,100-1,500$ Drum width, in. 84

Travel speed, mph

0 to 12

Total applied force, $1 \mathrm{~b}$ 42,200

The settlement markers were surveyed for vertical displacement after 2, 5, 10 , 20 , and 40 passes, and for horizontal displacement after the final pass. The observed settlement of the surface is plotted against the number of passes in Fig. 36 together with representative curves of the average and the maximum settlements.

No settlement at depth was observed. Any apparent movements were well within the limits of surveying error. The lack of measurable settlement at depth probably reflects the combined effects of particle gradation, the compaction of the material falling under impact after the explosion, compaction due to the construction equipment shaping the cut, and the inability of a large vibratory compacter 


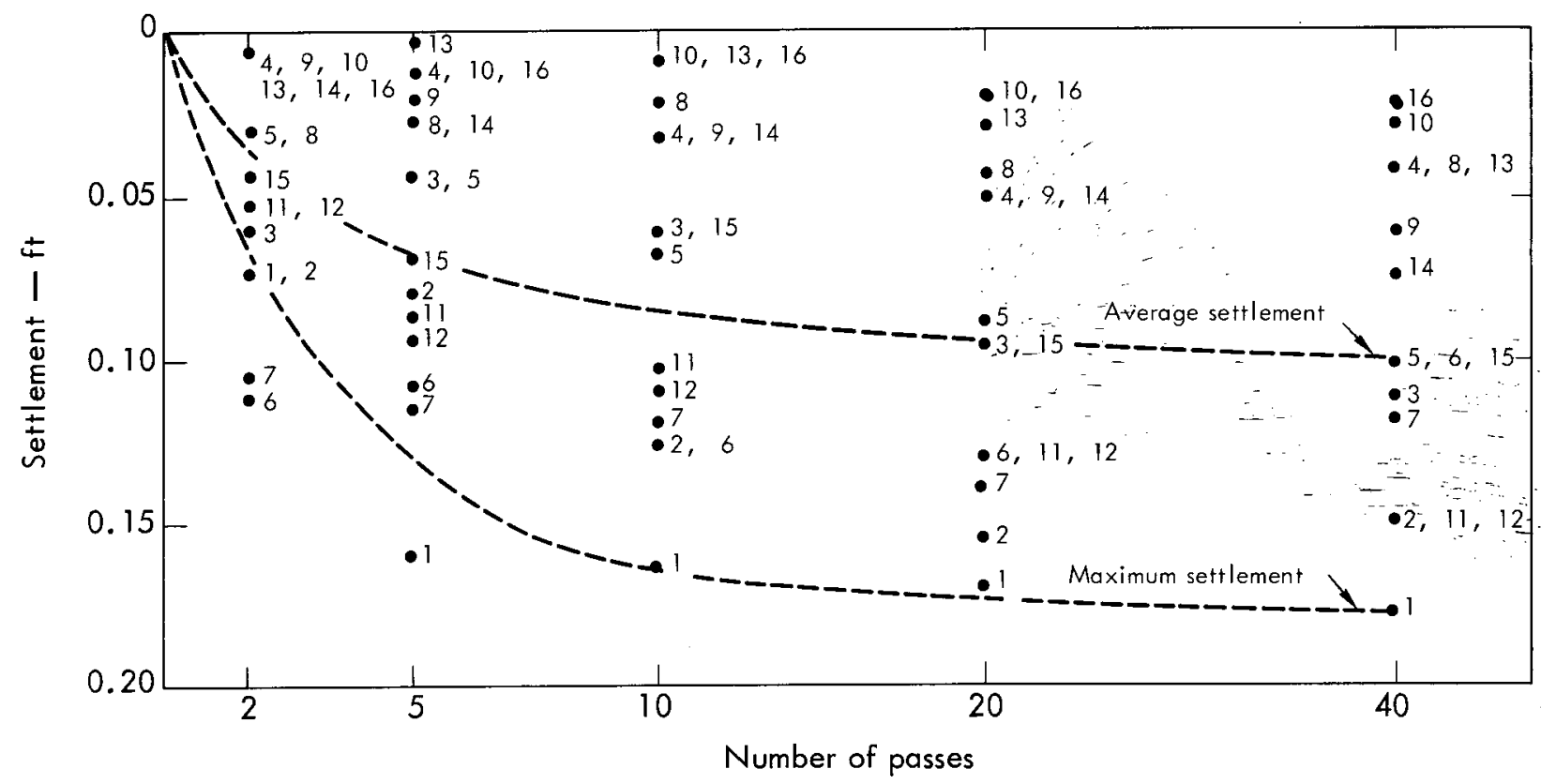

Fig. 36. Surface settlement produced by vibratory compaction tests .

to appreciably affect the material at 2.5and 5-ft depths.

The compaction portion of the field testing originally included a test in which the material was wetted before compaction. It was anticipated that this wetting of the fallback would wash the fines from between the larger particles, and weaken the larger particles, resulting in settle- ment similar to that observed in rock-fill dams. However, the high percentage of fines and their clay nature negated this portion of the testing. The water did not percolate down through the material, but merely puddled at the surface. The results of the laboratory tests reported in Appendix $\mathrm{E}$ provide further insight into the wet behavior of this material.

\section{Chapter 7. Conclusions}

The single charges detonated in the B-series showed that the optimum depth of burial for 1 ton of metallized slurry (TD-2), or for 1 ton of ANFO, is approximately $18 \mathrm{ft}$. This series also indicated that the TD-2 slurry is about $50 \%$ more effective than AFNO as a cratering explosive. The relative inferiority of ANFO, however, was not substantiated by the D1 experiment in which the ANFO nearly equalled TD-2 in cratering performance. The reason for the discrepancy between the single- and row-charge results is not clear.

The concept of enhancement, which was originally developed in a weakclay shale and which forms the bas is for row-charge design, was confirmed for the Trinidad sandstones and shales and can be extended to other rock types with confidence. 
The use of millisecond time delays between the charges in a row offers a promising method of reducing ground shock and airblast without incurring an unacceptable loss of row-charge cratering efficiency. In general, the seismic and airblast amplitudes generated by a delayed row-charge were approximately equivalent to what would be generated by one of the charges in the row detonated by itself. Although the two delay times of 25 and $50 \mathrm{msec}$ resulted in about equal reductions of airblast and groundshock, the shorter delay is definitely preferred because it has the least effect on crater volume. It is tentatively concluded that a delay of $25 \mathrm{msec} / \operatorname{ton}^{1 / 3}$ is appropriate for delayed row-charges.

Comparison of the simultaneously detonated double row, $\mathrm{C} 6$, and the D4 delayed double row demonstrates that the introduction of a delay time between the detonation of parallel row charges increases cratering performance of a double row. The delay time should be of the same order as the vent time," which is approximately $150 \mathrm{msec} /$ ton $^{1 / 3}$ for charges buried at optimum cratering depth.

The single and double rows along a sidehill produced relatively broad, shallow craters. The charge spacing was too wide in the D2 single row, and the performance of the explosive and the time delay between rows were questionable in the D3 double row. It is now believed that the charges in D3 were buried too deeply and too far apart, the consequence of using an incorrect value of explosive bubble energy to design the experiment.

The time at which the explosion gases urider the rising mound of rock are vented to the atmosphere.
The final experiment, the D4 railway cut, is considered a success in all respects. A subsequent analysis of the direct costs of emplacement drilling, explosives and postshot shaping indicates that the cut was explosively excavated for approximately $\$ 36,000$. The Government estimate of the cost to accomplish the same amount of work by conventional methods, including presplitting for slope control, was approximately $\$ 47,000$.

The results of the seismic and airblast programs are important contributions to the technology. Measurement of the effects of the single- and multiple-charge detonations makes it much easier to predict these side effects for future detonations.

A number of specific conclusions can be made with regard to the engineering properties of the craters, an important aspect of explosive excavation: These conclusions are based on investigations of the D4 crater.

Cratering detonations in the heterogeneous weak-to-intermediate-strength rock at Trinidad produce rubble with a particle gradation that can be classified as a poorly graded gravel in the Unified Soil Classification System, and can also be described as a clayey gravel. The material is fragmented to the extent that necessary earthwork can be accomplished quickly and easily, with a minimum of equipment.

The D4 delayed row-charge detonation ejected enough material from the crater that the thickness of fallback material susceptible to settlement was reduced significantly. Moreover, there is considerable evidence that the fallback is favorably compacted by the impact of its 
deposition. The value of relative density of $70 \%$ estimated for the Trinidad fallback in the field is almost as great as the relative densities achieved in many engineered fills (see Appendix E). It is not expected that the fallback will be susceptible to large settlements or stability problems.

The rocks of which the fallback is composed are weakened by water, and, as a result, saturation of the material would cause settlement and would reduce the angle of internal friction by several degrees. The cohesion of the rubble, the intact horizontal bedding surrounding the cut, the wet and dry angle of internal friction, and the gentle 30 -deg side slopes provide adequate assurance of continued slope stability.

The smaller particles of the fallback are softer and more highly susceptible to compression when wetted. Consequently, the amount of settlement due to wetting cannot be estimated on the basis of tests on small size specimens of "mode1" materials. The test results in
Appendix E do show, however, that it is possible to determine the angle of internal friction by testing model materials with grain-size curves parallel to the actual grain-size curve, provided that the specimens were compacted to the relative density of the actual fallback. The inability to estimate settlement from the behavior of the modeled material at Trinidad is valuable documentation of the media dependency of modeling materials. Higher strength and more homogeneous materials investigated by Marachi et al. ${ }^{20}$ show much better modeling characteristics.

The rock surrounding the cut was disturbed only in the immediate vicinity, with little evidence of an extensive rupture zone. The weak, fractured, and weathered nature of the rock probably accounts for the limited extent of the rupture zone.

Finally, the point-count technique provided a reasonably accurate particle gradation curve (see Appendix E). More experience is needed in dealing with fines and their relationship to the coarse fraction of the material. 


\section{Appendix A}

\section{Drill Hole Locations, Stratigraphy and Lithology, and Material Properties Data}

This appendix contains detailed information about the experimental sites. Figures $A 1$ and $A 2$ are topographic maps showing the location of all charges in each experiment. The stratigraphic sections for each series, obtained from the core holes, are shown in Figs. A3 through $A 6$, and the laboratory-determined physical properties of the rock are given in Table A1.

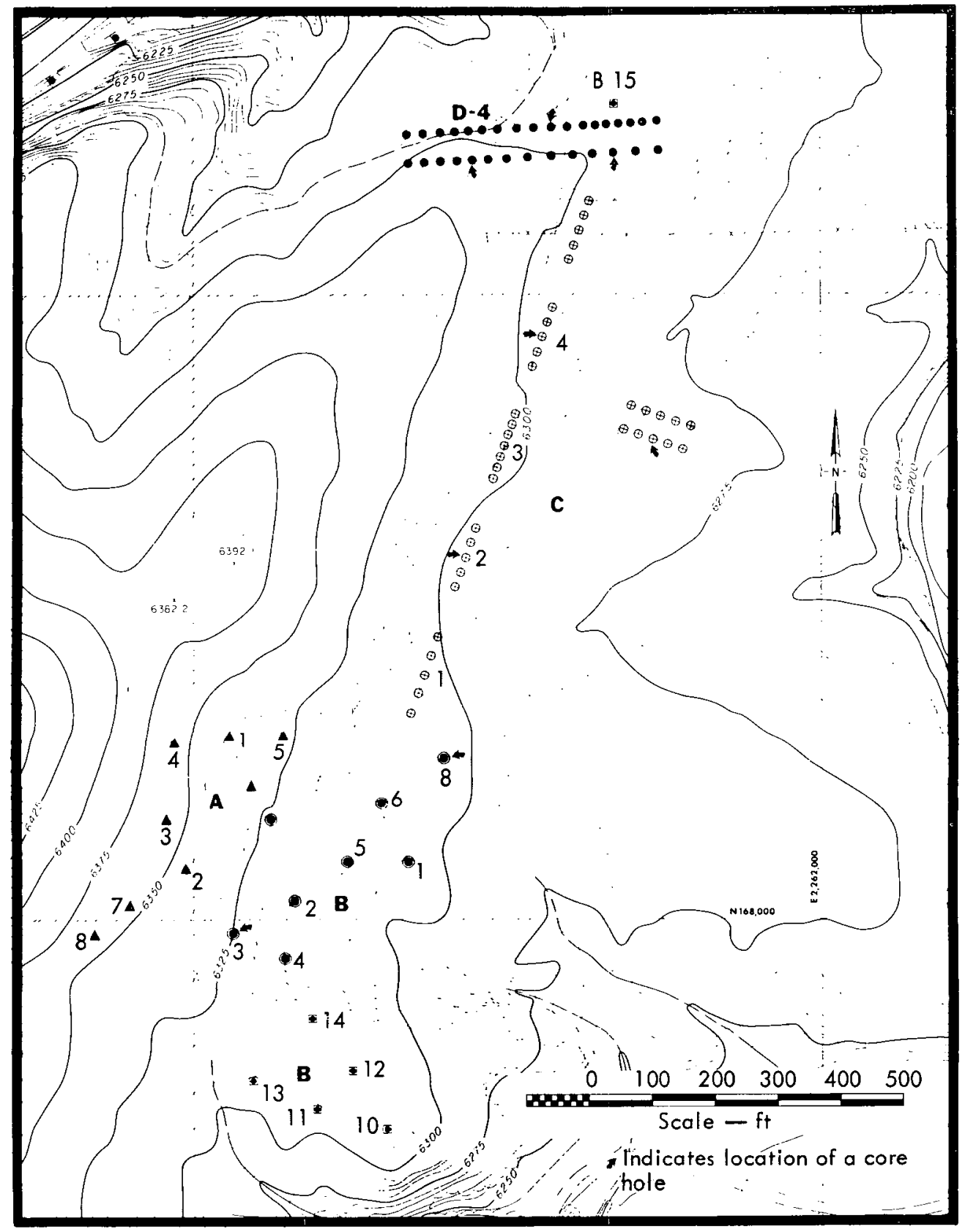

Fig. A1. Map showing location of core holes for B and C series and D4 railroad cut. 


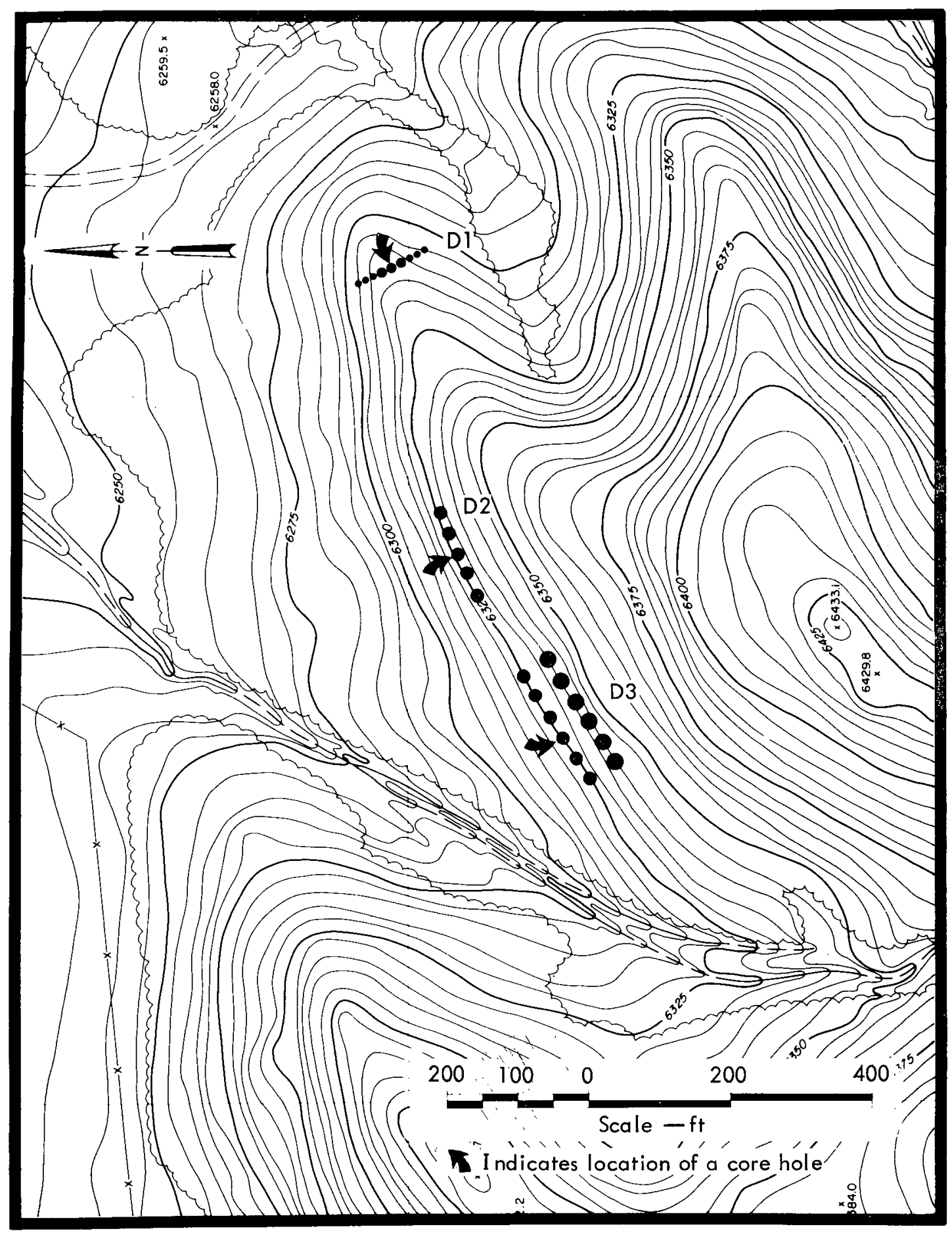

Fig. A2. Map showing location of emplacement and core holes for Experiments $\mathrm{D} 1, \mathrm{D} 2$, and D3. 


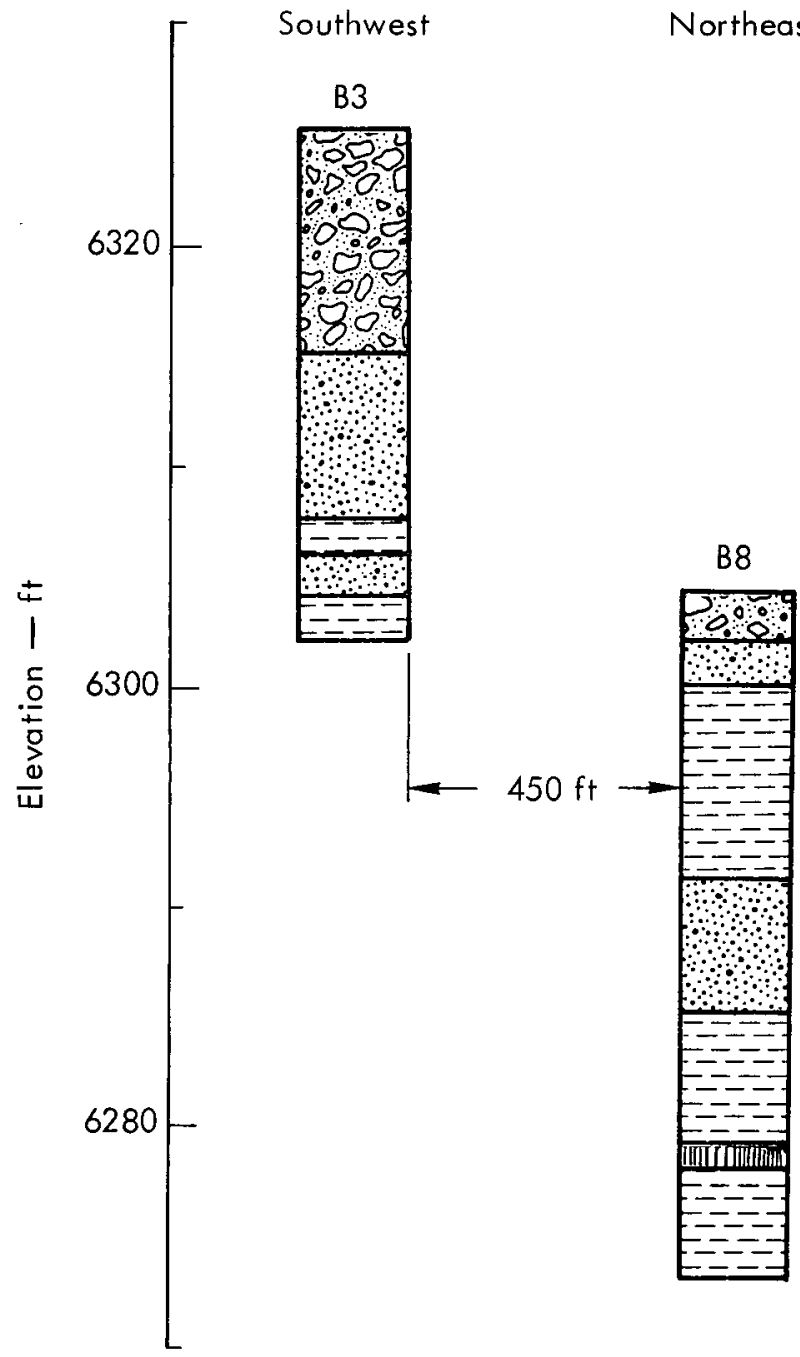

$\underline{\text { Legend }}$

ORERBURDEN: Clayey soil with platy fragments of sandstone and river-run cobbles.

SANDSTONE: Fine to medium-grained arkosic sandstone, moderate to highly fractured.

E- SHALE: Grey to black silty shale, highly fractured.

COAL: Soft bituminous coal, very highly fractured.

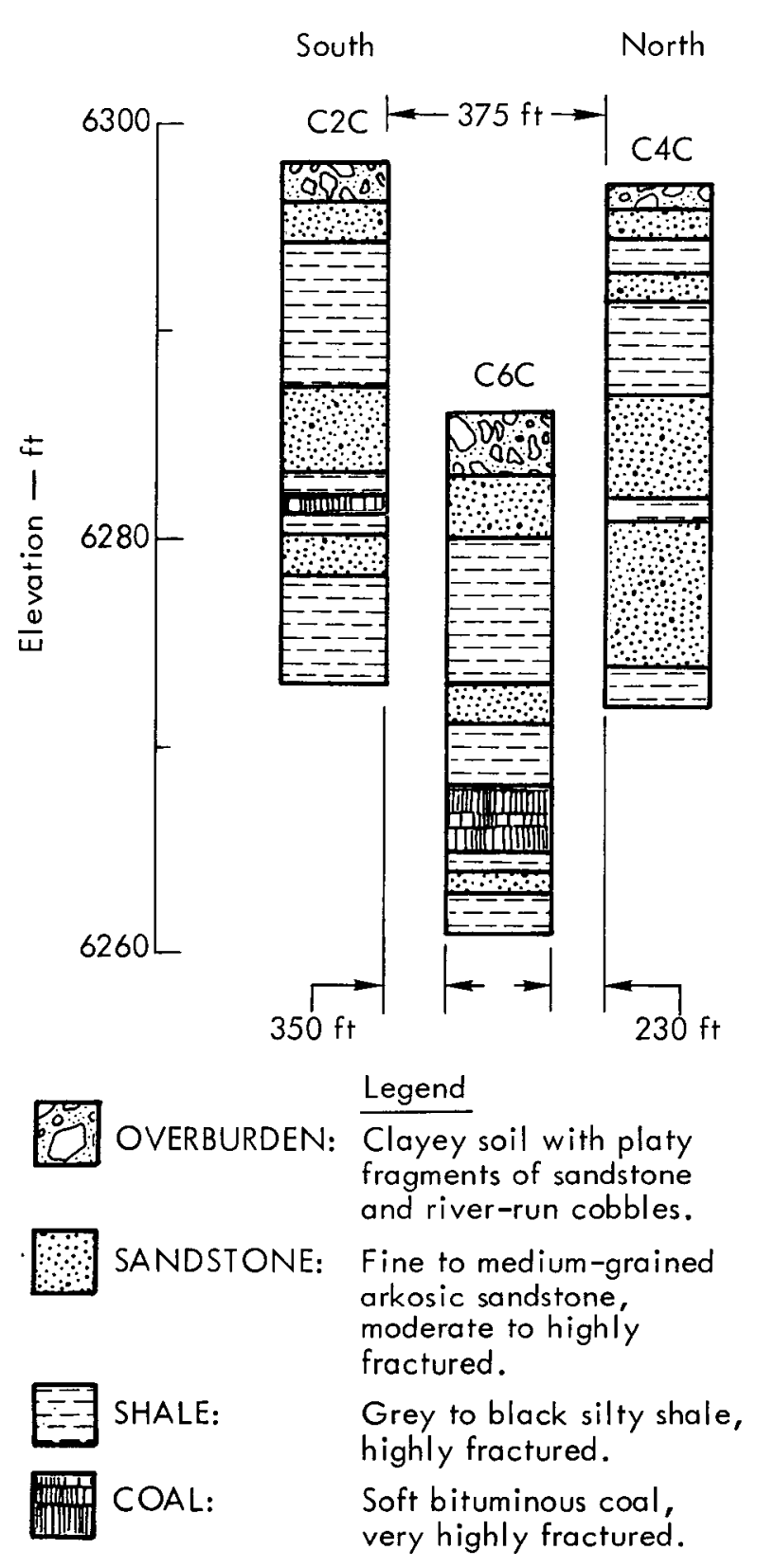

Fig. A4. Stratigraphy and lithology of C series. 


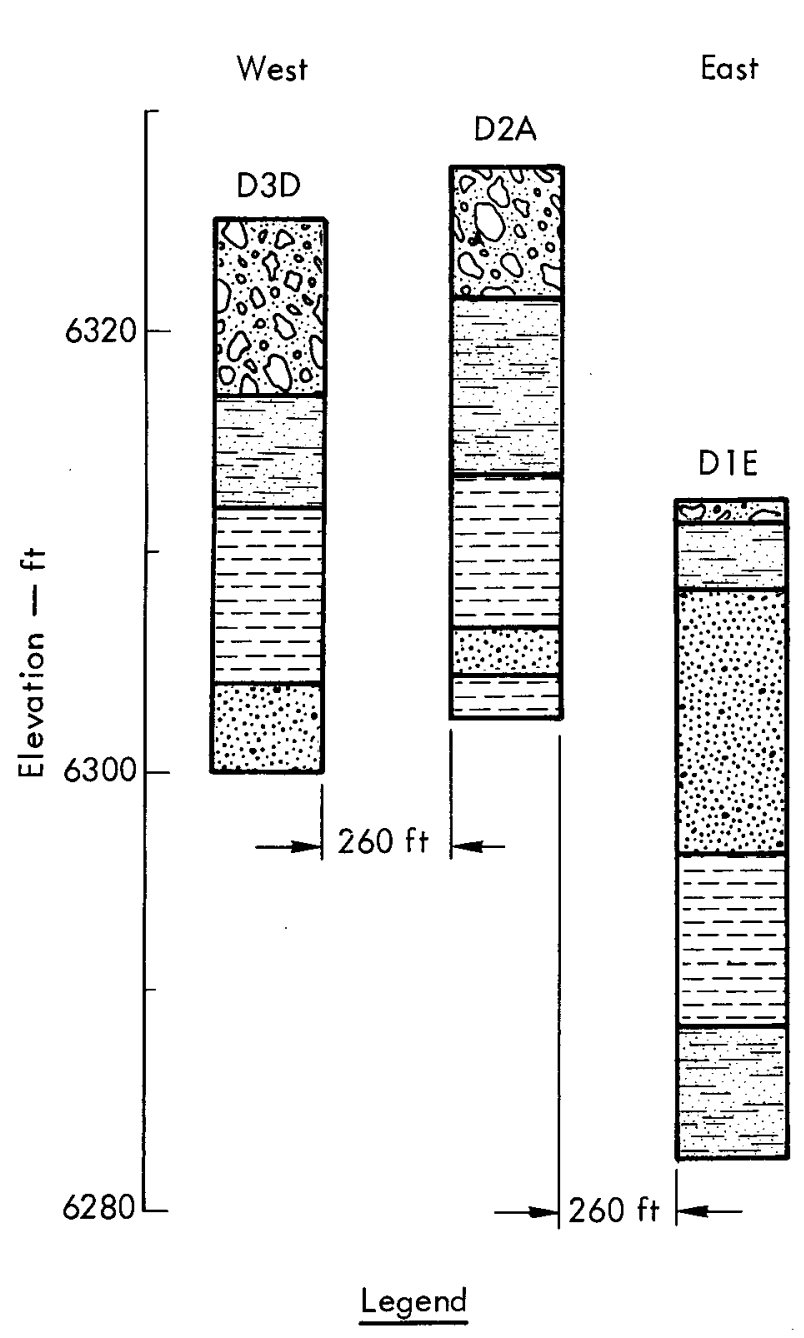

0.0 OVERBURDEN: Clayey soil with platy fragments of sandstone and river-run cobbles.

2 SANDSTONE: Fine to medium-grained arkosic sandstone, moderate to highly fractured.

SILTSTONE: Grey-green siltstone, highly fractured.

SHALE: Grey to black silty shale, highly fractured.

Fig. A5. Stratigraphy and lithology of Experiments D1, D2, and D3.

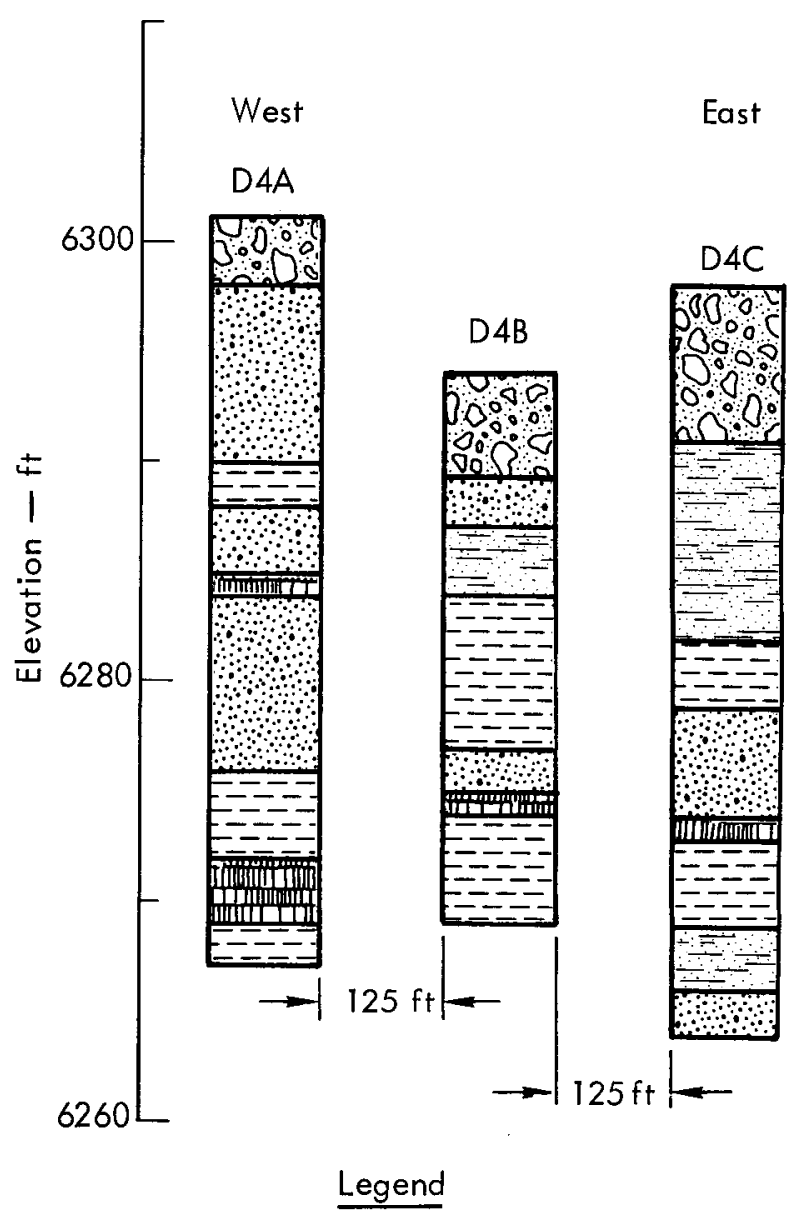

OVERBURDEN: Clayey soil with platy fragments of sandstone and river run cobbles.

SANDSTONE: Fine to medium-grained arkosic sandstone, moderate to highly fractured.

SILTSTONE: Grey-green siltstone, highly fractured.

SHALE: Grey to black silty shale, highly fractured.

COAL: Soft bituminous coal, very highly fractured.

Fig. A6. Stratigraphy and lithology of D4 railroad cut. 
Table A1. Results of tests of B-series rock cores.

\begin{tabular}{|c|c|c|c|c|c|c|c|c|}
\hline $\begin{array}{l}\text { Hole } \\
\text { number }\end{array}$ & $\begin{array}{l}\text { Depth } \\
\text { (ft) }\end{array}$ & $\begin{array}{c}\text { Water } \\
\text { content } \\
(\%)\end{array}$ & $\begin{array}{l}\text { Dry } \\
\text { density } \\
\left(\mathrm{lb} / \mathrm{ft}^{3}\right)\end{array}$ & $\begin{array}{l}\text { Crain } \\
\text { specific } \\
\text { gravity }\end{array}$ & $\begin{array}{l}\text { Porosity } \\
(\%)\end{array}$ & $\begin{array}{l}\text { Compressive } \\
\text { strength } \\
\text { (psi) }\end{array}$ & $\begin{array}{l}\text { Modulus } \\
\text { of elasticity } \\
\left(10^{6} \mathrm{psi}\right)\end{array}$ & Description and rumarks \\
\hline 133 & $19.1-19.8$ & 3.0 & 150.1 & 2.70 & 10.7 & 4563 & $0.4-1.3$ & $\begin{array}{l}\text { l.ight gray sandstone with hairline to } \\
1 / 16 \mathrm{im} \text {. shale seams. }\end{array}$ \\
\hline 133 & $19.8-20.8$ & 3.8 & 151.3 & 2.70 & 10.4 & $5937^{\mathrm{b}}$ & 1.3 & L-ight gray sandstone, fine grained. \\
\hline 83 & $21.0-22.0$ & 3.2 & 156.5 & 2.70 & 7.1 & 1739 & 0.23 & $\begin{array}{l}\text { Dark gray silty sandstone, very fined } \\
\text { grained. }\end{array}$ \\
\hline 138 & $13.2-13.5$ & 5.1 & 149.2 & 2.70 & 11.5 & $1833^{\mathrm{b}, \mathrm{c}}$ & $0.80^{\mathrm{C}}$ & $\begin{array}{l}\text { Tan siltstone with random orientated } \\
\text { shale stringers. Free water was } \\
\text { observed on the surface of the test } \\
\text { specimen while under compression. }\end{array}$ \\
\hline B8 & $15.8-17.0$ & 2.7 & 156.7 & 2.71 & 7.4 & 5150 & 1.5 & J.ight gray sandstone, fine grained. \\
\hline B8 & $21.5-22.2$ & 4.4 & 146.0 & 2.70 & 13.3 & $1027^{b}$ & 0.072 & $\begin{array}{l}\text { Gray sandy siltstone with shale seams } \\
\text { to } 1 \text { in. wide. Free water was } \\
\text { olsserved on the surface of the test } \\
\text { specimen while under compression. }\end{array}$ \\
\hline B8 & $24.8-27.2$ & 2.0 & 106.1 & 1.82 & 6.6 & $1070^{\mathrm{b}}$ & 0.23 & Coal. \\
\hline $\mathrm{B} 8$ & $27.0-28.4$ & 1.2 & 160.8 & 2.72 & 5.3 & 493 & 0.33 & $\begin{array}{l}\text { Gray sandy siltstone with irregular } \\
\text { shale and coal seams hairline to } \\
2 \text { in. wide, and party open fractures. } \\
\text { Failure occurred along a high angle, } \\
\text { partly open fracture. }\end{array}$ \\
\hline
\end{tabular}

Water content was determined on fragments remaining from compression test.

${ }^{\mathrm{b}}$ Values for unconfined compressive strength have been adjusted for height-diameter ratio per ASTN C-42.

${ }^{c}$ Liameter of test specimen was not uniform due to drilling action. 
Table A2. Results of tests of C-series rock cores.

\begin{tabular}{|c|c|c|c|c|c|c|c|c|c|}
\hline $\begin{array}{l}\text { Hole } \\
\text { number }\end{array}$ & $\begin{array}{r}\text { Dep } \\
\text { (ft }\end{array}$ & & $\begin{array}{l}\text { Water } \\
\text { content } \\
(\%)\end{array}$ & $\begin{array}{l}\text { Dry } \\
\text { density } \\
\left(1 \mathrm{~b} / \mathrm{ft}^{3}\right)\end{array}$ & $\begin{array}{l}\text { Grain } \\
\text { specific } \\
\text { gravity }\end{array}$ & $\begin{array}{l}\text { Porosity } \\
(\%)\end{array}$ & $\begin{array}{l}\text { Compressive } \\
\text { strengtha } \\
\text { (psi) }\end{array}$ & $\begin{array}{l}\text { Modulus } \\
\text { of elasticity } \\
\left(10^{6} \mathrm{psi}\right)\end{array}$ & Description and remarks \\
\hline $\mathrm{C} 2 \mathrm{C}$ & 2.5 & -3.0 & 2.6 & 150.2 & 2.68 & 10.2 & - & - & $\begin{array}{l}\text { Sandstone, tan, fractured, thin layer of } \\
\text { brown clay along factures. }\end{array}$ \\
\hline $\mathrm{C} 2 \mathrm{C}$ & 10.9 & -12.1 & 2.1 & 159.5 & 2.66 & 4.0 & 6420 & 3.2 & $\begin{array}{l}\text { Sandstone, tan, horizontal fractures at } \\
11.5 \mathrm{ft} .\end{array}$ \\
\hline $\mathrm{C} 2 \mathrm{C}$ & 12.1 & -12.9 & 2.6 & 160.4 & 2.74 & 6.2 & 1370 & 0.38 & $\begin{array}{l}\text { Sandstone, fine-grained, gray, partly } \\
\text { open fractures. }\end{array}$ \\
\hline $\mathrm{C} 2 \mathrm{C}$ & 13.1 & -15.0 & 2.9 & 152.9 & 2.69 & 8.9 & 7260 & $0.5-1.3$ & $\begin{array}{l}\text { Siltstone, gray, numerous hairline to } \\
1 / 8 \text { in. shale seams from } 13.1-13.8 \mathrm{ft} \text {. }\end{array}$ \\
\hline $\mathrm{C} 2 \mathrm{C}$ & 17.25 & $5-18.2$ & 4.3 & 138.1 & 2.46 & 10.1 & 1290 & 0.14 & $\begin{array}{l}\text { Top } 6 \text { in. transition zone from coal to } \\
\text { gray siltstone separated at } 18.1 \text { and } \\
19.35 \mathrm{ft} 1 \mathrm{in} \text {. shale band at } 18.9- \\
19.0 \mathrm{ft} \text {, partly open vertical fracture } \\
\text { from } 19.0-19.3 \mathrm{ft} \text {, partly open } \\
\text { fractures from } 19.6-19.9 \mathrm{ft} \text {, carbon- } \\
\text { aceous stringers from } 18.1-18.5 \mathrm{ft} .\end{array}$ \\
\hline $\mathrm{C} 2 \mathrm{C}$ & 18.2 & -19.9 & 4.2 & 150.8 & 2.69 & 10.2 & 1290 & 0.13 & $\begin{array}{l}\text { Dark gray, highly carbonaceous siltstone, } \\
\text { healed vertical fracture from } 21.7- \\
22.5 \mathrm{ft} \text {. }\end{array}$ \\
\hline $\mathrm{C} 2 \mathrm{C}$ & 21.7 & -22.78 & 2.8 & 156.3 & 2.71 & 7.6 & 3260 & 0.75 & $\begin{array}{l}\text { Dark gray, highly carbonaceous siltstone, } \\
\text { healed vertical fracture from } 21.7- \\
22.5 \mathrm{ft} .\end{array}$ \\
\hline $\mathrm{C} 4 \mathrm{C}$ & 10.34 & $4-10.98$ & 2.8 & 153.6 & 2.67 & 7.9 & 6380 & 1.6 & $\begin{array}{l}\text { Sandstone, tan, with irregular shale seams } \\
\text { hairline to } 1 / 16 \text { in. }\end{array}$ \\
\hline $\mathrm{C} 4 \mathrm{C}$ & 21.0 & -22.7 & 2.8 & 150.9 & 2.69 & 10.1 & 7340 & $0.7-1.2$ & $\begin{array}{l}\text { Transition from tan sandstone to gray sand- } \\
\text { stone, high angle fracture from } 21.0- \\
21.8 \mathrm{ft} \text {. }\end{array}$ \\
\hline $\mathrm{C} 6 \mathrm{C}$ & 20.0 & -20.72 & 9.2 & 78.1 & 1.50 & 16.6 & - & - & Coal, fractured. \\
\hline $\mathrm{C} 6 \mathrm{C}$ & 21.2 & -22.44 & 2.1 & 157.0 & 2.72 & 7.5 & 6350 & $1.0-1.5$ & $\begin{array}{l}\text { Transition from tan sandstone to gray sand- } \\
\text { stone with irregular shale seams up to } \\
1 \text { in. Partially opened horizontal fracture } \\
\text { at } 22.0 \mathrm{ft} \text {. }\end{array}$ \\
\hline
\end{tabular}

\footnotetext{
${ }^{\mathrm{a}}$ Values for unconfined compressive strength have been adjusted for height-diameter ratio per ASTM C-42.
} 
Table A3. Results of tests of D-series rock cores.

\begin{tabular}{|c|c|c|c|c|c|c|c|c|}
\hline $\begin{array}{l}\text { Hole } \\
\text { number }\end{array}$ & $\begin{array}{l}\text { Depth } \\
\text { (ft) }\end{array}$ & $\begin{array}{l}\text { Water } \\
\text { content } \\
(\%)\end{array}$ & $\begin{array}{l}\text { Dry } \\
\text { density } \\
\left(1 \mathrm{~b} / \mathrm{ft}^{3}\right)\end{array}$ & $\begin{array}{l}\text { Grain } \\
\text { specific } \\
\text { gravity }\end{array}$ & $\begin{array}{l}\text { Porosity } \\
(\%)\end{array}$ & $\begin{array}{l}\text { Compressive } \\
\text { strength } \\
\text { (psi) }\end{array}$ & $\begin{array}{l}\text { Modulus } \\
\text { of elasticity } \\
\left(10^{6} \text { psi) }\right.\end{array}$ & Description and remarks \\
\hline \multirow[t]{6}{*}{ D1E } & $3.8-5.1$ & 4.1 & 144.6 & 2,69 & 14 & 3608 & 0.65 & $\begin{array}{l}\text { Sandstone, light brown, intersecting high } \\
\text { angle fractures from } 3.8-4.5 \mathrm{ft} \text {. }\end{array}$ \\
\hline & $5.6-6.5$ & 4.1 & 149.4 & 2.66 & 10 & 2947 & 0.41 & Sandstone, light brown, hard. \\
\hline & $9.7-11.3$ & 5.9 & 138.9 & 2.69 & 17 & 883 & 0.12 & $\begin{array}{l}\text { Sandstone, light brown, } 60 \text { deg fracture } \\
\text { from } 9,7-10.1 \mathrm{ft} ; 45 \mathrm{deg} \text { incipient } \\
\text { fracture } 10.3-10.7 \mathrm{ft} \text {. }\end{array}$ \\
\hline & $12.1-13.7$ & 2.8 & 150.5 & 2.69 & 11 & 2163 & 0.31 & $\begin{array}{l}\text { Sandstone, light gray, changing to light } \\
\text { brown at } 12.8 \mathrm{ft} \text {; numerous incipient } \\
\text { fractures. }\end{array}$ \\
\hline & $21.4-22.0$ & 7.3 & 138.7 & 2.71 & 18 & 460 & 0.13 & Shale, light gray, hard. \\
\hline & $28.6-29.6$ & 4.9 & 145.4 & 2.73 & 14 & 873 & 0.25 & $\begin{array}{l}\text { Shale, light gray, hard, approximate } \\
45 \mathrm{deg} \text { incipient fracture top to bottom. }\end{array}$ \\
\hline \multirow[t]{4}{*}{ D3I } & $11.9-12.8$ & 2.1 & 155.1 & 2.70 & 8 & 8272 & 2.35 & $\begin{array}{l}\text { Sandstone, very light brown, very fine- } \\
\text { grained, hard. Very thin layers of } \\
\text { shale at both ends of sample. }\end{array}$ \\
\hline & $13.0-14.3$ & 3.5 & 148.4 & 2.65 & 10 & 530 & 0.24 & Siltstone, light gray, much-fractured. \\
\hline & $18.7-19.5$ & 3.0 & 152.7 & 2.62 & 7 & 1373 & 0.67 & $\begin{array}{l}\text { Siltstone, shaly, light gray, horizontal } \\
\text { separation planes at } 18.9 \text { and } 19.1 \mathrm{ft} \text {. }\end{array}$ \\
\hline & $21.5-22.5$ & 4.6 & 148.9 & 2.66 & 11 & 1074 & 0.25 & $\begin{array}{l}\text { Siltstone, shaly, light gray, hard. } \\
\text { Horizontal slickensided fracture at } \\
22.0 \mathrm{ft} \text {. }\end{array}$ \\
\hline \multirow[t]{8}{*}{$\mathrm{D} 4 \mathrm{~A}$} & $12.0-12.6$ & 3.3 & 151.9 & 2.63 & 7 & 3055 & 0.50 & $\begin{array}{l}\text { Sandstone, light gray, fine-grained: } \\
\text { numerous horizontal separation planes. }\end{array}$ \\
\hline & $15.5-16.6$ & 5.0 & 138.9 & 2.66 & 16 & 3853 & 0.74 & Sandstone, light brown, hard. \\
\hline & $21.2-22.0$ & 3.8 & 151.3 & 2.71 & 10 & 2000 & $1: 04$ & $\begin{array}{l}\text { Sandstone, light brown, hard; } 60 \mathrm{deg} \text { frac- } \\
\text { ture for compression test. }\end{array}$ \\
\hline & $22.6-24.0$ & 2.4 & 155.4 & 2.65 & 6 & 6824 & 1.6 & $\begin{array}{l}\text { Sandstone, fine-grained, light gray, hard; } \\
45 \text { deg fracture } 23.1-22.8 \mathrm{ft} \text {. }\end{array}$ \\
\hline & $28.1-28.3$ & 2.7 & 152.2 & 2.69 & 9 & $-^{\mathrm{c}}$ & $-{ }^{c}$ & $\begin{array}{l}\text { Siltstone, light gray, dry, hard; too badly } \\
\text { fractured for compression test. }\end{array}$ \\
\hline & $28.3-28.5$ & 4.4 & 148.0 & 2.71 & 12 & $-^{\mathrm{c}}$ & $-{ }^{c}$ & $\begin{array}{l}\text { Siltstone, shaly, light gray, moist; too } \\
\text { badly fractured for compression test. }\end{array}$ \\
\hline & $32.4-33.1$ & 6.6 & 143.5 & 2.71 & 15 & 510 & 0.09 & $\begin{array}{l}\text { Shale, gray, moist; many thin horizontal } \\
\text { separation planes. }\end{array}$ \\
\hline & $33.1-33.8$ & 4.3 & 149.4 & 2.70 & 12 & 898 & 0.34 & $\begin{array}{l}\text { Shale, light gray, dry, hard; numerous } \\
\text { horizontal separation planes. }\end{array}$ \\
\hline \multirow[t]{3}{*}{ D4 B } & $6.0-0.65$ & 3.6 & 154.3 & 2.66 & 6 & $-^{c}$ & $-{ }^{c}$ & $\begin{array}{l}\text { Siltstone, gray, hard; very badly frac- } \\
\text { tured. }\end{array}$ \\
\hline & $15.3-15.9$ & 3.3 & 150.5 & 2.64 & 9 & 4140 & 2.0 & $\begin{array}{l}\text { Sandstone, light brown, hard; } 1 / 2 \text {-in. shale } \\
\text { seam removed from bottom. }\end{array}$ \\
\hline & $18.85-19.5$ & 7.0 & 140.0 & 2.72 & 17 & 739 & $0.1 !$ & $\begin{array}{l}\text { Shale, gray, moist; numerous slicken- } \\
\text { sided separation planes. }\end{array}$ \\
\hline \multirow[t]{7}{*}{$\mathrm{D} 4 \mathrm{C}$} & $15.9-15.5$ & 2.6 & 152.1 & 2,68 & 9 & 2780 & 0.60 & Sandstone, light brown, fine-grained, hard. \\
\hline & $\begin{array}{l}18.9-19.7 \\
19.7-20.3\end{array}$ & $2^{2.6}$ & ${ }^{151} c^{3}$ & 2.69 & $\frac{10}{-}$ & 4950 & 1.3 & $\begin{array}{l}\text { Sandstone, light brown, hard, } \\
\text { Sandstone, light brown, hard. Very thin } \\
\text { shale seams at } 19.8 \text { and } 19.8 \mathrm{ft} \text {. }\end{array}$ \\
\hline & $22.3-23.9$ & 3.8 & 148.2 & 2.69 & 12 & 4200 & 0.76 & $\begin{array}{l}\text { Sandstone, light brown with light gray band } \\
\text { from } 22.5-23.0 \mathrm{ft} \text {; horizontal separation } \\
\text { planes at } 23.1,23.4 \text {, and } 23.6 \mathrm{ft} \text {. Com- } \\
\text { pression specimen taken from } 23.2- \\
23.8 \mathrm{ft} \text {. }\end{array}$ \\
\hline & $29.2-29.9$ & 3.7 & 150.5 & 2.69 & 11 & 710 & 0.06 & $\begin{array}{l}\text { Siltstone, light gray, hard; fractures at } \\
29.3,29.5 \text {, and } 29.7 \mathrm{ft} \text {. }\end{array}$ \\
\hline & $31.2-31.8$ & 2.1 & 158.7 & 2.69 & 6 & 2460 & 0.56 & $\begin{array}{l}\text { Siltstone, light gray, dry, hard; } 45 \text { deg } \\
\text { separation plane } 31.4-31.7 \mathrm{ft} \text {. }\end{array}$ \\
\hline & $32.0-32.7$ & 1.9 & 154.2 & 2.67 & 7 & 7169 & 0.77 & $\begin{array}{l}\text { Siltstone, light gray, fine }- \text { grained, hard; } \\
\text { numerous thin, shale seams. Horizontal } \\
\text { separation plane at } 32.7 \mathrm{ft} \text {. }\end{array}$ \\
\hline & $32.7-33.5$ & 2.4 & 154.4 & 2.67 & 7 & 4245 & 0.65 & $\begin{array}{l}\text { Sandstone, light gray, fine-grained, hard; } \\
\text { more and thicker layers of shale. }\end{array}$ \\
\hline
\end{tabular}

\footnotetext{
${ }^{a}$ Water content was determined on fragments remaining from compression tests.

${ }^{b}$ Values for unconfined compressive strength have been adjusted for height-diameter ratio per ASTM-C 42.

Not tested.
} 


\section{Appendix B \\ Crater Profiles and Cross Sections}

This appendix contains the cross sections and profiles for all of the B-series and $\mathrm{C}$-series craters. Figure B1 explains the meaning of the terms used in standard crater nomenclature. Each of the singlecharge craters was surveyed along two orthogonal sections, as shown in Figs. B2 through B5. The row craters were crosssectioned at selected, representative locations and were also profiled along the centerline through the charges. The survey data are shown in Figs. B6 through B8. The average widths and depths of the row craters are shown on the drawings.

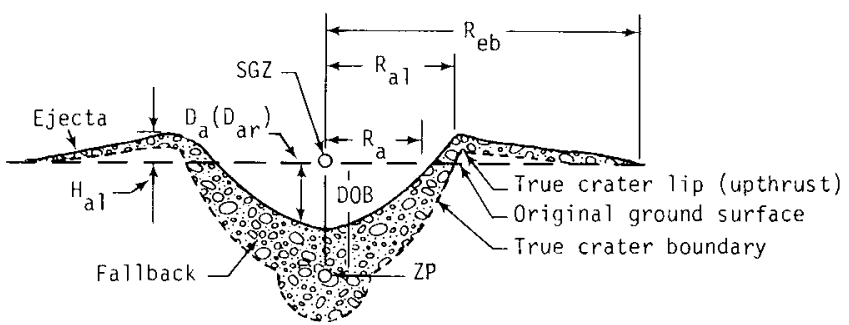

Cross section of sinqle-charge or row crater

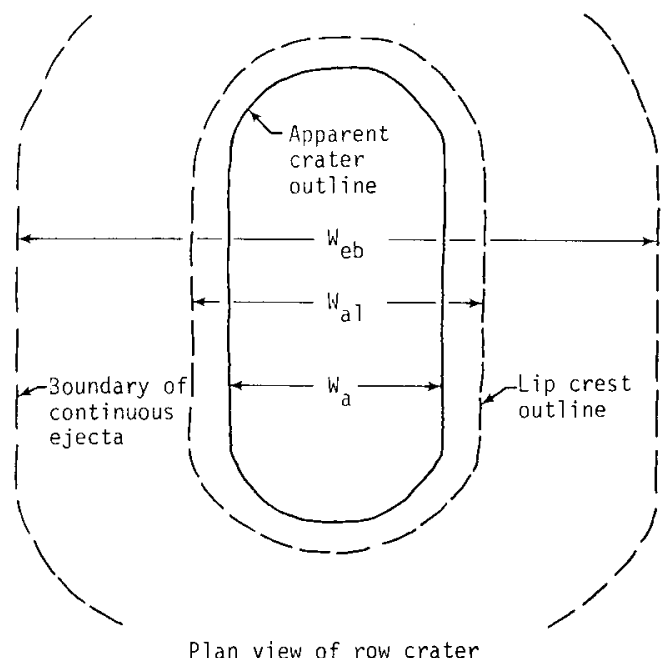

Nomenclature which applies only to singlecharge craters

$R_{a}$ - Radius of apparent crater measured at original ground surface datum

$R_{a l}$ - Radius of apparent lip crest

$R_{e b}$ - Radius of outer boundary of continuous ejecta

$D_{a}$ - Maximum depth of apparent crater below and normal to original ground surface

Nomenclature which applies only to row craters

$W_{a}$ - Width of apparent linear crater measured at original ground surface datum

$w_{a l}$ - Width of apparent lip crest

$W_{\text {eb }}$ - Width of outer boundary of continuous

$D_{a r}$ - Depth of apparent row crater
Nomenclature and definitions which apply to both single-charge and row craters $\mathrm{H}_{\text {al }}$ - Apparent crater lip crest height above $V_{a}$ - Volume of apparent crater below original

$V_{\text {al }}$ - Volume of apparent lip $v_{t}-\begin{aligned} & \text { Volume of true crater below original } \\ & \text { ground surface }\end{aligned}$

$D O B$ - Depth of burst

ZP - Zero Point-effective center of explosion energy

SGZ - Surface Ground Zero (point on surface vertically above $Z \mathrm{P}$ )

NSP - Nearest Surface Point (point on surface nearest ZP; same as SGZ for horizontal surface)

Fig. B1. Crater nomenclature. 


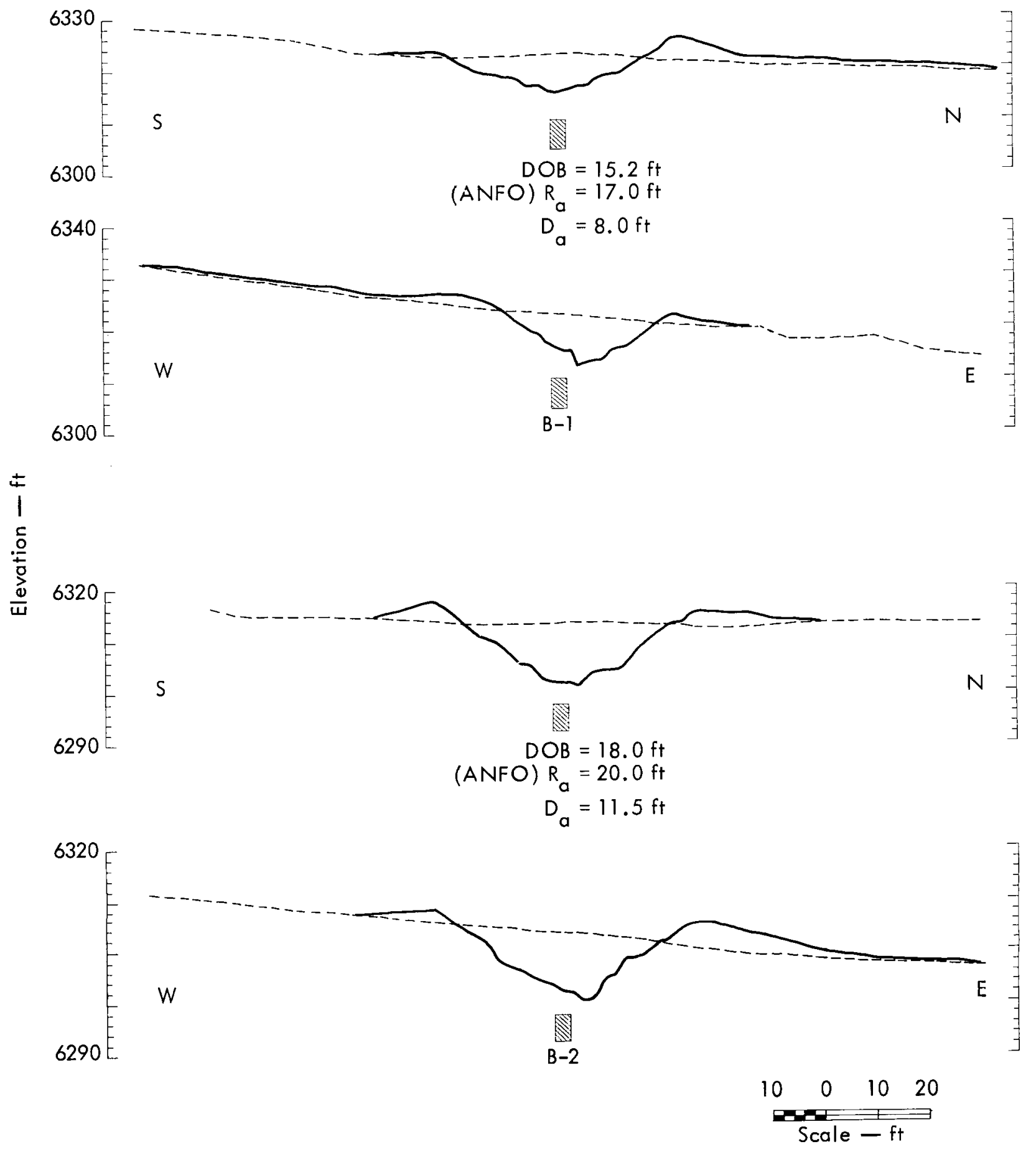

Fig. B2. Cross sections of Craters B1 and B2. 


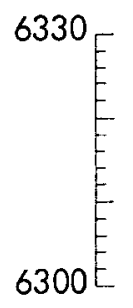

S

$$
\begin{aligned}
D O B & =19.7 \mathrm{ft} \\
(A N F O) R_{a} & =24.0 \mathrm{ft} \\
D_{a} & =6.5 \mathrm{ft}
\end{aligned}
$$
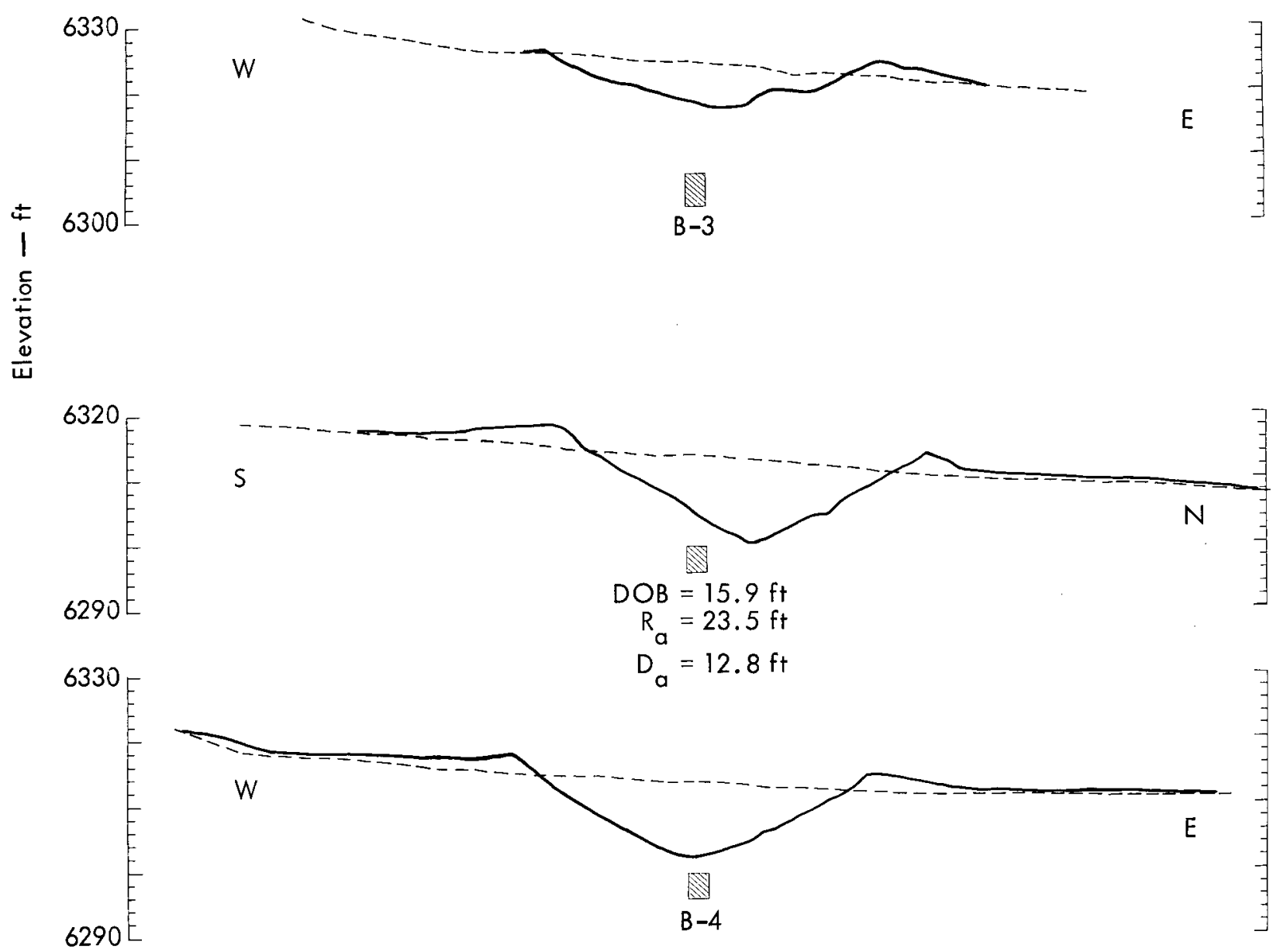

$$
\frac{10 \quad 0 \quad 10 \quad 20}{\text { Scale }-\mathrm{ft}}
$$

Fig. B3. Cross sections of Craters B3 and B4. 

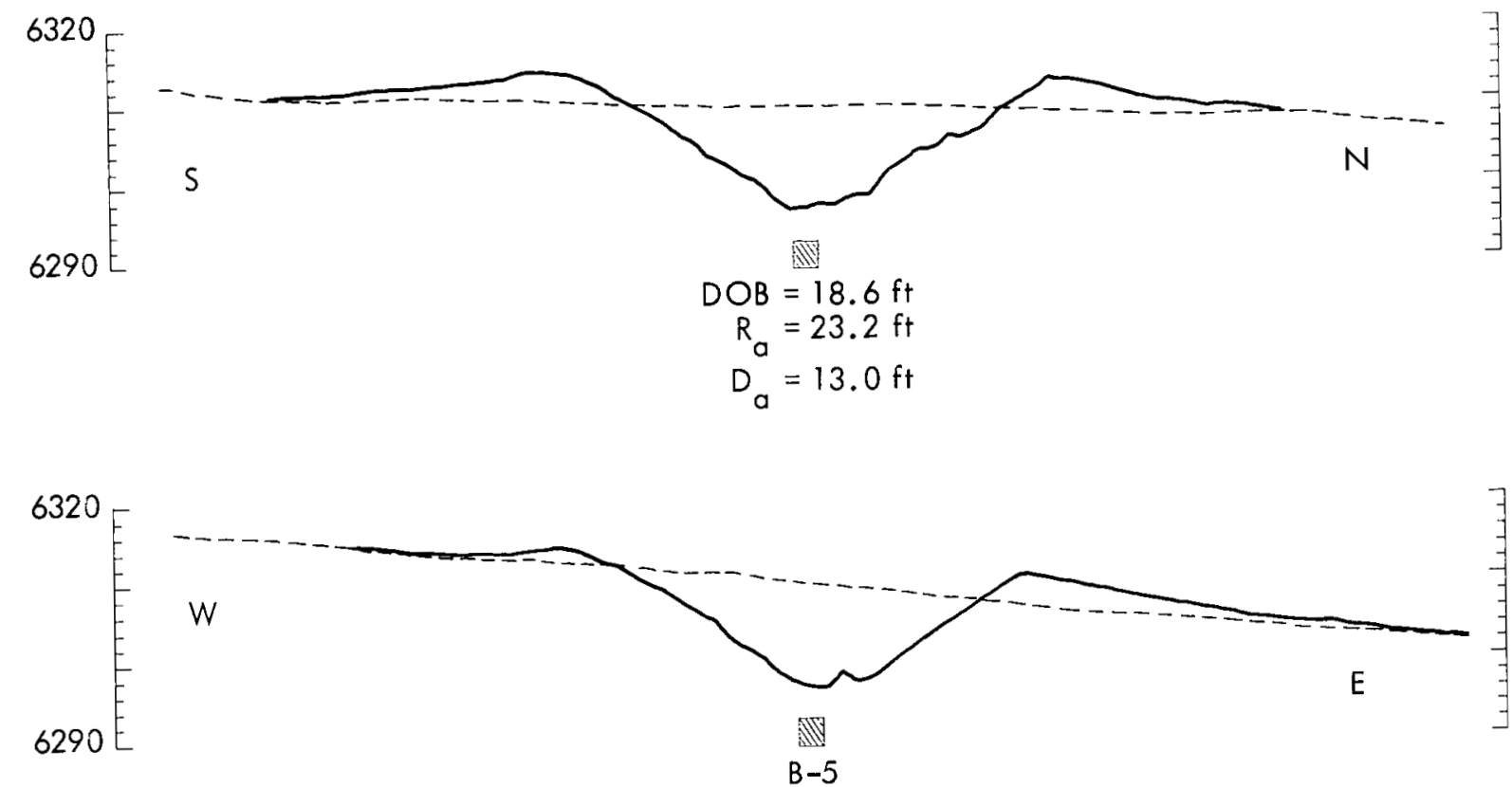

$\frac{4}{4}$
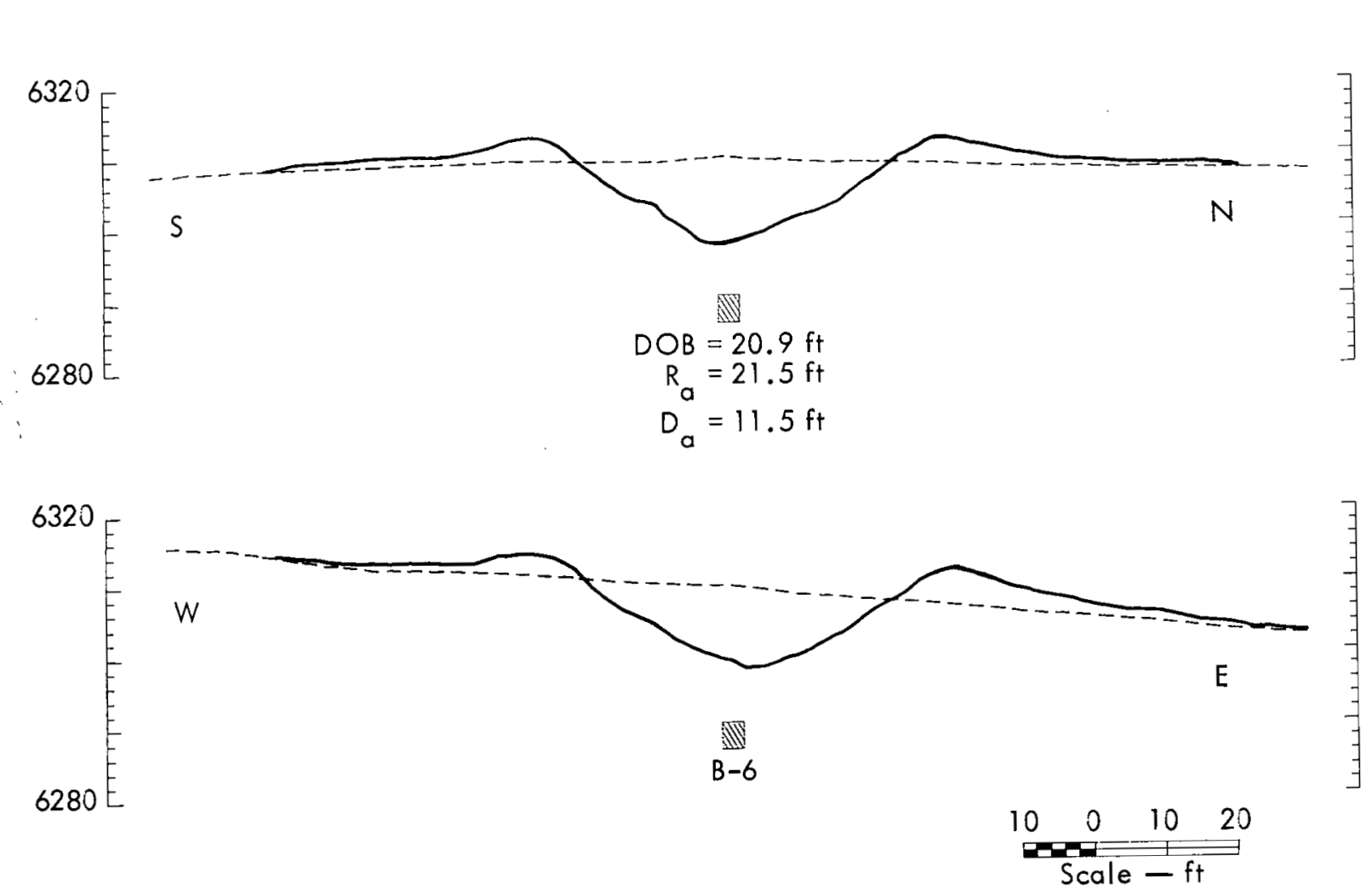

Fig. B4. Cross sections of Craters B5 and B6. 

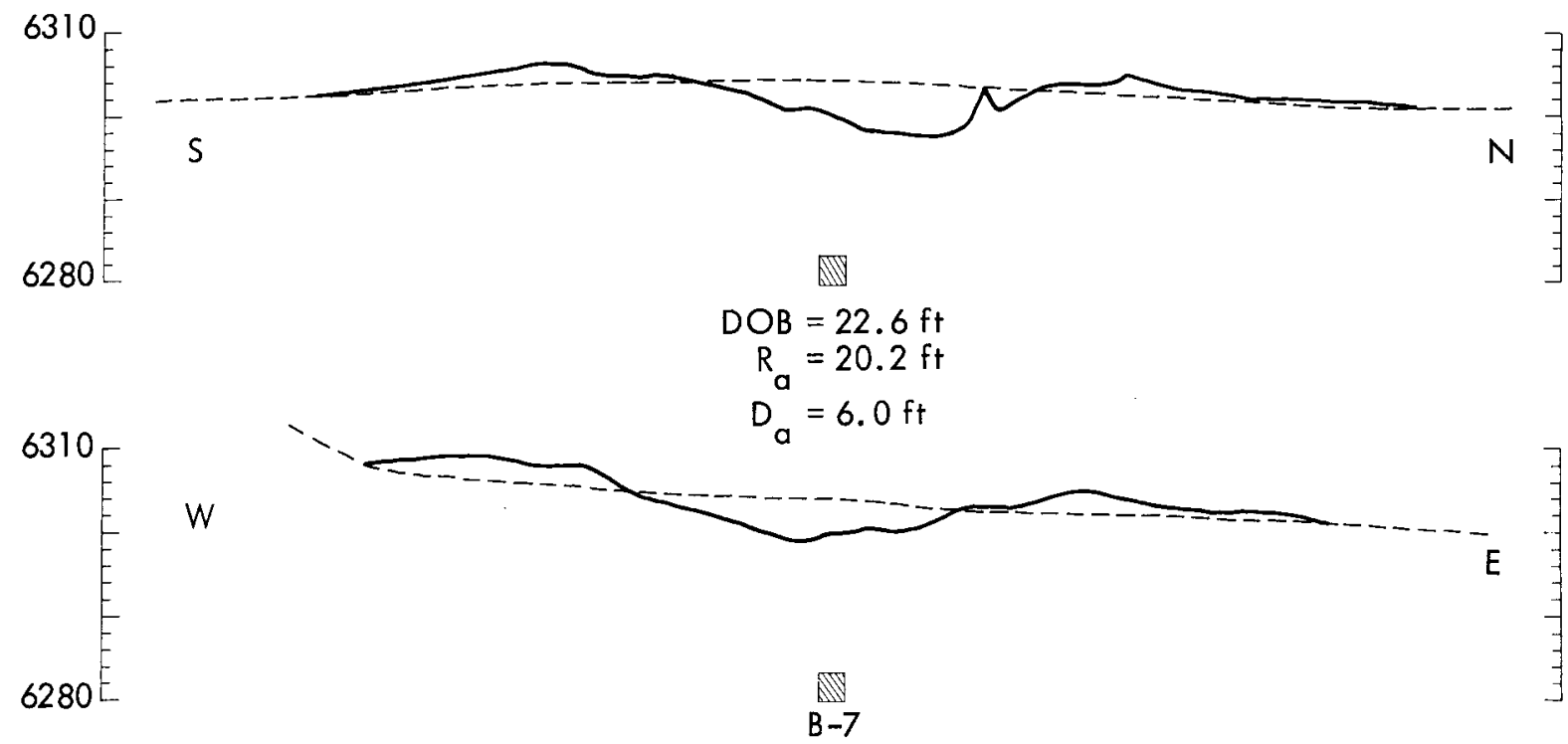

$\frac{\sqrt{4}}{1}$
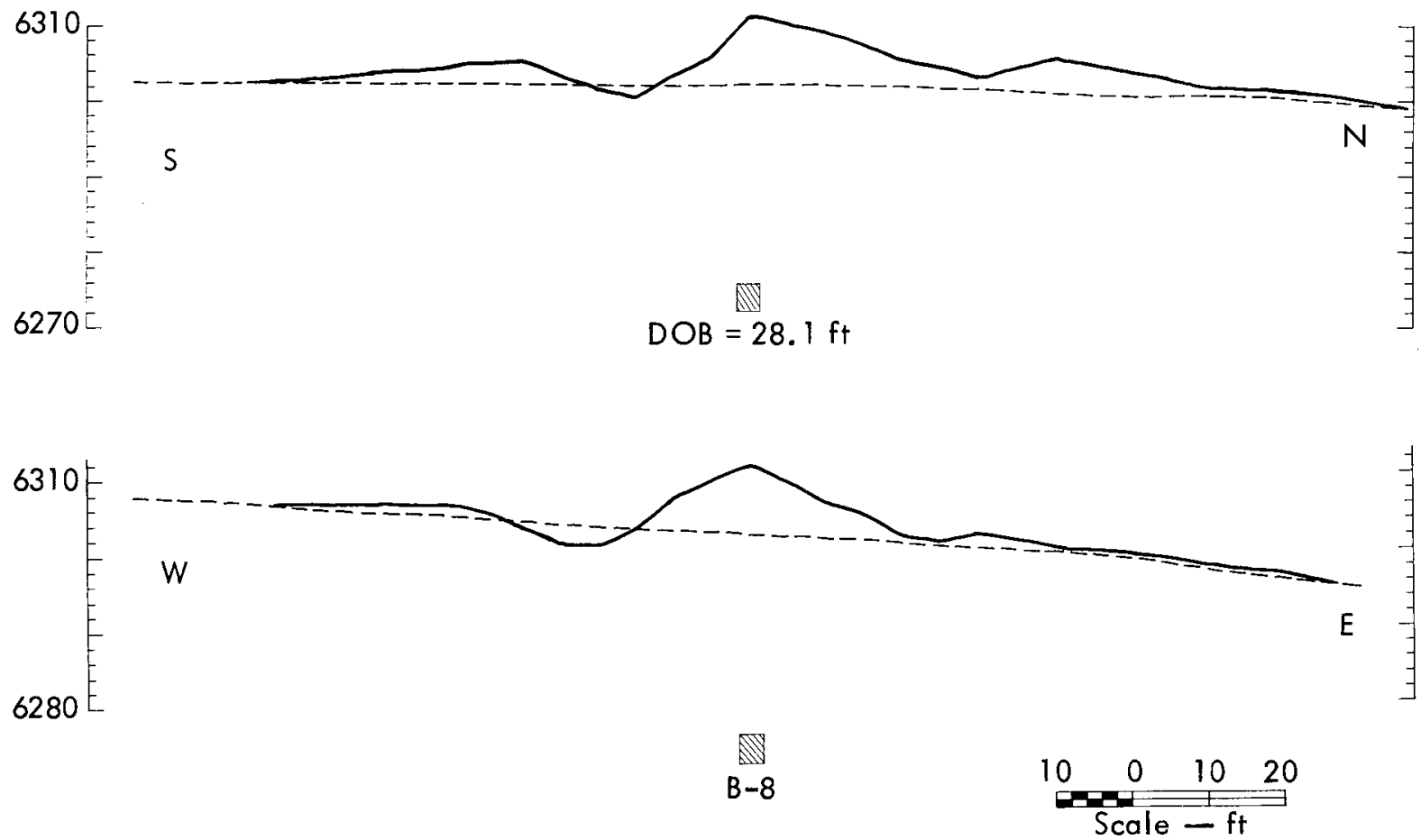

Fig. B5. Cross sections of Craters B7 and B8. 

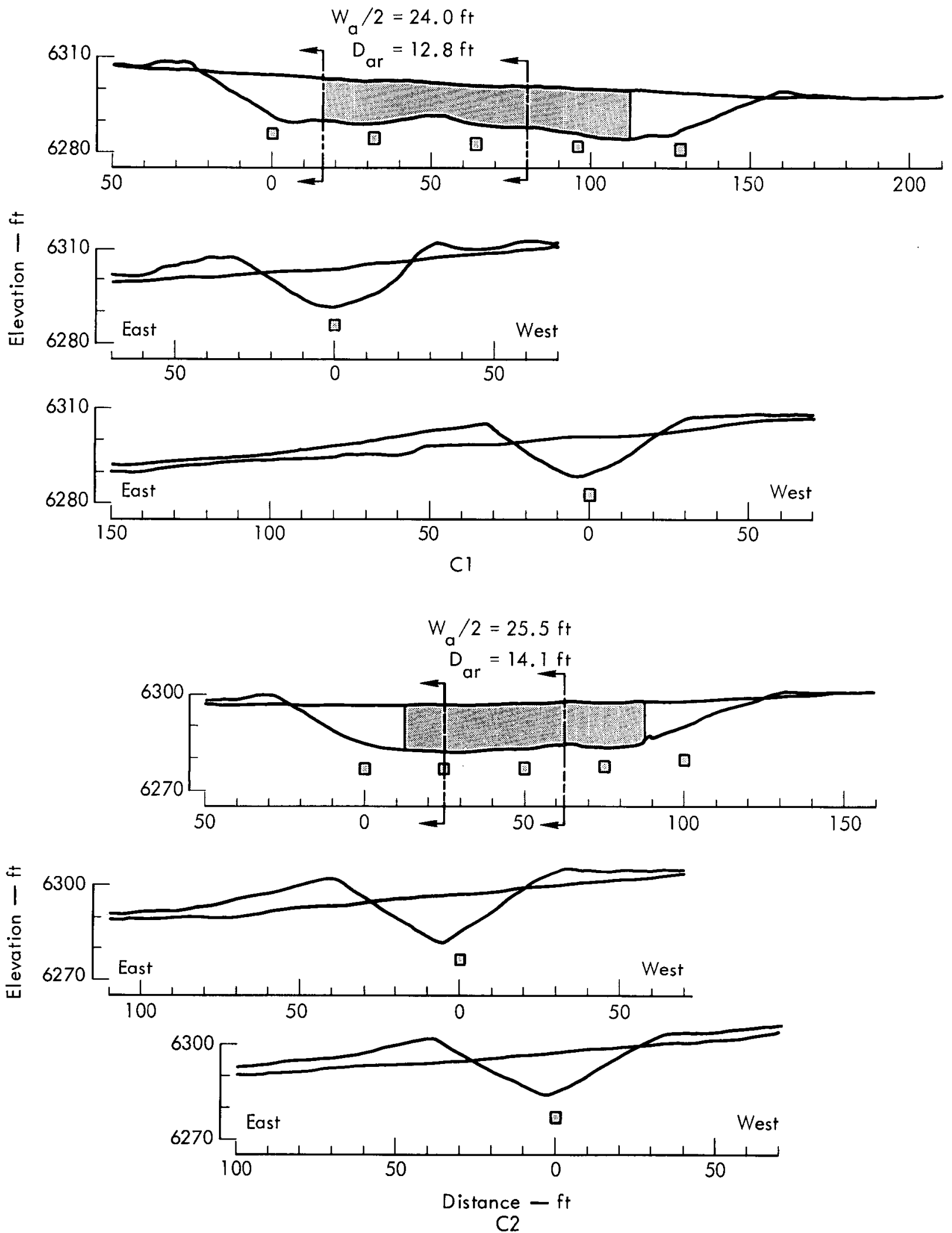

Fig. B.6. Longitudinal profiles and representative cross sections for Rows $\mathrm{C} 1$ and $\mathrm{C} 2$. 

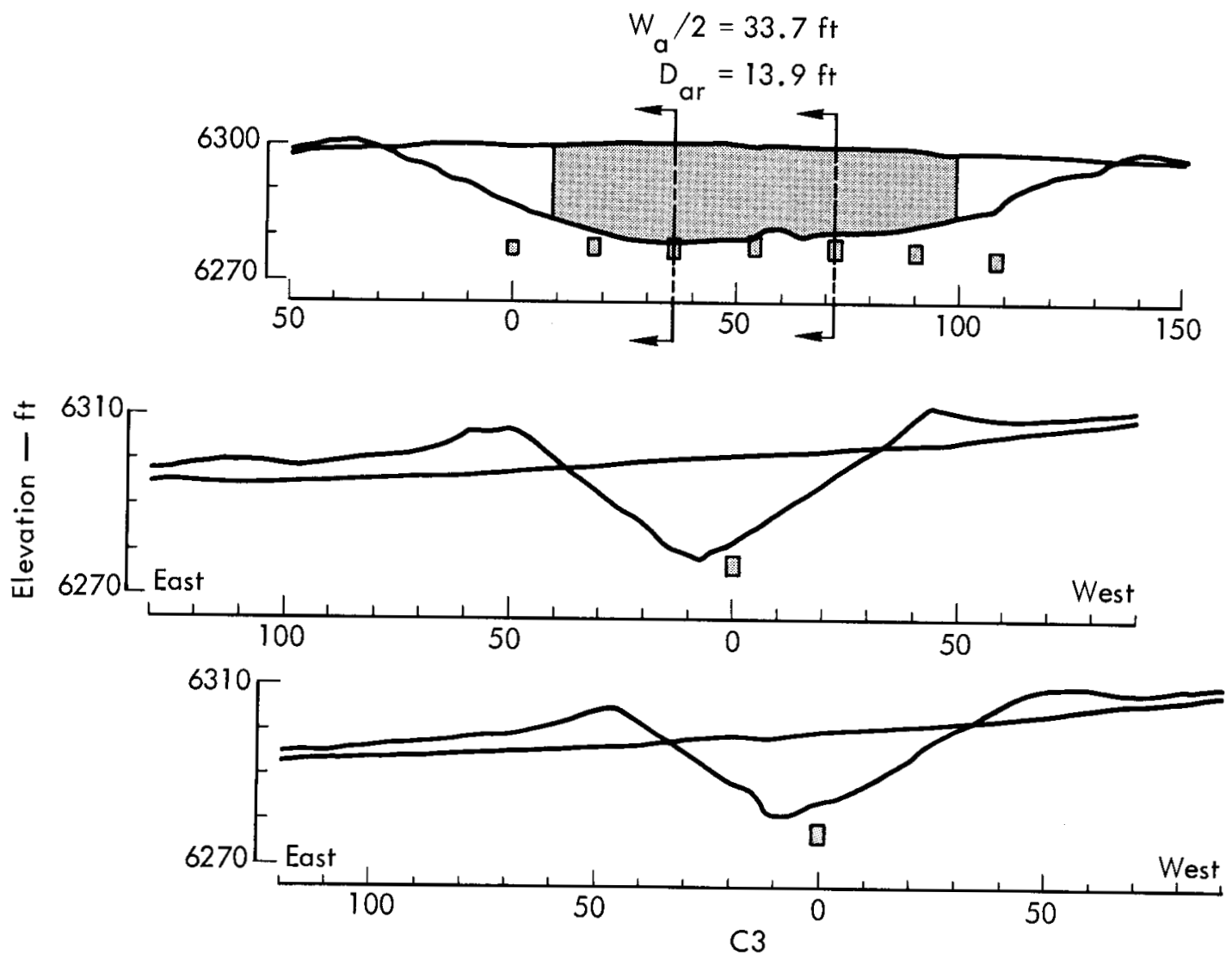

Fig. B7. Longitudinal profile and representative cross sections for Row C3. 

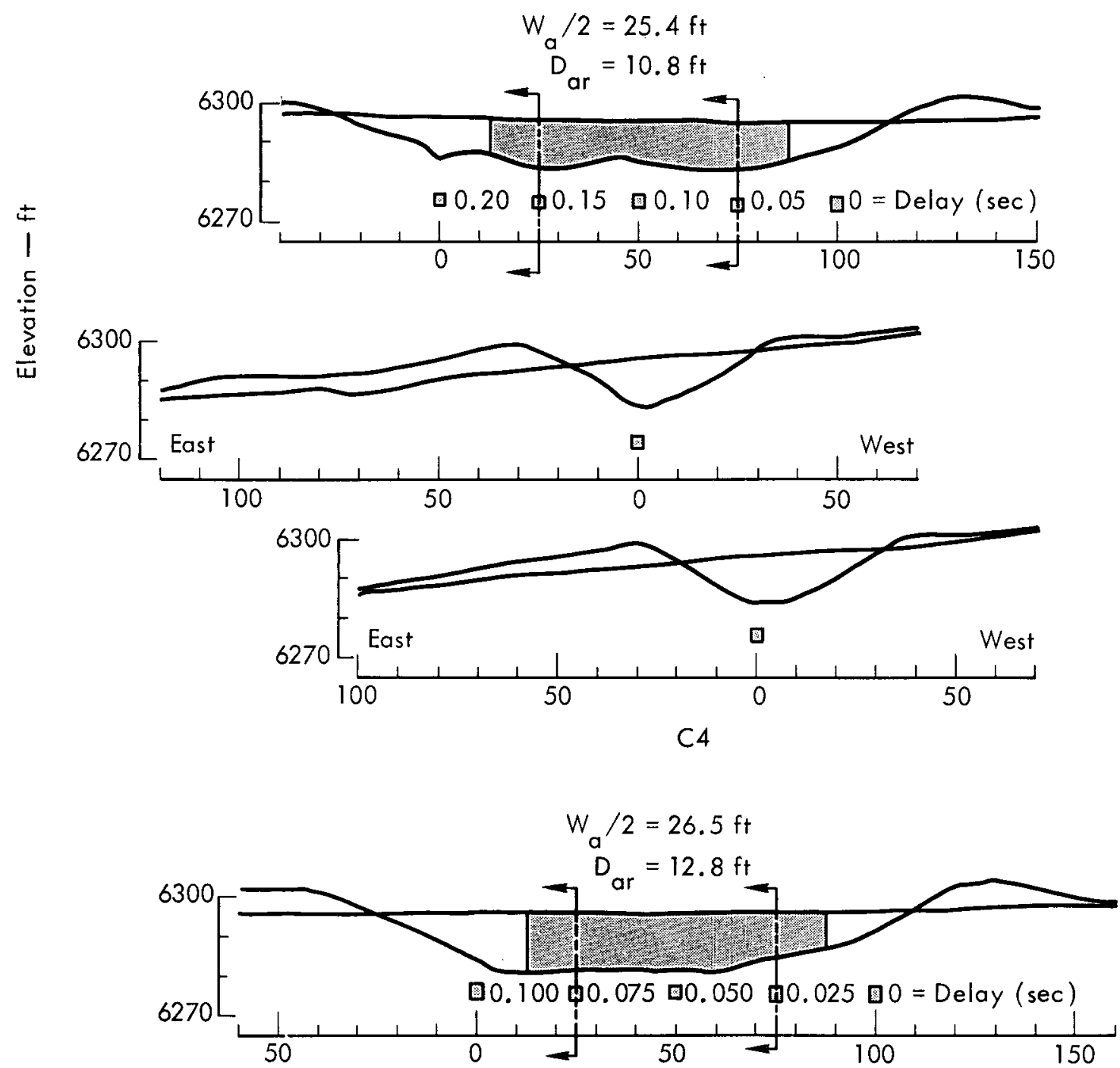

$\frac{1}{1}$
$\frac{5}{0}$
$\frac{9}{0}$
$\frac{0}{4}$
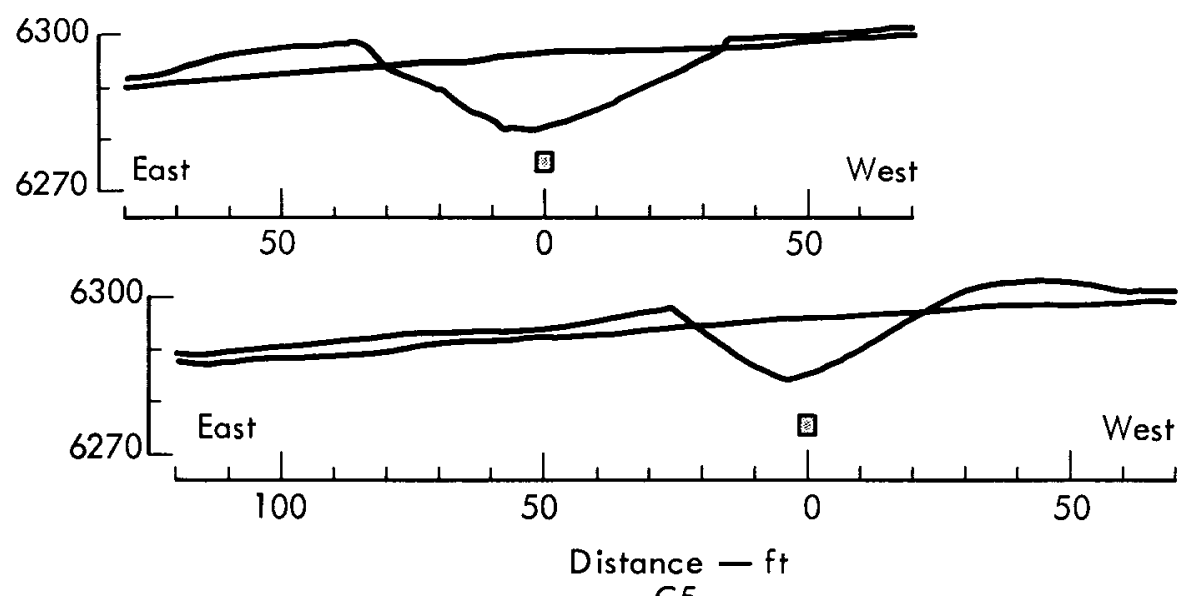

C5

Fig. B8. Longitudinal profiles and representative cross sections for Rows C4 and $\mathrm{C} 5$. 


\section{Appendix C Seismic Data}

This appendix tabulates all values of peak particle velocity recorded during Project Trinidad. The loca- tions of the recording stations and the station-shot distances are given in Chapter 4.

Table C1. Maximum recorded particle velocities for B-series. (All values to be multiplied by $10^{-3}$.)

\begin{tabular}{|c|c|c|c|c|c|c|c|c|c|}
\hline \multirow[b]{2}{*}{ Station } & \multirow[b]{2}{*}{ Component } & \multicolumn{3}{|c|}{$\mathrm{ANFO}$} & \multicolumn{5}{|c|}{ AANS (TD-2) } \\
\hline & & $\begin{array}{c}\mathrm{B} 1 \\
(\mathrm{~cm} / \mathrm{sec})\end{array}$ & $\begin{array}{c}\mathrm{B} 2 \\
(\mathrm{~cm} / \mathrm{sec})\end{array}$ & $\begin{array}{c}\mathrm{B} 3 \\
(\mathrm{~cm} / \mathrm{sec})\end{array}$ & $\begin{array}{c}\mathrm{B} 4 \\
(\mathrm{~cm} / \mathrm{sec})\end{array}$ & $\begin{array}{c}\mathrm{B} 5 \\
(\mathrm{~cm} / \mathrm{sec})\end{array}$ & $\begin{array}{c}\mathrm{B6} \\
(\mathrm{cm} / \mathrm{sec})\end{array}$ & $\begin{array}{c}\mathrm{B} 7 \\
(\mathrm{~cm} / \mathrm{sec})\end{array}$ & $\begin{array}{c}\mathrm{B} 8 \\
(\mathrm{~cm} / \mathrm{sec})\end{array}$ \\
\hline GM - 1 & $\begin{array}{l}\text { Vertical } \\
\text { Radial } \\
\text { Transverse }\end{array}$ & $\begin{array}{l}2.8 \\
2.3 \\
2.3\end{array}$ & $\begin{array}{l}3.7 \\
1.6 \\
4.1\end{array}$ & $\begin{array}{l}3.4 \\
3.2 \\
4.3\end{array}$ & $\begin{array}{l}4.8 \\
2.2 \\
2.2\end{array}$ & $\begin{array}{l}5.7 \\
3.0 \\
4.2\end{array}$ & $\begin{array}{r}-^{a} \\
-a \\
-\end{array}$ & $\begin{array}{l}4.9 \\
2.4 \\
2.0\end{array}$ & $\begin{array}{r}{ }^{a} \\
-a \\
-a\end{array}$ \\
\hline GM-2 & $\begin{array}{l}\text { Vertical } \\
\text { Radial } \\
\text { Transverse }\end{array}$ & $\begin{array}{r}85 \\
120 \\
90\end{array}$ & $\begin{array}{r}75 \\
110 \\
60\end{array}$ & $\begin{array}{r}85 \\
130 \\
90\end{array}$ & $\begin{array}{r}95 \\
120 \\
50\end{array}$ & $\begin{array}{r}115 \\
170 \\
70\end{array}$ & $\begin{array}{l}100 \\
160 \\
100\end{array}$ & $\begin{array}{l}120 \\
140 \\
110\end{array}$ & $\begin{array}{l}160 \\
210 \\
150\end{array}$ \\
\hline GM-3 & $\begin{array}{l}\text { Vertical } \\
\text { Radial } \\
\text { Transverse }\end{array}$ & $\begin{array}{l}38 \\
18 \\
24\end{array}$ & $\begin{array}{l}41 \\
20 \\
28\end{array}$ & $\begin{array}{l}46 \\
26 \\
26\end{array}$ & $\begin{array}{l}48 \\
19 \\
20\end{array}$ & $\begin{array}{l}63 \\
27 \\
37\end{array}$ & $\begin{array}{l}50 \\
25 \\
25\end{array}$ & $\begin{array}{l}50 \\
20 \\
24\end{array}$ & $\begin{array}{l}68 \\
30 \\
42\end{array}$ \\
\hline$S R-1$ & $\begin{array}{l}\text { Vertical } \\
\text { Radial } \\
\text { Transverse }\end{array}$ & $\begin{array}{l}9.0 \\
7.0 \\
9.0\end{array}$ & $\begin{array}{l}4.0 \\
8.5 \\
7.0\end{array}$ & $\begin{array}{l}3.0 \\
7.0 \\
8.0\end{array}$ & $\begin{array}{l}5.6 \\
9.2 \\
4.0\end{array}$ & $\begin{array}{c}8.0 \\
17 \\
2.0\end{array}$ & $\begin{array}{c}a \\
Z^{a}\end{array}$ & $\begin{array}{c}7.5 \\
14 \\
8.0\end{array}$ & $\begin{array}{l}{ }_{-a}^{a} \\
-^{a}\end{array}$ \\
\hline$S R-2$ & $\begin{array}{l}\text { Vertical } \\
\text { Radial } \\
\text { Transverse }\end{array}$ & $\begin{array}{l}2.5 \\
2.4 \\
2.4\end{array}$ & $\begin{array}{l}3.3 \\
2.1 \\
3.8\end{array}$ & $\begin{array}{l}2.5 \\
3.7 \\
3.7\end{array}$ & $\begin{array}{l}3.7 \\
2.5 \\
2.0\end{array}$ & $\begin{array}{l}4.8 \\
3.2 \\
4.0\end{array}$ & $\begin{array}{l}-a \\
-a\end{array}$ & $\begin{array}{l}4.5 \\
3.0 \\
2.5\end{array}$ & $\begin{array}{l}E^{a} \\
-^{a}\end{array}$ \\
\hline
\end{tabular}

${ }^{\mathrm{a}}$ Unreliable.

Table C2. Maximum recorded particle velocities for C1, C2, C3. (All values to be multiplied by $10^{-3}$ ).

\begin{tabular}{|c|c|c|c|c|c|c|c|c|c|c|}
\hline \multirow[b]{2}{*}{ Station } & \multirow[b]{2}{*}{ Component } & \multicolumn{3}{|c|}{$\mathrm{Cl}$} & \multicolumn{3}{|c|}{$\mathrm{C} 2$} & \multicolumn{3}{|c|}{ C3 } \\
\hline & & $\begin{array}{c}\text { Compressional } \\
(\mathrm{cm} / \mathrm{sec})\end{array}$ & $\begin{array}{l}\text { Shear } \\
(\mathrm{cm} / \mathrm{sec})\end{array}$ & $\begin{array}{l}\text { Surface } \\
(\mathrm{cm} / \mathrm{sec})\end{array}$ & $\begin{array}{l}\text { Compressional } \\
(\mathrm{cm} / \mathrm{sec})\end{array}$ & $\begin{array}{l}\text { Shear } \\
(\mathrm{cm} / \mathrm{sec})\end{array}$ & $\begin{array}{l}\text { Surface } \\
(\mathrm{cm} / \mathrm{sec})\end{array}$ & $\begin{array}{c}\text { Compressional } \\
(\mathrm{cm} / \mathrm{sec})\end{array}$ & $\begin{array}{l}\text { Shear } \\
(\mathrm{cm} / \mathrm{sec})\end{array}$ & $\begin{array}{c}\text { Surface } \\
(\mathrm{cm} / \mathrm{sec})\end{array}$ \\
\hline GM - 1 & $\begin{array}{l}\mathrm{V} \\
\mathrm{R} \\
\mathrm{T}\end{array}$ & $\begin{array}{l}9.5 \\
5.0 \\
4.0\end{array}$ & $\begin{array}{l}7.0 \\
6.0 \\
11\end{array}$ & $\begin{array}{r}17 \\
7.5 \\
9.0\end{array}$ & $\begin{array}{r}10 \\
5.5 \\
3.5\end{array}$ & $\begin{array}{l}8.5 \\
12 \\
14\end{array}$ & $\begin{array}{c}16 \\
8.2 \\
10\end{array}$ & $\begin{array}{c}15 \\
8.5 \\
5.0\end{array}$ & $\begin{array}{l}12 \\
19 \\
12\end{array}$ & $\begin{array}{l}25 \\
10 \\
14\end{array}$ \\
\hline GM-2 & $\begin{array}{l}\mathrm{V} \\
\mathrm{R} \\
\mathrm{T}\end{array}$ & $\begin{array}{r}80 \\
180 \\
80\end{array}$ & $\begin{array}{l}100 \\
400 \\
270\end{array}$ & $\begin{array}{l}340 \\
400 \\
200\end{array}$ & $\begin{array}{l}120 \\
250 \\
100\end{array}$ & $\begin{array}{l}150 \\
310 \\
400\end{array}$ & $\begin{array}{l}450 \\
470 \\
120\end{array}$ & $\begin{array}{l}230 \\
460 \\
200\end{array}$ & $\begin{array}{l}160 \\
430 \\
480\end{array}$ & $\begin{array}{l}660 \\
540 \\
210\end{array}$ \\
\hline GM-3 & $\begin{array}{l}\mathrm{V} \\
\mathrm{K} \\
\mathrm{T}\end{array}$ & $\begin{array}{l}73 \\
60 \\
25\end{array}$ & $\begin{array}{l}85 \\
82 \\
75\end{array}$ & $\begin{array}{r}170 \\
85 \\
90\end{array}$ & $\begin{array}{l}75 \\
70 \\
30\end{array}$ & $\begin{array}{r}100 \\
70 \\
85\end{array}$ & $\begin{array}{r}150 \\
85 \\
75\end{array}$ & $\begin{array}{l}90 \\
85 \\
20\end{array}$ & $\begin{array}{r}100 \\
55 \\
85\end{array}$ & $\begin{array}{r}225 \\
60 \\
95\end{array}$ \\
\hline $\mathrm{SR}-1$ & $\begin{array}{l}\mathrm{V} \\
\mathrm{R} \\
\mathrm{T}\end{array}$ & $\begin{array}{c}22 \\
9.0 \\
5.0\end{array}$ & ${\overline{\bar{C}^{a}}}^{\mathrm{a}}$ & $\begin{array}{l}22 \\
37 \\
18\end{array}$ & $\begin{array}{r}25 \\
9.0 \\
7.0\end{array}$ & $\begin{array}{r}26 \\
\text { - }^{a}\end{array}$ & $\begin{array}{l}17 \\
38 \\
25\end{array}$ & $\begin{array}{l}32 \\
10 \\
7.0\end{array}$ & $\begin{array}{l}30 \\
-a \\
-\end{array}$ & $\begin{array}{l}23 \\
57 \\
36\end{array}$ \\
\hline $\mathrm{SR}-2$ & $\begin{array}{l}\mathrm{V} \\
\mathrm{R} \\
\mathrm{T}\end{array}$ & $\begin{array}{l}9.5 \\
8.2 \\
5.5\end{array}$ & $\overline{-}^{a}$ & $\begin{array}{c}16 \\
10 \\
8.3\end{array}$ & $\begin{array}{l}7.8 \\
7.5 \\
7.5\end{array}$ & $\overline{-}_{20}^{\mathbf{a}}$ & $\begin{array}{c}15 \\
12 \\
9.0\end{array}$ & $\begin{array}{c}11 \\
12 \\
9.0\end{array}$ & $\overline{-}^{\mathrm{a}}$ & $\begin{array}{l}20 \\
14 \\
14\end{array}$ \\
\hline
\end{tabular}

\footnotetext{
${ }^{a}$ Unreliable.
} 
Table C3. Maximum recorded particle velocities for $\mathrm{C} 4, \mathrm{C} 5, \mathrm{C} 6$. (All values to be multiplied by $10^{-3}$ ).

\begin{tabular}{|c|c|c|c|c|c|c|c|c|c|c|}
\hline \multirow[b]{2}{*}{ Station } & \multirow[b]{2}{*}{ Component } & \multicolumn{3}{|c|}{ C4 } & \multicolumn{3}{|c|}{$\mathrm{C5}$} & \multicolumn{3}{|c|}{ C6 } \\
\hline & & $\begin{array}{l}\text { Compressional } \\
(\mathrm{cm} / \mathrm{sec})\end{array}$ & $\begin{array}{c}\text { Shear } \\
\{\mathrm{cm} / \mathrm{sec})\end{array}$ & $\begin{array}{l}\text { Surface } \\
(\mathrm{cm} / \mathrm{sec})\end{array}$ & $\begin{array}{c}\text { Compressional } \\
(\mathrm{cm} / \mathrm{sec})\end{array}$ & $\begin{array}{c}\text { Shear } \\
(\mathrm{cm} / \mathrm{sec})\end{array}$ & $\begin{array}{l}\text { Surface } \\
(\mathrm{cm} / \mathrm{sec})\end{array}$ & $\begin{array}{c}\text { Compressional } \\
(\mathrm{cm} / \mathrm{sec})\end{array}$ & $\begin{array}{l}\text { Shear } \\
(\mathrm{cm} / \mathrm{sec})\end{array}$ & $\begin{array}{l}\text { Surlace } \\
\text { lcmisecl }\end{array}$ \\
\hline GM-1 & $\begin{array}{l}\mathrm{V} \\
\mathrm{R} \\
\mathrm{T}\end{array}$ & $\begin{array}{l}4.1 \\
2.0 \\
1.2\end{array}$ & $\begin{array}{l}1.8 \\
3.1 \\
3.0\end{array}$ & $\begin{array}{l}4.1 \\
2.0 \\
1.7\end{array}$ & $\begin{array}{l}3.3 \\
2.0 \\
1.5\end{array}$ & $\begin{array}{l}3.0 \\
3.3 \\
3.4\end{array}$ & $\begin{array}{l}6.5 \\
3.9 \\
4.1\end{array}$ & $\begin{array}{c}16 \\
9.0 \\
7.0\end{array}$ & $\begin{array}{l}16 \\
28 \\
15\end{array}$ & $\begin{array}{l}35 \\
15 \\
13\end{array}$ \\
\hline GM-2 & $\begin{array}{l}V \\
R \\
T\end{array}$ & $\begin{array}{l}40 \\
80 \\
40\end{array}$ & $\begin{array}{r}50 \\
120 \\
140\end{array}$ & $\begin{array}{l}150 \\
130 \\
110\end{array}$ & $\begin{array}{l}{ }^{a} \\
-a \\
-a\end{array}$ & $\overline{-}^{a}{ }^{a}{ }^{a}$ & $\begin{array}{r}\tilde{-a}^{a} \\
\overline{-}^{a}\end{array}$ & $\begin{array}{l}250 \\
580 \\
140\end{array}$ & $\begin{array}{l}250 \\
520 \\
700\end{array}$ & $\begin{array}{l}6500 \\
700 \\
300\end{array}$ \\
\hline GM -3 & $\begin{array}{l}\mathrm{V} \\
\mathrm{R} \\
\mathrm{T}\end{array}$ & $\begin{array}{c}32 \\
25 \\
8.0\end{array}$ & $\begin{array}{l}32 \\
18 \\
15\end{array}$ & $\begin{array}{l}47 \\
17 \\
20\end{array}$ & $\begin{array}{l}27 \\
30 \\
10\end{array}$ & $\begin{array}{l}60 \\
35 \\
18\end{array}$ & $\begin{array}{l}45 \\
20 \\
25\end{array}$ & $\begin{array}{r}130 \\
130 \\
30\end{array}$ & $\begin{array}{l}160 \\
130 \\
100\end{array}$ & $\begin{array}{r}310 \\
80 \\
110\end{array}$ \\
\hline $\mathrm{SR}-1$ & $\begin{array}{l}\mathrm{V} \\
\mathrm{R} \\
\mathrm{T}\end{array}$ & $\begin{array}{l}9.0 \\
3.0 \\
3.0\end{array}$ & $\begin{array}{l}5.5 \\
-b\end{array}$ & $\begin{array}{l}7.5 \\
9.0 \\
9.0\end{array}$ & $\begin{array}{l}8.0 \\
3.5 \\
1.0\end{array}$ & ${ }^{11}{ }_{b}$ & $\begin{array}{c}13 \\
21 \\
3.5\end{array}$ & $\begin{array}{l}38 \\
14 \\
7.0\end{array}$ & $\frac{6}{25}$ & $\begin{array}{l}50 \\
47 \\
44\end{array}$ \\
\hline$S R-2$ & $\begin{array}{l}\mathrm{V} \\
\mathrm{R} \\
\mathrm{T}\end{array}$ & $\begin{array}{l}2.3 \\
3.8 \\
2.4\end{array}$ & $\frac{b}{-b}$ & $\begin{array}{l}3.4 \\
2.9 \\
1.8\end{array}$ & $\begin{array}{l}2.5 \\
3.9 \\
4.0\end{array}$ & $\frac{-b}{5.0}$ & $\begin{array}{l}6.4 \\
5.4 \\
3.7\end{array}$ & $\begin{array}{l}12 \\
13 \\
11\end{array}$ & $-\frac{6}{25}$ & $\begin{array}{l}37 \\
21 \\
17\end{array}$ \\
\hline
\end{tabular}

a Data not recorded.

${ }^{b}$ Unretiable. 
Table C4. Maximum recorded particle velocities for D series. (All values to be multiplied by $10^{-3}$ ).

\begin{tabular}{|c|c|c|c|c|c|c|c|c|c|c|c|c|c|}
\hline \multirow[b]{2}{*}{ Station } & \multirow[b]{2}{*}{ Component } & \multicolumn{3}{|c|}{$\mathrm{D} 1$} & \multicolumn{3}{|c|}{ D2 } & \multicolumn{3}{|c|}{ D3 } & \multicolumn{3}{|c|}{ D4 } \\
\hline & & $\begin{array}{c}\text { Compressional } \\
(\mathrm{cm} / \mathrm{sec})\end{array}$ & $\begin{array}{c}\text { Shear } \\
(\mathrm{cm} / \mathrm{sec})\end{array}$ & $\begin{array}{l}\text { Surface } \\
(\mathrm{cm} / \mathrm{sec})\end{array}$ & $\begin{array}{c}\text { Compressional } \\
(\mathrm{cm} / \mathrm{sec})\end{array}$ & $\begin{array}{c}\text { Shear } \\
(\mathrm{cm} / \mathrm{sec})\end{array}$ & $\begin{array}{l}\text { Surface } \\
(\mathrm{cm} / \mathrm{sec})\end{array}$ & $\begin{array}{c}\text { Compressional } \\
(\mathrm{cm} / \mathrm{sec})\end{array}$ & $\begin{array}{c}\text { Shear } \\
(\mathrm{cm} / \mathrm{sec})\end{array}$ & $\begin{array}{c}\text { Surface } \\
(\mathrm{cm} / \mathrm{sec})\end{array}$ & $\begin{array}{l}\text { Compressional } \\
(\mathrm{cm} / \mathrm{sec})\end{array}$ & $\begin{array}{c}\text { Shear } \\
(\mathrm{cm} / \mathrm{sec})\end{array}$ & $\begin{array}{c}\text { Surface } \\
(\mathrm{cm} / \mathrm{sec})\end{array}$ \\
\hline$G M-1$ & $\begin{array}{l}\mathrm{V} \\
\mathrm{R} \\
\mathrm{T}\end{array}$ & $\begin{array}{l}8.5 \\
8.9 \\
3.3\end{array}$ & $\begin{array}{l}62 \\
33 \\
18\end{array}$ & $\begin{array}{c}54 \\
23 \\
6.0\end{array}$ & $\begin{array}{l}6.0 \\
7.0 \\
3.0\end{array}$ & $\begin{array}{l}40 \\
26 \\
51\end{array}$ & $\begin{array}{l}46 \\
22 \\
11\end{array}$ & $\begin{array}{l}8.0 \\
6.0 \\
-\end{array}$ & $\begin{array}{l}92 \\
55 \\
92\end{array}$ & $\begin{array}{l}82 \\
48 \\
46\end{array}$ & $\begin{array}{l}16 \\
12_{2} \\
-\end{array}$ & $\begin{array}{l}28 \\
40 \\
40\end{array}$ & $\begin{array}{l}60 \\
25 \\
20\end{array}$ \\
\hline GM-2 & $\begin{array}{l}\mathrm{V} \\
\mathrm{R} \\
\mathrm{T}\end{array}$ & $\begin{array}{l}D^{b} \\
\beth^{b}\end{array}$ & $\begin{array}{l}b \\
-b \\
-b\end{array}$ & $\begin{array}{l}\mathrm{b} \\
\stackrel{\mathrm{b}}{\mathrm{b}} \\
-\end{array}$ & $\begin{array}{l}\mathrm{b} \\
\mathrm{D}_{\mathrm{b}}^{\mathrm{b}}\end{array}$ & $\begin{array}{l}-\mathrm{b} \\
-\mathrm{b} \\
-\mathrm{b}\end{array}$ & $\begin{array}{l}\stackrel{b}{b} \\
\underset{b}{b}\end{array}$ & $\begin{array}{l}\mathrm{b}^{\mathrm{b}} \\
-\mathrm{b}\end{array}$ & $\begin{array}{l}\mathrm{b} \\
\beth^{b} \\
-b\end{array}$ & $\begin{array}{l}\mathrm{b} \\
-\mathrm{b} \\
-\mathrm{b}\end{array}$ & $\begin{array}{r}400 \\
1200 \\
600\end{array}$ & $\begin{array}{l}{ }^{a} \\
\overline{-a}^{a}\end{array}$ & $\begin{array}{r}1500 \\
1200 \\
800\end{array}$ \\
\hline GM-4 & $\begin{array}{l}\mathrm{V} \\
\mathrm{R} \\
\mathrm{T}\end{array}$ & $\begin{array}{r}130 \\
100 \\
50\end{array}$ & $\begin{array}{r}70 \\
280 \\
280\end{array}$ & $\begin{array}{l}300 \\
520 \\
700\end{array}$ & $\begin{array}{l}50 \\
70 \\
40\end{array}$ & $\begin{array}{r}200 \\
\underline{-}^{a}\end{array}$ & $\begin{array}{l}480 \\
700 \\
430\end{array}$ & $\begin{array}{c}100 \\
50 \\
-\end{array}$ & $\begin{array}{l}\text { - }^{\mathrm{a}} \\
\text { - }^{\mathrm{a}}\end{array}$ & $\begin{array}{l}400 \\
870 \\
320\end{array}$ & $\begin{array}{l}{ }_{-b}^{b} \\
{ }_{-b}^{b}\end{array}$ & $\begin{array}{l}-_{b}^{b} \\
-b \\
-b\end{array}$ & $E^{b}$ \\
\hline SR - 1 & $\begin{array}{l}\mathrm{V} \\
\mathrm{R} \\
\mathrm{T}\end{array}$ & $\begin{array}{l}20 \\
6.0 \\
4.0\end{array}$ & $\begin{array}{l}87{ }_{a} \\
-{ }^{a} \\
-\end{array}$ & $\begin{array}{l}90 \\
92 \\
18\end{array}$ & $\begin{array}{c}20 \\
\text { - }^{a}\end{array}$ & $\begin{array}{l}60 \\
60 \\
60\end{array}$ & $\begin{array}{l}90 \\
95 \\
50\end{array}$ & $\begin{array}{l}30 \mathrm{a} \\
-\mathrm{a}\end{array}$ & $\begin{array}{r}175 \\
80 \\
120\end{array}$ & $\begin{array}{l}160 \\
180 \\
100\end{array}$ & $\begin{array}{l}-_{a}^{a} \\
z^{a}\end{array}$ & $\overline{-}_{100}^{a}$ & $\begin{array}{r}70 \\
110 \\
100\end{array}$ \\
\hline SR-2 & $\begin{array}{l}\mathrm{V} \\
\mathrm{R} \\
\mathrm{T}\end{array}$ & $\begin{array}{l}7.3 \\
6.5 \\
5.0\end{array}$ & $\begin{array}{l}61 \\
27 \\
20\end{array}$ & $\begin{array}{l}48 \\
36 \\
17\end{array}$ & $\begin{array}{l}8.0 \\
7.0 \\
6.0\end{array}$ & $\begin{array}{l}45 \\
28 \\
47\end{array}$ & $\begin{array}{l}45 \\
31 \\
17\end{array}$ & $\begin{array}{l}7.0 \\
7.0 \\
6.0\end{array}$ & $\begin{array}{r}88 \\
70 \\
103\end{array}$ & $\begin{array}{l}83 \\
60 \\
40\end{array}$ & $\begin{array}{l}20 \\
13 \\
10\end{array}$ & $\begin{array}{l}28 \\
33 \\
37\end{array}$ & $\begin{array}{l}60 \\
25 \\
13\end{array}$ \\
\hline
\end{tabular}

\footnotetext{
${ }^{a}$ Unreliable.

${ }^{b}$ Data not recorded.
} 


\section{Appendix D \\ Airblast Data}

The observed peak overpressures for Project Trinidad are summarized in Tables D1 through D4, together with an analys is of the data. The data have been tabulated in the following format: first, the name of the experiment is given, followed by the charge weight, type of explosive, and depth of burial (DOB, in

Table D1. Close-in airblast observations for Detonations B1 through B8 (single-charges). Altitude $=6200 \mathrm{ft} \mathrm{AMSL;} \mathrm{ambient} \mathrm{pressure} \simeq 810 \mathrm{mbar}$

\begin{tabular}{|c|c|c|c|c|c|c|c|c|}
\hline \multirow[b]{2}{*}{ Detonation } & \multicolumn{5}{|c|}{ Observed data } & \multicolumn{3}{|c|}{$\begin{array}{l}\text { Data scaled } \\
\text { to } 1 \text { ton and } 1000 \mathrm{mbar}\end{array}$} \\
\hline & $\begin{array}{l}\text { Explo- } \\
\text { sive }\end{array}$ & $\begin{array}{l}\mathrm{DOB} \\
\text { (ft) }\end{array}$ & Source & $\begin{array}{l}\text { Distance, } \\
\quad R(f t)\end{array}$ & $\begin{array}{c}\text { Peak } \\
\text { overpressure } \\
\Delta P(\text { psi) }\end{array}$ & $R_{s}\left(\frac{\mathrm{ft}}{\operatorname{ton}^{1 / 3}}\right)$ & $\Delta P_{S}($ mbar $)$ & f \\
\hline \multirow[t]{2}{*}{ B1 (1 ton) } & A NFO & 15.2 & Ground shock & $\begin{array}{r}400 \\
900 \\
2000\end{array}$ & $\begin{array}{l}0.067^{\mathrm{a}} \\
0.021^{\mathrm{a}} \\
0.0088^{\mathrm{a}}\end{array}$ & $\begin{array}{r}373.0 \\
839.0 \\
1864.0\end{array}$ & $\begin{array}{l}5.71^{\mathrm{a}} \\
1.79^{\mathrm{a}} \\
0.75^{\mathrm{a}}\end{array}$ & $\begin{array}{l}0.0776^{\mathrm{a}} \\
0.0643^{\mathrm{a}} \\
0.0703^{\mathrm{a}}\end{array}$ \\
\hline & & & Gas vent & $\begin{array}{r}400 \\
900 \\
2000\end{array}$ & $\begin{array}{l}0.64 \\
0.18 \\
0.076\end{array}$ & $\begin{array}{r}373.0 \\
839.0 \\
1864.0\end{array}$ & $\begin{array}{c}54.6 \\
15.3 \\
6.48\end{array}$ & $\begin{array}{l}0.742 \\
0.550 \\
0.608\end{array}$ \\
\hline \multirow[t]{2}{*}{ B2 (1 ton) } & ANFO & 18.0 & Ground shock & $\begin{array}{r}850 \\
2000\end{array}$ & $\begin{array}{l}0.0072 \\
0.00307\end{array}$ & $\begin{array}{r}792.0 \\
1864.0\end{array}$ & $\begin{array}{l}0.614 \\
0.262\end{array}$ & $\begin{array}{l}0.0206 \\
0.0246\end{array}$ \\
\hline & & & Gas vent & $\begin{array}{r}850 \\
2000\end{array}$ & $\begin{array}{l}0.0119 \\
0.0045\end{array}$ & $\begin{array}{r}792.0 \\
1864.0\end{array}$ & $\begin{array}{l}1.02 \\
0.383\end{array}$ & $\begin{array}{l}0.0342 \\
0.0359\end{array}$ \\
\hline \multirow[t]{2}{*}{ B3 (1 ton) } & $\mathrm{ANFO}$ & 19.7 & Ground shock & $\begin{array}{r}230 \\
720 \\
2020\end{array}$ & $\begin{array}{l}0.041 \\
0.0105 \\
0.00416\end{array}$ & $\begin{array}{r}214.0 \\
672.0 \\
1883.0\end{array}$ & $\begin{array}{l}3.49 \\
0.894 \\
0.355\end{array}$ & $\begin{array}{l}0.0244 \\
0.0246 \\
0.0338\end{array}$ \\
\hline & & & Gas vent & $\begin{array}{r}230 \\
720 \\
2020\end{array}$ & $\begin{array}{l}0.255 \\
0.082 \\
0.0332\end{array}$ & $\begin{array}{r}214.0 \\
672.0 \\
1883.0\end{array}$ & $\begin{array}{r}21.7 \\
6.98 \\
2.83\end{array}$ & $\begin{array}{l}0.151 \\
0.192 \\
0.269\end{array}$ \\
\hline \multirow[t]{2}{*}{ B4 (1 ton) } & T D-2 & 15.9 & Ground shock & $\begin{array}{r}350 \\
1000 \\
2000\end{array}$ & $\begin{array}{l}0.044 \\
0.015 \\
0.0063\end{array}$ & $\begin{array}{r}326.0 \\
932.1 \\
1864.2\end{array}$ & $\begin{array}{l}3.75 \\
1.28 \\
0.537\end{array}$ & $\begin{array}{l}0.0434 \\
0.0523 \\
0.0502\end{array}$ \\
\hline & & & Gas vent & $\begin{array}{r}350 \\
1000 \\
2000\end{array}$ & $\begin{array}{l}0.322 \\
0.101 \\
0.0373\end{array}$ & $\begin{array}{r}326.0 \\
932.1 \\
1864.2\end{array}$ & $\begin{array}{l}27.4 \\
8.61 \\
3.18\end{array}$ & $\begin{array}{l}0.317 \\
0.352 \\
0.298\end{array}$ \\
\hline \multirow[t]{2}{*}{ B5 $(1$ ton $)$} & $\mathrm{TD}-2$ & 18.6 & Ground shock & $\begin{array}{r}295 \\
810 \\
1845\end{array}$ & $\begin{array}{l}0.057 \\
0.021 \\
0.007\end{array}$ & $\begin{array}{r}275.0 \\
755.0 \\
1720.0\end{array}$ & $\begin{array}{l}4.86 \\
1.79 \\
0.596\end{array}$ & $\begin{array}{l}0.0459 \\
0.0568 \\
0.0508\end{array}$ \\
\hline & & & Gas vent & $\begin{array}{r}295 \\
810 \\
1845\end{array}$ & $\begin{array}{l}0.088 \\
0.0335 \\
0.0123\end{array}$ & $\begin{array}{r}275.0 \\
755.0 \\
1720.0\end{array}$ & $\begin{array}{l}7.50 \\
2.85 \\
1.05\end{array}$ & $\begin{array}{l}0.0708 \\
0.0903 \\
0.0896\end{array}$ \\
\hline \multirow[t]{2}{*}{ B6 $(1$ ton $)$} & $\mathrm{TD}-2$ & 20.9 & Ground shock & $\begin{array}{r}163 \\
510 \\
1670\end{array}$ & $\begin{array}{l}0.0705 \\
0.0260 \\
0.0079\end{array}$ & $\begin{array}{r}152.0 \\
475.0 \\
1556.0\end{array}$ & $\begin{array}{l}6.00 \\
2.215 \\
0.673\end{array}$ & $\begin{array}{l}0.0278 \\
0.0403 \\
0.0507\end{array}$ \\
\hline & & & Gas vent & $\begin{array}{r}163 \\
510 \\
1670\end{array}$ & $\begin{array}{l}0.0556 \\
0.0262 \\
0.0064\end{array}$ & $\begin{array}{r}152.0 \\
475.0 \\
1556.0\end{array}$ & $\begin{array}{l}4.74 \\
2.23 \\
0.545\end{array}$ & $\begin{array}{l}0.0220 \\
0.0406 \\
0.0411\end{array}$ \\
\hline \multirow[t]{2}{*}{${ }^{\mathrm{B} 7}$ (1 ton) } & TD-2 & 22.6 & Ground shock & $\begin{array}{r}275 \\
1630\end{array}$ & $\begin{array}{l}0.04 ? \\
0.00446\end{array}$ & $\begin{array}{r}256.0 \\
1520.0\end{array}$ & $\begin{array}{l}3.41 ? \\
0.380\end{array}$ & $\begin{array}{l}0.0294 ? \\
0.0279\end{array}$ \\
\hline & & & Gas vent & $\begin{array}{r}275 \\
1630\end{array}$ & $\begin{array}{l}0.074 \\
0.0149\end{array}$ & $\begin{array}{r}256.0 \\
1520.0\end{array}$ & $\begin{array}{l}6.30 \\
1.27\end{array}$ & $\begin{array}{l}0.0543 \\
0.0933\end{array}$ \\
\hline \multirow[t]{2}{*}{ B8 $(1$ ton $)$} & $\mathrm{TD}-2$ & 28.1 & Ground shock & $\begin{array}{l}140 \\
460 \\
835\end{array}$ & $\begin{array}{l}0.0528 \\
0.0190 \\
0.0070\end{array}$ & $\begin{array}{l}130.5 \\
429.0 \\
778.0\end{array}$ & $\begin{array}{l}4.50 \\
1.62 \\
0.596\end{array}$ & $\begin{array}{l}0.0174 \\
0.0261 \\
0.0195\end{array}$ \\
\hline & & & Gas vent & $\begin{array}{l}140 \\
460 \\
835\end{array}$ & $\begin{array}{l}0.0105 \\
0.0046 \\
0.00133\end{array}$ & $\begin{array}{l}130.5 \\
429.0 \\
778.0\end{array}$ & $\begin{array}{l}0.895 \\
0.392 \\
0.113\end{array}$ & $\begin{array}{l}0.00346 \\
0.00631 \\
0.00371\end{array}$ \\
\hline
\end{tabular}

\footnotetext{
${ }^{a}$ May be a primacord spike rather than the true ground-shock-induced peak overpressure pulse from the detonation.
} 
Table D2a. Close-in airblast observations for Detonations C1 and C2 (row-charges).

Altitude $\simeq 6200 \mathrm{ft}$ AMSL; ambient pressure $\simeq 810 \mathrm{mbar}$

\begin{tabular}{|c|c|c|c|c|c|c|c|}
\hline \multirow[b]{2}{*}{ Detonation } & \multicolumn{4}{|c|}{ Observed data } & \multicolumn{3}{|c|}{$\begin{array}{l}\text { Data scaled } \\
\text { to } 1 \text { ton and } 1000 \mathrm{mbar}\end{array}$} \\
\hline & Source & Azimuth & $\begin{array}{l}\text { Distance, } \\
\quad \mathbf{R}(\mathrm{ft})\end{array}$ & $\begin{array}{c}\text { Peak } \\
\text { overpressure, } \\
\Delta P(\text { psi })\end{array}$ & $R_{s}\left(\frac{\mathrm{ft}}{\operatorname{ton}^{1 / 3}}\right)$ & $\Delta P_{S}($ mbar $)$ & f \\
\hline $\mathrm{C} 1$ & Ground shock & $\perp^{a}$ & $\begin{array}{r}392 \\
1525 \\
3360\end{array}$ & $\begin{array}{l}0.128 \\
0.0134 \\
0.00842\end{array}$ & $\begin{array}{r}365.0 \\
1420.0 \\
3130.0\end{array}$ & $\begin{array}{c}10.90 \\
1.14 \\
0.718\end{array}$ & $\begin{array}{l}0.144 \\
0.077 \\
0.125\end{array}$ \\
\hline \multirow{3}{*}{$\begin{array}{l}\text { (five } 1 \text {-ton } \\
\text { charges of } \\
\text { TD- } 2 \text { buried } \\
\text { at } 18 \mathrm{ft} \text {, } \\
\text { spaced at } \\
32 \mathrm{ft} \text { ) }\end{array}$} & & $n^{b}$ & $\begin{array}{r}302 \\
1000 \\
3171\end{array}$ & $\begin{array}{l}0.093 \\
0.027 \\
-\end{array}$ & $\begin{array}{r}281.0 \\
932.1 \\
2958.0\end{array}$ & $\begin{array}{c}7.92 \\
2.30 \\
-\end{array}$ & $\begin{array}{c}0.0765 \\
0.0941 \\
-\end{array}$ \\
\hline & Gas vent & $\perp$ & $\begin{array}{r}392 \\
1525 \\
3360\end{array}$ & $\begin{array}{l}0.181 \\
0.029 \\
0.0164\end{array}$ & $\begin{array}{r}365.0 \\
1420.0 \\
3130.0\end{array}$ & $\begin{array}{l}15.4 \\
2.48 \\
1.397\end{array}$ & $\begin{array}{l}0.204 \\
0.168 \\
0.244\end{array}$ \\
\hline & & $\|$ & $\begin{array}{r}302 \\
1000 \\
3171\end{array}$ & $\begin{array}{c}0.152 \\
0.051 \\
\end{array}$ & $\begin{array}{r}281.0 \\
932.1 \\
2958.0\end{array}$ & $\begin{array}{r}12.95 \\
4.35 \\
-\end{array}$ & $\begin{array}{c}0.125 \\
0.178 \\
-\end{array}$ \\
\hline $\mathrm{C} 2$ & Ground shock & $\perp$ & $\begin{array}{r}400 \\
1515 \\
3360\end{array}$ & $\begin{array}{l}0.137 \\
0.0131 \\
-\end{array}$ & $\begin{array}{r}373.0 \\
1412.0 \\
3130.0\end{array}$ & $\begin{array}{c}11.67 \\
1.116 \\
-\end{array}$ & $\begin{array}{c}0.159 \\
0.075 \\
-\end{array}$ \\
\hline \multirow{3}{*}{$\begin{array}{l}\text { (five } 1 \text {-ton } \\
\text { charges of } \\
\text { TD-2 buried } \\
\text { at } 20.4 \mathrm{ft}, \\
\text { spaced at } \\
25 \mathrm{ft} \text { ) }\end{array}$} & & $\|$ & $\begin{array}{r}500 \\
1350 \\
2985\end{array}$ & $\begin{array}{l}0.039 \\
\sigma .018 \\
-\end{array}$ & $\begin{array}{r}466.0 \\
1259.0 \\
2780.0\end{array}$ & $\begin{array}{l}3.32 \\
0.852 \\
-\end{array}$ & $\begin{array}{c}0.0592 \\
0.0499 \\
-\end{array}$ \\
\hline & Gas vent & $\perp$ & $\begin{array}{r}400 \\
1515 \\
3360\end{array}$ & $\begin{array}{l}0.093 \\
0.013 \mathrm{~d}\end{array}$ & $\begin{array}{r}373.0 \\
1412.0 \\
3130.0\end{array}$ & $\begin{array}{l}7.92 \\
1.21 \\
-\end{array}$ & $\begin{array}{l}0.108 \\
0.0814 \\
-\end{array}$ \\
\hline & & $\|$ & $\begin{array}{r}500 \\
1350 \\
2985\end{array}$ & $\begin{array}{l}0.039 \\
0.011 e^{5}\end{array}$ & $\begin{array}{r}466.0 \\
1259.0 \\
2780.0\end{array}$ & $\begin{array}{c}3.32 \\
0.98 \\
-\end{array}$ & $\begin{array}{c}0.0592 \\
0.0574 \\
-\end{array}$ \\
\hline
\end{tabular}

\footnotetext{
$a_{\perp}$ - perpendicular to alignment of row.

$b_{\|}$- parallel to and off the end of the row.

$c_{\text {Transmitter drift. }}$

$d_{\text {Record noisy. }}$.

e Record lost.
}

feet). For row-charge events, the row configuration, spacing and delays (if any) between charges in the row, number of charges, and charge weight are also specified. The next column identifies the source of the airblast pulse (groundshock-induced or gas-vent-induced). Next, for row-charge events only, the direction in which the airblast pulse was measured is given [perpendicular to row axis $(1)$ or off the end of the row $(\|)$ ]. The succeeding two columns list the distance $R$ (in feet) from the detonation to a given observed peak overpressure $\Delta P$ (in psi), $\Delta \mathrm{P}$ in this case referring to peak excess above the local ambient pressure. Most of the measured overpressures are average values from two separate gages at the same location. Both the ground-shock and gas-vent peak overpressures are listed (in successive sections of the table) where available. Overpressures for all row-charge detonations were measured in at least two different directions, perpendicular to the row ( $\perp$ to row) and off the end of the row (ll to row). The delayed row-charges have measurements along three directions: perpendicular to the row, of the starting end $\left(\|_{S}\right)$, and off the final end $\left(\|_{F}\right)$ of the 
Table D2b. Close-in airblast observations for Detonations C3 and C4 (row-charges). Altitude $\simeq 6200 \mathrm{ft} \mathrm{AMSL;} \mathrm{ambient} \mathrm{pressure} \simeq 810 \mathrm{mbar}$

\begin{tabular}{|c|c|c|c|c|c|c|c|}
\hline \multirow{2}{*}{ Detonation } & \multicolumn{4}{|c|}{ Observed data } & \multicolumn{3}{|c|}{$\begin{array}{l}\text { Data scaled } \\
\text { to } 1 \text { ton and } 1000 \mathrm{mbar} \\
\end{array}$} \\
\hline & Source & Azimuth & $\begin{array}{l}\text { Distance, } \\
\quad \mathrm{R}(\mathrm{ft})\end{array}$ & $\begin{array}{c}\text { Peak } \\
\text { overpressure, } \\
\Delta P(\text { psi) }\end{array}$ & $\mathrm{R}_{\mathrm{s}}\left(\frac{\mathrm{ft}}{\operatorname{ton}^{1 / 3}}\right)$ & $\Delta P_{S}($ mbar $)$ & f \\
\hline C3 & Ground shock & 1 & $\begin{array}{r}349 \\
1530 \\
3360\end{array}$ & $\begin{array}{l}0.105 \\
0.0175 \\
0.0079\end{array}$ & $\begin{array}{r}325.0 \\
1425.0 \\
3130.0\end{array}$ & $\begin{array}{l}8.94 \\
1.49 \\
0.673\end{array}$ & $\begin{array}{l}0.103 \\
0.101 \\
0.117\end{array}$ \\
\hline \multirow[t]{3}{*}{$\begin{array}{l}\text { (seven } 1 \text {-ton } \\
\text { charges of } \\
\text { TD- } 2 \text { buried } \\
\text { at } 23.5 \mathrm{ft}, \\
\text { spaced at } \\
18 \mathrm{ft} \text { ) }\end{array}$} & & $\|$ & $\begin{array}{l}1160 \\
2791\end{array}$ & $\begin{array}{l}0.0124 / 0.021^{\mathrm{a}} \\
0.0048 / 0.0067^{\mathrm{a}}\end{array}$ & 2600.0 & $\begin{array}{l}1.057 / 1.79^{\mathrm{a}} \\
0.409 / 0.571^{\mathrm{a}}\end{array}$ & $\begin{array}{l}0.0536 / \\
0.0866^{a} \\
0.0516 / \\
0.0873^{a} \\
0.0572 / \\
0.0798^{a}\end{array}$ \\
\hline & Gas vent & 1 & $\begin{array}{r}349 \\
1530 \\
3360\end{array}$ & $\begin{array}{l}0.052 \\
0.0133 \\
0.0049\end{array}$ & $\begin{array}{r}325.0 \\
1425.0 \\
3130.0\end{array}$ & $\begin{array}{l}4.43 \\
1.133 \\
0.418\end{array}$ & $\begin{array}{l}0.051 \\
0.077 \\
0.073\end{array}$ \\
\hline & & $\|$ & $\begin{array}{r}461 \\
1160 \\
2791\end{array}$ & $\begin{array}{l}0.0291 \\
0.0114 \\
0.0045 ?\end{array}$ & $\begin{array}{r}430.0 \\
1080.0 \\
2600.0\end{array}$ & $\begin{array}{l}2.480 \\
0.971 \\
0.383 ?\end{array}$ & $\begin{array}{l}0.040 \\
0.0474 \\
0.0536 ?\end{array}$ \\
\hline $\mathrm{C} 4$ & Ground shock & $\perp$ & $\begin{array}{r}318 \\
1525\end{array}$ & $\begin{array}{l}0.032 \\
0.0052\end{array}$ & $\begin{array}{r}296.0 \\
1420.0\end{array}$ & $\begin{array}{l}2.73 \\
0.443\end{array}$ & $\begin{array}{l}0.0282 \\
0.0299\end{array}$ \\
\hline \multirow{5}{*}{$\begin{array}{l}\text { (five } 1 \text {-ton } \\
\text { charges of } \\
\text { TD-2 buried } \\
\text { at } 20.4 \mathrm{ft}, \\
\text { spaced at } \\
25 \mathrm{ft} \text {, } \\
0.05-\mathrm{sec} \\
\text { delay between } \\
\text { charges) }\end{array}$} & & $\|_{S}^{b}$ & $\begin{array}{r}500 \\
2610\end{array}$ & $\begin{array}{l}0.023 \\
0.0031\end{array}$ & $\begin{array}{r}466.0 \\
2430.0\end{array}$ & $\begin{array}{l}1.96 \\
0.264\end{array}$ & $\begin{array}{l}0.0349 \\
0.0340\end{array}$ \\
\hline & & $\|_{F}^{c}$ & $\begin{array}{l}1005 \\
3000\end{array}$ & 0.010 .7 & $\begin{array}{r}936.5 \\
2800.0\end{array}$ & 0.912 & $\begin{array}{c}0.0375 \\
-\end{array}$ \\
\hline & Gas vent & 1 & $\begin{array}{r}318 \\
1525\end{array}$ & $\begin{array}{l}0.104 \\
0.0212\end{array}$ & $\begin{array}{r}296.0 \\
1420.0\end{array}$ & $\begin{array}{l}8.86 \\
1.806\end{array}$ & $\begin{array}{l}0.0914 \\
0.122\end{array}$ \\
\hline & & $\|_{S}^{b}$ & $\begin{array}{r}500 \\
2610\end{array}$ & $\begin{array}{l}0.0630 \\
0.0129\end{array}$ & $\begin{array}{r}466.0 \\
2430.0\end{array}$ & $\begin{array}{l}5.36 \\
1.10\end{array}$ & $\begin{array}{l}0.0954 \\
0.142\end{array}$ \\
\hline & & $\|_{F}^{c}$ & $\begin{array}{l}1005 \\
3000\end{array}$ & 0.0399 & $\begin{array}{r}936.5 \\
2800.0\end{array}$ & 3.40 & 0.140 \\
\hline
\end{tabular}

\footnotetext{
${ }^{\mathrm{a}}$ Two values given because signal showed double peak.

$\mathbf{b}_{\|_{S}}=$ off end of row at which delay sequence began; i.e., starting end.

$\mathbf{c}_{\|_{F}}=$ off end of row at which delay sequence ended; i.e., final end of two values given because signal showed doubfe peak.

d No signal.
}

row. For the simultaneously detonated Row D1, measurements were made perpendicular to the row uphill $\left({ }^{(}{ }_{U}\right)$, perpendicular to the row downhill $\left(\perp_{D}\right)$, and off one end of the row.

In order to eliminate dependence on charge weight and the effects of local ambient pressure, ranges and overpressures must be scaled to a consistent system. In this instance, all data are scaled to a yield of 1 ton and an ambient pressure of 1,000 mbar. The conversion to scaled points $\left(R_{S}, \Delta P_{S}\right)$ is given by:

$$
\begin{aligned}
& \Delta \mathrm{P}_{\mathrm{S}}=\Delta \mathrm{P} \frac{1000}{\mathrm{P}_{0}} \\
& \mathrm{R}_{\mathrm{S}}=\mathrm{R}\left[\frac{\mathrm{P}_{0}}{1000} \frac{1}{\mathrm{~W}}\right]^{1 / 3},
\end{aligned}
$$

where $P_{0}=$ ambient pressure (mbar) and $\mathrm{W}=$ charge weight (tons). Using $\mathrm{P}_{0}$ $=810$ mbar and $\mathrm{W}=$ total charge weight (or mean individual charge weight for row events), all the observed data points $(R, \Delta P)$ were scaled to $\left(R_{S}, \Delta P_{S}\right)$. The scaled values for each experiment are also compiled in Table D1, with the 
Table D2c. Close-in airblast observations for Detonations C5 and C6 (row-charges). Altitude $\simeq 6200 \mathrm{ft}$ AMSL; ambient pressure $\simeq 810 \mathrm{mbar}$

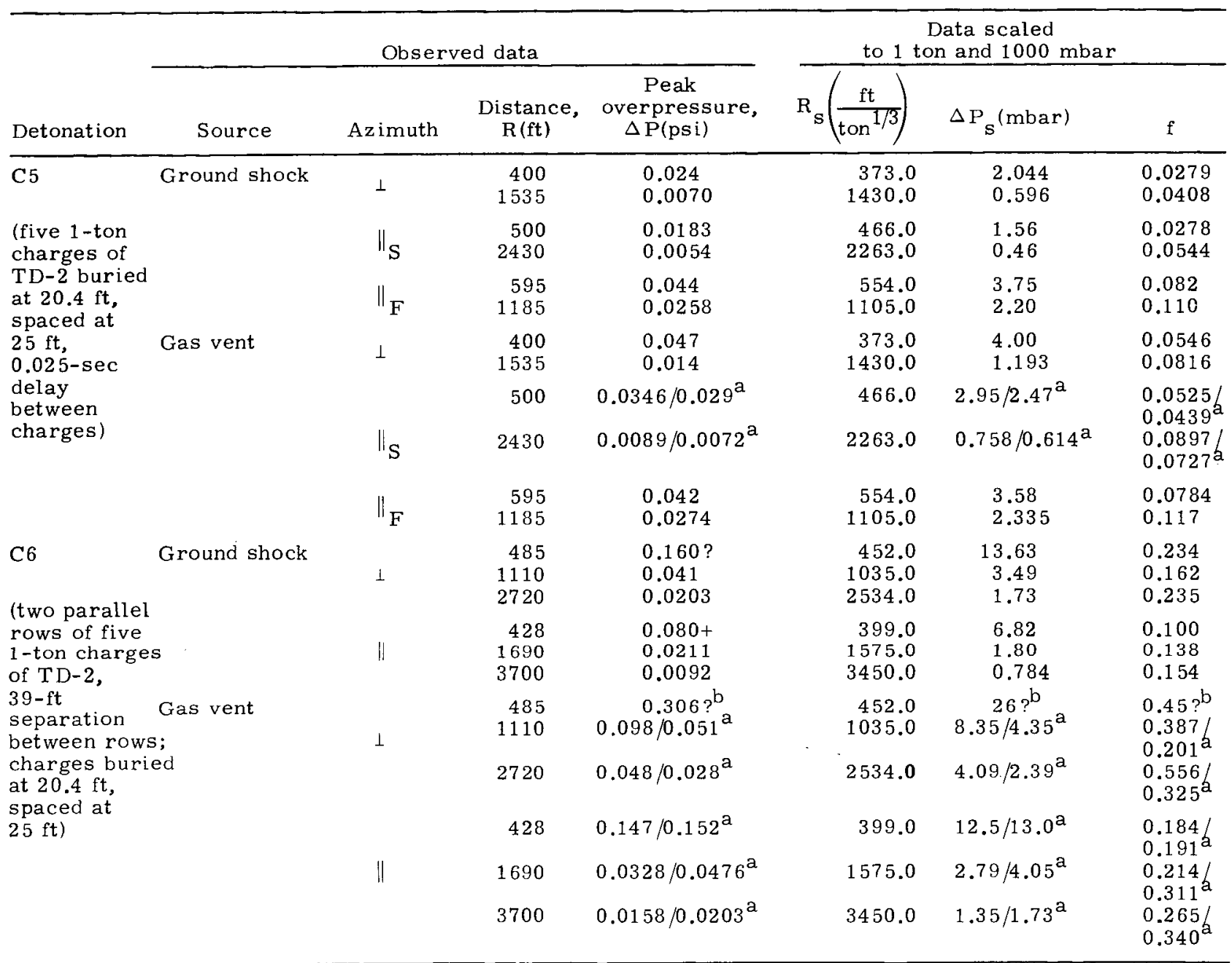

$\mathrm{a}_{\mathrm{T}} \mathrm{T}$ wo values given because signal showed double peak.

${ }^{b}$ Larger of two peaks; calibration unstable, value uncertain.

scaled overpressures $\Delta \mathrm{P}_{\mathrm{S}}$ expressed in $\operatorname{mbar}(1.0 \mathrm{psi}=69 \mathrm{mbar})$.

Using the scaled data, it is possible to compare airblast from experiments with different explosives or at different depths of burial. A convenient means of accomplishing this comparison is the $\mathbf{r}^{-1}$ iting of all airblast data to an arbitrary 5 dard. One useful standard for com$=\cdots n$ is a straight line of slope $R_{S}^{-1.2}$

$$
\begin{aligned}
& \Delta \mathrm{P}_{\mathrm{S}} \text { vs } \mathrm{R}_{\mathrm{S}} \cdot{ }^{22} \text { An } \\
& \text { is chosen through } \\
& \text { /ton }{ }^{1 / 3}, \Delta \mathrm{P}_{\mathrm{S}}
\end{aligned}
$$

$=25.5 \mathrm{mbar})$. All measured overpres sures are related to this standard line by a transmission factor, $f$ :

$f\left(\right.$ at $\left.R_{S}\right)=\frac{\text { Measured } \Delta P_{S}\left(\text { at } R_{S}\right)}{\text { Standard line } \Delta \bar{P}_{S}\left(\text { at } R_{S}\right)}$

Separate values of $f$ are assigned to the phenomenon of ground-shock-induced airblast $\left(f_{g s}\right)$ and the airblast resulting from gas venting ( $f_{\mathrm{gv}}$ ).

The transmission factor will be a function of $R_{S}$, scaled depth of burial, 
Table D3. Close-in airblast observations for Detonations D1 through D3 (row-charges). Altitude $\simeq 6200 \mathrm{ft}$ AMSL; ambient pressure $\simeq 810 \mathrm{mbar}$

\begin{tabular}{|c|c|c|c|c|c|c|c|}
\hline \multirow[b]{2}{*}{ Detonation } & \multicolumn{4}{|c|}{ Observed data } & \multicolumn{3}{|c|}{$\begin{array}{c}\text { Data scaled } \\
\text { to } 1 \text { ton and } 1000 \mathrm{mbar}\end{array}$} \\
\hline & Source & Azimuth & $\begin{array}{l}\text { Distance, } \\
\quad \mathrm{R}(\mathrm{ft})\end{array}$ & $\begin{array}{c}\text { Peak } \\
\text { overpressure, } \\
\Delta P(\text { psi })\end{array}$ & $R_{s}\left(\frac{f t}{\operatorname{ton}^{1 / 3}}\right)$ & $\Delta P_{s}($ mbar $)$ & $f$ \\
\hline \multirow{6}{*}{$\begin{array}{l}\text { D1 } \\
\text { (nine charges } \\
\text { of ANFO, } \\
\text { charge size } \\
200 \text { lb to } \\
2000 \mathrm{lb} \text {, } \\
\text { average } \\
1090 \mathrm{lb} \text {, } \\
\text { mean depth } \\
\text { of burial } \\
23.9 \mathrm{ft} / \mathrm{ton} / 3 \\
\text { mean spacing } \\
15.9 \mathrm{ft} / \mathrm{ton}^{1} / 3\end{array}$} & \multirow{3}{*}{$\begin{array}{l}\text { Ground shock } \\
\text { S }\end{array}$} & ${ }^{1} U^{a}$ & $\begin{array}{r}843 \\
1482\end{array}$ & $\begin{array}{l}0.084 \\
0.0227\end{array}$ & $\begin{array}{r}962.0 \\
1690.0\end{array}$ & $\begin{array}{l}7.16 \\
1.935\end{array}$ & $\begin{array}{l}0.303 \\
0.161\end{array}$ \\
\hline & & ${ }^{\perp}{ }_{D}^{b}$ & $\begin{array}{r}770 \\
1900\end{array}$ & $\begin{array}{l}0.076 \\
0.0128\end{array}$ & $\begin{array}{r}878.0 \\
2170.0\end{array}$ & $\begin{array}{l}6.48 \\
1.09\end{array}$ & $\begin{array}{l}0.246 \\
0.123\end{array}$ \\
\hline & & $\|$ & $\begin{array}{r}700 \\
3280\end{array}$ & $\begin{array}{l}0.0232 \\
0.0048\end{array}$ & $\begin{array}{r}799.0 \\
2740.0\end{array}$ & $\begin{array}{l}1.976 \\
0.409\end{array}$ & $\begin{array}{l}0.0672 \\
0.0886\end{array}$ \\
\hline & Gas vent & ${ }^{\perp} \mathrm{U}$ & $\begin{array}{r}843 \\
1482\end{array}$ & $\begin{array}{l}0.005 \\
0.0013\end{array}$ & $\begin{array}{r}962.0 \\
1690.0\end{array}$ & $\begin{array}{l}0.426 \\
0.111\end{array}$ & $\begin{array}{l}0.0181 \\
0.0093\end{array}$ \\
\hline & \multirow{2}{*}{$e_{j}^{c}$} & ${ }^{\perp} \mathrm{D}$ & $\begin{array}{r}770 \\
1900\end{array}$ & $\begin{array}{l}0.002 \\
0.001\end{array}$ & $\begin{array}{r}878.0 \\
2170.0\end{array}$ & $\begin{array}{l}0.170 \\
0.085\end{array}$ & $\begin{array}{l}0.0065 \\
0.0096\end{array}$ \\
\hline & & $\|$ & $\begin{array}{r}700 \\
3280\end{array}$ & $\begin{array}{l}0.0047 \\
0.0013\end{array}$ & $\begin{array}{r}799.0 \\
3740.0\end{array}$ & $\begin{array}{l}0.401 \\
0.111\end{array}$ & $\begin{array}{l}0.0136 \\
0.0240\end{array}$ \\
\hline \multirow{4}{*}{$\begin{array}{l}\text { D2 } \\
\text { (five } 1 \text {-ton } \\
\text { charges of } \\
\text { TD-1, buried } \\
\text { at } 17.7 \mathrm{ft} \\
\text { spaced at } \\
32 \mathrm{ft} \text { ) }\end{array}$} & \multirow{2}{*}{ Ground shock } & $\perp$ & $\begin{array}{l}1000 \\
3210\end{array}$ & $\begin{array}{l}0.0606 \\
0.0196\end{array}$ & $\begin{array}{r}932.1 \\
2990.0\end{array}$ & $\begin{array}{l}5.16 \\
1.68\end{array}$ & $\begin{array}{l}0.211 \\
0.278\end{array}$ \\
\hline & & $\|$ & $\begin{array}{l}1020 \\
2240 \\
3740\end{array}$ & $\begin{array}{l}0.0460 \\
0.0170 \\
0.0128\end{array}$ & $\begin{array}{r}951.0 \\
2090.0 \\
3490.0\end{array}$ & $\begin{array}{l}3.92 \\
1.45 \\
1.09\end{array}$ & $\begin{array}{l}0.164 \\
0.156 \\
0.217\end{array}$ \\
\hline & \multirow[t]{2}{*}{ Gas vent } & 1 & $\begin{array}{l}1000 \\
3210\end{array}$ & $\begin{array}{l}0.179 \\
0.0411\end{array}$ & $\begin{array}{r}932.1 \\
2990.0\end{array}$ & $\begin{array}{r}15.25 \\
3.50\end{array}$ & $\begin{array}{l}0.624 \\
0.579\end{array}$ \\
\hline & & $\|$ & $\begin{array}{l}1020 \\
2240 \\
3740\end{array}$ & $\begin{array}{l}0.0350 \\
0.0135 \\
0.00884\end{array}$ & $\begin{array}{r}951.0 \\
2090.0 \\
3490.0\end{array}$ & $\begin{array}{l}2.98 \\
1.15 \\
0.753\end{array}$ & $\begin{array}{l}0.125 \\
0.124 \\
0.150\end{array}$ \\
\hline \multirow{4}{*}{$\begin{array}{l}\text { D3 } \\
\text { (two-paral- } \\
\text { lel rows, } \\
\text { each six } \\
\text { charges of } \\
\text { IR10; down- } \\
\text { hill row: } 1- \\
\text { ton charges } \\
\text { buried at } \\
19.1 \mathrm{ft} \text {, space } \\
\text { at } 35 \mathrm{ft} \text { ) }\end{array}$} & \multirow{2}{*}{$\begin{array}{l}\text { Ground shock } \\
\text { (1-ton row) }\end{array}$} & $\perp$ & $\begin{array}{l}1000 \\
3210\end{array}$ & $\begin{array}{l}0.05 \\
0.0156\end{array}$ & $\begin{array}{r}932.1 \\
2990.0\end{array}$ & $\begin{array}{l}4.26 \\
1.33\end{array}$ & $\begin{array}{l}0.174 \\
0.220\end{array}$ \\
\hline & & $\|$ & $\begin{array}{r}720 \\
2220 \\
3815\end{array}$ & $\begin{array}{l}0.0195 \\
0.0067 \\
0.00328\end{array}$ & $\begin{array}{r}671.0 \\
2070.0 \\
3555.0\end{array}$ & $\begin{array}{l}1.66 \\
0.571 \\
0.279\end{array}$ & $\begin{array}{l}0.046 \\
0.061 \\
0.057\end{array}$ \\
\hline & \multirow{2}{*}{$\begin{array}{l}\text { Gas vent } \\
\text { (1-ton row) } \\
\text { ed }\end{array}$} & 1 & $\begin{array}{l}1000 \\
3210\end{array}$ & $\begin{array}{l}0.0653 \\
0.0210\end{array}$ & $\begin{array}{r}932.1 \\
2990.0\end{array}$ & $\begin{array}{l}5.56 \\
1.79\end{array}$ & $\begin{array}{l}0.228 \\
0.296\end{array}$ \\
\hline & & $\|$ & $\begin{array}{r}720 \\
2220 \\
3815\end{array}$ & $\begin{array}{l}0.0526 \\
0.0185 \\
0.0088\end{array}$ & $\begin{array}{r}671.0 \\
2070.0 \\
3555.0\end{array}$ & $\begin{array}{l}4.48 \\
1.576 \\
0.750\end{array}$ & $\begin{array}{l}0.123 \\
0.168 \\
0.153\end{array}$ \\
\hline \multirow{4}{*}{$\begin{array}{l}\text { (uphill row: } \\
2 \text {-ton } \\
\text { charges } \\
\text { buried at } \\
24.4 \mathrm{ft}, \\
\text { spaced at } \\
35 \mathrm{ft} \text {, } \\
40-\mathrm{ft} \text { separa- } \\
\text { tion and } \\
0.25-\mathrm{sec} \\
\text { delay between } \\
\text { the two rows) }\end{array}$} & \multirow{2}{*}{$\begin{array}{l}\text { Ground shock } \\
\text { (2-ton row) }\end{array}$} & $\perp$ & $\begin{array}{l}1000 \\
3210\end{array}$ & $\underline{-}^{\mathrm{d}}$ & $\begin{array}{r}740.0 \\
2375.0\end{array}$ & $\underline{-}^{d}$ & $-^{d}$ \\
\hline & & $\|$ & $\begin{array}{r}720 \\
2220 \\
3815\end{array}$ & $\begin{array}{l}0.0441 \\
0.186 \\
0.00938\end{array}$ & $\begin{array}{r}533.0 \\
1643.0 \\
2820.0\end{array}$ & $\begin{array}{l}3.76 \\
1.585 \\
0.799\end{array}$ & $\begin{array}{l}0.0785 \\
0.128 \\
0.123\end{array}$ \\
\hline & \multirow{2}{*}{$\begin{array}{l}\text { Gas vent } \\
\text { (2-ton row) }\end{array}$} & 1 & $\begin{array}{l}1000 \\
3210\end{array}$ & $\begin{array}{l}0.0579 \\
0.0235\end{array}$ & $\begin{array}{r}740.0 \\
2375.0\end{array}$ & $\begin{array}{l}4.93 \\
2.00\end{array}$ & $\begin{array}{l}0.153 \\
0.251\end{array}$ \\
\hline & & $\|$ & $\begin{array}{r}720 \\
2220 \\
3815\end{array}$ & $\begin{array}{l}0.0498 \\
0.0203 \\
0.01035\end{array}$ & $\begin{array}{r}533.0 \\
1643.0 \\
2820.0\end{array}$ & $\begin{array}{l}4.24 \\
1.73 \\
0.882\end{array}$ & $\begin{array}{l}0.0885 \\
0.139 \\
0.136\end{array}$ \\
\hline
\end{tabular}

\footnotetext{
${ }^{\mathrm{a}_{\perp}}$ - perpendicular to row, uphill side.
}

$\mathrm{b}_{\perp}$ - perpendicular to row, downhill side.

${ }^{c}$ Weighted by individual charge yields to overemphasize the larger charges; this weighting has almost no effect on the data reduction. Weighting not normally used in prediction procedures.

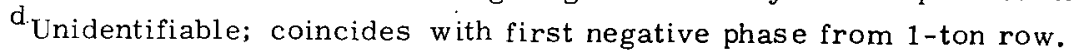


Table D4. Close-in airblast observations for Detonation D4 (row-charges).

\begin{tabular}{|c|c|c|c|c|c|c|}
\hline \multirow[b]{2}{*}{ Detonation } & \multicolumn{4}{|c|}{ Observed data } & \multicolumn{2}{|c|}{$\begin{array}{c}\text { Data scaled } \\
\text { to } 1 \text { ton and } 1000 \mathrm{mbar} \\
\end{array}$} \\
\hline & Source & Azimuth & $\begin{array}{c}\text { Distance, } \\
\mathrm{R}(\mathrm{ft})\end{array}$ & $\begin{array}{c}\text { Peak } \\
\text { overpressure, } \\
\Delta \mathrm{P}(\mathrm{ps} \mathrm{i})\end{array}$ & $\mathrm{R}_{\mathrm{s}}\left(\frac{\mathrm{ft}}{\operatorname{ton}^{1 / 3}}\right)$ & $\mathrm{P}_{\mathrm{s}}(\mathrm{mbar})$ \\
\hline \multirow[t]{10}{*}{$D 4^{\mathrm{a}}$} & $\begin{array}{l}\text { Ground shock } \\
(1 \text {-ton row) }\end{array}$ & $1^{b}$ & $\begin{array}{r}775 \\
2,168 \\
1,060\end{array}$ & $\begin{array}{l}0.140 \\
0.097 \\
0.097\end{array}$ & $\begin{array}{r}722 \\
2020 \\
988\end{array}$ & $\begin{array}{r}11.9 \\
8.25 \\
8.24\end{array}$ \\
\hline & & $\|$ & $\begin{array}{r}560 \\
3,800 \\
11,750\end{array}$ & $\begin{array}{l}0.106^{\mathrm{c}} \\
0.0049 \\
0.00196\end{array}$ & $\begin{array}{r}522 \\
3540 \\
10950\end{array}$ & $\begin{array}{l}9.04 \\
0.417 \\
0.167\end{array}$ \\
\hline & $\begin{array}{l}\text { Gas vent } \\
(1-\text { ton row })\end{array}$ & $\perp^{b}$ & $\begin{array}{r}775 \\
2,168 \\
1,060\end{array}$ & $\begin{array}{l}0.123^{\mathrm{d}} \\
0.0616^{\mathrm{d}} \\
-\end{array}$ & $\begin{array}{r}722 \\
2020 \\
988\end{array}$ & $\begin{array}{c}10.5 \\
5.25 \\
-\mathrm{e}\end{array}$ \\
\hline & & $\|$ & $\begin{array}{r}560 \\
3,800 \\
11,750\end{array}$ & $\begin{array}{l}0.114^{c} \\
0.0115^{c} \\
0.00429\end{array}$ & $\begin{array}{r}522 \\
3540 \\
10950\end{array}$ & $\begin{array}{l}9.7 \\
0.98 \\
0.365\end{array}$ \\
\hline & $\begin{array}{l}\text { Ground shock } \\
\text { (2-ton row) }\end{array}$ & $\perp^{b}$ & $\begin{array}{r}775 \\
2,168 \\
1,060\end{array}$ & $\begin{array}{l}0.123^{\mathrm{d}} \\
0.0616^{\mathrm{d}} \\
0.139\end{array}$ & $\begin{array}{r}587 \\
1643 \\
803\end{array}$ & $\begin{array}{l}10.5 \\
525 \\
11.8\end{array}$ \\
\hline & $\begin{array}{l}\text { Gas vent } \\
(2-\text { ton row })\end{array}$ & $\perp^{b}$ & $\begin{array}{r}775 \\
2,168 \\
1.060\end{array}$ & $\begin{array}{l}0.169 \\
0.131 \\
0.336\end{array}$ & $\begin{array}{c}587 \\
1643 \\
803\end{array}$ & $\begin{array}{l}14.4 \\
1.1 .2 \\
28.6^{\mathrm{e}}\end{array}$ \\
\hline & $\begin{array}{l}\text { Unidentified } \\
3 \text { rd peak }\end{array}$ & & $\begin{array}{r}560 \\
3,800 \\
11,750\end{array}$ & $\begin{array}{l}0.143^{C} \\
0.0088 \\
0.00361\end{array}$ & - & I \\
\hline & 4 th peak ${ }^{f}$ & & $\begin{array}{r}560 \\
3,800 \\
11,750\end{array}$ & $\begin{array}{l}0.060^{\mathrm{c}} \\
0.0085^{\mathrm{c}} \\
0.00315\end{array}$ & E & z \\
\hline & 5 th peak ${ }^{f}$ & $\|$ & $\begin{array}{r}560 \\
3,800 \\
11,750\end{array}$ & $\begin{array}{l}0.124^{\mathrm{C}} \\
0.0187 \\
0.00795\end{array}$ & z & E \\
\hline & 6 th peak ${ }^{f}$ & & $\begin{array}{r}560 \\
3,800 \\
11,750\end{array}$ & $\begin{array}{l}0.115^{\mathrm{C}} \\
0.0232^{\mathrm{c}} \\
0.0101\end{array}$ & 二 & $\bar{z}$ \\
\hline
\end{tabular}

${ }^{\mathrm{a}}$ The $\mathrm{D} 4$ detonation was a double row of charges, emplaced along the contour of a gentle slope. The downhill row (1-ton row) consisted of 18 charges, each of 1 -ton yield. The uphill row (2-ton row) consisted of 14 charges, 12 of 2 -ton and 2 of 1 -ton yield. The spacing between rows was $46 \mathrm{ft}$ (approximately $41 \mathrm{ft} / \operatorname{ton}^{1 / 3}$ ). The 1 -ton row was detonated approximately $150 \mathrm{msec}$ before the 2-ton row.
Mean yield of 1 -ton row
Total yield of 1 -ton row
Mean DOBg of 1 -ton row
$=1.0$ ton
$=19.7 \mathrm{ft} / \mathrm{ton} 1 / 3$
$\begin{aligned} \text { Total yield of } 2 \text {-ton row } & =1.86 \text { ton } \\ \text { Tot } & =26.0 \text { tons }\end{aligned}$
Mean DOB of 2 -ton row $\quad=17.9 \mathrm{ft} / \mathrm{ton} 1 / 3$
Mean spacing of 2 -ton row $\quad=28.5 \mathrm{ft} / \mathrm{ton}^{1 / 3}$

${ }^{b}$ Perpendicular overpressures include values measured along both perpendiculars (closer to the 1 -ton row, and closer to the 2 -ton row). The measured values at a given range along. these two directions differ by about $30 \%$ in some cases, due to partial and variable overlap between pulses contributed by the two rows. The various contributions are usually inseparable and precise reinforcement factors cannot be determined.

${ }^{c}$ Adjusted values - overpressure or pulse identification may be uncertain.

${ }^{d}$ Gas-vent pulse for 1 -ton row overlaps ground-shock pulse for 2-ton row in this direction.

${ }^{e}$ Gas-vent pulses for both rows coincide at this station; scaled values are scaled on the basis of "2-ton row" alone.

f The waveforms of the pulses observed off the end of the rows were complex, consisting of multiple peaks whose relative amplitudes and attenuation rates varied significantly. Six distinct peaks were observed; the third, fourth, fifth, and sixth peaks could not be assigned to any specific source, due to the great length and the time delay of the two rows with resultart overlap and variable reinforcement between various pulses. The fifth and sixth peaks were apparently dominant at all ranges off the end of the rows. No scaled distances or reinforcment factors could be determined due to the fact that the sources of the dominant pulses are not always identifiable.

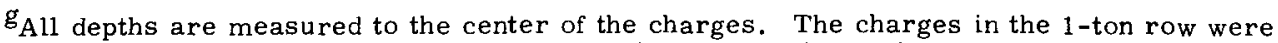
emplaced in underreamed holes, and had a height-to-diameter ratio of about 1.0. The holes for the 2-ton row were not underreamed, and the charges had a height-to-diameter ratio of about 4 to 1 . These charges were approximately $10 \mathrm{ft}$ long. Thus, the upper portions of the 2 -ton charges were quite close to the ground surface, and these charges probably vented at rather early time (causing high gas-vent overpressures from the 2-ton row). 
medium, and explosive type (for singlecharge detonations). Close and intermediate range peak overpressures for most cratering experiments attenuate with distance approximately as $\mathrm{R}_{\mathrm{S}}^{-1.2}$. The largest transmission factor observed for a given experiment will thus provide an indication of the maximum expected damage-producing airblast from any experiment at the same scaled burial depth with the same explosive in the same medium.

Calculated transmission factors for all buried Trinidad experiments are listed in the last column of Tables D1 through D4. These values will be used to compare the various experiments.

\section{SINGLE-CHARGE BURIED EVENTS}

The most consistent airblast results are generally obtained from single-charge events. Therefore, it is of interest to examine Detonations B1 through B8. The three ammonium nitrate fuel oil (ANFO) events, B1, B2, and B3, show considerable scatter. Values of $\mathrm{f}_{\mathrm{gs}}$ are comparable to the other single-charge events, although B2 and B3 appear rather low. Values of $\mathrm{f}_{\mathrm{gv}}$ for $\mathrm{B} 1$ and $\mathrm{B} 3$ are higher than for any of the other (aluminized slurry) experiments, but those for B2 are lower. B2 was intermediate between B1 and $\mathrm{B} 3$ in scaled depth. The erratic behavior of the gas-vent airblast from ANFO detonations is believed to be a result of erratic vent times that are not closely correlated with scaled depth of burial. 16

The aluminized ammonium-nitrate slurry events show more consistent behavior. Values of $f$ for ground-shock
( $f_{g s}$ ) and gas-vent ( $f_{g v}$ ) are plotted as a function of scaled depth of burial in

Fig. D1. In this case, $\mathrm{f}_{\mathrm{gs}}$ decreases slowly with increasing scaled depth of burial, as expected. A straight line is fitted through the maximum values of $f_{\text {gs }}$, which are approximately $t$ wice those observed for TNT experiments at comparable scaled depths. Values of $\mathrm{f}_{\mathrm{gv}}$ show more deviation, indicating that some scatter of the vent times occurs for these experiments as well. However, $\mathrm{f}_{\mathrm{gv}}$ does decrease sharply with increasing depth, as it should. The plotted values of $f_{g v}$ are greater than those observed for TNT events at comparable scaled depths by a factor of two to ten. Two curves are drawn through the maximum values of $\mathrm{f}_{\mathrm{gv}}$; the lower curve is considered the best estimate of the maximum gas-vent transmission factors for typical events.

\section{ROW-CHARGE EVENTS}

Airblast from a row of equal-size charges at a given scaled depth is greater than the airblast that would be produced by only one of the charges detonated at the same scaled depth. The reinforcement of airblast for row-charge events is usually measured by the ratio of the peak overpressure (or value of f), at a given distance from the row, to the peak overpressure (or value of $f$ ) at the same distance from a single charge of the same weight as the average weight of the charges in the row and at the same average scaled depth of burial. This ratio is known as the "difference iactor" between row and single charge airblast.

The difference factors for past experiments under partially controlled 


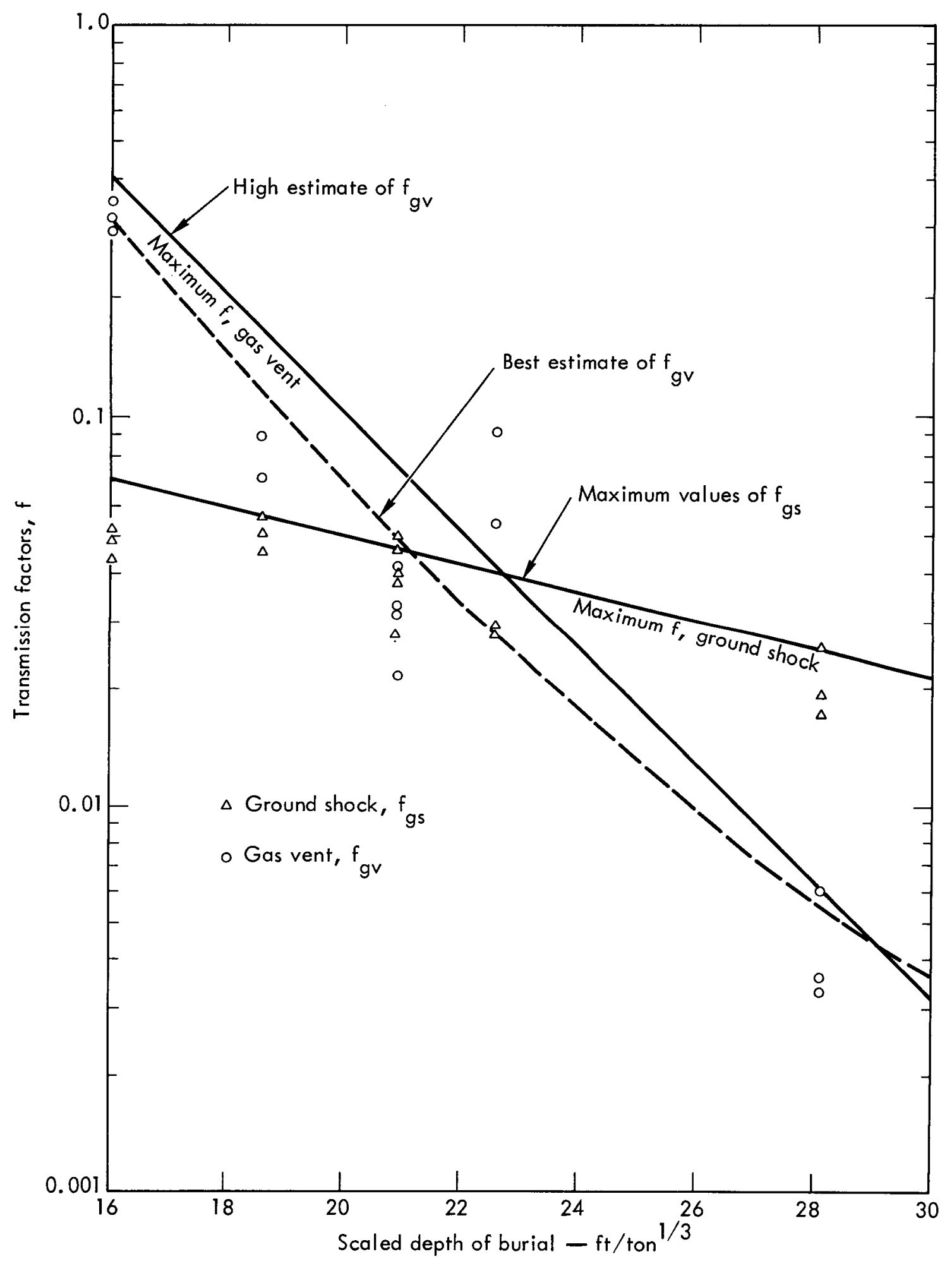

Fig. D1. Observed single-charge transmission factors as a function of scaled depth of burst for aluminized ammonium nitrate slurry detonations, Project Trinidad. 
conditions have been found to fit a law of the form:

$$
\text { Difference factor }=n^{B}
$$

where $\mathbf{n}=$ number of charges in the row and $\mathrm{B}=$ an exponent whose value depends upon the following:

- The azimuth, relative to the alignment of the row, at which the airblast is observed. " $\mathrm{B}$ " will be a maximum for observations perpendicular to the row, and will decrease at azimuths closer to the row axis.
- The scaled depth of burial.

- The scaled spacing between charges.

- The rock type

- The type of explosive

- The average charge weight

- The absolute length of the row

- The scaled range at which the airblast is observed.

Difference factors and values of $B$ have been calculated for the Trinidad row experiments. First, the average charge weight and the average scaled depth of burial for each row were determined (Table D1). The observed overpressures

Table D5a. Ground-shock-induced overpressure reinforcement correction factors for Trinidad row-charge detonations.

$\Delta P($ row charge $)=n^{B} \Delta P($ single charge at same scaled range $)$

\begin{tabular}{|c|c|c|c|c|}
\hline \multirow[b]{2}{*}{ Detonation } & \multirow[b]{2}{*}{ Direction } & \multicolumn{3}{|c|}{ Difference } \\
\hline & & $\mathrm{n}$ & factor, $n^{B}$ & B \\
\hline $\mathrm{C} 1$ & $\begin{array}{l}\text { Perpendicular to row } \\
\text { Parallel to row }\end{array}$ & 5 & $\begin{array}{l}2.44 \\
1.60\end{array}$ & $\begin{array}{l}0.554 \\
0.292\end{array}$ \\
\hline $\mathrm{C} 2$ & $\begin{array}{l}\text { Perpendicular to row } \\
\text { Parallel to row }\end{array}$ & 5 & $\begin{array}{l}3.31 \\
1.23\end{array}$ & $\begin{array}{l}0.744 \\
0.128\end{array}$ \\
\hline C3 & $\begin{array}{l}\text { Perpendicular to row } \\
\text { Parallel to row }\end{array}$ & 7 & $\begin{array}{l}3.08 \\
2.30,1.51^{\mathrm{a}}\end{array}$ & $\begin{array}{l}0.578 \\
0.428,0.212^{\mathrm{a}}\end{array}$ \\
\hline $\begin{array}{c}\mathrm{C4} \\
(\text { delay }= \\
0.05 \mathrm{sec})\end{array}$ & $\begin{array}{l}\text { Perpendicular to row } \\
\text { Parallel to starting end } \\
\text { Parallel to final end }\end{array}$ & 5 & $\begin{array}{l}(0.622)^{\mathrm{b}} \\
(0.727) \\
(0.781)\end{array}$ & $\begin{array}{l}<0 \\
<0 \\
<0\end{array}$ \\
\hline $\begin{array}{l}\text { C5 } \\
(\text { delay = } \\
0.025 \mathrm{sec})\end{array}$ & $\begin{array}{l}\text { Perpendicular to row } \\
\text { Parallel to starting end } \\
\text { Parallel to final end }\end{array}$ & 5 & $\begin{array}{l}(0.850)^{\mathrm{b}} \\
1.13 \\
2.29\end{array}$ & $\begin{array}{l}<0 \\
0.076 \\
0.515\end{array}$ \\
\hline C6 & $\begin{array}{l}\text { Perpendicular to row } \\
\text { Parallel to row }\end{array}$ & $10^{c}$ & $\begin{array}{l}4.90 \\
3.21\end{array}$ & $\begin{array}{l}0.690 \\
0.506\end{array}$ \\
\hline D1 & $\begin{array}{l}\text { Perpendicular to row, uphill } \\
\text { Perpendicular to row, downhill } \\
\text { Parallel to row }\end{array}$ & 9 & $\begin{array}{l}8.42 \\
6.83 \\
2.46\end{array}$ & $\begin{array}{l}0.97 \\
0.874 \\
0.41\end{array}$ \\
\hline D2 & $\begin{array}{l}\text { Perpendicular to row } \\
\text { Parallel to row }\end{array}$ & 5 & $\begin{array}{l}4.55 \\
3.56\end{array}$ & $\begin{array}{l}0.940 \\
0.789\end{array}$ \\
\hline \multirow[t]{2}{*}{ D3 } & $\begin{array}{l}\text { Perpendicular to } 1 \text {-ton row } \\
\text { Parallel to } 1 \text {-ton row }\end{array}$ & of 1 ton & $\begin{array}{l}4.07 \\
1.13\end{array}$ & $\begin{array}{l}0.784 \\
0.068\end{array}$ \\
\hline & $\begin{array}{l}\text { Perpendicular to } 2 \text {-ton row } \\
\text { Parallel to } 2 \text {-ton row }\end{array}$ & of $2^{6}$ tons & $2 \overline{42}$ & $0 . \overline{493}$ \\
\hline
\end{tabular}

\footnotetext{
${ }^{a}$ Two values given because signal showed double peak; larger value listed first.

${ }^{b}$ Values in parentheses indicate airblast overpressures less than comparable fitted single-charge values; considered somewhat questionable.

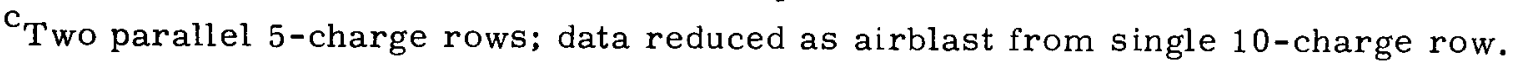


and distances were then scaled according to the average charge weight, and values of $f$ were calculated. The largest observed value of $f$ in each direction for each experiment was compared to the value of $f$ for a single-charge experiment at the same scaled depth of burial (see Fig. D1), and the difference factor was calculated: difference factor $=\mathrm{f}$ rowcharge/f single charge for the same scaled depth. The ground-shock line in
Fig. D1 was used to obtain the value of $f_{\text {gs }}$ for a single charge, and the lower of the two curves through the gas-vent values was used to obtain $\mathrm{f}_{\mathrm{gv}}$ for a single charge. The calculated difference factors are listed in Table D5a (ground-shock observations) and Table D5b (gas vent observations).

Because the number of charges for each experiment is known, the value of $B$ can be calculated. The B-values are

Table D5b. Gas-vent-induced overpressure reinforcement correction factors for Trinidad row-charge detonations.

$\Delta P($ row charge $)=n^{B} \Delta P($ single charge at same scaled range $)$

\begin{tabular}{|c|c|c|c|c|}
\hline Detonation & Direction & $\mathrm{n}$ & $\begin{array}{l}\text { Difference } \\
\text { factor, } n^{B}\end{array}$ & B \\
\hline $\mathrm{C} 1$ & $\begin{array}{l}\text { Perpendicular to row } \\
\text { Parallel to row }\end{array}$ & 5 & $\begin{array}{l}1.63 \\
1.19\end{array}$ & $\begin{array}{l}0.304 \\
0.108\end{array}$ \\
\hline $\mathrm{C} 2$ & $\begin{array}{l}\text { Perpendicular to row } \\
\text { Parallel to row }\end{array}$ & 5 & $\begin{array}{l}1.80 \\
(1.0)^{\mathrm{a}}\end{array}$ & $\begin{array}{c}0.365 \\
(0)\end{array}$ \\
\hline $\mathrm{C} 3$ & $\begin{array}{l}\text { Perpendicular to row } \\
\text { Parallel to row }\end{array}$ & 7 & $\begin{array}{l}3.50 \\
2.16,2.44^{b}\end{array}$ & $\begin{array}{l}0.644 \\
0.396,0.459^{b}\end{array}$ \\
\hline $\begin{array}{c}\mathrm{C4} \\
(\text { delay }= \\
0.05 \mathrm{sec})\end{array}$ & $\begin{array}{l}\text { Perpendicular to row } \\
\text { Parallel to starting end } \\
\text { Parallel to final end }\end{array}$ & 5 & $\begin{array}{l}2.03 \\
2.37 \\
2.33\end{array}$ & $\begin{array}{l}0.44^{c} \\
0.536 \\
0.526\end{array}$ \\
\hline $\begin{array}{l}\text { C5 } \\
(\text { delay }= \\
0.025 \mathrm{sec})\end{array}$ & $\begin{array}{l}\text { Perpendicular to row } \\
\text { Parallel to starting end } \\
\text { Parallel to final end }\end{array}$ & 5 & $\begin{array}{l}1.36 \\
1.50,1.21 \mathrm{~d} \\
1.95\end{array}$ & $\begin{array}{l}0.191 \\
0.252,0.117^{\mathrm{d}} \\
0.415\end{array}$ \\
\hline $\mathrm{C} 6$ & $\begin{array}{l}\text { Perpendicular to row } \\
\text { Parallel to row }\end{array}$ & $10^{\mathrm{e}}$ & $\begin{array}{l}9.26,5.42^{\mathrm{d}} \\
5.66,4.42\end{array}$ & $\begin{array}{l}0.966,0.734^{\mathrm{d}} \\
0.753,0.645\end{array}$ \\
\hline D1 & $\begin{array}{l}\text { Perpendicular to row, uphill } \\
\text { Perpendicular to row, downhill } \\
\text { Paratlel to row }\end{array}$ & 9 & $\begin{array}{l}(1.0) \\
(0.505) \\
1.26\end{array}$ & $\begin{array}{c}(0) \\
<0 \\
0.105\end{array}$ \\
\hline D2 & $\begin{array}{l}\text { Perpendicular to row } \\
\text { Parallel to row }\end{array}$ & 5 & $\begin{array}{c}3.67 \\
(0.88)\end{array}$ & $\begin{array}{c}0.808 \\
<0\end{array}$ \\
\hline \multirow[t]{2}{*}{ D3 } & $\begin{array}{l}\text { Perpendicular to } 1 \text {-ton row } \\
\text { Parallel to } 1 \text {-ton row }\end{array}$ & $\begin{array}{c}6 \\
\text { of } 1 \text { ton }\end{array}$ & $\begin{array}{l}3.05 \\
1.73\end{array}$ & $\begin{array}{l}0.622 \\
0.306\end{array}$ \\
\hline & $\begin{array}{l}\text { Perpendicular to } 2 \text {-ton row } \\
\text { Parallel to } 2 \text {-ton row }\end{array}$ & $\begin{array}{c}6 \\
\text { of } 2 \text { tons }\end{array}$ & $\begin{array}{l}2.92 \\
1.62\end{array}$ & $\begin{array}{l}0.598 \\
0.269\end{array}$ \\
\hline
\end{tabular}

\footnotetext{
${ }^{a}$ Values in parentheses indicate airblast overpressures less than comparable fitted single-charge values; considered somewhat questionable.

${ }^{b}$ Larger of two listed values derives from questionable airblast measurement.

${ }^{C_{Q}}$ Questionable because of the very rapid attenuation of gas-vent overpressures with distance perpendicular to the $\mathrm{C} 4$ row.

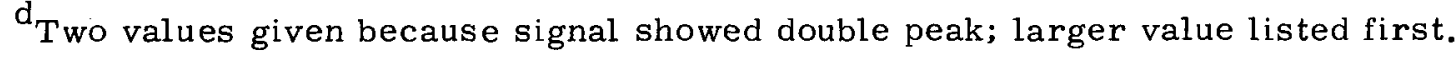

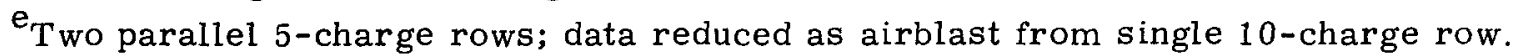


listed in the last column of Tables D5a and D5b.

Experiment D3 consisted of two sixcharge rows, but the separation and time delay between the rows were sufficiently great that almost no airblast interaction . or reinforcement occurred; therefore, the pulses from each row were treated as if they originated from two separate sixcharge rows and were analyzed separately. The C6 double row, on the other hand, had no interrow delay. Separate signals from the two rows could not be identified, and the event was treated as a single tencharge row (rather than two five-charge rows).

It should be noted that, except for D1, all rows consisted of aluminized ammoniumnitrate slurry charges in rock very similar to that of the B-series tests. Therefore, the comparison of singlecharge values of $f$ from Fig. D1 to $f$ values for the row-charge events should be valid. Experiment D1 used ANFO and may show the erratic gas venting behavior noted for the single charge ANFO experiments. The value of $f_{g v}$ for D-1 did indeed turn out to be very low (Table D5b), being comparable to that expected for a single-charge $(B \approx 0)$.

The B-values in Tables D5a and D5b show an enormous amount of scatter, varying all the way from $B=0$ (singlecharge airblast) to $B \approx 1.0$ (perfect acoustic reinforcement). The average values tend to be somewhat greater (more reinforcement) than those previously determined for relatively large-yield rows (charge weights $\approx 10$ tons), but less than the observed reinforcement for small-yield rows (charge weights $\approx 64 \mathrm{lb}$ ). ${ }^{22}$ No definite correlation could be established with scaled depth of burial, number of charges in the row, or scaled spacing between charges. ${ }^{22}$ The reasons for this erratic behavior are not fully understood, but are believed to be related to the inhomogeneous nature of the medium, relatively small charge weights, and irregular venting behavior. Many of the experiments showed highly complex waveforms in which some peaks could not be positively identified or interpreted. Irregular and unexplained variations in vent times between the individual charges in a row may have contributed to the scatter in the data. The ground-shockinduced pulses showed complex multiple peaks for some experiments. It is impossible to establish completely consistent relationships between single-and rowcharge airblast similar to those found for experiments in more uniform media. However, best estimates of the rowcharge difference factors are given in Table D6. The conclusions discussed below must be considered tentative at best. A more extensive discussion of the observed overpressures and attenuation rates for individual row-charge events is given in Ref. 16.

Waveforms observed off-the-end-of and perpendicular to the $D 4$ (RR1) double row were of extraordinary complexity. The length of the rows and the interrow delay, as well as the inconsistent venting behavior from charge to charge within a row, caused various pulses to overlap and reinforce in a complex manner dependent on azimuth and range. Overlap rendered the source of some peaks unidentifiable, particularly of the end of the rows. For these reasons, scaling of the overpressures and determination of 
Table D6. Airblast amplitudes for row-charges expressed in terms of single-charge airblast amplitudes.

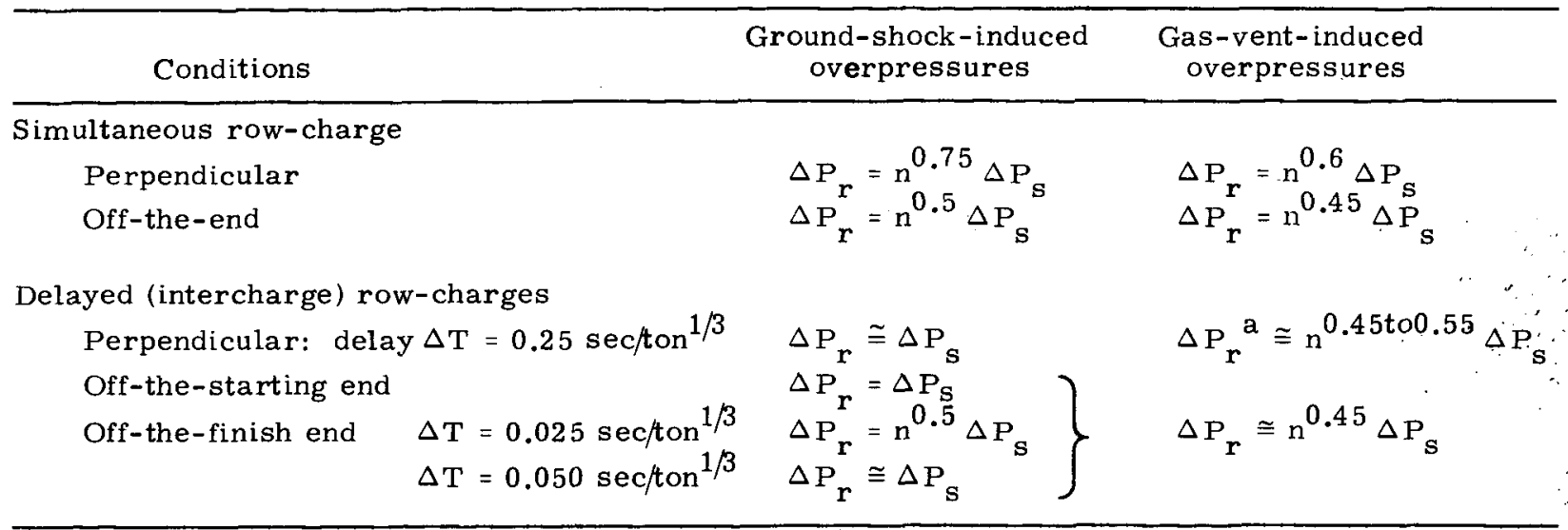

\footnotetext{
${ }^{a}$ Estimate based on very limited data.
}

the reinforcement factors cannot be accurately accomplished. It is hoped that this situation will improve when more data from long rows become available. Meanwhile, the D4 data cannot be included in the "reinforcement factor" analysis, and we can only predict approximate "maximum" expected reinforcement factors for very long or complex rows based on the particular case in question.

Other problems with the D4 measurements include inconsistent attenuation rates in a given direction (related to the problems mentioned above), and some questionable data points as noted in the table. $^{16}$

The principal characteristic of the airblast data for row-charges is the large amount of scatter. However, the observed difference factors (i.e., airblast reinforcement) for all experiments in this series have a fairly well-defined upper bound for each component of the airblast pulse (gas vent and ground shock). These estimated upper limits, as listed in Table D6, may be used to predict reliably the airblast amplitudes for similar experi- ments. Estimates of the difference factors presented in Table D6 should apply most accurately for detonations similar to those at Trinidad; i.e., five to ten charge rows, charge weights from 0.5 to 2 tons, nearoptimum intercharge spacing (16 to $35 \mathrm{ft} /$ ton $\left.^{1 / 3}\right)$, and aluminized ammoniumnitrate slurry explosive in weak rock. These difference factors apply either to the peak single-charge overpressures $\Delta \mathrm{P}_{\mathrm{S}}$ at intermediate ranges, or to the maximum single-charge values of $\mathrm{f}$.

For single row-charges, Table D6 relates overpressures generated by the row-charge $\left(\Delta \mathrm{P}_{r}\right)$ to those generated by a single charge $\left(\Delta \mathrm{P}_{\mathrm{S}}\right)$ weighing the same as the average charge in the row and at the same scaled depth of burial. The number of charges in the row is $n$.

For simultaneous double row-charges near optimum interrow spacing, the overpressures and difference factors were approximately the same as for a single row containing the same number of charges as both double rows; i.e., $\mathrm{n}$ is the total number of charges in both rows.

The single-charge transmission factors (Fig. D1) and row-charge 
difference factors discussed in this chapter may be used as an approximate means of predicting airblast from future events of a similar nature. ${ }^{22}$ 


\section{Appendix $\mathrm{E}$ Laboratory Testing of Fallback Material}

A program of laboratory tests was conducted at the Rockfill Test Facility at the University of California ${ }^{*}$ to measure the physical properties of the fallback in the D4 crater.

The tests described were performed for two purposes. The primary objective was to obtain information that could be used to estimate the amount of timedependent settlement of the fallback, and the amount of settlement that would result from saturation of the fallback by surface water or groundwater. A second objective of the test program was to provide information concerning other physical properties of the fallback, such as grain-size distribution, relative density, and shear strength characteristics, that would add to the available information concerning the engineering characteristics of fallback materials in general.

The rocks, which are composed of quartz, plagioclase and orthoclase feldspars, clay, and minor amounts of ferromagnesian minerals, are soft and poorly cemented. Although they do not slake when placed in water, they are softened by water and many sandstone fragments could be broken easily by hand after soaking in water. The average in situ dry density of the rock before the blast was $150.8 \mathrm{lb} / \mathrm{ft}^{3}$. As described in Chapter 6 , the mass density of $128.8 \mathrm{lb} / \mathrm{ft}^{3}$ was determined by excavating $107.2 \mathrm{yd}^{3}$ from a trench and weighing the material.

\footnotetext{
The Rockfill Test Facility, located at the Richmond Field Station, is operated by the University of California for the California Department of Water Resources.
}

The grain-size was measured using the point-count technique. 17 The fallback contained a few rocks as large as 4 or $5 \mathrm{ft}$, but about $99 \%$ of the particles were smaller than 15 in. The smallest particles were finer than the No. 200 sieve.

Thirty-four tons of the excavated fallback material were trucked to the Rockfill Test Facility for testing. Samples were taken from the material to determine its water content. The entire 34 tons were sieved to determine the grain-size distribution and to separate the material into a number of size fractions, the smallest consisting of material passing the No. 200 sieve. The size fractions were subsequently recombined to form "model" materials with grain-size distribution curves parallel to the iield curve, but with smaller maximum particle sizes. Tests were conducted on these model materials to determine maximum and minimum densities for relative density determinations, and triaxial and onedimensional compression tests were performed to determine the stress-strain and strength characteristics. Tests were conducted on specimens compacted to the in situ relative density and to looser densities.

\section{WATER CONTENT AND IN SITU DRY DENSITY}

Samples from the material received for testing at the Rockfill Test Facility were found to have an average water content of $4.8 \%$, which is about the same value as determined from core samples of the rocks before the blast. Using a water 
content of $4.8 \%$ and the moist unit weight determined by trenching in the fallback $\left(\gamma_{\mathrm{m}}=128.8 \mathrm{lb} / \mathrm{ft}^{3}\right)$ the in situ dry unit weight $\left(\gamma_{\mathrm{d}}\right)$ was calculated to be $123.0 \mathrm{lb} /$ $\mathrm{ft}^{3}$.

GRAIN SIZE DISTRIBUTION, PARTICLE COMPOSITION, AND SPECIFIC GRAVITY

The grain-size distribution curve determined by sieving the fallback material received at the Rockfill Test Facility is shown in Fig. E1, together with curves determined by the point-count technique at the east and the west ends of the crater. The curve determined by sieving lies between the other two curves for the range of sizes larger than about 0.2 in., but shows larger percentages of the finer sizes. It is seen that $23 \%$ of the fallback is finer than the No. 4 sieve, and about $2 \%$ is finer than the No. 200 sieve.
The grain-size distribution curves for the "model" materials are shown in Fig. E2. These curves are parallel to the grain-size curve of the material received for testing, and were selected so that the largest size particles used in each type of test were about one-sixth as large as the minimum dimension of the test specimen.

The material was examined after sieving to determine the compositions and specific gravities of the various size fractions, as shown in Table E1. The shale and siltstone were softer than the sandstone and were therefore broken into smaller particles by the blast. As a result, the smaller particles tend to be somewhat softer than the larger ones. The same would probably be true of any fallback containing rocks with varying hardness. The specific gravities determined for the various size fractions

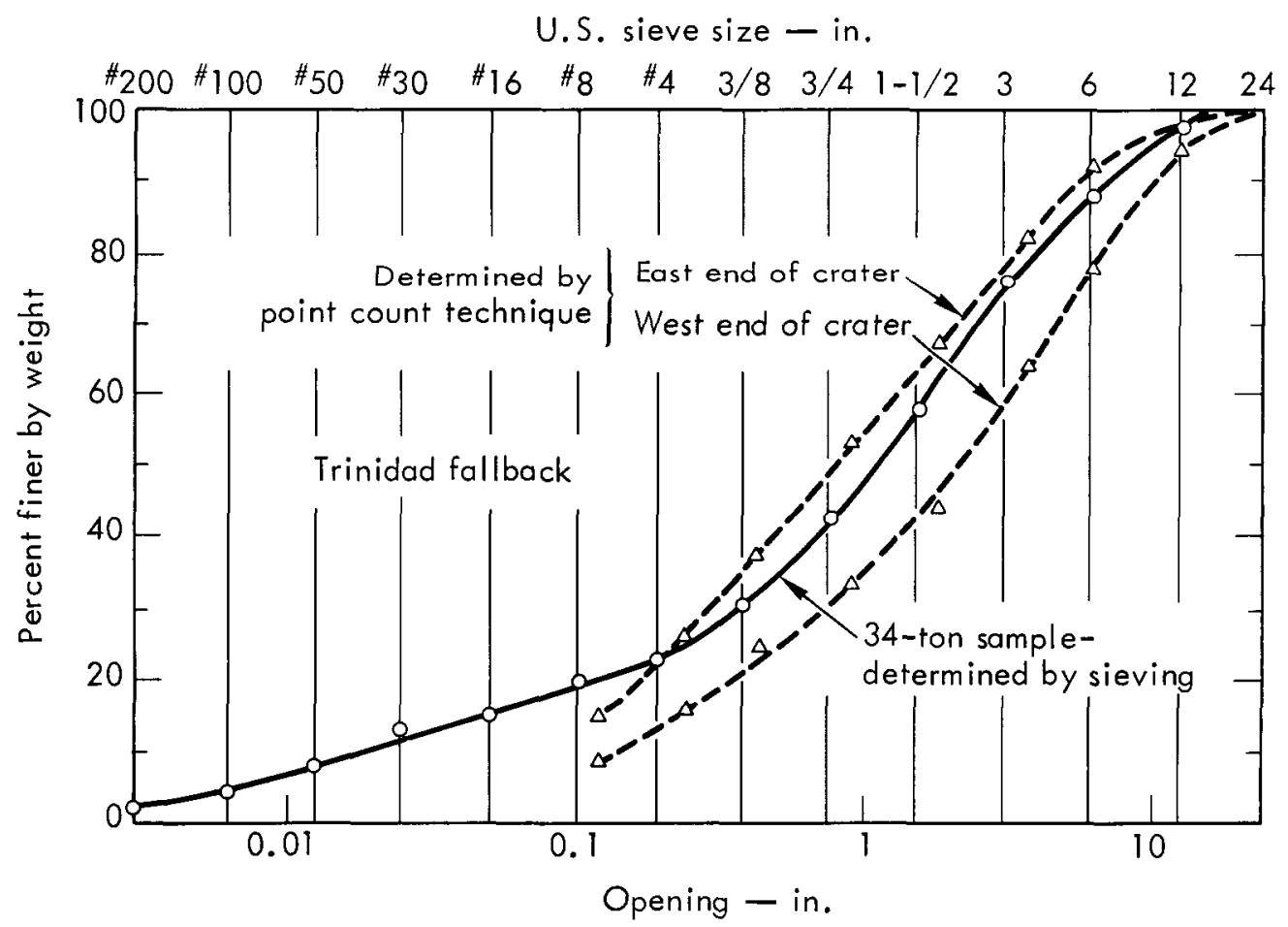

Fig. E1. Comparison of grain-size distribution curves determined by point count technique and by sieving. 


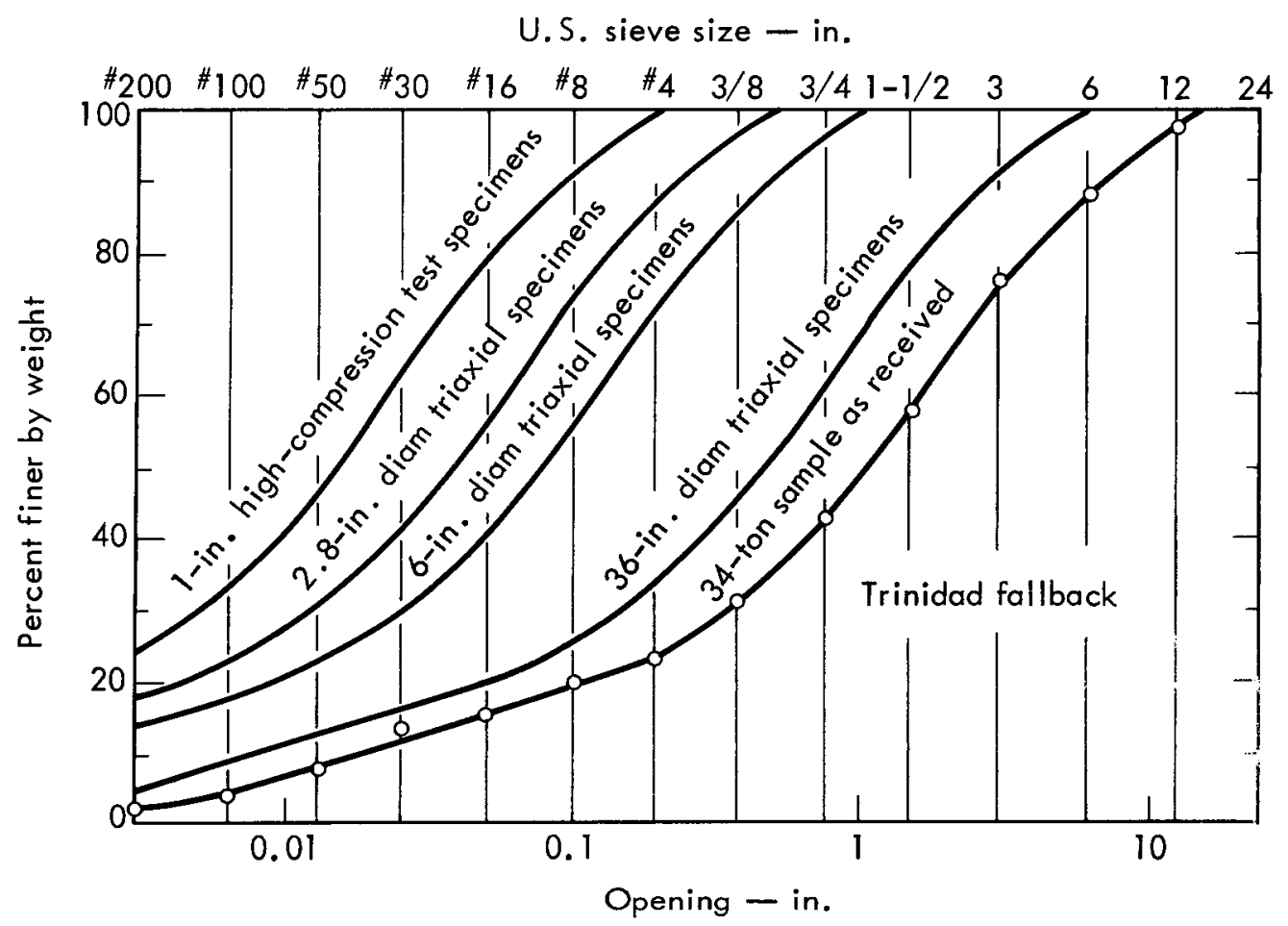

Fig. E2. Grain-size distribution curves for material as received and for test specimens.

Table E1. Composition and specific gravities of various sized fractions of Trinidad fallback.

\begin{tabular}{|c|c|c|c|}
\hline $\begin{array}{l}\text { Size fraction } \\
\text { (in.) }\end{array}$ & $\begin{array}{l}\text { Percent } \\
\text { sandstone }\end{array}$ & $\begin{array}{l}\text { Percent shale } \\
\text { and siltstone }\end{array}$ & $\begin{array}{l}\text { Specific } \\
\text { gravity }\end{array}$ \\
\hline 6 to 3 & 91 & 9 & 2.60 \\
\hline 3 to $1-1 / 2$ & 98 & 2 & - \\
\hline $1-1 / 2$ to $3 / 4$ & 84 & 16 & 2.64 \\
\hline $3 / 4$ to $3 / 8$ & 67 & 33 & - \\
\hline $3 / 8$ to No. 4 & - & - & 2.66 \\
\hline No. 4 to No. 8 & 50 & 50 & - \\
\hline $\begin{array}{c}\text { All material } \\
\text { finer than No. } 4\end{array}$ & - & - & 2.60 \\
\hline
\end{tabular}

varied from 2.60 to 2.66 , with an average value of 2.63 .

\section{RELATIVE DENSITY}

Tests were performed to determine the maximum and minimum densities for four "model" materials having grain-size distribution curves parallel to that for the field material, but smaller maximum particle sizes. Tests were performed on materials with maximum particles sizes equal to 2 in., 1 in., $1 / 2$ in., and the No. 4 sieve size. The results of these tests 
are shown in Fig. E3. The maximum and minimum densities increase with increasing maximum particle size. Extrapolating the experimental curves to a maximum particle size of 15 in., it was estimated that the maximum density of the material with the field gradation would be about $130.0 \mathrm{lb} / \mathrm{ft}^{3}$, and the minimum about $109.5 \mathrm{lb} / \mathrm{ft}^{3}$. Using these values of maximum and minimum density, it was determined that the relative density of the fallback in the field was about $70 \%$.

This relative density of the fallback in the field is somewhat higher than was anticipated. However, studies by Walker and Whitake ${ }^{21}$ and Silver and Seed ${ }^{23}$ have shown that uniform sands can be compacted efficiently by "pluvial compaction," or dropping into place. Silver and Seed found that a uniform, angular silica sand that they tested could be compacted to as high as $95 \%$ relative density by pluvial compaction. To the writers' knowledge, no studies have been performed to determine the effectiveness of pluvial compaction for well-graded materials like the Trinidad fallback.

\section{TRLAXIAL TESTING}

Most of the triaxial and one-dimensional compression test specimens were formed at relative densities close to those determined for the fallback in the field, in order that the results of the tests could be used to evaluate the properties of the material at its in situ density. A few tests on smaller size specimens were performed at looser densities to investigate the effects of changes in density on the strength, compressibility, and compression due to wetting.

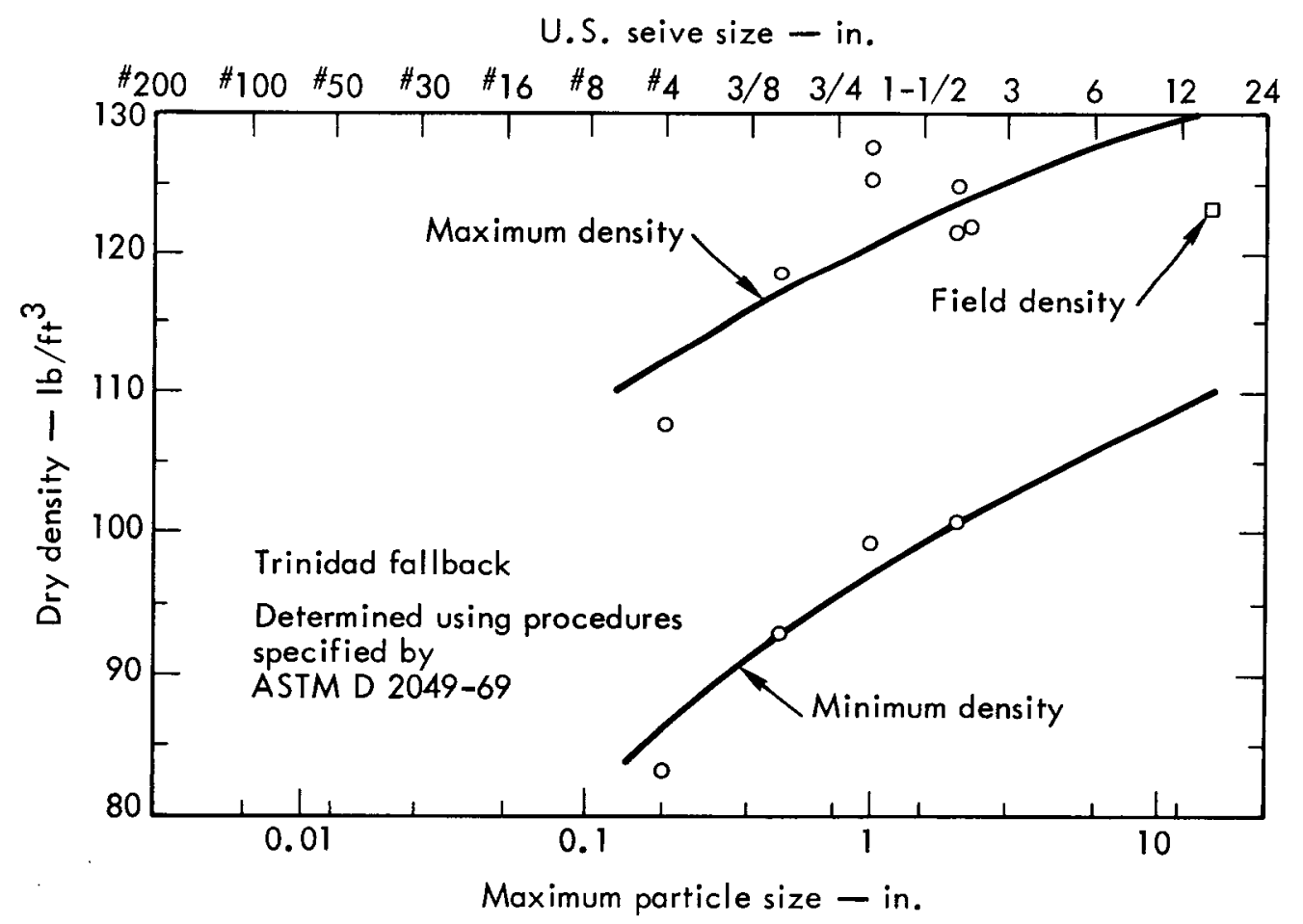

Fig. E3. Variations of maximum and minimum density with maximum particle size. 
Four drained triaxial tests were performed on 36-in. diameter specimens containing particles as large as 6 in. The grain-size distribution curves for the material tested are shown in Fig. E2. The specimens were compacted to dry densities ranging from $119.6 \mathrm{lb} / \mathrm{ft}^{3}$ to $120.6 \mathrm{lb} / \mathrm{ft}^{3}$, which corresponds to relative densities of $71 \pm 2 \%$, very close to the field value.

Two tests were conducted on material that was compacted and tested at water contents of $5 \%$, essentially the same as the field value. The second two specimens were saturated after compaction by circulating water through them and by applying back pressure. The permeability of the material was quite low, and considerable time was required to saturate the specimens. After the tests the wet specimens did not drain; they had considerable cohesion and were able to stand unsupported, as shown in Fig. E4.

The stress-strain and volume change curves for the two tests performed using $\sigma_{3}=15$ psi are shown in Fig. E5, and those for tests conducted with $\sigma_{3}=30 \mathrm{psi}$ are shown in Fig. E6. The stress-strain curves shown in Figs. E5 and E6 and in other figures in this report have not been corrected for the loads carried by the rubber membranes used to confine the specimens. The loads are not very large, however, and applying the appropriate correction to the axial stress results in a reduction in the maximum principal stress ratio of the order of 0.1 , or about $2 \%$. Although the values of principal stress ratio shown on the stress-strain curves have not been corrected, the stresses at failure have been corrected for the purpose of calculating the angles

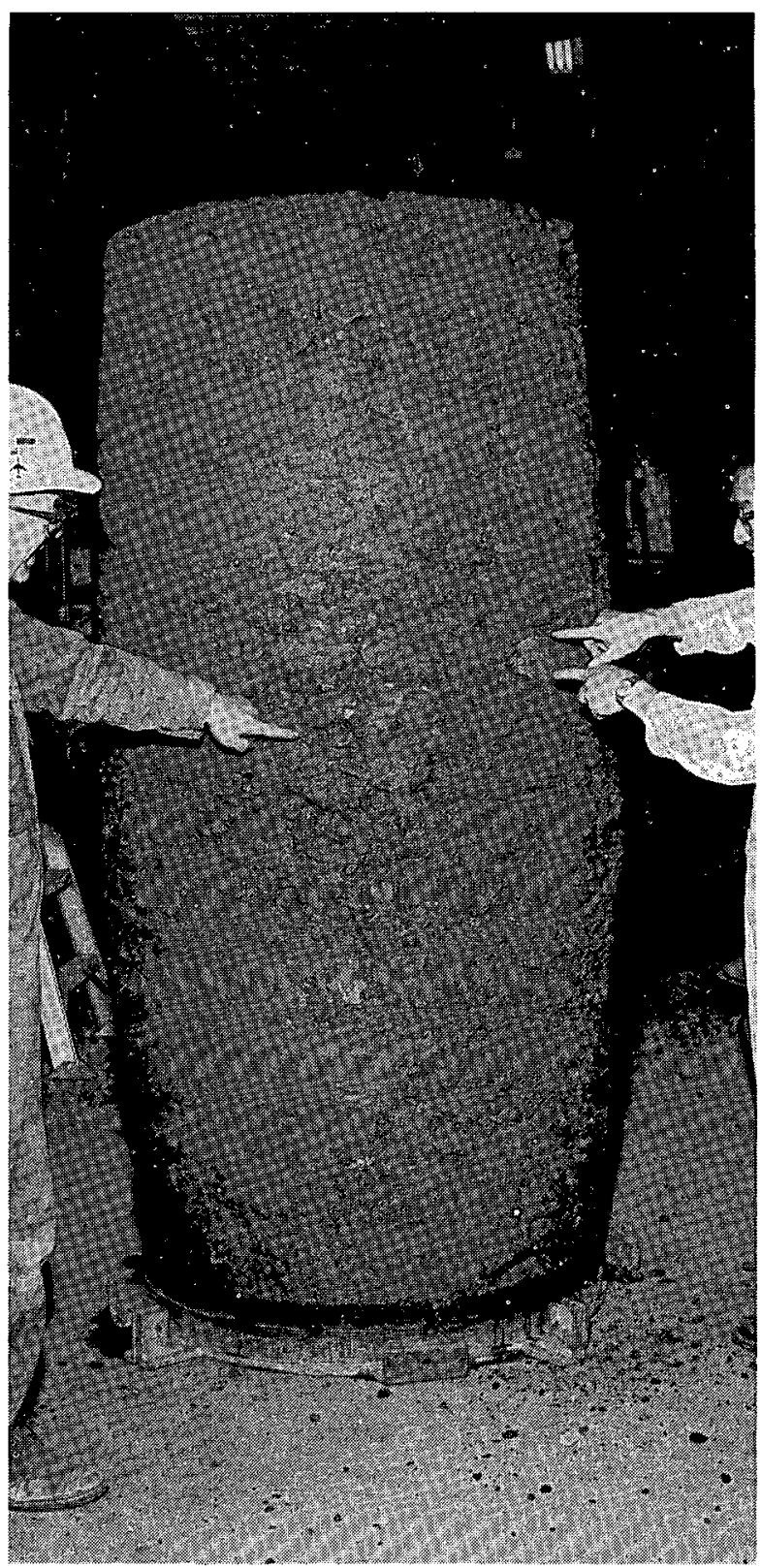

Fig. E4. Wet specimen (36-in. diameter) after testing.

of internal friction, which are discussed in a subsequent section.

It may be noted that the wet specimens were considerably weaker than the dry ones. The stress-strain curves for the wet specimens are flatter than for the dry ones tested at the same pressure, and the peak values of principal stress ratio are smaller. It may also be seen 


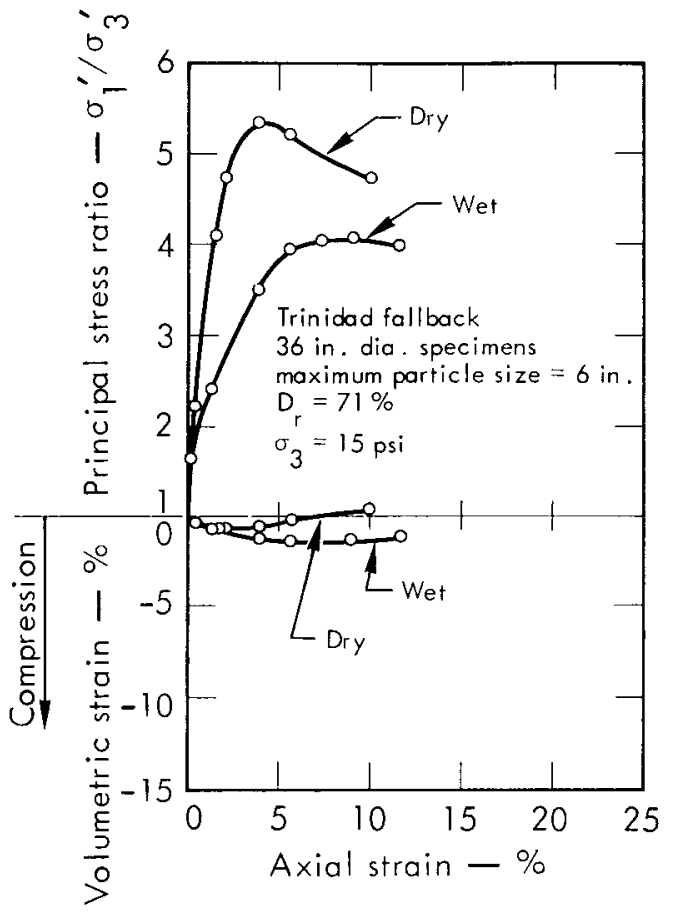

Fig. E5. Stress-strain and volume change curves for specimens compacted to $71 \%$ relative density (confining pressure, 15 psi).

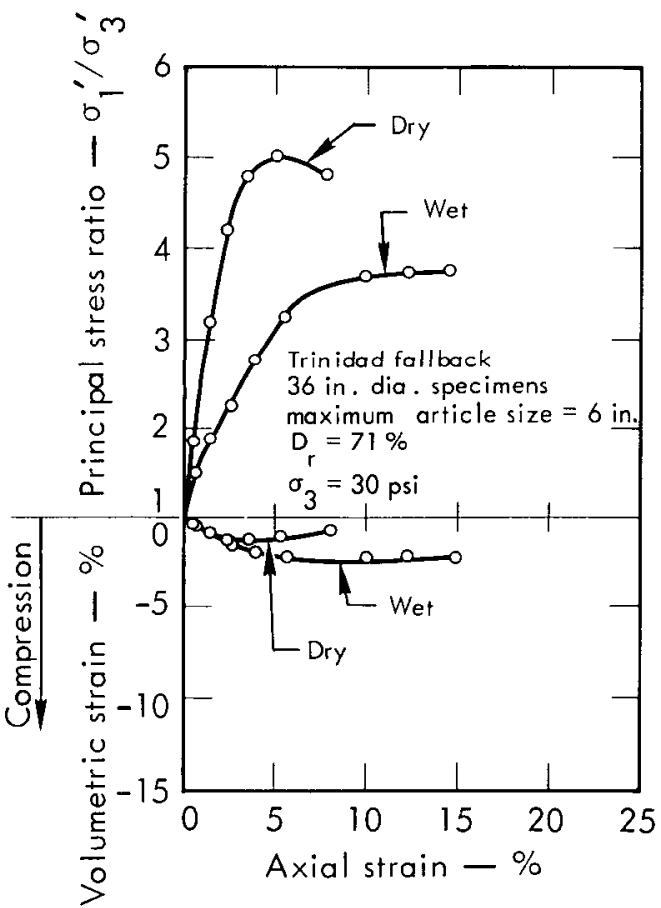

Fig. E6. Stress-strain and volume change curves for specimens compacted to $71 \%$ relative density (confining pressure, $30 \mathrm{psi}$ ). that the wet specimens compressed more during shear than the dry ones. The material is quite compressible; even at the low confining pressures employed in the tests, the volumes of all the specimens decreased during shear.

Four drained triaxial tests were conducted on 6-in. diameter specimens. As was the case in the tests on 36-in. diameter specimens, two specimens were tested wet and two were tested dry, using confining pressure of 15 and $30 \mathrm{psi}$. The maximum particle size in the 6 -in diameter specimens was $1-i n$. The specimens were prepared at densities of 114.1 to $114.8 \mathrm{lb} / \mathrm{ft}^{3}$, correspond to relative densities of $77 \pm 1 \%$.

The stress-strain curves for the tests are shown in Figs. E7 and E8. As in the case of the 36-in. diameter specimens,

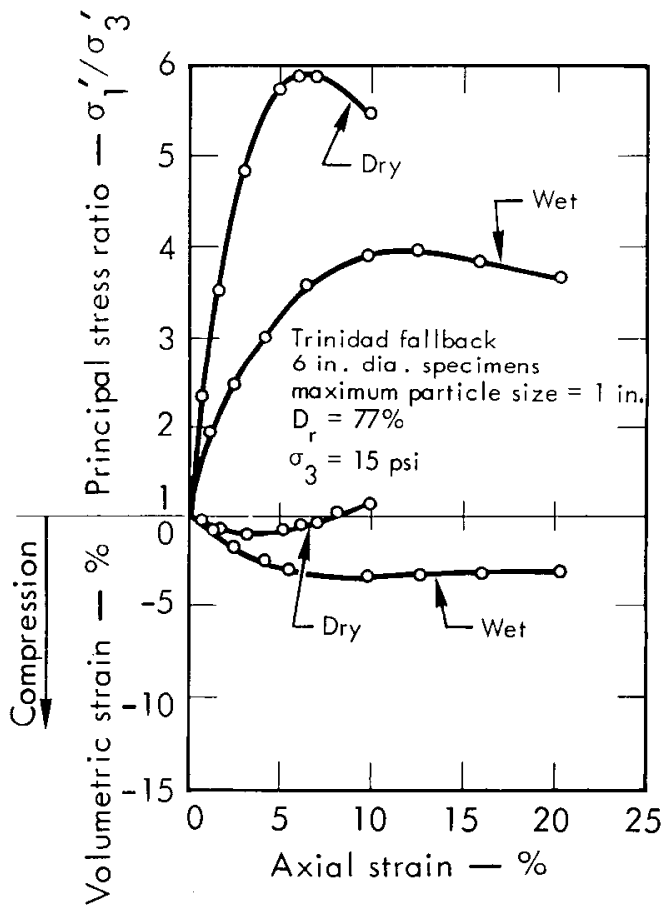

Fig. E7. Stress-strain and volume change curves for specimens compacted to $77 \%$ relative density (confining pressure, 15 psi). 


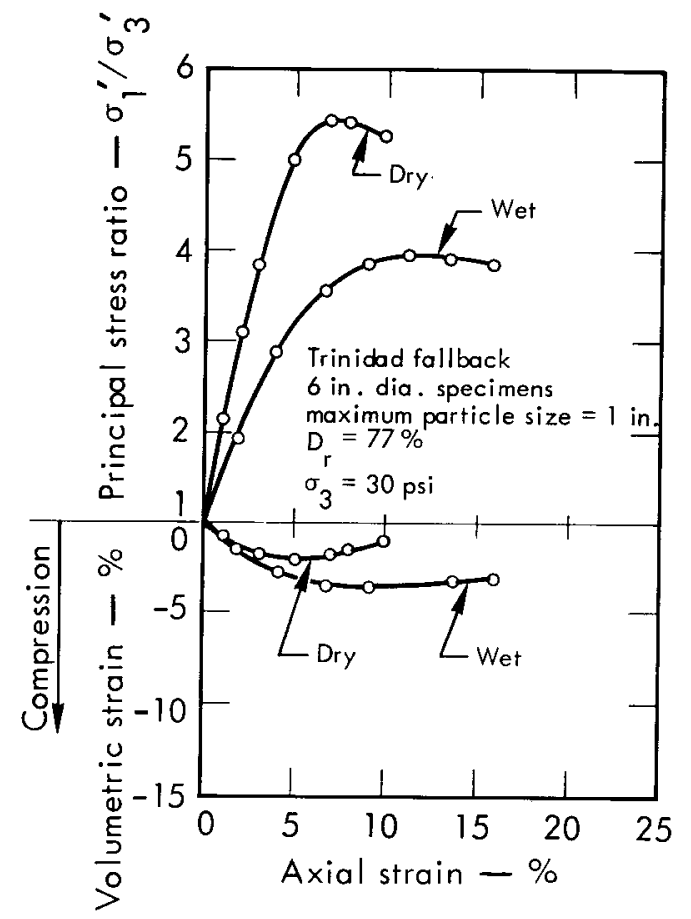

Fig. E8. Stress-strain and volume change curves for specimens compacted to $77 \%$ relative density (confining pressure, 30 psi).

the specimens tested wet were considerably weaker than the dry ones, and compressed more during shear.

Eight drained triaxial tests were conducted on 2.8-in. diameter specimens, with materials having a maximum particle size of $0.47 \mathrm{in.}$ Two of these tests were conducted on wet specimens that were compacted to dry densities of $108.8 \mathrm{lb} / \mathrm{ft}^{3}$ and $109.3 \mathrm{lb} / \mathrm{ft}^{3}$, corresponding to relative densities of $71 \%$ and $73 \%$. The stress-strain curves for these tests are shown in Figs. E9 and E10, together with stress-strain curves for dry material at the same relative density estimated from the results of tests on dry specimens at higher and lower densities.

The remaining six tests on 2.8-in. diameter specimens were conducted on dry specimens with relative densities

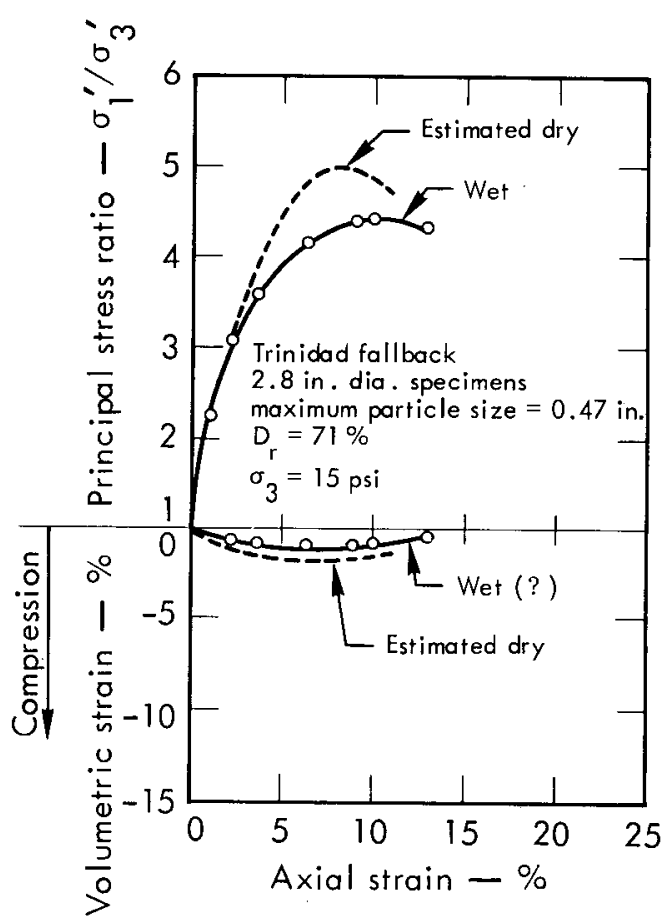

Fig. E9. Stress-strain and volume change curves for specimens compacted to $73 \%$ relative density (confining pressure, 15 psi).

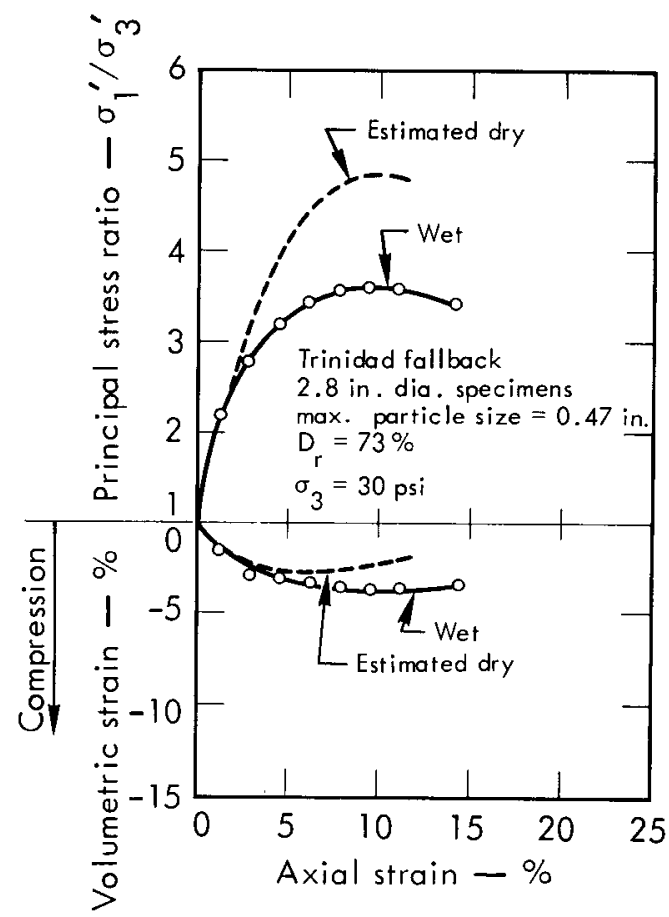

Fig. E10. Stress-strain and volume change curves for specimens compacted to $73 \%$ relative density (confining pressure, $30 \mathrm{psi}$ ). 
ranging from $54.5 \%$ to $80.5 \%$. The stressstrain and volume change curves for these tests are shown in Figs. E11 and E12.

\section{ONE-DIMENSIONAL COMPRESSION TESTS}

Eight one-dimensional compression tests were conducted on material having a gradation curve parallel to the field gradation curve and a maximum particle size equal to the No. 4 sieve. The tests were conducted on specimens confined in 4 -in. diameter, 1-in. high Teflon-lined consolidation rings. Two series of tests were performed, one on specimens compacted to $80 \%$ relative density, and the other on specimens compacted to $50 \%$ relative density.

The compression-time curves for one of these tests is shown in Fig. E13. The specimen was compacted dry-to- $80 \%$ relative density and was then subjected to a pressure of $10 \mathrm{psi}$. Application of this pressure resulted in an immediate axial compression of about $0.8 \%$, followed by a small amount of time-delayed compression. Similarly, increasing the pressure to $20 \mathrm{psi}$ and then to $30 \mathrm{psi}$ resulted in further immediate compression followed by creep at a slow rate.

As shown in Fig. E13, adding water to the specimen while the pressure was maintained at 30 psi caused a large increase in the settlement rate. Over a period of $100 \mathrm{~min}$. after the water was added, the settlement increased from about 2.8 to about $9.4 \%$.

The results for all four onedimensional compression tests performed on specimens compacted to $80 \%$ relative density are shown in Fig. E14. These four specimens were wetted while

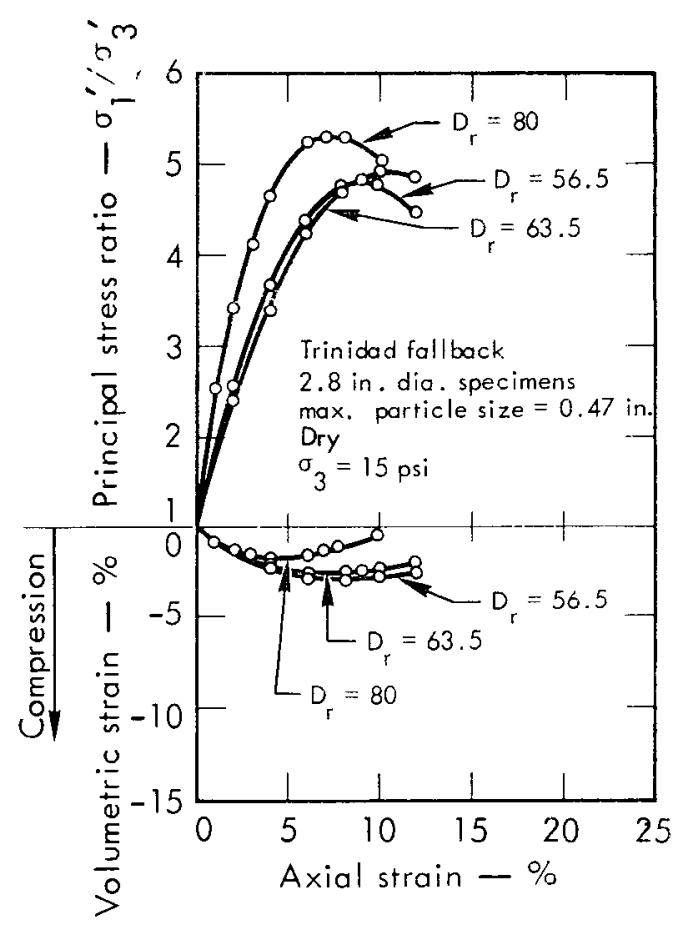

Fig. E11. Stress-strain and volume change curves for specimens compacted to three relative densities (confiring pressure, 15 psi).

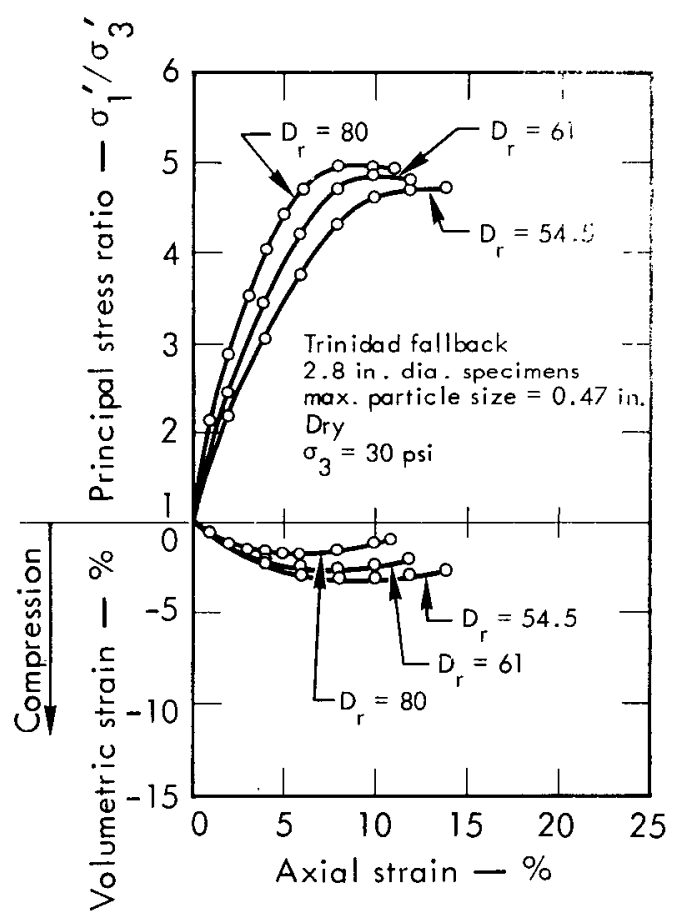

Fig. E12. Stress-strain and volume change curves for specimens compacted to three relative densities (confining pressure, $30 \mathrm{psi}$ ). 


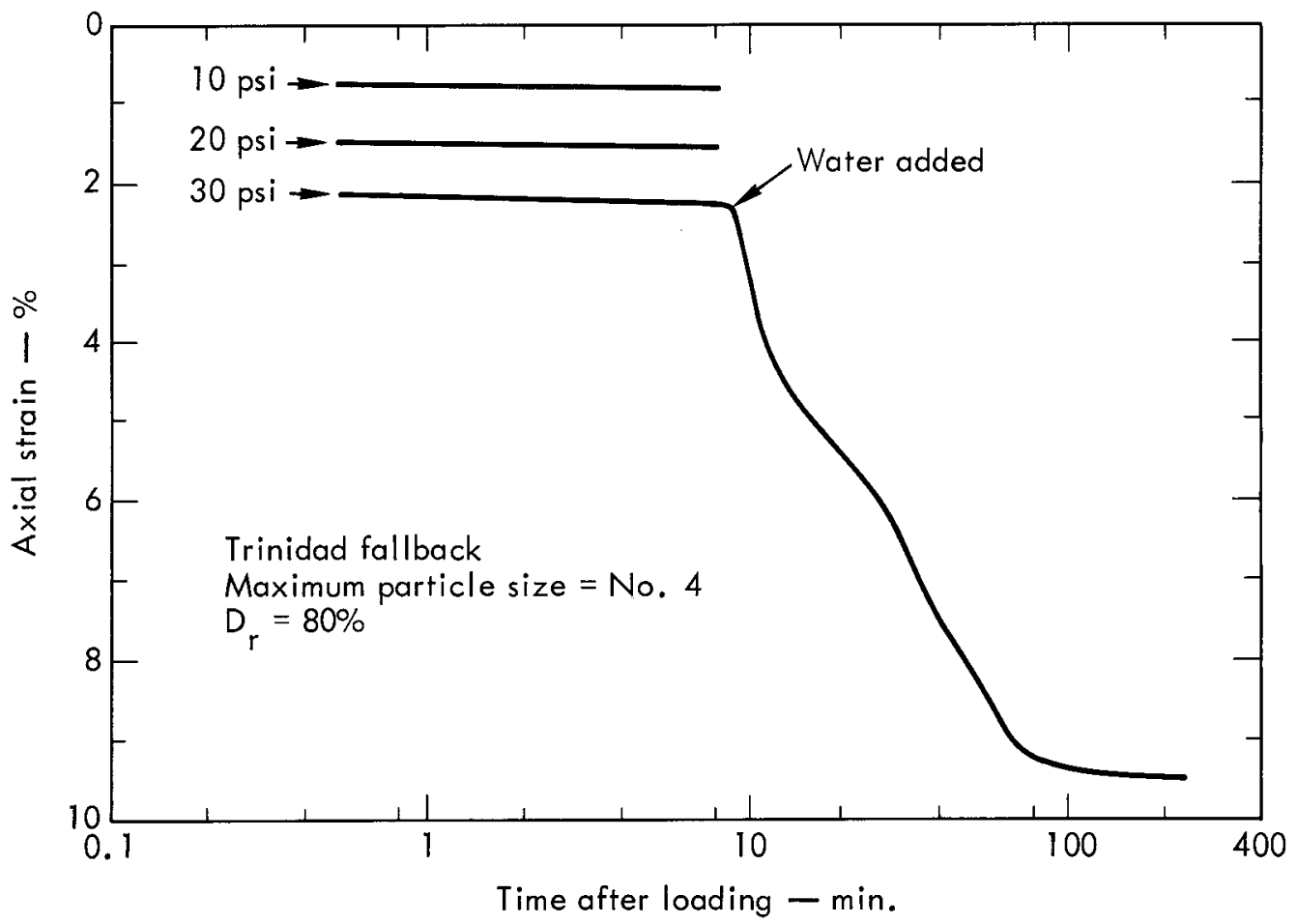

Fig. E13. Compression time curves for specimens compacted to $80 \%$ relative density.

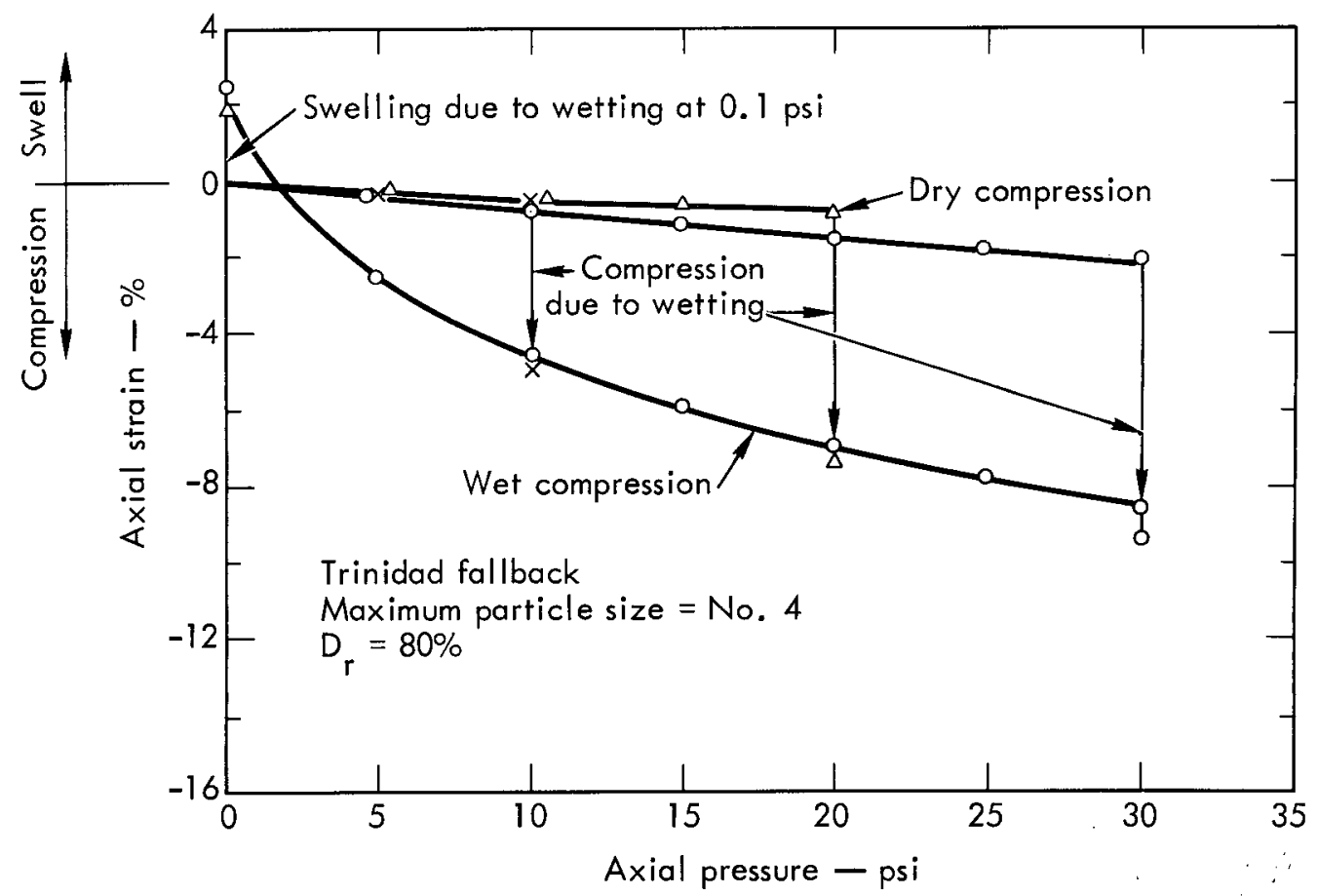

Fig. E14. One-dimensional compression curves for specimens compacted to $80 \%$ relative density. 
subjected to pressures of $30,20,10$, and $0.1 \mathrm{psi}$. The specimen which was wetted at $0.1 \mathrm{psi}$ swelled about $2.6 \%$ when the water was added, but all the others compressed upon wetting. Similar results for specimens compacted to $50 \%$ relative density are shown in Fig. E15. As would be expected, the amount of swell induced by wetting at the lowest pressure was smaller, and the amounts of compression due to wetting at higher pressures were larger for these looser specimens.

As for other soils tested previously, the amounts of compression induced by wetting the specimens after loading were approximately equal to the difference in the amounts of compression for wet and dry specimens at the same pressure. Thus the amount of compression due to wetting at any pressure can be estimated with compression curves for wet and dry specimens.
PARTICLE BREAKAGE

Several specimens were sieved to determine the amount of particle breakage during testing. The results are shown in Table 2 in terms of the particle breakage factor $\mathrm{B}$, defined by Marsal. ${ }^{24}$ This factor is the sum of the differences (of the same sign) in the percentages retained on each sieve before and after a test. Larger values of $\mathrm{B}$ indicate more change in gradation and more particle breakage during the test. The data in Table E2 indicate that the particle breakage was

Table E2. Values of particle breakage factor $B$ determined by resieving triaxial specimens after testing.

\begin{tabular}{|c|c|c|c|c|c|c|}
\hline \multirow{3}{*}{$\begin{array}{l}\text { Confining } \\
\text { pressure } \\
\text { (psi) }\end{array}$} & \multicolumn{6}{|c|}{ Specimen diameter } \\
\hline & \multicolumn{2}{|c|}{36 in. } & \multicolumn{2}{|c|}{6 in. } & \multicolumn{2}{|c|}{$2.8 \mathrm{in}}$. \\
\hline & $\begin{array}{c}\text { Dry } \\
(\%)\end{array}$ & $\begin{array}{c}\text { Wet } \\
(\%)\end{array}$ & $\begin{array}{c}\text { Dry } \\
(\%)\end{array}$ & $\begin{array}{l}\text { Wet } \\
(\%)\end{array}$ & $\begin{array}{c}\text { Dry } \\
(\%)\end{array}$ & $\begin{array}{l}\text { Wet } \\
(\%)\end{array}$ \\
\hline 15 & 6 & 18 & 11 & 26 & 10 & 21 \\
\hline 30 & 6 & 15 & 10 & 23 & 9 & 17 \\
\hline
\end{tabular}

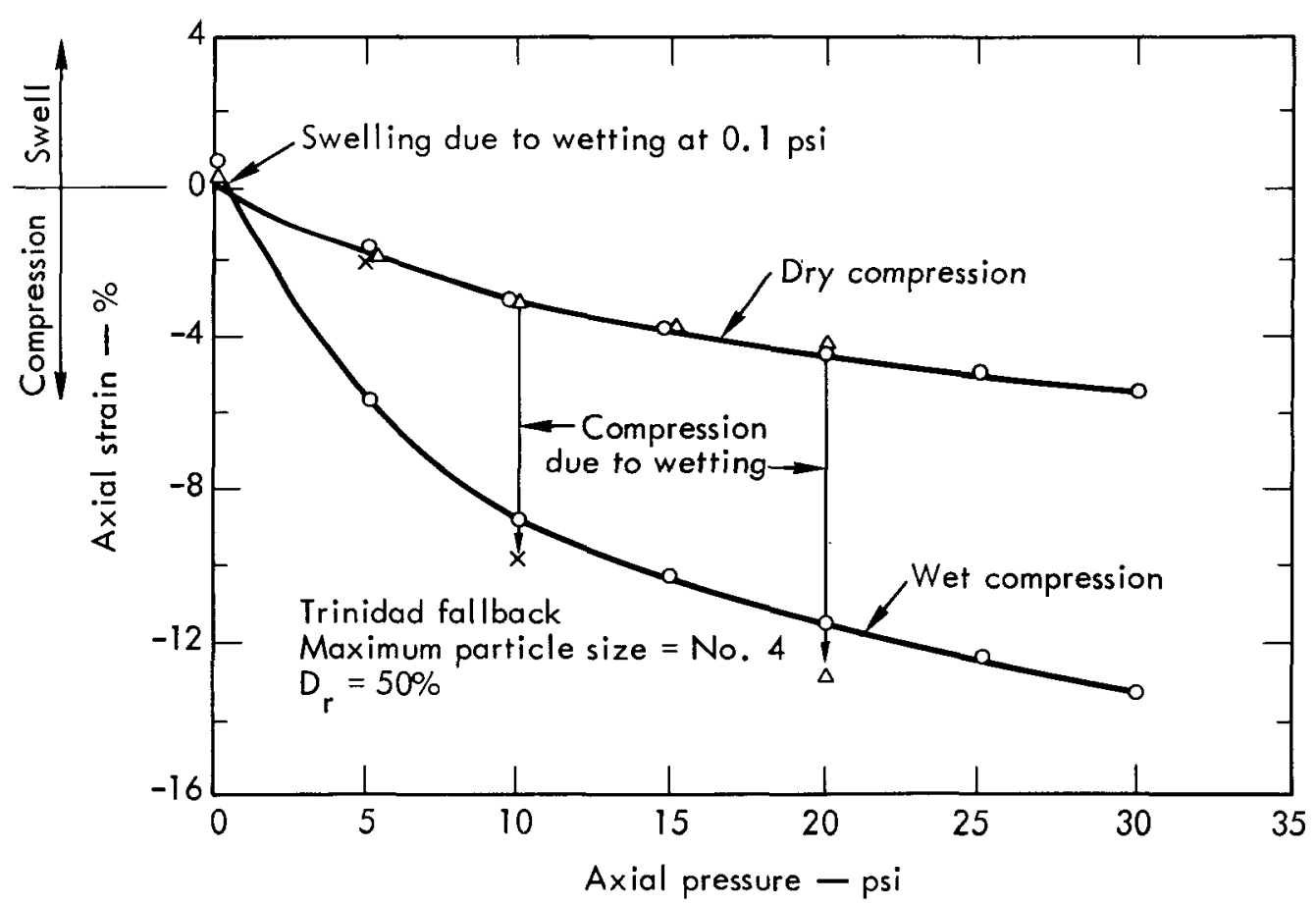

Fig. E15. One-dimensional compression curves for specimens compacted to $50 \%$ relative density. 
greater for the wet than for the dry specimens. It may also be noted that there was more breakage for the smaller specimens that contained smaller, softer particles.

\section{SUMMARY OF LABORATORY TEST PROGRAM}

The relative density of the fallback in the field is perhaps the most important factor controlling its shear strength, compressibility, compression upon wetting, and susceptibility to settlements or liquefaction during earthquakes. Materials with relative densities as high as that determined for the Trinidad fallback $(70 \%)$ are nearly as dense as wellengineered fills and should thus not be susceptible to severe problems of settlement and stability.

In order to determine the relative density of the fallback in the field, it was necessary to extrapolate on the basis of minimum and maximum density values determined for model materials with smaller maximum particle sizes. Because of the importance of knowing the relative densities accurately, it would be desirable to study the effectiveness of pluvial compaction for well-graded fallback materials. If enough data could be obtained for various types of materials, it might be feasible to predict the relative density based on small-scale laboratory and/or field tests conducted before the crater was made.

The results of all the triaxial tests performed are summarized in Table E3, and the measured values of $\phi$ are plotted against the relative densities of the test specimens in Fig. E16. All of the values shown in Fig. E16 are for tests conducted with $\sigma_{3}=15$ psi; as shown in Table E3, the values of $\phi$ are about 1 to 2 deg lower for tests conducted with $\sigma_{3}=30$ psi.

It may be seen that the angles of internal friction are about 6 deg lower on the average for wet specimens than for dry ones. The values of $\phi$ measured for all three specimen sizes are in fairly good agreement, indicating that it would be possible to determine the angle of internal friction with reasonable accuracy by testing "model" materials, even though the particles in the various size ranges vary in hardness.

For the in situ relative density of $70 \%$, the angle of internal friction for the material in a dry condition is about $43 \mathrm{deg}$, and for the material in a wet condition, about $36.5 \mathrm{deg}$. These values correspond to $\sigma_{3}=15 \mathrm{psi}$ as in Fig. E16; the values of $\phi$ for both wet and dry conditions would be somewhat smaller for higher confining pressures.

The values of volumetric strain due to wetting measured in the triaxial and one-dimensional compression tests are shown in Fig. E17, plotted against the maximum particle sizes. It may be seen that the specimens composed of smaller sizes underwent much more compression due to wetting than did those containing larger particles. By extrapolating the curves to the maximum particle size in the field (about 15 in.), it is possible to estimate the amount of settlement which would be induced by wetting. As may be seen for the data obtained in onedimensional compression tests on specimens composed of material with No. 4 maximum particle size, the compression induced by wetting under at-rest pressure conditions is about $20 \%$ greater than 
Table E3. Summary of triaxial test results.

\begin{tabular}{|c|c|c|c|c|c|c|}
\hline Test & $\begin{array}{l}\text { Maximum } \\
\text { particle } \\
\text { size } \\
\text { (in.) }\end{array}$ & $\begin{array}{c}\text { Confining } \\
\text { pressure, } \\
\sigma_{3} \\
\text { (psi) }\end{array}$ & $\begin{array}{c}\text { Density, } \\
\gamma_{\mathrm{d}} \\
\left(\mathrm{lb} / \mathrm{ft}^{3}\right)\end{array}$ & $\begin{array}{c}\text { Relative } \\
\text { density, } \\
\mathrm{D}_{\mathrm{r}} \\
(\%)\end{array}$ & $\begin{array}{l}\text { Principal } \\
\text { stress } \\
\text { ratio, } \\
\left(\frac{\sigma_{1}^{\prime}}{\sigma_{3}^{\prime}}\right)_{\mathrm{f}}\end{array}$ & $\begin{array}{c}\text { Angle of } \\
\text { internal } \\
\text { friction, } \\
\phi \\
\text { (deg) }\end{array}$ \\
\hline 36-in. Dry & 6 & 15 & 120.3 & 71.5 & 5.32 & 43.1 \\
\hline 36-in. Dry & 6 & 30 & 120.3 & 71.5 & 4.95 & 41.5 \\
\hline 36-in. Wet & 6 & 15 & 120.6 & 73.0 & 3.82 & 35.8 \\
\hline 36-in. Wet & 6 & 30 & 119.6 & 69.0 & 3.58 & 34.3 \\
\hline 6-in. Dry & 1 & 15 & 114.1 & 76.0 & 5.92 & 45.3 \\
\hline 6-in. Dry & 1 & 30 & 114.3 & 76.0 & 5.44 & 43.6 \\
\hline 6-in. Wet & 1 & 15 & 114.8 & 78.0 & 4.08 & 37.3 \\
\hline 6 -in. Wet & 1 & 30 & 114.5 & 77.0 & 3.98 & 36.7 \\
\hline 2.8-in. Dry & 0.47 & 15 & 111.3 & 80.5 & 5.23 & 42.8 \\
\hline 2.8-in. Dry & 0.47 & 30 & 111.0 & 79.5 & 4.93 & 41.5 \\
\hline 2.8-in. Dry & 0.47 & 15 & 106.8 & 63.5 & 4.76 & 40.8 \\
\hline 2.8-in. Dry & 0.47 & 30 & 106.1 & 61.0 & 4.81 & 40.0 \\
\hline 2.8-in. Dry & 0.47 & 15 & 105.0 & 56.5 & 4.87 & 41.2 \\
\hline 2.8-in. Dry & 0.47 & 30 & 104.5 & 54.5 & 4.65 & 40.2 \\
\hline 2.8-in. Wet & 0.47 & 15 & 108.8 & 71.0 & 4.21 & 38.0 \\
\hline 2.8 -in. Wet & 0.47 & 30 & 109.3 & 73.0 & 3.65 & 34.7 \\
\hline
\end{tabular}

the volumetric strain induced by wetting in triaxial tests with the specimens confined under equal all-around pressures.

Using the extrapolated curves shown in Fig. E17 and allowing for about 20\% higher volumetric strains under at-rest pressure conditions, it is estimated that the compression due to wetting would amount to about $0.9 \%$ with overburden pressure $\left(\sigma_{1}\right)$ equal to $15 \mathrm{psi}$, and about $1.5 \%$ with overburden pressure equal to 30 psi. These values are plotted in Fig. E18, which shows the relationship between the overburden pressure and the percent compression due to wetting under at-rest pressure conditions.
With this curve, calculations have been made to determine the settlements to be expected in fallback layers of various thicknesses if the groundwater rose to within $5 \mathrm{ft}$ of the ground surface. The results of these calculations are shown in Table E4. It may be seen that the expected settlements due to groundwater-rise exceed one-tenth of a foot for layers more than $20 \mathrm{ft}$ thick, and that they are more than $0.2 \mathrm{ft}$ for layers thicker than about $30 \mathrm{ft}$. The results would be somewhat different if the groundwater rose to some level other than $5 \mathrm{ft}$ beneath the surface, but the settlements due to wetting could be estimated using the same procedures. 


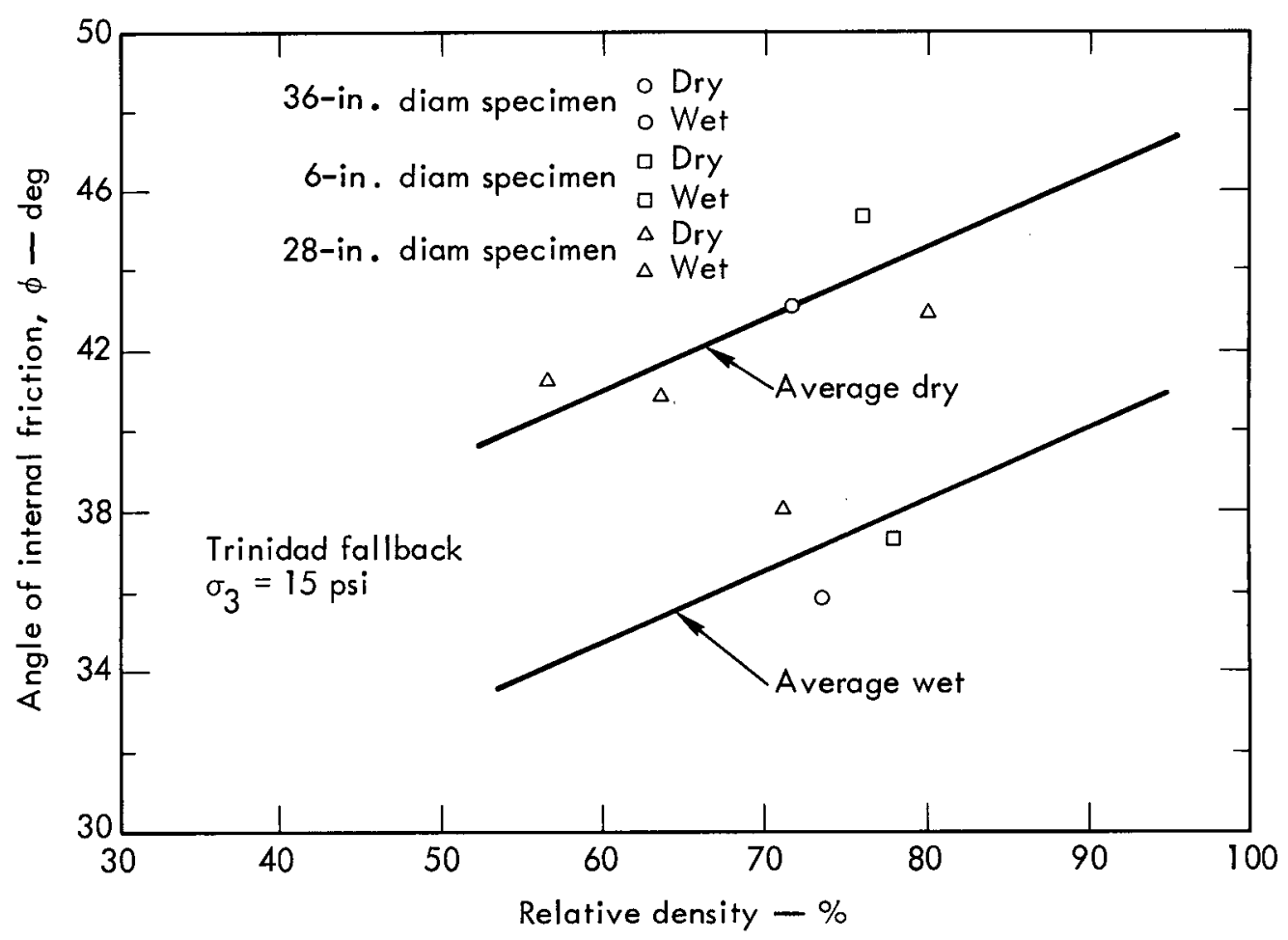

Fig. E16. Variations of angle of internal friction with relative density.

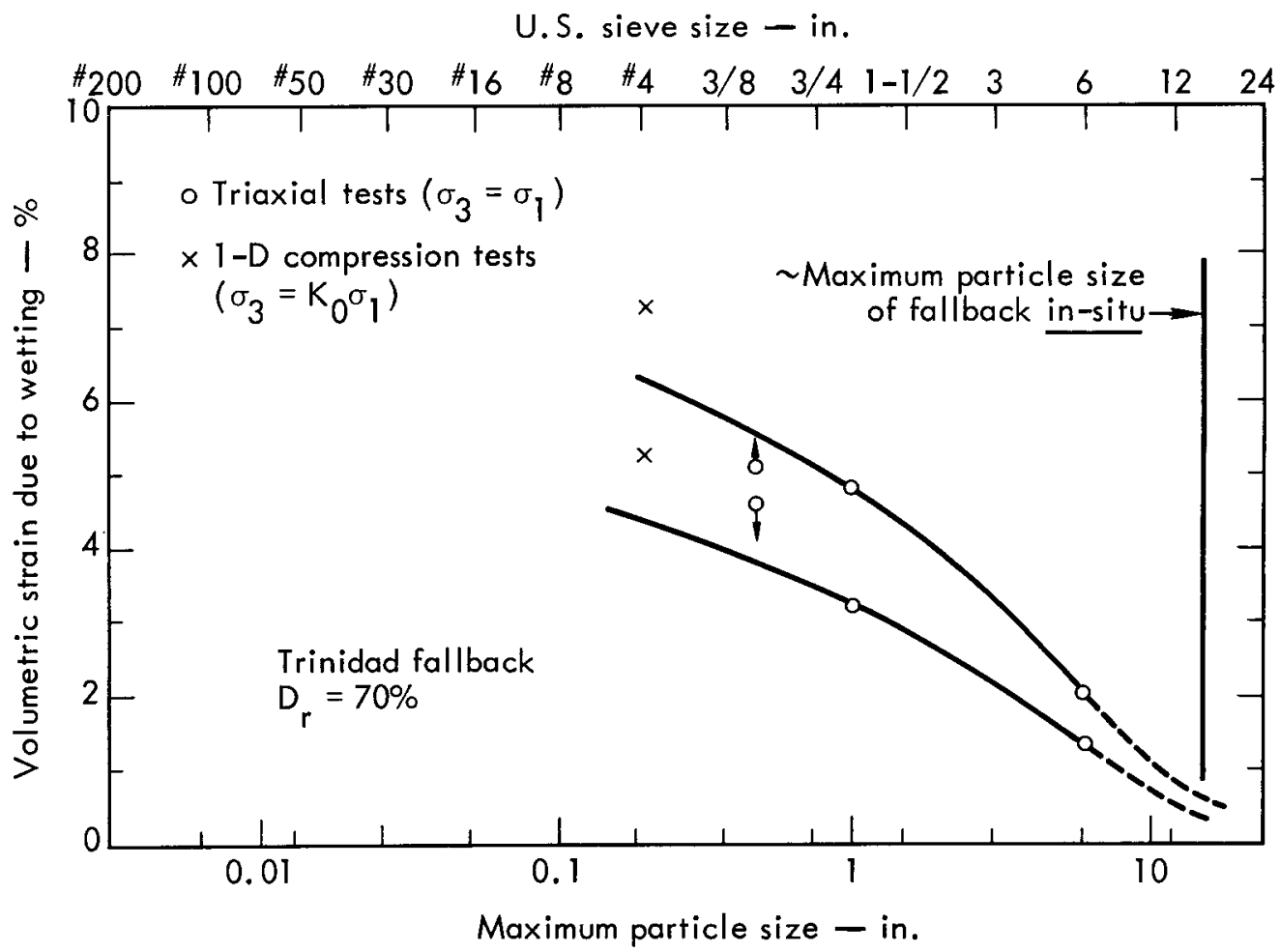

Fig. E17. Variation of volumetric strain due to wetting with maximum particle size. 


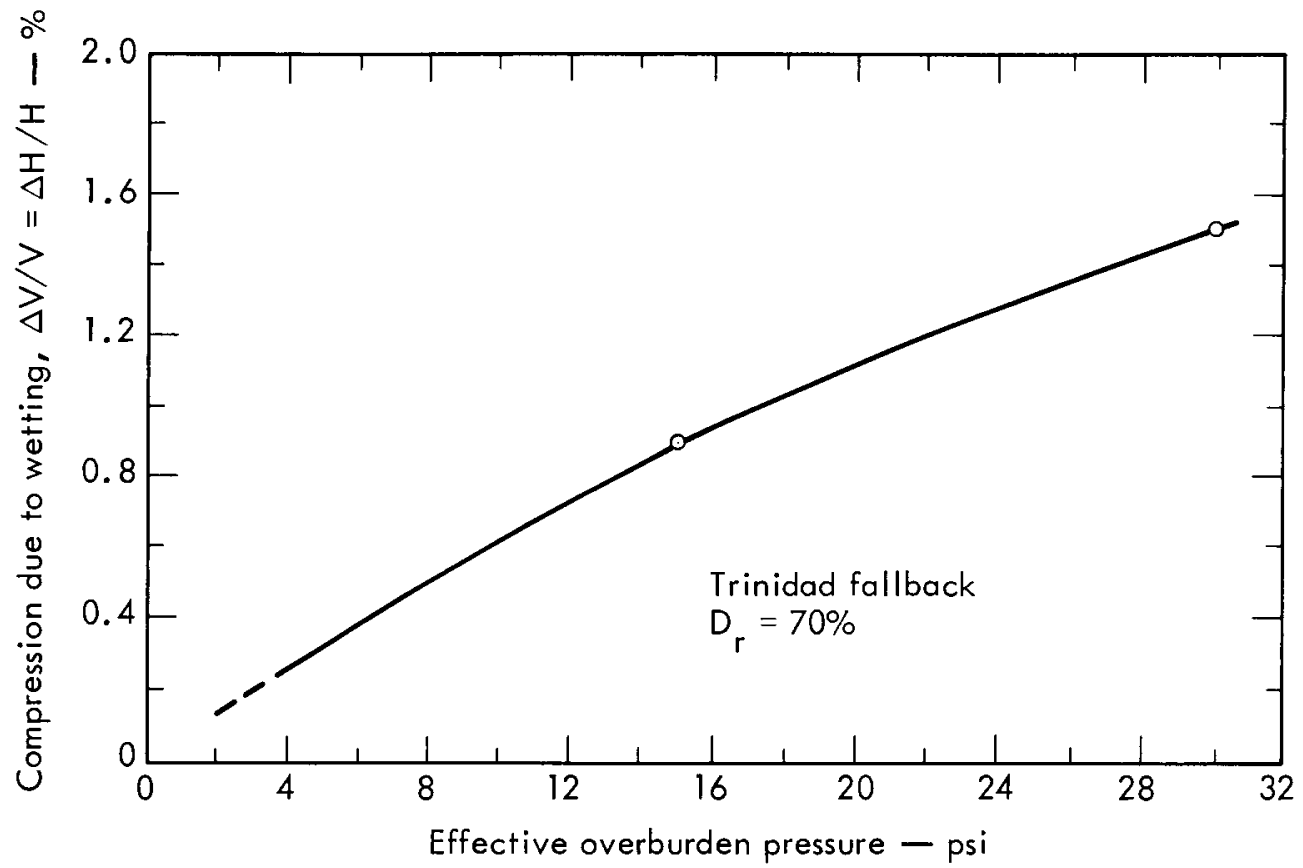

Fig. E18. Variation of compression due to wetting with overburden pressure for at-rest pressure conditions.

A small amount of creep settlement of the fallback would be expected even if the groundwater did not rise. The curves shown in Fig. E13 indicate that the compression of the dry fallback continues to increase approximately linearly with the logarithm of time. The time curves shown in Fig. E13 indicate that the settlement rate is independent of pressure, and amounts to about $0.1 \%$ per log cycle of time. Thus the creep settlement of a 10-ft thick layer would be expected to amount to about $0.01 \mathrm{ft}$ in the period from 3 to 30 days, an additional $0.01 \mathrm{ft}$ in the period from 30 days to about $1 \mathrm{yr}$, another $0.01 \mathrm{ft}$ in the period from 1 to $10 \mathrm{yr}$, and so on. These creep settlement rates are quite small and are not considered to be significant.

Settlement of the fallback would also be caused by increased static pressures from fills placed on the fallback or from slowly moving trains. The magnitudes of these settlements could be estimated
Table E4. Surface settlement due to groundwater rise within $5 \mathrm{ft}$ of ground surface for various fallback layer thicknesses.

\begin{tabular}{|c|c|c|c|c|}
\hline $\begin{array}{c}\text { Layer } \\
\text { thickness, } \\
T \\
\text { (ft) }\end{array}$ & $\begin{array}{l}\text { Height of } \\
\text { ground- } \\
\text { water rise, } \\
\text { H } \\
\text { (ft) }\end{array}$ & $\begin{array}{c}\text { Initial } \\
\text { effective } \\
\text { overburden } \\
\text { pressure, } \\
\mathrm{P}_{0}^{\prime} \\
\text { (psi) }\end{array}$ & $\underset{(\%)}{\left(\frac{\Delta \mathrm{H}}{\mathrm{H}}\right)}$ & $\begin{array}{c}\text { Settlement, } \\
\Delta \mathrm{H} \\
(\mathrm{ft})\end{array}$ \\
\hline 5 & 0 & 0 & 0.00 & 0.00 \\
\hline 10 & 5 & 6.25 & 0.40 & 0.02 \\
\hline 15 & 10 & 8.32 & 0.52 & 0.05 \\
\hline 20 & 15 & 10.4 & 0.64 & 0.10 \\
\hline 25 & 20 & 12.5 & 0.76 & 0.15 \\
\hline 30 & 25 & 14.6 & 0.87 & 0.22 \\
\hline
\end{tabular}

using the compression curves shown in Fig. E14 for wet or dry material, whichever is appropriate.

Settlements would also be expected due to vibratory loads from blast effects, earthquakes, more rapidly moving trains, or other heavy vehicles or equipment; however, estimating the magnitudes of settlements due to vibratory loads is beyond the scope of this report. 


\section{References}

1. D. Fitchett, Middle Course I Cratering Series, U.S. Army Engineer Waterways Experiment Station Explosive Excavation Research Laboratory, Livermore, Calif., Rept. NCG TR-35, June 1971.

2. C. Gardner and T. Shackleford, Project MINIMOUND, U.S. Army Engineer Waterways Experiment Station Explosive Excavation Research Laboratory, Livermore, Calif., Rept. EERO/TIM 71-10, March 1972.

3. K. Sprague, Middle Course II Crater Series, U.S. Army Engineer Waterways Experiment Station Explosive Excavation Research Laboratory, Livermore, Calif., Rept. TR E-73- (in preparation).

4. J. Lattery, Project TRINIDAD: Railroad Relocation, Cuts RR2 and RR3, U.S. Army Engineer Waterways Experiment Station Explosive Excavation Research Laboratory, Livermore, Calif., Rept. TR E-73-(in preparation).

5. R. Gillespie, Hole Springing, U.S. Army Engineer Waterways Experiment Station Explosive Excavation Research Laboratory, Livermore, Calif., Rept.

TR E-72-24, June 1972.

6. D. U. Deere, in Rock Mechanics in Engineering Practice (John Wiley \& Sons, New York, 1968), pp. 15-17.

7. D. Deere and R. Miller, Engineering Classification and Index Properties for Intact Rock, University of Illinois, Urbana, Ill., Rept. AFWL-TR-65-16, December 1966.

8. R. Bourque, Crater Data: A Computer Code for Analyzing Experimental Cratering Tests, U.S. Army Engineer Waterways Experiment Station Explosive Excavation Research Laboratory, Livermore, Calif., Rept. NCG/TM 70-15, October 1970.

9. B. Redpath, "A Concept of Row Crater Enhancement," in Engineering with Nuclear Explosives (Proceedings, American Nuclear Society Symposium, Las Vegas, Nev., January 1970, vol. 1, CONF - 700101, 1970).

10. S. Johnson, Explosive Excavation Technology, U.S. Army Engineer Waterways Experiment Station Explosive Excavation Research Laboratory, Livermore, Calif., Rept. NCG-TR-21, June 1971, pp. 16-18.

11. S. Johnson, ibid, Chapter 5 .

12. K. King, Project TRINIDAD, Delta Series Number 1, 2, and 3, Sopris, Colorado, U.S. Dept of Com., NOAA, National Ocean Survey, Special Projects Party, Las Vegas, Nev., Rept. CGS-746-9, December 1970.

13. T. Tami, Analysis of Ground Motion Peak Particle Velocities from Cratering Experiments at Trinidad, Colorado, U.S. Army Engineer Waterways Experiment Station Explosive Excavation Research Laboratory, Livermore, Calif., Rept. MP-E-73- (in preparation).

14. M. Kurtz and B. Redpath, Project Pre-GONDOLA, Seismic Site Calibration, U. S. Army Engineer Waterways Experiment Station Explosives Excavation Research Laboratory, Livermore, Calif., Rept. PNE 1100, May 1968. 
15. J. A. Blume and Assoc., San Francisco, personal communication (1971).

16. L. Vortman, Airblast from Project TRINIDAD Detonations, Sandia Corporation, Albuquerque, N. Mex., Rept. SC-RR-71 0056, June 1971.

17. B. D. Anderson, A Simple Technique to Determine the Size Distribution of Crater Fallback and Ejecta, U.S. Army Engineer Waterways Experiment Station Explosive Excavation Research Laboratory, Livermore, Calif., Rept. NCG-TR-18, March 1970.

18. A. D. Frandsen, Analysis and Reevaluation of Bulking Factors, U.S. Army Engineer Waterways Experiment Station Explosive Excavation Research Laboratory, Livermore, Calif., NCG/TM 70-1, March 1970.

19. M. G. Wolman, "A Method of Sampling Coarse River-Bed Materials," Transactions, American Geophysical Union, 35, 951-956 (1954).

20. N. D. Marachi, C. K. Chan, H. B. Seed, and J. M. Duncan, Strength and Deformation Characteristics of Rockfill Materials, University of California, Berkeley, Rept. TE-69-5, September 1969.

21. B. P. Walker and T. Whitaker, "An Apparatus for Forming Uniform Beds of Sand for Model Foundation Tests," Geotechnique 17, 161-167 (1967).

22. C. Snell and D. Oltmans, A Revised Empirical Approach to Airblast Prediction, U.S. Army Engineer Waterways Experiment Station Explosive Excavation Research Laboratory, Livermore, Calif., Rept. EERO TR-39, November 1971.

23. M. L. Silver and H. B. Seed, The Behavior of Sand Under Seismic Loading Conditions, Earthquake Engineering Research Center, University of California, Berkeley, Rept. EERC 69-16, December 1969.

24. R. J. Marsal, Discussion, Proceedings, 6th International Conference on Soil Mechanics and Foundation Engineering, Montreal 1965 (University of Toronto Press, Toronto, 1965) Vol. 3, pp. 310-316. 


\section{Distribution}

\section{LLL Internal Distribution}

Roger E. Batzel

L. S. Germain

M. A. Harrison

G. H. Higgins

A. Holzer

J. S. Kahn

V. N. Karpenko

J. B. Knox

C. A. McDonald

D. N. Montan

IM. D. Nordyke

H. L. Reynolds

J. W. Rosengren

R. W. Terhune

H. A. Tewes

J. Toman

G. C. Werth

LBL Library

TID File

External Distribution

E. Teller

University of California

Berkeley, California

HQDA (DAEN-CWZ-R)

Washington, D. C.

HQDA (DAEN-CWE-G)

Washington, D. C.

HQDA (DAEN-IMER-D)

Washington, D.C.

HQDA (DAEN-MCE-D)

Washington, D.C.

HQDA (DARD-MSN)

Washington, D. C.

U.S. Army Engineer Waterways Experiment Station

Vicksburg, Mississippi

U.S. Army Engineer Division, Huntsville

Huntsville, Alabama
U.S. Army Engineer District, Memphis

Memphis, Tennessee

U.S. Army Engineer District, New Orleans

New Orleans, Louisiana

U.S. Army Engineer District, St. Louis

St. Louis, Missouri

U.S. Army Engineer Division, Lower Mississippi Valley

Vicksburg, Mississippi

U.S. Army Engineer District, Vicksburg

Vicksburg, Mississippi

U.S. Army Engineer Division, Missouri River

Omaha, Nebraska

U.S. Army Engineer District, Kansas City

Kansas City, Missouri

U.S. Army Engineer District, Omaha

Omaha, Nebraska

U.S. Army Engineer Division, New England

Waltham: Massachusetts

U.S. Army Engineer Division, North Atlantic

New York, New York

U.S. Army Engineer District, Baltimore

Baltimore, Maryland

U.S. Army Engineer District, New York

New York, New York

U.S. Army Engineer District, Norfolk

Norfolk, Virginia

U.S. Army Engineer District, Philadelphia

Philadelphia, Pennsylvania

U.S. Army Engineer Division, North Central

Chicago, Illinois 
External Distribution (Continued)

U.S. Army Engineer District, Buffalo

Buffalo, New York

U.S. Army Engineer District, Chicago

Chicago, Illinois

U.S. Army Engineer District, Detroit

Detroit, Michigan

U.S. Army Engineer District, Rock Island

Rock Island, Illinois

U.S. Army Engineer District, St. Paul

St. Paul, Minnesota

U.S. Army Engineer Division, North Pacific

Portland, Oregon

U.S. Army Engineer District, Alaska

Anchorage, Alaska

U.S. Army Engineer District, Portland

Portland, Oregon

U.S. Army Engineer District, Seattle

Seattle, Washington

U.S. Army Engineer District, Walla Walla

Walla Walla, Washington

U.S. Army Engineer Division, Ohio River

Cincinnati, Ohio

U.S. Army Engineer District, Huntington

Huntington, West Virginia

U.S. Army Engineer District, Louisville

Louisville, Kentucky

U.S. Army Engineer District, Nashville

Nashville, Tennessee

U.S. Army Engineer District, Pittsburgh

Pittsburgh, Pennsylvania
U.S. Army Engineer Division, Pacific Ocean

Honolulu, Hawaii

U.S. Army Engineer Division, South Atlantic

Atlanta, Georgia

U.S. Army Engineer District, Charleston

Charleston, South Carolina

U.S. Army Engineer District, Jacksonville

Jacksonville, Florida

U.S. Army Engineer District, Mobile

Mobile, Alabama

U.S. Army Engineer District, Savannah

Savannah, Georgia

U.S. Army Engineer District, Wilmington

Wilmington, North Carolina

U.S. Army Engineer Division South Pacific

San Francisco, California

U.S. Army Engineer District, Los Angeles

Los Angeles, California

U.S. Army Engineer District, Sacramento

Sacramento, California

U.S. Army Engineer District, San Francisco

San Francisco, California

U.S. Army Engineer Division, Southwestern

Dallas, Texas

U.S. Army Engineer District, Albuquerque

Albuquerque, New Mexico

U.S. Army Engineer District, Fort Worth

Fort Worth, Texas

U.S. Army Engineer District, Galveston

Galveston, Texas 
External Distribution (Continued)

U.S. Army Eng ineer District, Little Rock

Little Rock, Arkansas

U.S. Army Engineer District, Tulsa

Tulsa, Oklahoma

U.S. Army Coastal Engineering Research Center

Washington, D. C.

U.S. Army Engineer Topographic Command

Washington, D.C.

U.S. Army Engineer Topographic Laboratories

Fort Belvoir, Virginia

U.S. Army Engineer Center

Fort Belvoir, Virginia

Commandant

U.S. Army Engineer School

Fort Belvoir, Virginia

NBC Division

U.S. Army Engineer School

Fort Belvoir, Virginia

U.S. Army Engineer Power Group

Fort Belvoir, Virginia
U.S. Army Engineer Training Center

Fort Leonard Wood, Missouri

Board of Engineers for Rivers and Harbors

Washington, D. C.

U.S. Army Cold Regions Research and Engr. Laboratory

Hanover, New Hampshire

U.S. Army Const. Engineering Research Laboratory

Champaign, Illinois

U.S. Army Corps of Engineer Waterways Experiment Station Explosive Excavation Research Laboratory, Livermore

TID-4500 Distribution, UC-35, Nuclear Explosions Peaceful Applications

NOTICE

"This report was prepared $\boldsymbol{m}$ an sccount of work sponsored by the United States Government. Nerither the Uniled States nor employees, nor any of their contractors, subcontractors, or their employees, makes ony werranty, express of implied, or os assumes eny legal linbility or responsibility for the accuricy, completenes

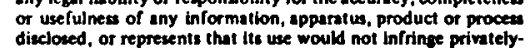
owned righis,"

Printed in U.S. A. Available from the National Technical Information Center, National Bureau of Standards

U. S. Department of Commerce, Springfield, Virginia 22151 Price: Printed Copy $\$ 3.00$; Microfiche $\$ 0.95$. 


\section{DOCUMENT CONTROL DATA - R \& D}

(Security classification of title, body of abstract and indexing annotation must be untered when the overall report is classified) 1. ORIGINATING ACTIVITY (Comorate euthor)

USAE Waterways Experiment Station Explosive

Excavation Research Laboratory

Project TRINIDAD - Explosive Excavation Tests in Sandstone and Shale

\section{DESCRIPTIVE NOTES (Type of roport and inclusive deter)}

Final Technical Report

5. AUTHOR(S) (First name, middlo inltial, last name)

Bruce B. Redpath

\begin{tabular}{|c|c|c|}
\hline $\begin{array}{r}\text { G. REPORT DATE } \\
\text { JUIY } 1972\end{array}$ & $\begin{array}{l}\text { 7E. TOTAL NO. OFPAGES } \\
\text { IOS }\end{array}$ & $\begin{array}{c}\text { 7b. NO. OF REFS } \\
24\end{array}$ \\
\hline $\begin{array}{l}\text { Ba. CONTRACT ORGRANT NO. } \\
\text { b. PROJECTNO. }\end{array}$ & $\begin{array}{r}\text { 9. ORIGINATOR'S REPOET } \\
\text { TR-E-73-1 }\end{array}$ & BERISI \\
\hline $\begin{array}{l}\text { c. } \\
\text { d. }\end{array}$ & $\begin{array}{l}\text { 9b. OTHEA REPOAT NO(S) } \\
\text { this report) }\end{array}$ & ther numbers that nay be as signed \\
\hline
\end{tabular}

10. DISTRIBUTION STATEMENT

Approved for public release; distribution unlimited.

\begin{tabular}{|l|l|l|}
\hline 11. SUPPLEMENTAFY NOTES & 12. SPONSORING MILITARY ACTIVITY \\
\hline
\end{tabular}

A series of single-, row-, and multiple-charge cratering detonations, with individual charge weights of one to two tons, were carried out in weak, interbedded sandstones and shales near Trinidad, Colorado, in 1970 and 1971. The principal. objectives of these excavation experiments were: to obtain single-charge cratering curves; to verify row-charge designs for achieving a specified excavation; to determine the effects of millisecond delays in row-charge cratering; to experiment with cratering in varying terrain; and to compare the cratering effectiveness of several explosives. Three varieties of aluminized ammonium-nitrate blasting. agents and ANFO were used. Airblast and seismic effects of each detonation were monitored. The series culminated with the excavation of a 400-foot long railway cut with 44 tons of explosives distributed among 32 charges. 


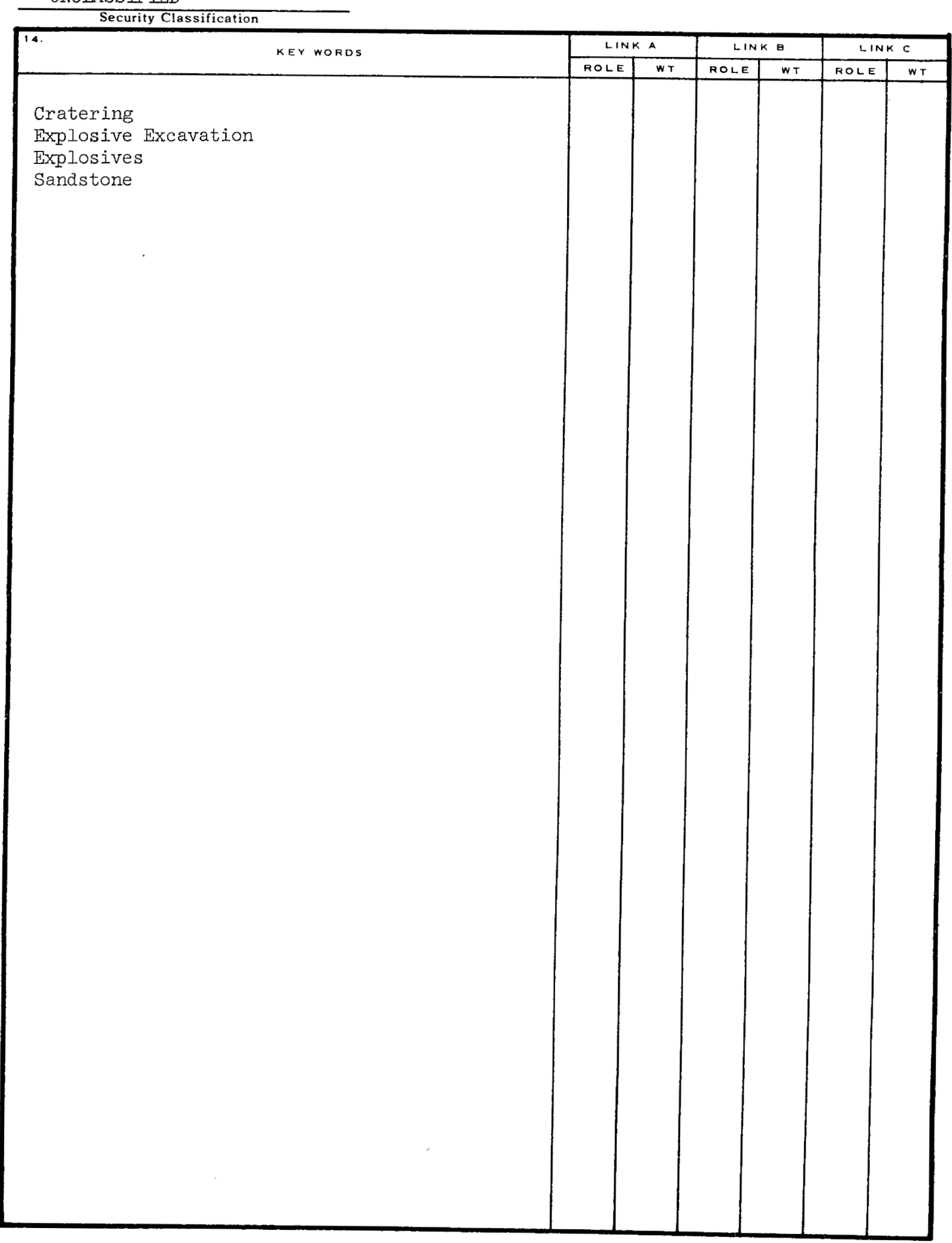

UNCIASS IFIED

Security Classification 
•

• 

-

- 


